


\section{MANAGING FOREST RESOURCES IN A DECENTRALIZED ENVIRONMENT Lessons Learnt from the Malinau Research Forest, East Kalimantan, Indonesia}

\section{Editors}

Petrus Gunarso, Titiek Setyawati, Terry Sunderland and Charlie Shackleton

\section{TECHNICAL REPORT OF ITTO PD 39/00 Rev. 3(F)}

Sustainable Collaborative Forest Management: Meeting the Challenges

of Decentralization in the Bulungan Model Forest 
This document has been produced with the financial assistance of ITTO, Ministry of Forestry Republic of Indonesia, CIFOR, District Government of Malinau-East Kalimantan, PT Inhutani II, DfID, BMZ, the John D. And Catherine T. MacArthur Foundation, the Ford Foundation and IRD.

Part of this document has been produced with the additional financial assisstance of EU and IFAD.

\section{Disclaimer}

The views expressed in this document can in no way be taken to reflect the official opinion of ITTO, Ministry of Forestry Republic of Indonesia, District Government of Malinau-East Kalimantan, PT Inhutani II, DfID, BMZ, the John D. And Catherine T. MacArthur Foundation, the Ford Foundation, IRD, EU and IFAD.

\section{Copyright 2007 CIFOR \& ITTO}

All rights reserved. No part of this publication may be reproduced, stored in a retrieval system, or transmitted, in any form or by any means (electronic, mechanical, photocopying, recording or otherwise) without the prior permission of the publishers.

Cover photos by Hari Priyadi, Eko Prianto and Ryan Woo

Graphic design and layout by Eko Prianto

Gunarso, P. et al. (eds.)

Managing forest resources in a decentralized environment: lessons learnt from the Malinau research forest, East Kalimantan, Indonesia/edited by Petrus Gunarso, Titiek Setyawati, Terry Sunderland and Charlie Shackleton. Bogor, Indonesia: Center for International Forestry Research (CIFOR), 2007.

ISBN: 978-979-24-4688-3

190p. (Technical Report of ITTO PD 39/00 Rev. 3(F))

$\mathrm{CABI}$ thesaurus: 1. natural resources 2. forest management 3. decentralization 4. local government 5. urbanization 6. forests 7. utilization 8. nature conservation 9. land use planning 10. reduced-impact logging 11. wildlife conservation 12. health 13. social change 14. East Kalimantan 15. Indonesia 16. research projects

Published by:

Center for International Forestry Research (CIFOR)

Jalan CIFOR, Situ Gede, Bogor Barat 16115

Indonesia

Tel.: +62 (251) 622622; Fax: +62 (251) 622100

E-mail: cifor@cgiar.org

Web site: http://www.cifor.cgiar.org

Mailing address:

CIFOR (Center for International Forestry Research)

P.O. Box 0113 BOCBD, Bogor 16000

Indonesia 


\section{TABLE OF CONTENTS}

ACKNOWLEDGEMENTS

FOREWORD

ACRONYMS AND ABBREVIATIONS

\section{CHAPTER 1}

INTRODUCTION

CHAPTER 2

TRADE-OFFS AND ALTERNATIVE LIVELIHOODS OF FOREST-DEPENDENT PEOPLE

IN THE MALINAU RESEARCH FOREST

CHAPTER 3

EXAMINING THE CONSERVATION SIGNIFICANCE OF LOCAL PEOPLES' PERCEPTIONS AND USES OF DIFFERENT FORESTED LANDSCAPES

CHAPTER 4

WILL FORESTS REMAIN IN THE FACE OF OIL PALM EXPANSION?

A SIMULATION MODEL FOR MALINAU, INDONESIA

\section{CHAPTER 5}

FACILITATING COOPERATION DURING TIMES OF CHAOS:

SPONTANEOUS ORDERS AND MUDDLING THROUGH IN MALINAU DISTRICT, INDONESIA

CHAPTER 6

INTERACTIVE LAND-USE PLANNING IN INDONESIA RAINFOREST LANDSCAPES:

RECONNECTING PLANS TO PRACTICE 


\section{CHAPTER 7}

REDUCED IMPACT LOGGING: BENEFITS AND CONSTRAINTS

CHAPTER 8

COMMUNITY-BASED FORESTRY AND MANAGEMENT PLANNING

CHAPTER 9

THE QUANTIFICATION AND USE OF WOOD WASTE

FOR COMMUNITY-LEVEL INCOME-GENERATION INITIATIVES

CHAPTER 10

WILDLIFE CONSERVATION IN BORNEAN TIMBER CONCESSIONS

\section{CHAPTER 11}

BACK TO THE TREES? DIET AND HEALTH AS INDICATORS OF ADAPTIVE RESPONSES TO ENVIRONMENTAL CHANGE: THE CASE OF THE PUNAN TUBU IN THE MALINAU RESEARCH FOREST

CHAPTER 12

TOWARDS SUSTAINABLE FOREST MANAGEMENT AND IMPROVED LIVELIHOODS IN TROPICAL FORESTS: LESSONS AND CONCLUSIONS 


\section{ACKNOWLEDGEMENTS}

CIFOR and FORDA, as the Project Executing Agencies and Project Implementing Agencies respectively, wish to thank ITTO, the Ministry of Forestry of the Republic of Indonesia, IRD, PT. Inhutani II, the District Government of Malinau, John D. and Catherine T. MacArthur Foundation, the Ford Foundation, WWF-Indonesia, Tropenbos International Indonesia Programme, LIPI, BIOMA, UNMUL, NC-IUCN, all Steering Committee members, and all partners and collaborators for their support in the execution of the project. We would also like to extend our gratitude to the people of Malinau who contributed significantly to the successful implementation of the project.

The editors wish to thank the following people who commented on this book in whole or in part: Carol Colfer, Edmond Dounias, Patrice Levang, Douglas Sheil and Eva Wollenberg. Two anonymous referees provide comprehensive and detailed comments and suggestions of the entire manuscript. 


\section{FOREWORD}

The devolution of forest management from central to provincial and district governments has been a dominant feature in national forestry sectors around the world in recent years.

In Indonesia, decentralization was implemented abruptly as part of many government reforms that marked the country's transition from the highly centralized control of the New Order regime to the democratic and decentralized government of today. Indonesia's experience with decentralization is evident in the name of the forest where the research was undertaken. The Bulungan Model Forest of the first phase had transformed into the Malinau Research Forest by the time the second phase of the ITTO project began in 2002, given there was a newly-created district.

The Bulungan Model Forest Project documented the decentralization process from just prior to the reform era, through the tumultuous reform years themselves, and on to the current post reform period. Forest governance was relatively chaotic, while also offering challenging opportunities to implement sustainable forest management at the district level of government.

During the second phase, the Malinau Research Forest Project implemented an approach based on integrated natural resource management (INRM), and included research on reduced-impact logging (RIL), community based forest management (CBFM), community health, and conflict resolution. The four years of research during this phase delivered a broad array of outcomes, especially in the area of balancing the national and local development role of forests with their important conservation and environmental service roles.

The invitation to link the Malinau forests with the international network of Model Forests along with the local government's decision to declare Malinau as a Conservation District, are all indicators of the positive ancillary impact of the project has had on the district. It is all the more significant when considered in terms of what has happened in other districts where local governments often seek income through the short term extraction of natural resources, rather than looking towards the longer term sustainable provision of environmental services. 
A range of indicators, including stakeholder and communication surveys, suggest the project has been successful in communicating and restituting results to local stakeholders. There is enhanced awareness among local government officials of the unique and abundantly rich forest environments around them.

During Phase II of the project, Indonesia's highest environmental prize, the Kalpataru Award, was given to the village of Setulang. It is perhaps no coincidence that of the many villages the project worked with, nowhere was this partnership more strong than with Setulang. The project's longterm presence in Malinau has been strongly supported by the district head and regent, Dr. Marthin Billa, who has also been awarded the Kalpataru Award in recognition for his efforts to establish Malinau as a conservation district. Dr. Billa was also honoured by the Biodiversity Foundation for his commitment to environmental protection and wise management of Malinau. Formal recognition of the projects activities will help to ensure the future of Malinau will be in the secure hands of an aware and committed local government.

The findings from the many years of research in Malinau are still being produced, processed and peer reviewed. It is anticipated both district officials and villagers living in more than 27 forest communities have benefitted and will continue to benefit from the project's activities. These benefits will include the provision of relevant information that enhances local awareness of the importance of sustainable forest management and contributes to improved coordination at the district level of government on the issue.

The second phase of the project has increased awareness among researchers and similar stakeholders of the challenges on the ground and general agreement that more intervention is needed. The project's action research model has demonstrated the effectiveness of development interventions. This approach is expected to improve and develop with increased participation from the Ministry of Forestry's Research and Development Agency (FORDA) and from the Malinau district government. Future phases of the project, with or without external support, will see greater engagement from local officials in the project and eventually see the local government taking the lead in intervention.

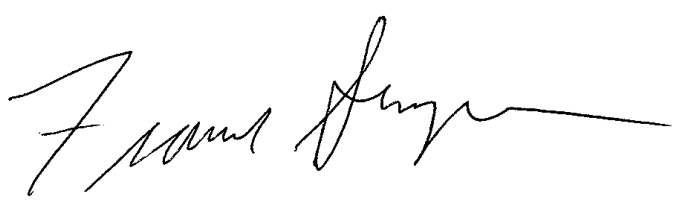

FRANCES SEYMOUR

Director General

Center for International Forestry Research (CIFOR)

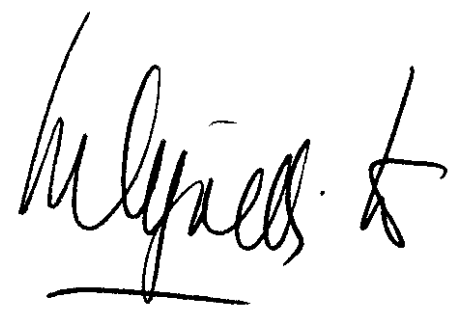

Ir. WAHJUDI WARDOJO, MSc

Director General

Forestry Research and Development Agency (FORDA), Ministry of Forestry, Indonesia 


\section{ACRONYMS AND ABBREVIATIONS}

$\begin{array}{ll}\text { ACM } & \text { Adaptive Co-Management } \\ \text { asI } & \text { Above sea level } \\ \text { BA } & \text { Basal area } \\ \text { BMI } & \text { Body Mass Index } \\ \text { BPS } & \text { Badan Pusat Statistik (Central Bureau of Statistics) } \\ \text { CBFM } & \text { Community-Based Forest Management } \\ \text { CIFOR } & \text { Center for International Forestry Research } \\ \text { CDM } & \text { Clean Development Mechanism } \\ \text { dbh } & \text { Diameter at Breast Height } \\ \text { FAO } & \text { Food and Agriculture Organization } \\ \text { FORDA } & \text { Forestry Research and Development Agency } \\ \text { GIS } & \text { Geographic Information System } \\ \text { GPS } & \text { Global Positioning System } \\ \text { ha } & \text { Hectare } \\ \text { IHH } & \text { luran Hasil Hutan (Forest Product Royalties) } \\ \text { IHPH } & \text { luran Hak Pengusahaan Hutan (Forest Concession License Fee) } \\ \text { INHUTANI } & \text { Eksploitasi dan Industri Hutan (Forest Exploitation and Industries), } \\ & \text { a name of the State-owned forest enterprise active in Malinau } \\ \text { INRM } & \text { Integrated Natural Resource Management } \\ \text { IPPK } & \text { ljin Pemungutan dan Pemanfaatan Kayu (Wood Utilization and Harvesting Permit) } \\ \text { IRD } & \text { Institut de Recherche pour le Développement } \\ \text { ITTO } & \text { International Tropical Timber Organization } \\ \text { IUCN } & \text { International Union for Conservation of Nature and Natural Resources, } \\ & \text { now known as the World Conservation Union } \\ \text { K } & \text { Potassium } \\ \text { LIPI } & \text { Lembaga Ilmu Pengetahuan Indonesia (The Indonesian Institute of Sciences). } \\ \text { MLA } & \text { Multidisciplinary Landscape Assessment } \\ \end{array}$




$\begin{array}{ll}\text { MOF } & \text { Ministry of Forestry } \\ \text { MRF } & \text { Malinau Research Forest } \\ \text { NGO } & \text { Non-Governmental Organization } \\ \text { NRM } & \text { Natural Resources Management } \\ \text { NTFP } & \text { Non Timber Forest Product } \\ \text { P } & \text { Phosphorus } \\ \text { PAR } & \text { Participatory Action Research } \\ \text { PES } & \text { Payments for Environmental Services } \\ \text { PFM } & \text { Participatory forest management } \\ \text { PSP } & \text { Permanent sample plot } \\ \text { QFCS } & \text { Quantitative food consumption survey } \\ \text { RIL } & \text { Reduced-Impact Logging } \\ \text { Rp } & \text { Indonesian Rupiah } \\ \text { SD } & \text { Standard Deviation } \\ \text { SFM } & \text { Sustainable Forest Management } \\ \text { SPSS } & \text { Statistical Packages for the Social Sciences } \\ \text { TFF } & \text { Tropical Forest Foundation } \\ \text { TPn } & \text { Tempat Penimbunan Kayu Sementara (temporary log landing) } \\ \text { TPTI } & \text { Tebang Pilih dan Tanam Indonesia (Indonesian Selective Logging } \\ & \text { and Planting System) } \\ \text { WWF } & \text { World Wide Fund for Nature }\end{array}$





\section{CHAPTER 1 INTRODUCTION}

THE MALINAU RESEARCH FOREST: AN OVERVIEW

Petrus Gunarso 
The district of Malinau lies in the 'heart of Borneo". The district is comprised of over 90\% forest and represents the largest remaining contiguous area of Dipterocarpus forest in south-east Asia. Most of the district's 40,000 inhabitants practise swidden agriculture and hunting and gathering from the forest. They include more than 20 ethnic groups, including the largest group of Punan hunter-gatherers in Borneo. The district includes a significant portion of the Kayan Mentarang National Park and has high conservation value for plants and animals. As all forest lands are under the control of the state, timber concessions allocated through previous central governments, based in Jakarta, control the rights to timber. However, the district government has challenged these rights by allocating its own permits for timber harvesting and by changing land-use plans. Most accessible lowland forests are now degraded as a result of logging and extensive swidden cultivation. The interactions between the need for both conservation and development of the area, underpinned by the complex political and administrative systems present in Malinau, are representative of the conditions that characterise many such landscapes in the tropics. Hence the findings of integrated and focused research in such regions has considerable wider application.

Since the start in 1997 of the first phase of the International Tropical Timber Organization (ITTO) project 'Forest, Science and Sustainability: the Bulungan Model Forest', Indonesia has been through tremendous changes. The Asian financial crisis in the second half of 1997 and the social and political turmoil of 1998 put an end to more than 30 years of General Suharto's dictatorship. The implementation of regional autonomy, or decentralisation, starting in 2000 and the division of the district of Bulungan into three new districts has had a tremendous impact on the local economy.

Meeting the challenges of decentralisation in forest management is a pertinent contemporary issue faced by the Republic of Indonesia and many other countries. The Phase II project of the Bulungan Model Forest, funded mainly by ITTO, in collaboration with a number of partners, has highlighted the wide-ranging implications of decentralisation faced by the district of Malinau in East Kalimantan. The shifting power balance between the central, provincial and district governments has been clearly reflected in the management of forest resources of the Malinau District. The issues described in this book, although focusing on a single district, are relevant to the problems faced by the whole of Indonesia in the sustainable management of forest resources in more than 400 districts that recently received autonomous authority for land management through the process of decentralisation.

The Bulungan Model Forest, as initially described in the ITTO Project PD 39/00 Rev. 3(F), has been transformed into the 'Malinau Research Forest', and this is the term used throughout this book. The transformation included not only a change in name, but also a change in scope (agreed to by the Project Steering Committee in the early stages of the implementation of Phase II of the project). There were at least three reasons why the project had to expand its coverage. Firstly, the former name of Bulungan Model Forest created confusion for stakeholders, particularly after the year 2000 when the Bulungan District was divided into three new districts, with the main research area now falling in the Malinau District, not Bulungan District. The new name of Malinau Research Forest meant that stakeholders more clearly understood the location. The second reason is related to the area $(302,000$ ha) officially designated by the government of Indonesia for longterm forest-based research by CIFOR. This area became loosely known as Bulungan Model Forest, yet the bulk of the research was not conducted within this area as the official area was exceptionally remote. The project covered research not only on logging and forest management, but also wider aspects of poverty, health, livelihoods and social aspects of forest management. Such studies are better conducted outside the officially designated research area, given the limited number of people in the official area. Thirdly, it is useful to cover the entire district if one is to address the challenges of decentralisation. The smallest unit of administrative governance, based on the existing decentralisation law, is the district. It is more appropriate therefore to address the impact and challenges of decentralisation at this district level, rather than in a given small part of the district. Furthermore, given that the project aims to provide a model that can be used in other districts, it is more appropriate to focus at the district level rather than a more limited area. 
The work undertaken in the Malinau Research Forest attempts to take an integrated natural resources management approach. The overall goal of the project was to identify management options that achieve a balance between development and conservation at the district level of government which is the new autonomous working unit created by the decentralisation process. The objective was to provide solutions to the challenges faced by the implementation of decentralisation policies in Indonesia. The project aimed to achieve longterm forest management for multiple uses, integrating social, economic, environmental and silvicultural considerations.

The research dealt with a wide variety of stakeholders and attempted to provide practical tools, guidelines on issues related to land use, alternative livelihood opportunities, biodiversity information, alternative economic options, training and capacity building, information sharing and practical management options. These research issues and topics form the basis of the information presented in this book.

\section{THE SCOPE OF THIS BOOK}

This book consists of twelve chapters, the majority of which are multi-authored, indicating the multi-institutional and multi-disciplinary nature of the research teams. Chapter Two by Patrice Levang and his co-workers explores the multifaceted use of the forest and its resources by the Punan and how increased urbanisation is influencing their relationship with the forest. Local perceptions of forest utilisation and conservation are explored in detail by Sheil et al. in Chapter Three which addresses the current perception, particularly pertinent in a decentralised environment, that conservation is driven mainly by 'outsiders'. Visioning work by Suwarno et al. is presented in Chapter Four and explores the economic options in the district using a scenario-building approach, focusing specifically on the replacement of high forest with oil palm plantations. In Chapter Five Wollenberg et al. describe efforts at establishing adaptive management models, working with villagers and government officials in Malinau where a weak, uncertain institutional setting and complex shifting political landscape arguably makes formal cooperation among these groups problematic. Land-use planning in Malinau is discussed in detail in a second paper by Wollenberg et al. in Chapter Six and shows how the current paradigm of centralised non-participatory planning is not well-suited to many forest areas. As such, an alternative approach based on lessons learned during five years of action research on integrated land-use planning in Malinau is presented. In Chapter Seven, Priyadi et al. summarise a large body of work on the effects of reduced impact logging (RIL) on the residual forest stand and discusses the reasons why RIL techniques are slow to be adopted by logging companies despite the apparent benefits. Limberg et al. in Chapter Eight expand the discussion surrounding local planning processes using two community-based examples. The benefits and potential economic value of wood waste from logging activities are elaborated by Iskandar et al. in Chapter Nine. The impacts of logging on wildlife by Meijaard and Sheil in Chapter Ten highlights how resilient some species are to timber extraction, the implications for sustainable forest management, and how some species are more susceptible to forest disturbance and require a focused management approach. Forest and health issues are discussed by Dounias et al. in Chapter Eleven where the effect of social change and increased sedentarisation on the diet and the health of former hunter-gatherers are assessed using a comparative and quantitative study of the changing dependency on forest resources of Punan living upstream in remote villages, versus Punan now resettled in the district head city of Malinau. Chapter Twelve provides a more detailed summary of the findings of the research carried out in Malinau and provides guidelines on lessons learned and the potential for the 'scaling-up' effects of the research activities carried out.

\section{GENERAL SITE DESCRIPTION OF THE MALINAU RESEARCH FOREST ${ }^{1}$}

\section{Introduction}

The Malinau District is one of the extension districts of Bulungan District, which is designated

\footnotetext{
${ }^{1}$ A more detailed site description has already been published by Machfudh (2002)
} 
by Ministerial Decree (Act no. 47/1999). The District covers an area of $42,260 \mathrm{~km}^{2}$, and is the largest in the Province of East Kalimantan. Geographically, the Malinau District is located between $1^{\circ} 21^{\prime} 36^{\prime \prime}$ and $4^{\circ} 10^{\prime} 55^{\prime \prime}$ North, and between $114^{\circ} 35^{\prime} 22^{\prime \prime}$ and $116^{\circ} 50^{\prime}$ 55" East. The area is adjacent to the Kayan Mentarang National Park where the World Wildlife Fund for Nature (WWF) is supporting the Ministry of Forestry in conservation management as part of a long-term initiative. The Malinau District and the National Park cover an expanse of more than 1.7 million ha of continuous forest and lie at the heart of one of Asia's last remaining areas of tropical forest.

\section{Climate}

The climate in Malinau District is categorised as tropical humid, with annual rainfall ranges between $2,500-\geq 4,000 \mathrm{~mm}$. The dry period is less than two months in duration and the wet season is more than nine months long. The mean annual temperature is $27^{\circ} \mathrm{C}$, with $5-7^{\circ} \mathrm{C}$ diurnal temperature differences. The maximum temperature $\left(32-48^{\circ} \mathrm{C}\right)$ occurs between April and October. The relative humidity is high, ranging from $75 \%-98 \%$.

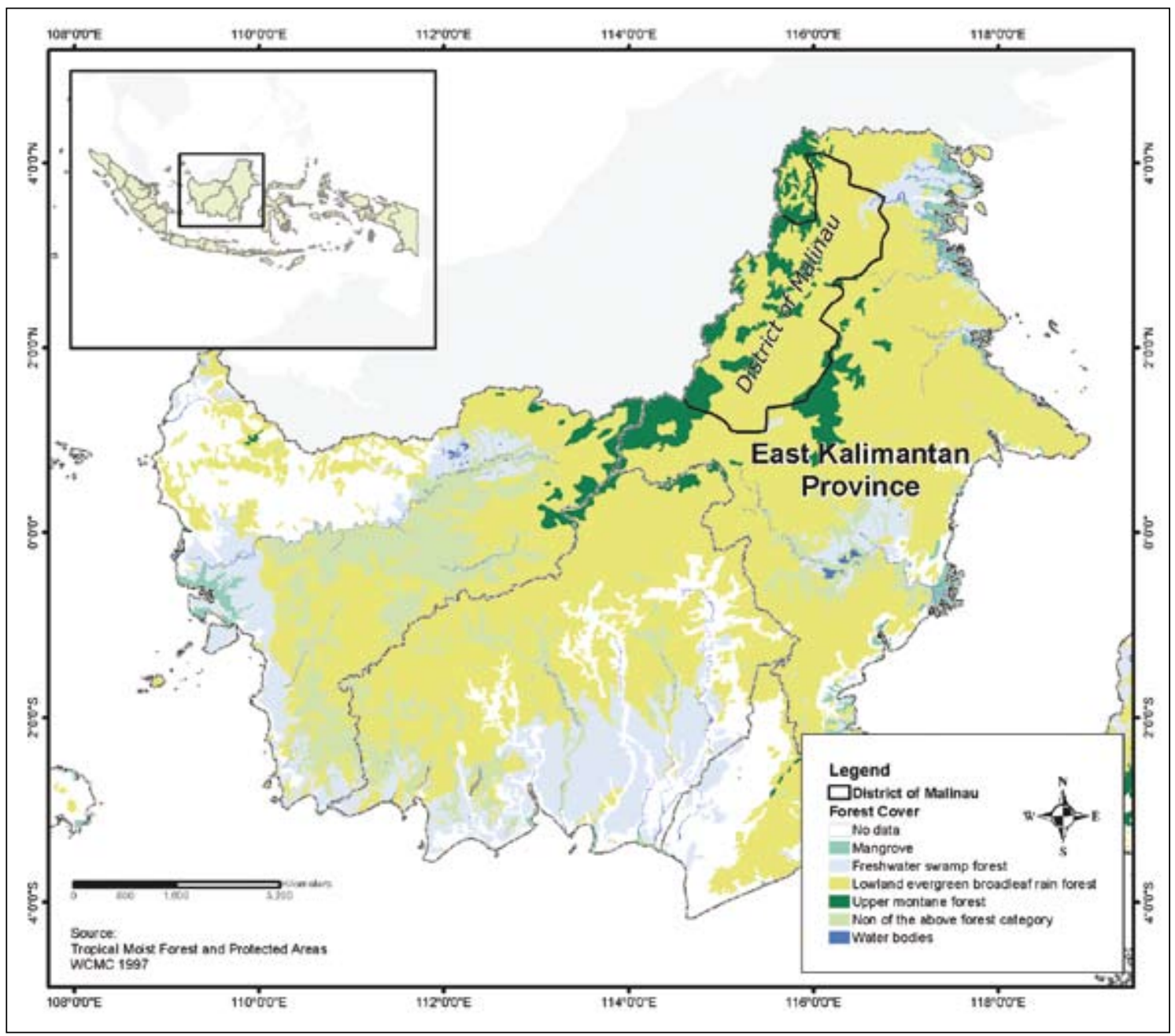

Figure 1. District of Malinau, Indonesian Borneo 


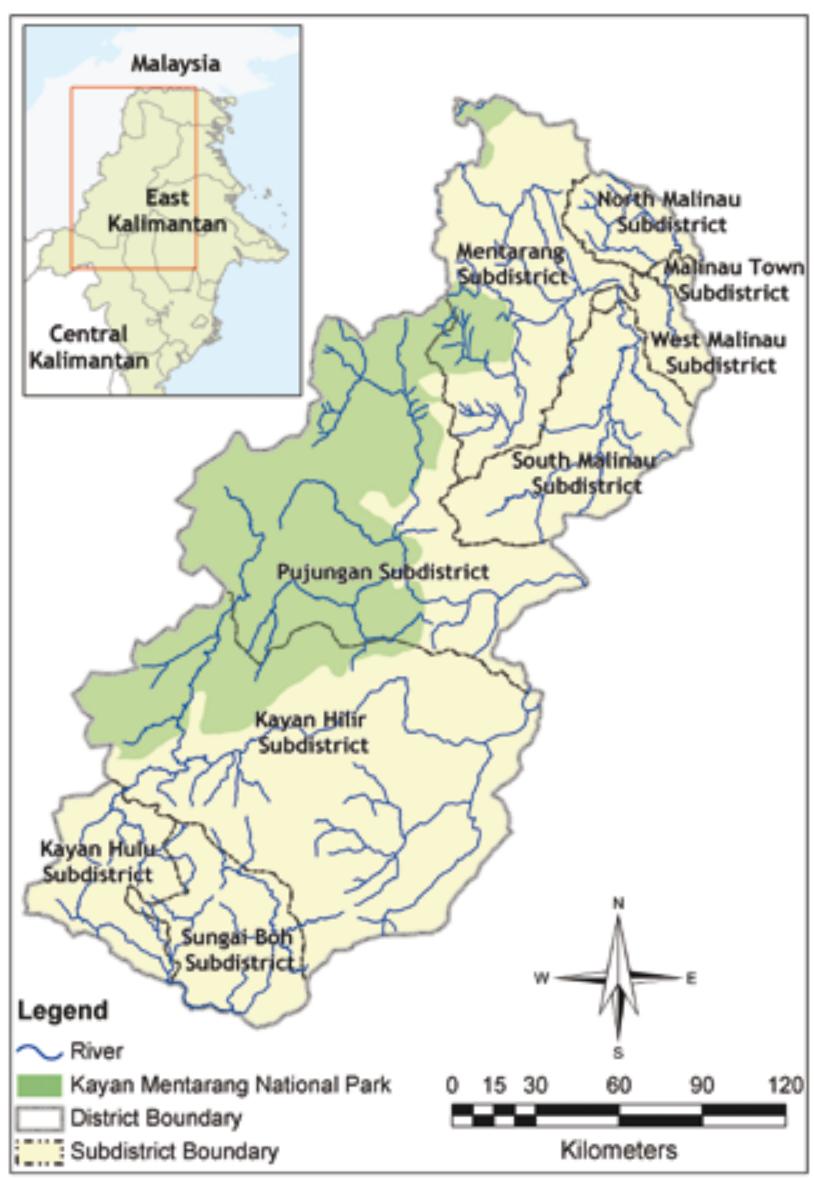

Figure 2. Malinau District showing sub-districts and Kayan Mentarang National Park

\section{Topography and Physiography}

The topographic characteristic of Malinau District is rugged throughout, with $84 \%$ of the area being classified as mountainous with an altitudinal range of about $100 \mathrm{~m}$ a.s.l. to almost 2,000 $\mathrm{m}$ a.s.l. (Machfudh, 2002). The most strongly dissected terrain is located on the south-western and western sides. Lowlands lie along watersheds such as the Malinau, Simendurut, Sembuak and Salap rivers, and these lowlands are comprised of fertile alluvial plains. However, the majority of the Malinau District area is composed of highlands and high-altitude plateaux, much of which remains forested.

\section{Hydrology}

Three main rivers run across the Malinau District. The Malinau River flows from west to east and then turns to the north. The Tubu River runs from the middle section of the district to the north to meet the Mentarang River which, in turn, joins the Malinau River at Pulau Sapi. The third major river is the Bahau River, located on the western side of the district, flowing from north to south where is merges with the Kayan River. Based on this pattern of river flow, the district may be divided into three main drainage blocks or watersheds: the Malinau (44\%), Tubu/Mentarang (36\%) and the Bahau (20\%). The longest river in the district is the $622 \mathrm{~km}$ Bahau River.

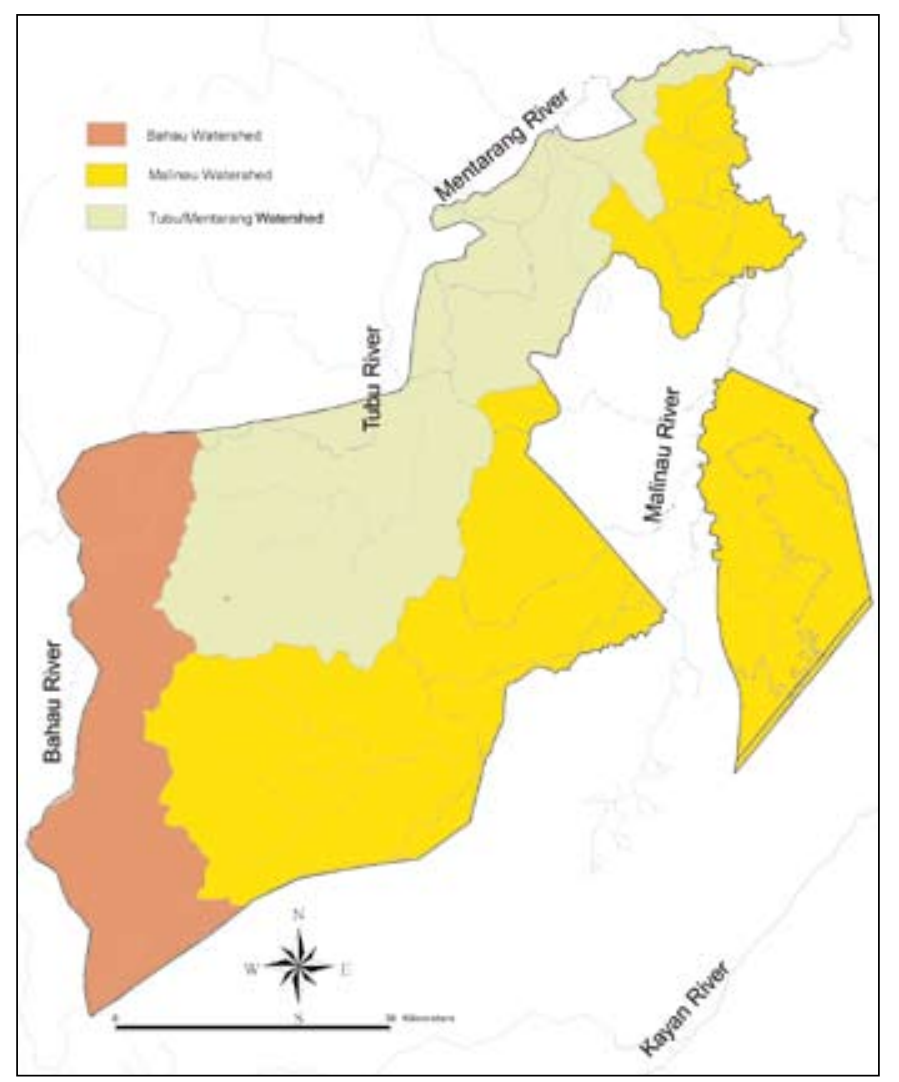

Figure 3. The main watersheds of formally called "Bulungan Research Forest"

\section{Geology}

The Malinau District area posseses a wide range of geomorphological characteristics. The main geological formations include volcanic, metamorphic and sedimentary rock with extensive alluvial deposits. The lowlands are composed of alluvial swamps, e.g. at Malinau Subdistrict and its surrounding areas, while the morphology of the undulating landscape is composed of sandstone, loamy stone and other types of unsolid stones. At higher altitudes, the rough and steep undulating landscape is usually 
composed of old sediment stones which are formed through the processes of rising, folding and continuous land movement.

\section{Soils}

The majority of the soils in the Malinau District have developed on rolling plains and dissected hills, on sedimentary and on old igneous rock formations. The soil type in Malinau District is dominated by inceptisol type which is usually characterised by low fertility and a high susceptibility to erosion. Such soils possess low fertility because they originate from acidic sediment stones and high rainfall in the area has caused significant base leaching.

\section{Forests and vegetation}

The lowland forests of the island of Borneo are of global importance for their high species richness and endemism (Bryant et al., 1997). Approximately $34 \%$ of all plant species, 37 species of bird and 44 land mammals are endemic to the island (MacKinnon et al., 1996). The diversity of fish (Rachmatika et al., 2005) and reptiles and amphibians (Meijaard et al., 2005) are also high in East Kalimantan. It is therefore imperative to develop appropriate strategies for conserving this rich biological diversity, particularly in the lowland forest formations. A more extensive description of the biodiversity of the Malinau Research Forest is provided in Sheil (2002) and Meijaard et al. (2005). The forests are classified as follows:

Lowland Dipterocarp forests: This is the most extensive forest type in the Malinau District and is estimated to cover about $98.4 \%$ of the total area (Machfudh, 2002). This forest formation is characterised by individual trees that may reach heights of between $35-45 \mathrm{~m}$. The family Dipterocarpaceae dominate the species composition of all trees $>10 \mathrm{~cm} \mathrm{dbh}$ and the Dipterocarp forests of Kalimantan are probably the last remaining forest formation of this type in south-east Asia.

Submontane forest: This forest, occurring at altitudes $>1,500 \mathrm{~m}$, covers a relatively small area (approx. $0.44 \%$ ) of the Malinau District. There are many more individual trees per hectare in this formation, most of which have a relatively small diameter.
Riparian forest: This forest formation is confined to the immediate vicinity of the river banks, mainly in the north-western part of the Malinau District and is dominated by Dipterocarpus oblongifolius. The forest is periodically flooded when rivers overflow during heavy rains.

Alluvial forest: Occurring primarily in low-lying areas and in flood plains, this forest covers a relatively small area. A number of species of Dipterocarpaceae characterise this forest formation.

\section{Socio-economic characteristics}

The majority of the district's 40,000 residents are concentrated in the district capital, Malinau town, with the remaining 15,000-20,000 people living in the forested parts of the district. The indigenous people of the Malinau District, particularly in the Malinau and Tubu watersheds, consist of several entholinguistic groups, including the Merap, Punan, Kenyah, Putuk and Abai (Machfudh, 2002; see also Levang et al., this volume). In general, the ethnically indigenous groups are reliant on natural resources and are essentially agriculturalists, practising swidden cultivation of upland rice, hunter-gathering and collection of non-timber products from the forest. The largest ethnic group is the Punan, who inhabit around $30 \%$ of the villages of the district, or $17 \%$ of the total population. The Punan are best known as being primarily hunter-gatherers.

Other groups, such as the Muslim Dayak, live outside the forest boundary, closer to the town of Malinau, and rely on other forms of economic activity, such as trading and more extensive agriculture. Due to the policy of tranmigrasi, there is also a small population of immigrants from other areas of Indonesia, particularly those of Buginese origin.

The total population of Malinau District in 2006 was 56,153 people distributed in 112 villages and 12 subdistricts. The most populated area is Malinau Kota Subdistrict which accommodates $70 \%$ of the total population. The majority of the population is Protestant $(57 \%)$ and the rest are Muslim (21\%), Catholic (18\%) and Buddhist (4\%). 


\section{Land tenure}

Two types of land rights are recognised in Malinau: individual holdings and community land. Individual holdings come from land from which the products are for family consumption only. Each household has around the same size of individual holding which is allocated by the community organisation (lembaga adat), headed by a community leader. Individual holdings are, on average, around 1-2 ha per household for short-term farming and around $0.2-1.0$ ha for long-term agricultural use.

Community-allocated land is referred to as Tanah Ulen. As village-owned forest land, Tanah Ulen is protected and managed cooperatively for the common interest of the villagers. This land provides a source of supply or a storage place for reserves for meeting the needs of the village people such as wood for construction, NTFPs and animals for hunting.

\section{Land Cover}

Forests an area of 3,969,360 ha, representing $90.4 \%$ of Malinau land cover . The breakdown of forest area based on its utilisation classification is as follows:

Protection forests: 625,481 ha

Production forests: 529,809 ha

Limited Production Forests: 1,415,309 ha

Kayan Mentarang National Park: 977,325 ha

Other Utilisation areas: 421,436 ha

Hence forestry utilisation in Malinau District covers over an area of $\pm 1,980,510$ ha, although the total forest area where the eight forestry companies operate currently covers about $1,132,229$ ha. Forest exploitation activities conducted in Malinau are mostly classified as limited production forest (HPT). All of the forestry companies must have a permit issued by Ministry of Forestry.

\section{Administration}

After 32 years of repressive authoritarian rule, the fall of the Suharto regime in May 1998 initiated a surge of dramatic political reforms and uncertainty throughout Indonesia. Policy reforms gave more control to district governments, including the right to reap more benefits from local economic activities and for people to choose their own representatives. Reforms decreased government censorship and intimidation and allowed people to protest and address conflicts more openly. Widespread euphoria about the possibilities for more democracy resulted, but so did widespread confusion, as most institutions were not yet ready for the new rights and responsibilities thrust upon them.

Forest-rich parts of Indonesia, such as Malinau, experienced enormous instability during these reforms. Local governments suddenly had opportunities to capture timber profits that had previously gone to the central government and concession holders. The districts immediately mobilised small-scale timber harvesting in their areas (Limberg et al., this volume). From April 2000 to August 2001, the Malinau District issued 46 cutting permits granting access to more than 60,000 ha. At the same time, local communities felt empowered to make claims to forest land and to demand compensation for damages. Confusion about the classification of land functions and conflict over claims to forest land increased exponentially between 2000 and 2002. The central government made numerous attempts to stop logging. With the passage of a regulation in 2002, the Ministry of Forestry made the district cutting permits illegal.

\section{REFERENCES}

Bryant, D. D. Nielsen and Tangley, L. 1997. The last frontier forests: ecosystems and economies on the edge. World Resources Institute, Washington DC.

Machfudh. 2002. General description of the Bulungan Research Forest. In: pp. 8-22. Technical Report Phase I, 1997-2000 ITTO Project PD 12/97 Rev. 1 (F). CIFOR, Bogor, Indonesia.

MacKinnon, K., Hatta, G., Halim H. and Mangalik, A. 1996. The ecology of Kalimantan. Periplus Edition.

Meijaard, E., Sheil, D., Nasi, R., Augeri, D., Rosenbaum, B., Iskandar, D., Setyawati, T., Lammertink, A., Rachmatika, I., Wong, A., Soehartono, T., Stanley, S., O’Brien, T. 2005. Life after logging: reconciling wildlife 
conservation and production forestry in Indonesian Borneo. CIFOR, Bogor, Indonesia.

Rachmatika, I., Nasi, R., Sheil, D., Wan, M. 2005. A first look at the fish species of the middle Malinau: taxonomy, ecology, vulnerability and importance. CIFOR, Bogor, Indonesia.
Sheil, D. 2002. Biodiversity research in Malinau. In: pp. 57-107. Technical Report Phase I, 1997-2000 ITTO Project PD 12/97 Rev. 1 (F). CIFOR, Bogor, Indonesia. 


\section{CHAPTER 2 \\ TRADE-OFFS AND ALTERNATIVE LIVELIHOODS OF FOREST-DEPENDENT PEOPLE IN THE MALINAU RESEARCH FOREST}

Patrice Levang, Soaduon Sitorus, Darif Abot and Dollop Mamung 


\section{INTRODUCTION}

The district of Malinau hosts one of the largest remaining populations of hunter-gatherers in Asia, the Punan. All forest-dependent people of the district have been faced with the many changes - political, social and economic - since the district was created. But all did not experience the changes in the same way. For people living close to the district capital of Malinau, the changes have been considerable. For people living in remote upstream areas, little has changed.

The main results from the Phase 1 study (Levang, 2002) showed that people's dependencies on forests in the Malinau District were multifaceted. In the most remote areas, such as the Upper Tubu and the Pujungan watershed, people were occasionally depending on wild sago palm for their subsistence needs. For bridging the gap between two rice harvests, swidden cultivators generally count on cassava. But when yields are especially low and when people run out of cassava, resorting temporarily to sago starch is the only way out of famine for cash-strapped families. Wild game and fish remain important sources of protein, and other forest products such as vegetables and fruit also provide important complementary items to the diet of the forest people.

Local people can name hundreds of useful plants or animals. Most of these products, such as rattan or resins, are available in large quantities in surrounding swiddens and forests. However, the range of tradable products remains very limited. Historically, birds' nests played a determining role in initiating the trade of forest products on the eastern coast of Kalimantan. Nowadays the product is still highly prized but only very few families control birds' nest caves. Eaglewood (Aquilaria spp.), or gaharu, remains without doubt the main cash-earning forest product for local people, especially in remote areas. Closer to town, game and fish recently became tradable products. Yet in traditional hunter-gatherer communities game is usually distributed among all village members. Much to the resentment of elderly people, this tradition is no longer upheld in settlements closer to towns.
Access to the market is clearly one of the most limiting economic factors. In the Upper Tubu catchment even intrinsically valuable products such as coffee or timber have no market value because of the poor accessibility of the area. For instance, in Long Titi village the transportation cost of coffee from the village to the banks of the Tubu River exceeds the price of the coffee beans in Malinau. Good quality timber is still available in large quantities in the upper reaches of the watersheds. However, the absence of transportation means this timber is not yet exploitable.

Local people depend even more on traders than on markets. Forest people can organise short collecting trips to nearby forests but these areas are already overexploited. In order to organise a three week gaharu collecting trip, the gatherers need the help of a trader. The trader provides the cash advance necessary for the collectors and their families (Kurniawan, 2003). In the case of a monkey hunt for bezoar stones ${ }^{1}$, the trader also provides the shotgun cartridges required. In remote upstream areas the trader is generally the only contact forest people have with the outside world. As a rule, where traders are no longer active, economic activity is at a standstill.

Local people also depend on forests for swidden cultivation. Opening a swidden every year is one of the ways of working towards food selfsufficiency (although not always attained). Even in accessible areas, most households manage to produce at least part of their staple food. Agricultural production serves as insurance, a safety net against low success during gaharu collecting trips. With the increase in district population, fallow lengths tend to decline and households are eager to open new upland rice swiddens (ladangs). Nowadays preferred areas are located along the main connecting roads, for instance between Long Loreh and Malinau.

Since the end of the Suharto era, local people gained partial control of their forests. Concessionaires such as logging and coalmining companies can no longer exploit timber and coal without the approval of local

\footnotetext{
1 A bezoar stone or enterolith is a sort of calculus or concretion found in the intestines of some animals. Bezoar stones are much sought after in Chinese pharmacopoeia.
} 


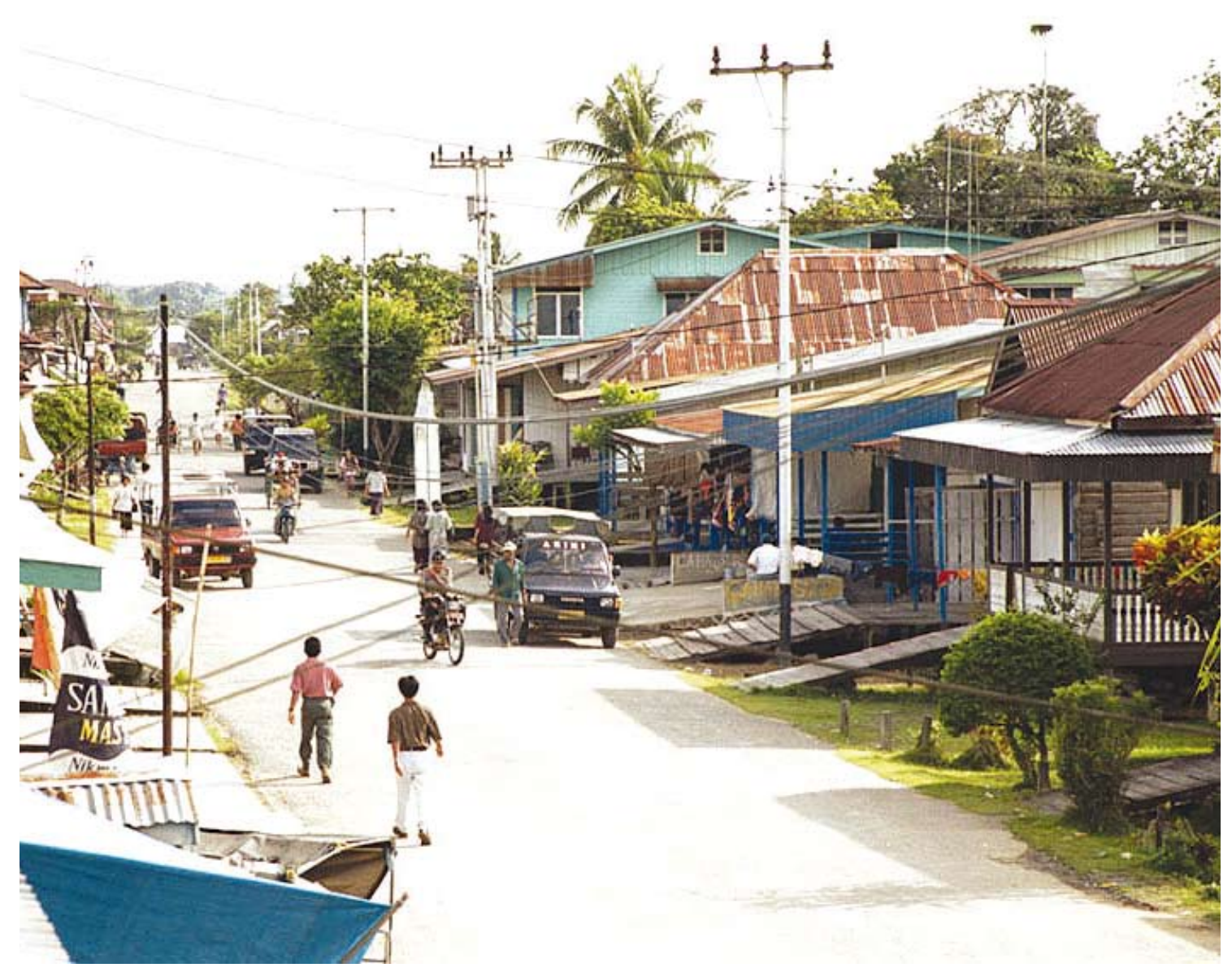

Living in the city of Malinau means good access to services and markets (Photo by Patrice Levang)

communities. However, communities still depend on the concessionaires for fulfilling administrative prerequisites, for road building, production and shipping, and claiming of fees or royalties from the concessionaires for them to be allowed to exploit natural resources in the areas they controlled.

Local people are becoming increasingly dependent on outside goods and services. Owning a long-tail engine or an outboard engine is crucial for somebody living in a remote village. Clearing a ladang without a chainsaw is no longer considered an option. Televisions and video players are now a family's basic electronic equipment. People's desire for quality educational and health services is rarely met by government projects in remoter areas. Thus, the wealthier community members do not hesitate to send their children to far-away schools in Malinau, Tarakan or Samarinda. As village dispensaries are seldom well-equipped, people do not hesitate to go to Malinau or Tarakan for medical care. For all these reasons, forest people are increasingly dependent on cash, and for the time being, the forest and its products (timber and non-timber products) are the principal or only means to derive the required finance.

The main result of our research during Phase 1 was that indeed forest people were dependent on forests and forest products for their livelihood. However, this dependency shifted over time from a dependency on forests for subsistence needs, to a dependency on forests for cash needs. This parallels findings in other parts of the world (see Shackleton, 2005). Moreover these cash needs are rapidly increasing and, as a corollary, ways of life are evolving. Torn between their desire to preserve their hunting grounds and the need to sell their forests to satisfy increasing needs for cash, local people are all but ready to resolve this contradiction at the expense of the forest. 
Another important result of the Phase 1 study was the overwhelming impact of accessibility on the socio-economic level of the settlements. Limited accessibility is synonymous with preserved forests. Living in an isolated location presents the advantage of being closer to the natural resources: wild boar, fish, gaharu, ladang, etc. But it also means high transportation costs, high prices for manufactured goods, low prices for agricultural and forest products, and, overall, limited access to education and to health care. Good accessibility, on the contrary, allows better access to services and markets.

In order to assess the diversity of situations faced by the Punan and their social and economic profile we undertook a number of detailed studies.

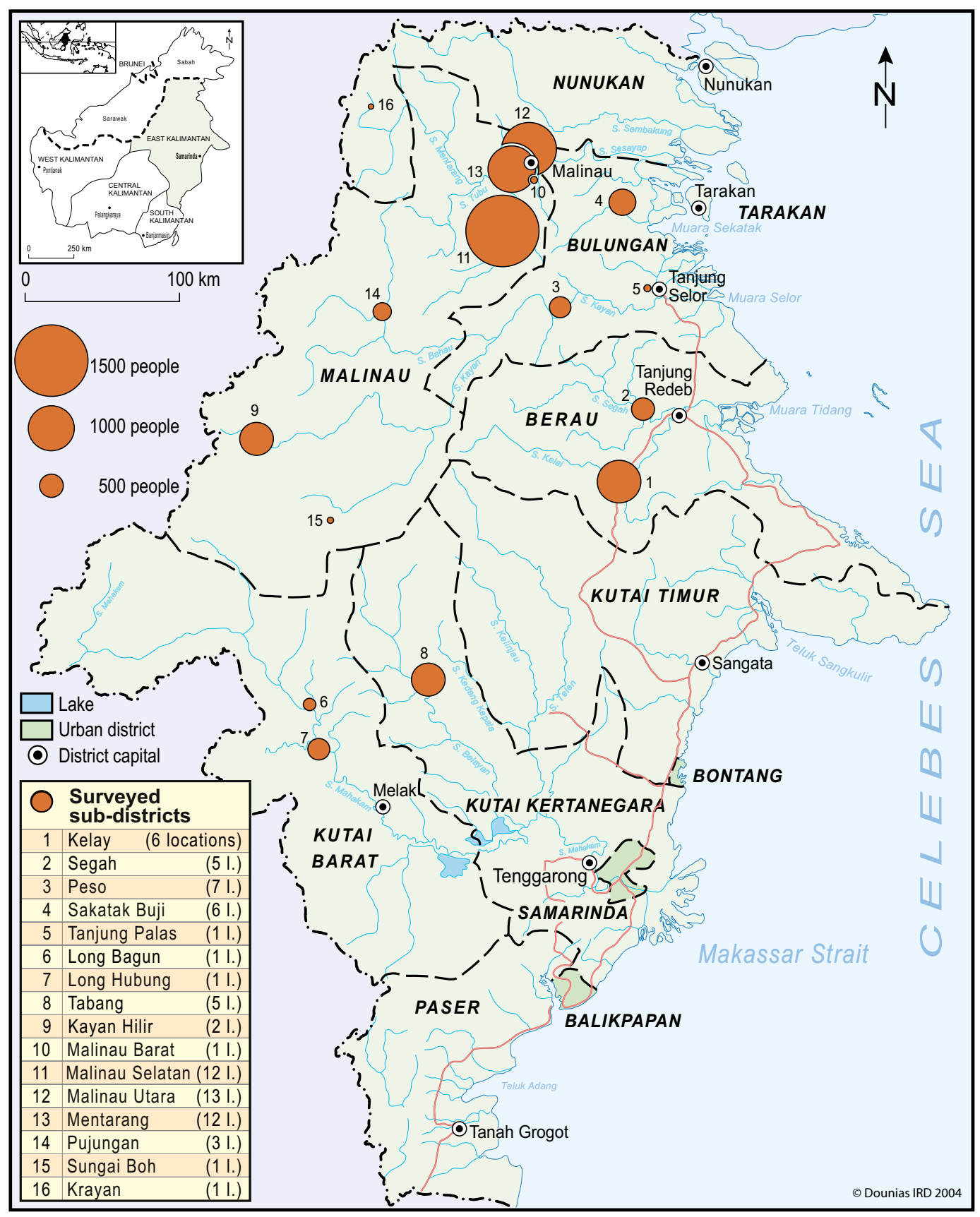

Figure 1. Localities of Punan settlements in East Kalimantan 


\section{APPROACH}

A three-phase approach was adopted. The first was a broad-scale census of all Punan households in the region. The second was a detailed household survey of livelihood activities. Lastly, a small poll was conducted to ascertain Punan opinions regarding the advantages and disadvantages of living in or out of the forest.

\section{Broad-scale census}

A census of all Punan settlements in East Kalimantan (Figure 1) was conducted with the help of the Yayasan Adat Punan (Association of Punan Communities) during 2002 and 2003. The census covered 77 settlements consisting of 2,096 households and 8,956 people (Sitorus et al., 2004). Surprisingly to us, this represented only $0.35 \%$ of the total population of the province. At the settlement level we recorded the distance to the nearest basic services and facilities such as shops, schools, clinics, etc. At the household level we recorded data about all family members, including age, relationship to the household head, gender, education level, and deaths of children and infants. Young married couples still living with their parents or in-laws were considered as independent households. Additionally, household assets such as chainsaws, televisions, boat engines, etc., were enumerated, along with notes on the condition of buildings.

Considering the range of livelihoods, accessibility appeared to be the main cause of heterogeneity among the 77 settlements surveyed. In order to facilitate comparisons we ranked all settlements into three classes:

- very remote: settlements located more than three days' travel from a district capital by boat and on foot

- accessible: villages located less than half a day's travel from a district capital by boat, road and on foot

- remote: all others

\section{Household survey and monitoring}

In order to obtain a detailed and precise picture of livelihood fluctuations over distance, we initiated a household survey in seven different locations chosen according to their accessibility, distance to forest resources and distance to the market. A total of 254 households were included. Along with the demographic and asset profile from the census, we also recorded details of livelihood activities, staple food sources and incomes. The households interviewed in 2002 were again interviewed in 2004 to assess changes in livelihood activities and incomes.

\section{Opinion poll}

An opinion poll was taken in two locations (Respen Sembuak and the Upper Tubu) to assess perceptions among the Punan. In each location, a panel of the young, middle-aged and old males and females was asked to identify and to rank what they considered as advantages and disadvantages of living in their present location. Then 116 villagers in Respen and 81 in the Upper Tubu were individually asked to pick the three advantages and disadvantages they considered the most important.

\section{RESULTS}

\section{Broad-scale census}

Very remote settlements are home to $9.6 \%$ of Punan (Table 1). These settlements have no direct access to retailers, markets, a dispensary or school. Accessible settlements benefit from all four services and host $9.3 \%$ of the Punan. The vast majority $(81.1 \%)$ of Punan live in intermediary settlements where at least one out of the four services is available. More detail is provided by Levang et al., (2005). Though access to formal education is quickly improving $(85 \%$ of the settlements now have a school), illiteracy rates remain high, especially among elderly people and women. There is a strong correlation between accessibility and literacy rates (Table 1 ).

Access to health care is very problematic as only $43 \%$ of all Punan settlements are located close to a dispensary or hospital. Sanitary conditions are poor and hygiene is dubious, especially among children. Child mortality was calculated by taking the percentage of the number of children who died of the total number of children born. The rates are high by any standard, but alarmingly so for the most remote settlements (Table 1), where, on average, child mortality is five times higher in 
Table 1. Differences in selected household characteristics in relation to accessibility of the settlement (\%)

\begin{tabular}{|c|c|c|c|c|c|}
\hline \multirow{2}{*}{ Attribute } & \multirow{2}{*}{ Category } & \multicolumn{3}{|c|}{ Relative distance from District capital } & \multirow{2}{*}{$\begin{array}{c}\text { All } \\
\text { settlements }\end{array}$} \\
\hline & & Very remote & Remote & Accessible & \\
\hline \multirow[t]{5}{*}{ Demographics } & No. of inhabitants & 9.6 & 81.1 & 9.3 & 100.0 \\
\hline & Males under 15 & 40.7 & 35.9 & 35.5 & \\
\hline & Females under 15 & 42.0 & 37.4 & 30.3 & \\
\hline & Males over 65 & 0.0 & 2.3 & 0.2 & \\
\hline & Females over 65 & 0.5 & 1.9 & 0.0 & \\
\hline \multirow[t]{3}{*}{ Illiteracy rates } & Illiteracy male & 54.9 & 33.5 & 16.8 & 33.6 \\
\hline & Illiteracy female & 76.7 & 48.9 & 29.9 & 49.3 \\
\hline & Illiteracy all & 65.8 & 40.9 & 23.3 & 41.2 \\
\hline Child mortality & Average child mortality & 36.0 & 27.0 & 7.0 & \\
\hline \multirow[t]{7}{*}{ Assets owned } & Long tail engine & 27.9 & 47.5 & 25.7 & 43.8 \\
\hline & Outboard engine & 1.0 & 5.4 & 1.2 & 4.6 \\
\hline & Chainsaw & 5.9 & 16.3 & 9.4 & 14.7 \\
\hline & Generator & 0.0 & 7.5 & 0.0 & 6.2 \\
\hline & Television & 0.5 & 11.3 & 22.8 & 11.2 \\
\hline & VCD & 3.4 & 10.5 & 4.1 & 9.3 \\
\hline & Refrigerator & 0.0 & 1.8 & 0.6 & 1.5 \\
\hline
\end{tabular}

very remote settlements than in villages closer to towns. Life expectancy is rather short, with no significant difference according to accessibility, as shown by the very small percentage of people over 65 years of age.

The main scientific question arising from these figures concerns the reason for these differences in child mortality according to the location of the settlement. Is this higher mortality due to unhealthier life conditions in the forest or to limited access to health care? The answer to this question is important for public health officers in order for them to choose the most effective solutions with regard to health-care provision. Faced with this major problem, the IRD (Institut de Recherche pour le Développement) team decided to initiate the 'diet and disease' research programme. In brief, this research concluded that the diet and fitness of Punan living in the forest was on average a little better than those of Punan living in towns (see Dounias, this volume). The main cause of child mortality in remote settlements is due to the exposure to malarial epidemic infections. The disease, brought in by migrants returning from Malaysia, has a disastrous impact on young children lacking immunity in an environment free of most transmissible diseases (Dounias and Froment, 2006). Quite paradoxically, the healthier forest environment is the main reason for higher child mortality. As a consequence, opening up remote areas in order to access health services appears to be one of the best solutions to the problem of high child mortality in isolated settlements. Meanwhile, local public health services need to be upgraded. Visits to remote settlements by travelling medics and the regular distribution of appropriate medicine should both become routine. Cooperation between district health services and Médecins du Monde has recently been initiated for this purpose.

About $80 \%$ of Punan households own their house. One-fifth either lives in huts on their swiddens or share a house with a relative. As usual in Kalimantan, houses are made of wood and built on stilts. According to the Punan, poor housing means a bark floor and walls, and a thatch roof. About $13 \%$ of the households live in such conditions, mostly in the remotest settlements. Only 3\% of the houses are equipped with toilets and $4 \%$ with a complete bathroom. All others rely on the nearby river for their sanitation and washing needs.

With reference to household assets, nearly half of the families own at least one boat engine (long-tail or outboard). Chainsaws are common equipment in remote villages, while televisions 


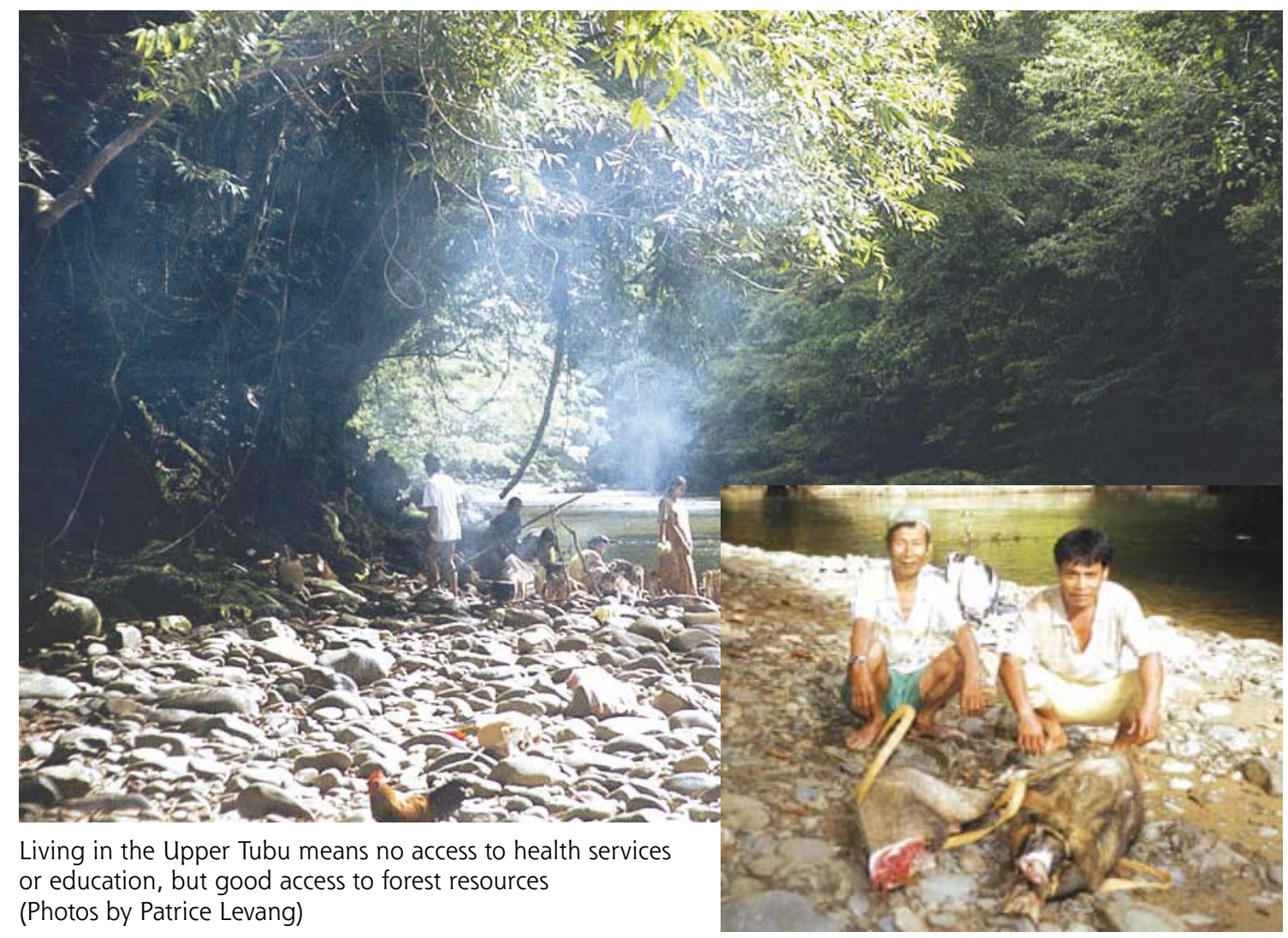

andVCDs are well distributed in settlements close to towns with electricity (Table 1). Considering assets, Punan households largely keep up with other ethnic groups of the district. Phase 1 research already concluded that the same was true for incomes. As Punan households generally give priority to cash-earning activities, such as gaharu collection, over subsistence activities, the average monetary income of Punan settlements is often higher than the average monetary income of neighbouring Dayak villages.

\section{Household survey and monitoring}

Household survey results indicated that there were many differences between settlements and between households within the same settlement. However, overall, three major types of Punan settlements emerge from the census and household surveys. These types are clearly related to their location on the watersheds:

- The diversified settlement type corresponds to the 'accessible' category of the census. These settlements are located close to district capitals, along roads or major waterways.
They benefit from good access to markets and services and households have multiple opportunities to make a living;

- The gaharu collectors' settlement type is located mid-stream, in rather remote but not too isolated areas. Heads of households are trapped in debt with patrons specialised in forest product trade. For the time being, gaharu is the main, if not only, article of trade. Other products such as birds' nests, bezoar stones and game are secondary in importance when compared to gaharu. Though gaharu collection is their main activity, nearly all households farm small swiddens to ensure at least partial food security;

- The subsistence type concerns families living in very remote settlements where accessibility is so limited that traders seldom visit the area. Households depend on agriculture and on forest products for their daily needs. Opportunities for cash earnings are rare.

Considering Punan livelihoods in more detail, three strategies dominate: namely agricultural activities, forest product collection and off- 
Table 2. Participation and contribution to cash incomes from primary livelihood sources of households in settlements of different distances to district centres

\begin{tabular}{|c|c|c|c|c|c|c|c|}
\hline \multirow{2}{*}{$\begin{array}{l}\text { Livelihood } \\
\text { source }\end{array}$} & \multirow[b]{2}{*}{ Category } & \multicolumn{2}{|c|}{ Very remote } & \multicolumn{2}{|c|}{ Remote } & \multicolumn{2}{|c|}{ Accessible } \\
\hline & & $\begin{array}{c}\% \\
\text { partic }\end{array}$ & $\begin{array}{l}\% \text { of } \mathrm{hh} \\
\text { income }\end{array}$ & $\begin{array}{c}\% \\
\text { partic }\end{array}$ & $\begin{array}{l}\% \text { of } \mathrm{hh} \\
\text { income }\end{array}$ & $\begin{array}{c}\% \\
\text { partic }\end{array}$ & $\begin{array}{l}\% \text { of } \mathrm{hh} \\
\text { income }\end{array}$ \\
\hline \multirow[t]{3}{*}{ Agriculture } & Rice cultivation & 88.6 & 34.8 & 93.9 & 19.9 & 91.7 & 15.0 \\
\hline & Animal husbandry & 82.9 & 2.5 & 22.2 & 2.0 & 16.7 & 1.4 \\
\hline & Total: all agriculture & 100.0 & 37.8 & 93.9 & 25.3 & 92.5 & 18.9 \\
\hline \multirow{6}{*}{$\begin{array}{l}\text { Forest } \\
\text { products }\end{array}$} & Fish & & & 13.1 & 0.4 & 19.2 & 1.4 \\
\hline & Gaharu & 85.7 & 30.3 & 70.7 & 34.3 & 22.5 & 4.5 \\
\hline & Birds' nests & 5.7 & 0.6 & 5.1 & 2.5 & 4.2 & 3.8 \\
\hline & Timber & & & 8.1 & 3.9 & 22.5 & 9.6 \\
\hline & Bushmeat & 17.1 & 1.0 & 6.1 & 0.5 & 12.5 & 2.1 \\
\hline & Total: all forest prod & 94.3 & 36.5 & 79.8 & 42.7 & 60.0 & 21.8 \\
\hline \multirow{5}{*}{$\begin{array}{l}\text { Off-farm } \\
\text { activities }\end{array}$} & Honorarium & 28.6 & 16.2 & 13.1 & 5.4 & 26.7 & 6.1 \\
\hline & Fees & & & 54.4 & 9.5 & 70.8 & 28.6 \\
\hline & Salaried worker & & & 1.0 & 0.7 & 4.2 & 4.1 \\
\hline & Civil servant & & & 1.0 & 2.1 & 4.2 & 5.4 \\
\hline & Total: all off farm & 51.4 & 25.7 & 82.8 & 32.0 & 97.5 & 59.3 \\
\hline
\end{tabular}

farm activities (Table 2). Broadly speaking, the contribution of these three strategies is relatively equal in the very remote sites. This changes in favour of forest products in the remote sites as they as are more conveniently located with relatively easy access to both forest resources and markets. And finally, in more accessible communities, off-farm activities predominate.

Agricultural activities entail essentially the swidden cultivation of upland rice. The majority $(92 \%)$ of all households surveyed produce rice, mostly on swiddens, and in rare cases in lowland conditions. Rice is set aside for the family's consumption or sometimes bartered for other goods, but rarely sold. There is large variation in the size of the area planted and in subsequent yields. Though the total rice production in 2002 covered the needs of the population, only $51 \%$ of the households proved self-sufficient. When rice stocks are finished, the family resorts to the consumption of cassava, corn or taro, which is frequently intercropped with the rice. When all crops have been consumed, wild sago starch serves as the ultimate safety net. Sago is absent from the diet of villages close to markets, but can represent $12 \%$ in very remote settlements, such as those of the Upper Tubu. The contribution of secondary food crops, plantation crops and animal husbandry to the family's cash income is almost always minor (Levang et al., 2005a).
Forest products collection involves a large number of households, especially in areas with intermediate accessibility. Gaharu collection is the main cash-providing activity for most households. Birds' nest collection generates higher incomes but involves only a limited number of families. The same is true for timber extraction, especially in the more accessible settlements. Other products such as fish, bush meat and honey are still relatively unimportant apart from in villages close to urban markets.

Income generated from off-farm activities is generally high but involves only a limited number of families located in accessible settlements. Salaried workers and civil servants are rare among the Punan. Honoraria for duties in village administration appears important because of the small size of most Punan villages; on average five persons receive honoraria in villages of approximately 20 families. Day labourers can find occasional jobs in urban areas. Income from retailing or trade is minor as most traders are outsiders. Gold panning and handicrafts provide additional income in specific areas. The only source of income available to all families in a settlement is the redistribution of fees or royalties to the local population by loggers and coal miners. Therefore, most villagers are eager to strike deals with them (Sitorus, 2004; Levang et al., 2005b). 
The relative contribution of the different sources to the households' total income is closely linked to the accessibility of the settlement (Figure 2). The contribution of agriculture is relatively similar in all settlements because it is dominated by swidden rice farming, an activity practised by nearly all households. Forest product collection dominates in intermediate locations, while the largest range of off-farm activities can be found in villages close to town. On average the annual income of a Punan household in the region in 2002 ranged from 11 million rupiah in accessible villages, to 8 million rupiah in intermediate locations and slightly more than 4 million rupiah in very remote areas.

The overall dependency of Punan households on forest resources, directly and indirectly, is still strong. On average nearly one-third of the total income is provided by the collection of forest products, mainly gaharu and timber. If one adds the fees paid by loggers to communities, then together they would represent half of the total household income. Considering that agricultural activities strictly depend on the availability of primary and secondary forests for swidden cultivation, and that most wage labour and other off-farm labour opportunities are provided by loggers, then it is likely that more than $75 \%$ of the total income is derived from forest resources.
This result is hardly surprising since the Punan have always been dependent on forest resources. However, faced with modernity there has been a tremendous shift from sustainable dependency to unsustainable dependency. The rush for gaharu has been such that the current high collection costs discourage most gatherers and even traders from organising long collection trips. In relation to hunting for bezoar stones, the shift from blowpipes to shotguns has meant leaf monkeys (Presbytis spp.) are on the verge of extinction. In all accessible areas, the forest has been first overexploited by large concessionaires and then plundered by illegal loggers. With few exceptions, communities are ready to agree deals with loggers for the right to log the forests under their control (Sitorus, 2004; Levang et al., 2005b). Most deals involve the conversion of forests into plantations. However, rather than developing plantations at high cost, the loggers take all merchantable stems and compensate the communities directly with cash. Deal after deal, the timber-rich forests surrounding the villages are converted into scrubby bush and no plantations are ever developed (Andersen \& Kamelarczyk, 2004; Sitorus, 2004; Levang et al., 2005b). Making easy money is a favourite discussion topic. With an average income of more than 9 million rupiah per household per year, the Punan cannot be regarded as poor according to Indonesian standards. However, the range

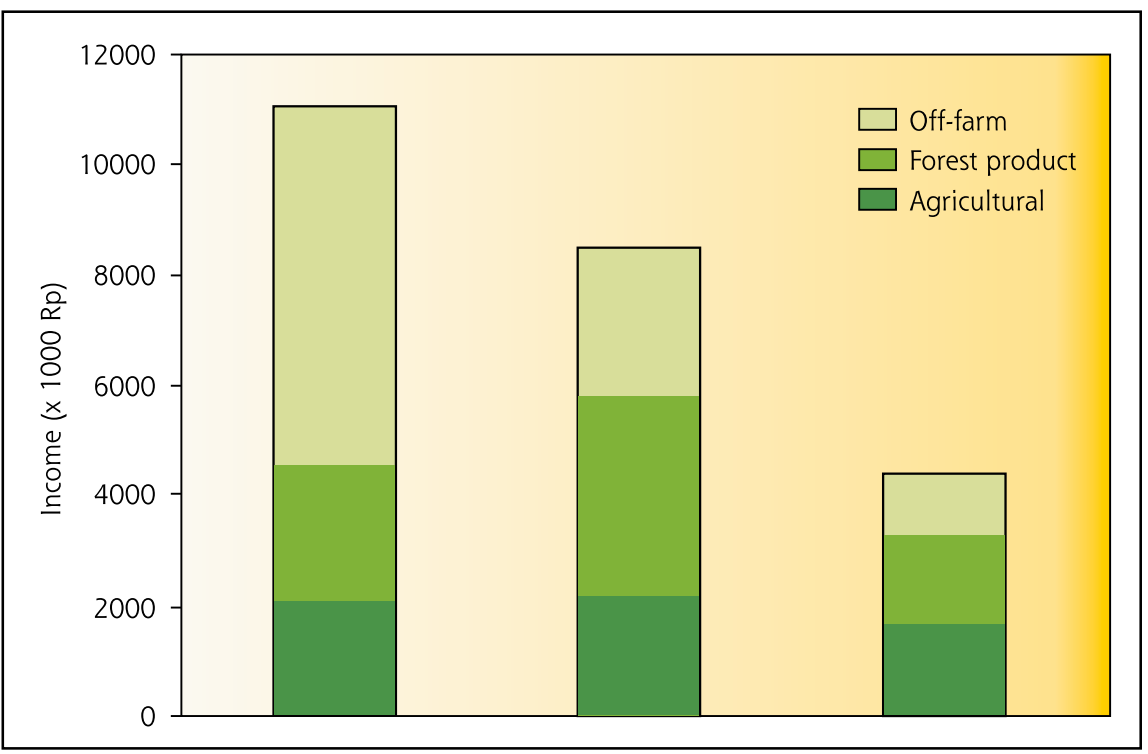

Figure 2. Average annual household income by source (2002) 
between the poorest (Rp 180,000 per year) and the richest household ( $R p 121$ million per year) is significant (Figure 3).

This large heterogeneity in livelihood strategies is linked either to the settlement's location or to household's livelihood portfolio. About $83 \%$ of households are under the poverty line (i.e. earning under US $\$ 1$ a day per capita). According to Indonesian standards of poverty for East Kalimantan defined by Pradhan et al. (2001), about $39 \%$ of households in our sample are under the poverty line. This ratio is quite similar to the $35 \%$ of poor obtained by these authors for EastKalimantan rural areas in 1999. The highest occurrence of poor families is found in the remotest areas. In the Upper Tubu for instance, $66 \%$ of families are under the poverty line. In intermediate locations, wherever settlements benefit from fees paid by loggers, all households move above the poverty line. In locations with good accessibility only very few families can be labelled as poor. Job opportunities are generally more numerous than people willing to grasp them. The huge difference in income between settlements is mainly due to differential access to markets and services.

\section{The monitoring of Punan households}

The main feature of Punan household income is its unpredictability. In swidden cultivation, upland rice yields are sensitive to drought, especially those happening shortly after the flowering stage. Gaharu collection is a major gamble. A three-week collection tour can end in a jackpot or in bankruptcy. On average, though, the collector breaks even. Off-farm income opportunities considered as worthwhile by Punan households are rare. Even at Rp 50,000 per day few Punan or Dayak will agree to carry out earthworks. Since Malinau became a District, countless job opportunities can be fulfilled only by migrant workers.

Apart from a dozen or so people employed by the civil service, Punan families generally lack regular and secure income. To assess interannual variations, we decided to monitor the economic performance of the households of the 2002 survey in two different locations, the Upper Tubu and Respen Sembuak (a settlement close to Malinau city). In 2004 we revisited the households surveyed in 2002 in the Upper Tubu and Respen. Additional locations were added to complete our sample.

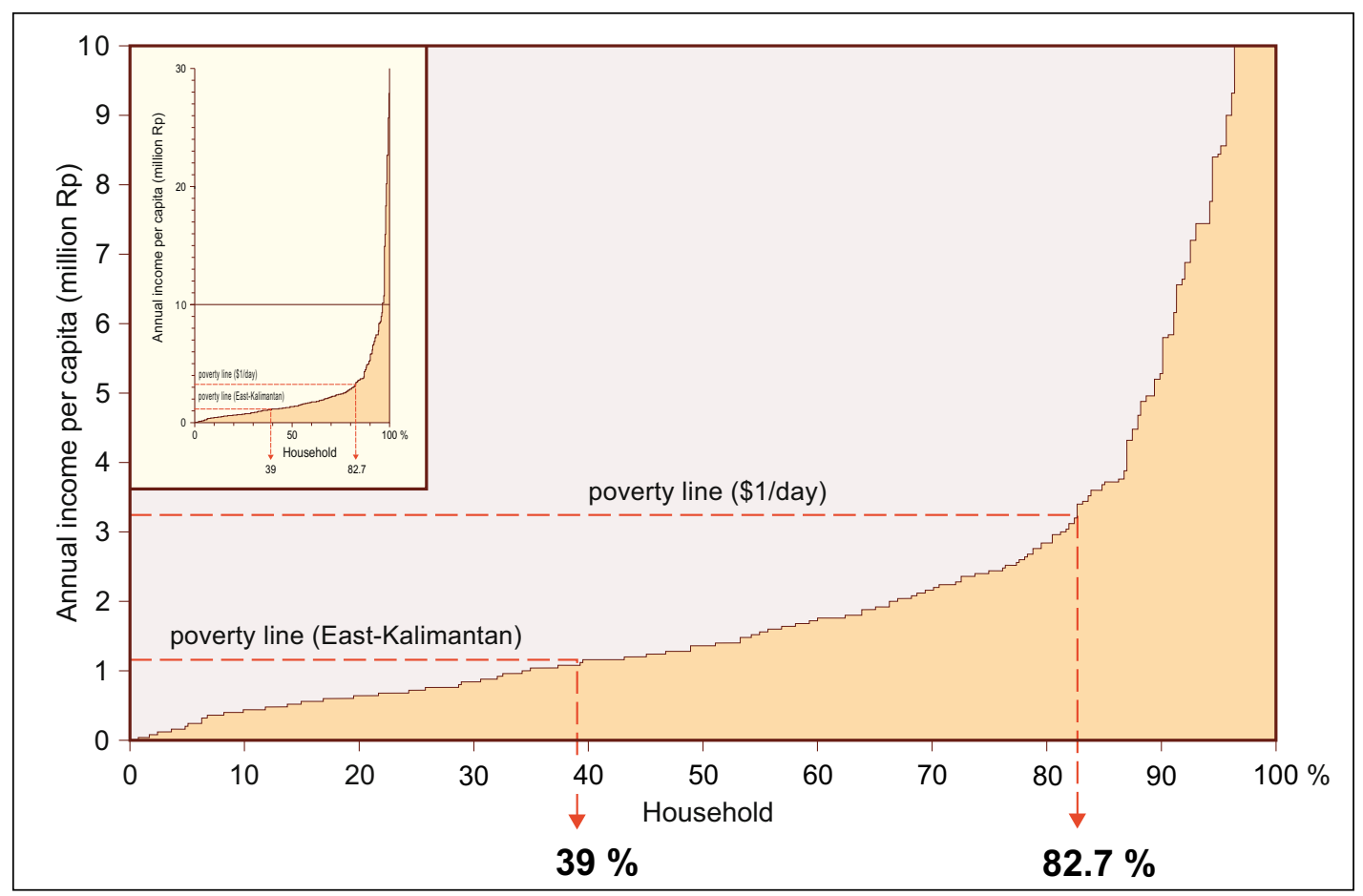

Figure 3. Distribution of annual income per capita (2002) 
The comparison between the two years is rich in information and illustrates the unpredictability of the Punan households' income (Figure 4). The average annual income of Respen Sembuak dropped from 14 to 12 million rupiah between 2002 and 2004. If one excludes incidental incomes, such as land sales or compensation for expropriation, the average annual income declined from 12 to 7 million rupiah in Respen Sembuak during the two years. In contrast, in the very remote location of the Upper Tubu, the average annual income per household remained stable, albeit significantly lower, at around 4 million rupiah.

In both locations the 2004 rice yields dropped (by as much as half) because of an unusual long dry spell during the flowering stage of the upland rice. In the Upper Tubu and in the Pujungan area the rice harvest provided self-sufficiency for only three months on average. In order to buy rice on the market or from traders, most families increased the number of gaharu collecting tours. In the absence of credit from traders, collectors had to make do with short trips in the vicinity of the villages. As a consequence, gains were low. To compensate for the lack of rice, most families resorted to consuming wild sago.

In Respen Sembuak the families resorted to buying rice. At the same time as the drought and poor rice harvest, the price of fuel increased markedly. In consequence, rather than risking scarce cash resources on transport for perhaps risky long-distance gaharu collecting tours, the more entrepreneurial families opted for logging along riverbanks or main roads. This shift in activity was in line with the shift in interest of many gaharu traders. As good-quality gaharu disappears or at least becomes more difficult to find, collecting costs increase and so do the financial risks for traders. More and more collectors return empty handed and are thus unable to repay their credit. Consequently, some traders are forced to give up the gaharu trade and commence 'informal' logging instead. Apart from the major decline in income from agriculture and gaharu collection, some families in Respen Sembuak lost their salaried jobs with concessionaires and many more were no longer in a position to find jobs as day labourers, because of competition with other ethnic groups.

At the household level within each settlement, income unpredictability is also widespread. Because of the fickle nature of gaharu collection, income may vary greatly from year to year. In the Upper Tubu, the household's income is closely linked to gaharu finds and to offfarm employment opportunities. Both sources of income are highly variable over time. The better-off families are not the same in 2002 and in 2004. Only the poorest families, those whose members are unable to collect gaharu, because they are old, the disabled and women, are certain to remain poor. The same applies

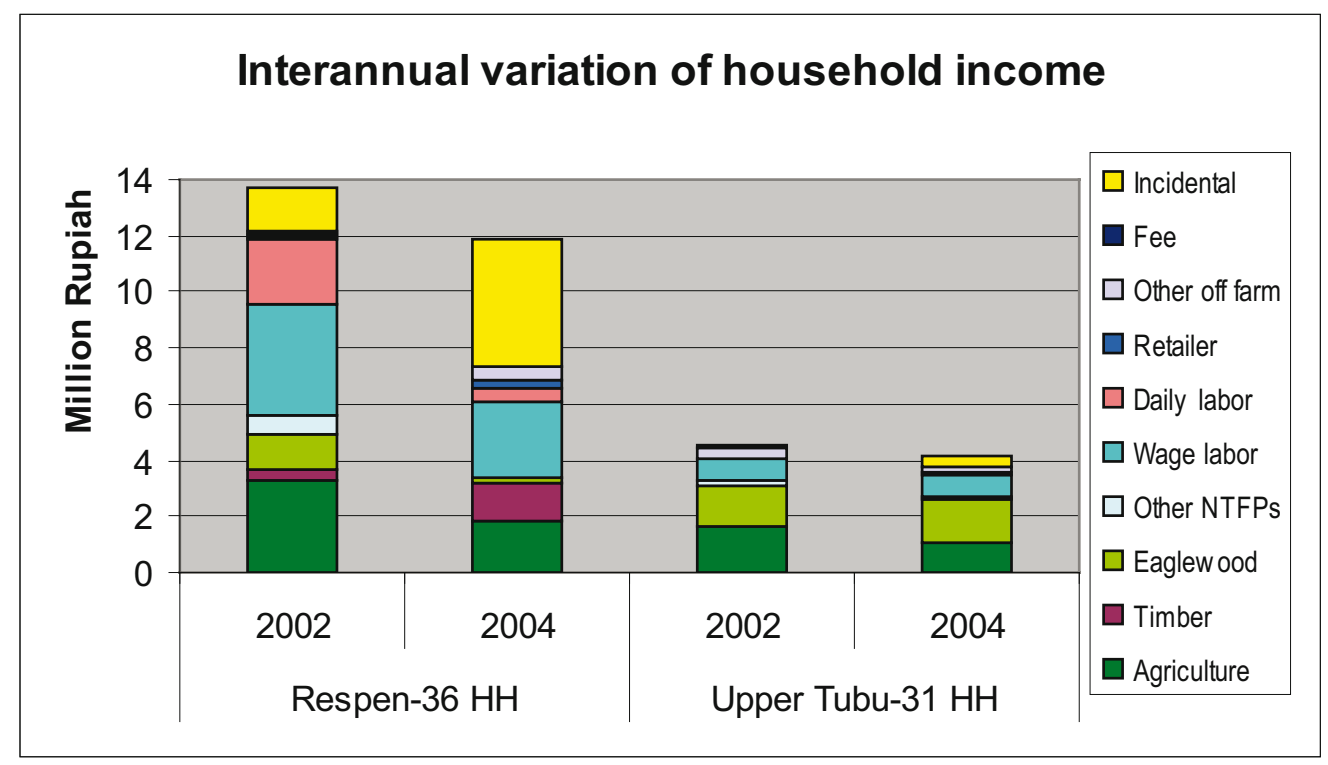

Figure 4. Inter-annual variations at settlement level (2002 and 2004) 


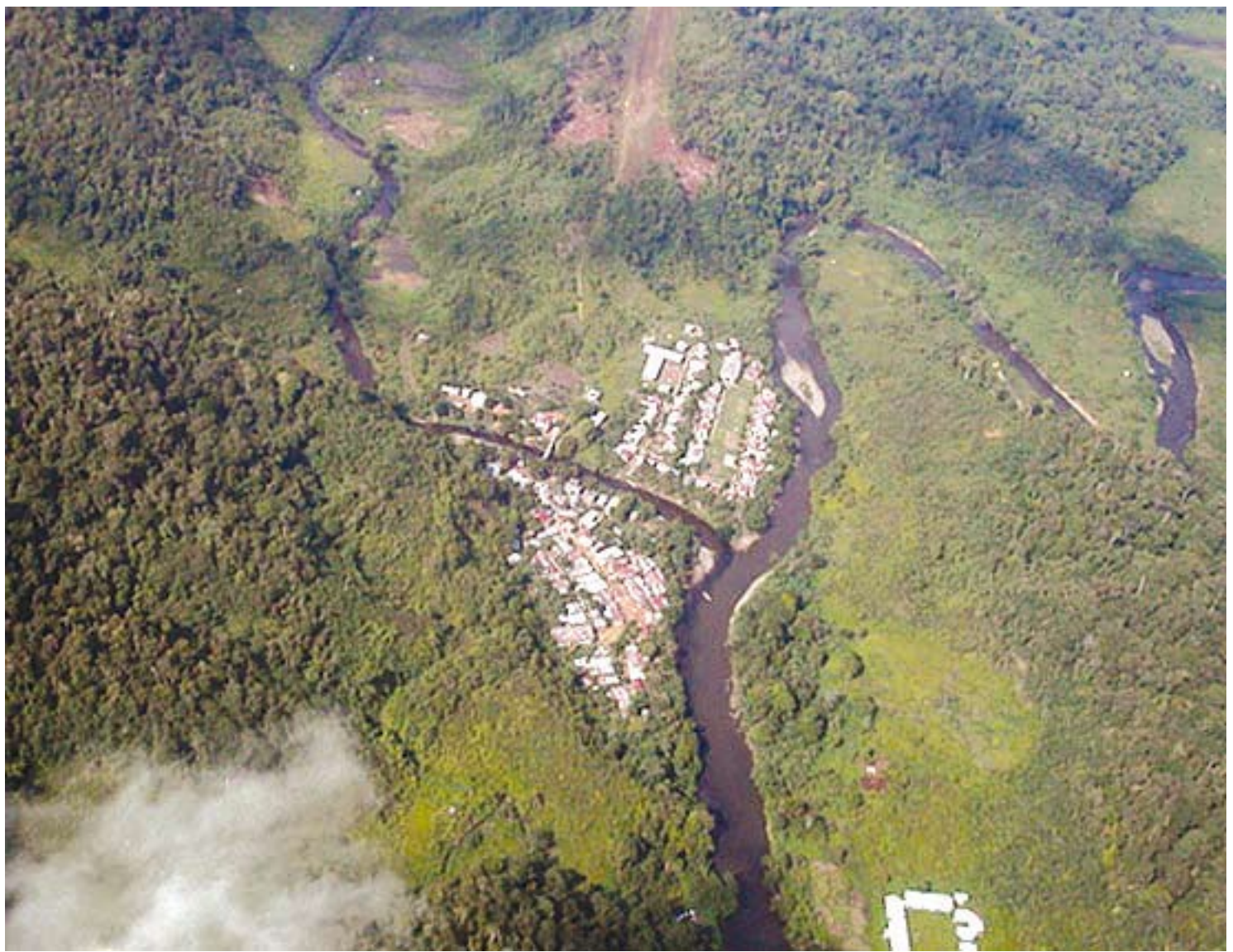

Sule-Pipa in the remote Apo Kayan is similar to a small town in the middle of the forest

(Photo by Patrice Levang)

more-or-less to Respen Sembuak. Better-off families in 2002 generally had less income in 2004 because of the considerable decline in off-farm employment opportunities. Somewhat surprisingly, the poorest families in 2002 are doing rather better in 2004. The reason for this is that only the poorest households accept day labourers' jobs available in town.

The economic situation deteriorated to a greater extent in Respen Sembuak than in the Upper Tubu. In 2002,39\% of the households of Respen earned more than 10 million rupiah per year. This figure dropped to $25 \%$ in 2004 . In the Upper Tubu the percentage of households earning over 10 million rupiah dropped from $16 \%$ to $13 \%$ for the same years. Though more stable in the Upper Tubu, the economic situation of households in Respen Sembuak is still better. But opportunities and constraints constantly change. Gaharu collection has become too costly and risky. What is going to replace gaharu? Timber was an interesting opportunity for a time. But today, easily exploitable timber along waterways and main roads is no longer available. Well-paid salaried jobs with concessionaires are rare and seldom open to Punan. The same applies to civil servant jobs. Currently the Punan are not ready to accept jobs as day labourers. Consequently, for most, the only choice they have is to sell their forest to loggers or to return to the forest. Both have advantages and drawbacks.

\section{Punan opinions on the pros and cons of living in and out of the forest}

The Punan of Respen Sembuak benefit from all positive effects of development in terms of both access to services and goods (Table 4). Life without electricity, rice mills, transportation, television, video players and more recently mobile phones is difficult to imagine for the younger generation. Integration is occurring. 
Table 4. Opinion poll: pros and cons of living in and out of the forest (\% of respondents)

\begin{tabular}{|c|c|c|c|c|}
\hline \multirow{2}{*}{ Positives } & \multicolumn{2}{|c|}{ Living in the forest (Upper Tubu) } & \multicolumn{2}{|c|}{ Living out of the forest (Respen Sembuak) } \\
\hline & Forest products for food & 77 & Access to dispensary & 76 \\
\hline & Land for swidden & 65 & Access to education & 58 \\
\hline & Forest products for cash & 55 & Access to information & 37 \\
\hline & & & Work opportunities & 33 \\
\hline \multirow[t]{3}{*}{ Negatives } & No health care & 67 & Lack of security & 62 \\
\hline & Basic goods expensive & 59 & Drugs and alcohol & 54 \\
\hline & Poor accessibility & 41 & Loss of Punan culture & 46 \\
\hline
\end{tabular}

On the negative side, the Punan complain that in town nothing is for free. Money is needed for everything as even bush meat is no longer distributed among neighbours but sold on the market. The older generation particularly resents the loss of Punan culture. Benefiting from a better education is no guarantee for a better job. The Punan generally lack the connections essential to be recruited as civil servants or company employees. This situation creates many frustrations among young Punan graduates. Consequently, many parents become reluctant to send their children to university due to the high cost and seemingly little improved employment prospects afterwards. Young people become prone to alcoholism and drug addiction because of frustration and unemployment. Mingling with other ethnic groups does not always foster integration, and even urban Punan feel marginalised and are made fun of by their neighbours. With the rapid development of the city of Malinau, the building of the bridge over the Sesayap River and the opening of new good-quality roads, Respen Sembuak has become a close suburb. The price of landed property soared to previously unknown levels. As a consequence, the Punan are either offered high prices for their land or scared off in order to make them leave. Quite often, individuals from the Tidung ethnic group, the traditional owners of the resettlement area, make aggressive claims to regain the land which was given to the Punan by the government at a time when the land had no commercial value.

Some families consider going back to their ancestral land of the Tubu as a viable option. There, wild boar is plentiful, rivers have an abundance of fish, gaharu is closer, and land for swiddens is available in large quantities. Furthermore, the forest is still rich in valuable timber which might attract loggers and thus provide fees for the community. When asked about the numerous drawbacks - isolation, high price of goods, distance to market, lack of services, etc. - the families argue that it is the duty of the government to make services available as far as the remotest settlements. It is clear that the Punan want to benefit from the advantages of both locations. They are little prepared to give up the positive aspects of modernity, and thus ideally, want to enjoy city life in the middle of the forest (Levang et al., 2007). The same kind of contradiction rules their identity problems. They want to uphold their identity and to carry out the traditional life of hunter-gatherers, but at the same time they reject marginalisation and seek integration into the larger society. Overall, they hanker for integration without loss of identity, mirroring similar dynamics with forest dwellers elsewhere in the world (Bahuchet et al., 2000).

\section{WHAT FUTURE FOR THE PUNAN: IN OR OUT OF THE FOREST?}

When in the early 1970s the government insisted that the villages of the Tubu were resettled closer to the town of Malinau, the main aims were to reinforce its control over isolated populations and to move the people closer to services. Thirty years later this policy clearly has had some benefits, especially in economic, educational and health terms. The comparison with villages which refused to move and stayed in the Upper Tubu is stark. Infant and child mortality is five times lower in resettlement villages, illiteracy has been erased among the younger generation (both male and female) and, on average, household incomes are two to three times higher. 
Livelihood portfolios also differ. Communities within the forest, well divorced from markets and amenities, have a mix of livelihood strategies, based on using the land and resources available to them. This includes rice cultivation, collection of forest products and animal husbandry. Cash incomes are low, but relatively stable from year to year. The forest and forest land provides most of their needs. In comparison, Punan households close to Malinau have greater cash needs which are met through increased offfarm activities. The activities constitute $60 \%$ of their income. There is opportunistic extraction and sale of forest products, particularly in the face of unpredictable events and shocks, such as drought, or changes in local prices of goods. However, the opinion poll results show that the Punan in both situations face a dilemma. The forest environment provides a degree of selfsufficiency, respect and maintenance of cultural norms, but without modern conveniences, support services and livelihood opportunities in the longer-term. On the other hand, living closer to the urban centres affords a different suite of opportunities for which the Punan are poorly prepared or equipped to grasp. Thus, they hanker after the advantages offered by a forest dwelling, and at times extract forest resources to provide the ready cash needed for their increasingly modern lifestyle. In both situations the Punan are faced with a choice, to stay where they are, or move.

\section{Opting for modernity}

Whatever choice is made, the short-term future looks challenging for the Punan. Many of those who decide to stay in Respen will sooner or later sell their landed property to the numerous outsiders, generally civil servants and salaried employees, recently established in Malinau. The recent opening of the district hospital in Respen has considerably boosted already high prices. Present employment opportunities are not suited to the Punan's abilities and wishes. Only very few individuals have the capacity, education and the work discipline to apply for salaried jobs. And when they have, they lack the connections to be recruited (ethnic and family connections are essential to get jobs in the public as well as in the private sector). The only jobs available to them are day-labourer positions, but these jobs are generally considered unsuitable by most Punan, less because of their remuneration than because of their strenuousness. Gaharu collection is no longer a viable option for urban Punan due to the increasing scarcity of the resource and consequent high transportation. Even 'informal' logging is no longer attractive as the easiest accessible sites have already been exploited. Obtaining fees from loggers for the conversion of their forests has become the best way to make easy money. Alternative options, such as agricultural intensification, forestry and agricultural plantations, or fish farming could be considered. However, there is little evidence that the Punan will be able to compete with other ethnic groups. Additionally, there is little opportunity or incentive for individuals to stand out, as in Punan culture, successful individual initiatives are rarely considered as examples to follow. Quite to the contrary, they foster jealousy among neighbours and extended family, and often lead to acts of sabotage. As one of our informants put it: 'If all cannot benefit, no one should.' Fortunately, attitudes are changing.

\section{Back to the Tubu}

The issue of returning to the Tubu is nothing new for the Punan. It has been the major topic of conversation in Respen for several years, but up to now has been talk rather than action. There is a wide range of reasons for returning to the Tubu. Getting closer to abundant and freely available forest products and gaining security of tenure are as often cited as fleeing urban insecurity. Less cited, but present in all minds, is the fear that if the Tubu is no longer inhabited, the Punan will loose their ancestral land rights. Recently this fear has been strengthened by the official merging of all former villages of the Tubu, regrouped in Respen Sembuak, into one single village. By losing their former village status, their claims over former village areas have been considerably weakened. The recognition of these claims is not only a matter of tenure security and cultural identity; the Tubu watershed is still largely forested and rich in high-quality timber. Other resources, such as gold and coal have also been identified in the area.

There is considerable consensus among all Punan, old and young, male and female, that they should return to the Tubu. However, nobody agrees on the terms and practical details of such 
a return. Few would consider doing it without the urban facilities they have been enjoying for years. Thus the Punan want the 'government' to help them build modern villages along the Tubu, provide dispensaries and schools, market facilities and good road access. The government, however, is reluctant to entertain such ideas. The recent attempt by the sub-district of Mentarang to regroup the Punan of Rian Tubu in a single location at the confluence of the Rian and the Tubu rivers illustrates the problems inherent in such a venture. Once the location had been chosen and the first investments made, dissent within the community regarding leadership pushed a majority of households to refuse to move to the newly developed location. It was not the first time that facilities built at high cost by the sub-district were abandoned after only two or three years.

Considering the limited development budget of the district, building a road, schools and dispensaries does not make sense if the villages are to be moved every few years. And this risk exists, especially in the Upper Tubu where mobility is still quite high. However, building a road is the only way to open up the Tubu watershed. Given the uneven topography of the area, roads will not only be expensive to build but also to maintain. Numerous attempts made in other locations in Kalimantan prove that without good maintenance provided by larger concessionaires (logging companies or coal miners equipped with graders and bulldozers) roads become impassable after heavy rains. And wherever roads have permanently opened up remote areas, deforestation has been the rule.

Building a road to the Tubu will enable local communities to make a living on fees from loggers until the last tree has been removed from the Tubu. Conversion into plantations is not likely to happen at least in a first stage. The topography is too uneven for oil palm development, and road maintenance would be too costly in the absence of logging.

\section{Finding a middle ground: the Sule- Pipa approach of village regrouping}

In the middle of the Apo Kayan, the villages of Sule and Pipa appear as pleasant exceptions to this gloomy picture. The two villages regrouped on both sides of the Sule confluence with the Kayan Ilir host to 152 households and 712 inhabitants. Though far more remote than the Upper Tubu, Sule-Pipa appears less isolated. Since 1978, the villages have benefited from an airstrip with regular flights to Tarakan, Samarinda or Malinau. Daily radio contact links the villages to the outside world. In case of emergency, if the local dispensary is unable to take care of the situation, a special plane can be called in to evacuate the sick to a hospital. The local primary school has been functioning without interruption since its opening. Out of four teachers, three originate from the village. Since 2003 a small secondary school operates in the village.

Market access is difficult and during the rainy season the village can be reached only by plane. On average, shipped-in goods are three times more expensive than in Malinau. On the other hand, competition is active among traders, and collectors benefit from high prices for their forest products. The economic situation is thriving, as can be seen by the comparison with assets possessed by households in Respen and in the Upper Tubu (Table 5).

Annual household income is dominated by forest products and is even slightly higher than in Respen Sembuak (Figure 5). However, it should be noted that the purchasing power in Sule-Pipa is much lower than in Respen. Child and infant mortality are much lower than in the Upper Tubu and only slightly higher than in Respen Sembuak (Figure 6). Additionally, education levels are similar to those of Respen Sembuak (Figure 7). Illiteracy is even lower in Sule-Pipa than in Respen Sembuak. The percentage of secondary school graduates is higher in SulePipa for males, which is noteworthy considering the much higher cost involved in Sule-Pipa (before 2003 there was no secondary school in the village).

The Sule-Pipa case shows clearly that the negative impacts of remoteness can be overcome. However, providing adequate services in an isolated environment like the Apo Kayan has a considerable additional cost. In Sule-Pipa this high cost has been borne by the GKII mission, which provides free air transportation in emergency cases. Chartered flights can be organised at full cost by private 
Table 5. Households' assets (\% of households)

\begin{tabular}{lccccc}
\hline Location & Boat engine & Chainsaw & TV Parabola & VCD Player & Refrigerator \\
\hline Respen Sembuak & 26 & 9 & 23 & 4 & 1 \\
\hline Upper Tubu & 8 & 9 & 0 & 0 & 0 \\
\hline Sule-Pipa & 70 & 21 & 14 & 11 & 2 \\
\hline
\end{tabular}

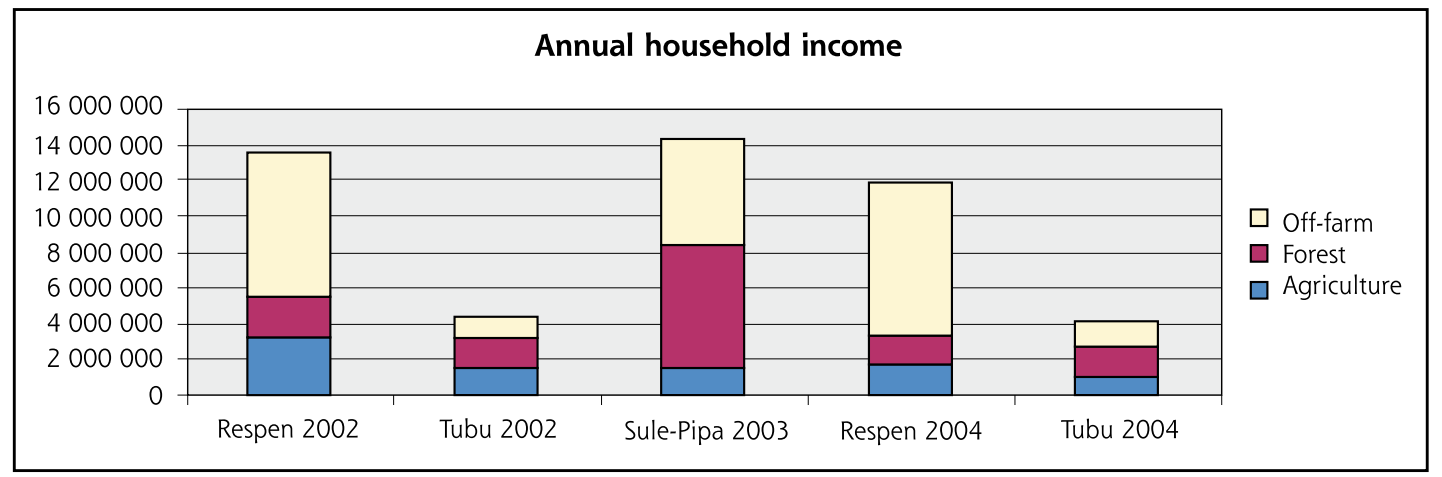

Figure 5. Average annual household income (y axis = Rupiah)

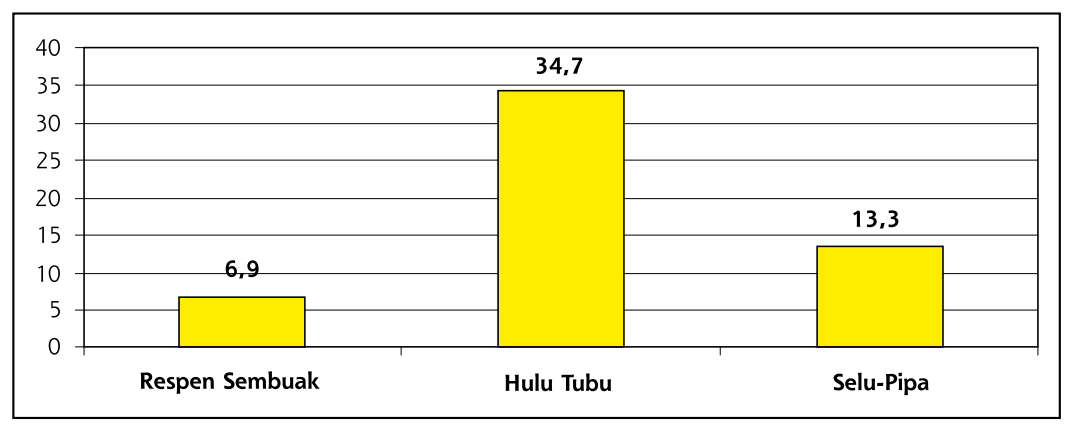

Figure 6. Child and infant mortality (y axis = percent)
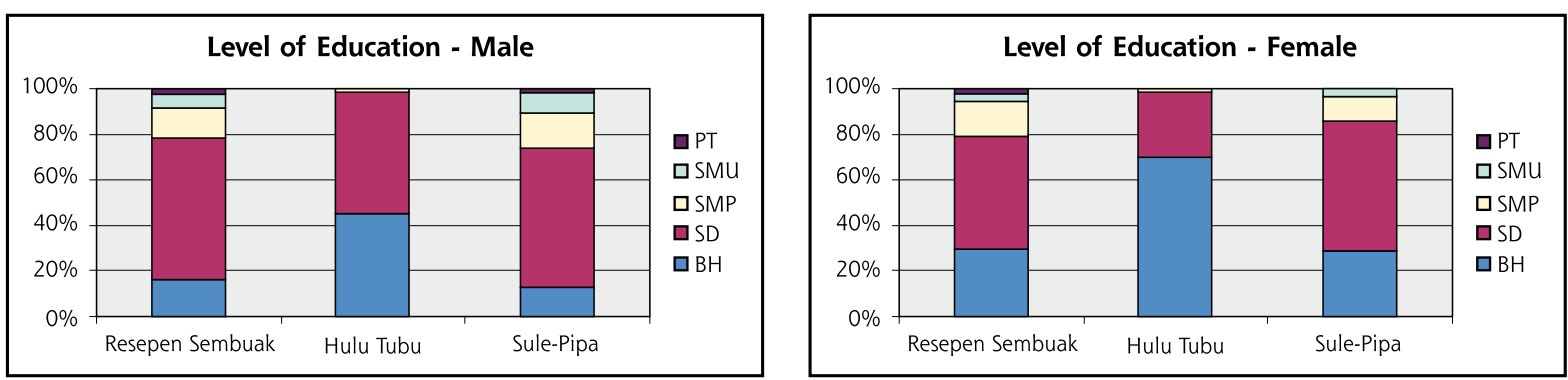

Figure 7. Level of education (Key: BH = illiterate; SD = primary education; SMP = junior high school; SMU = high school; PT = college)

persons, traders, government officials, etc. Since 2002, the district of Malinau subsidises the Malinau-Sule route to facilitate communication with the capital of the district. Eventually environmental payments could be considered as a way to cover the additional cost of providing air transportation to remote settlements. But it should be remembered that covering the costs alone might not be sufficient. Providing reliable services, as is the case in Sule-Pipa, presupposes the backing of a strong organisation and the dedication of its employees. Up to now, only missions have proved able to operate such a route over a long period without interruption. 
Another condition for success is the size of the settlement. A minimum settlement size of 100 to 200 families or more is a prerequisite to make investments in infrastructure profitable and to make the location attractive to civil servants and traders. The regrouping of villages into larger settlements is contrary to Punan culture where small settlements are the norm. Living in small scattered settlements, hunter-gatherers have easier access to forest products and to swiddens, whereas regrouping into villages increases competition over resources. However, regrouping into villages is essential to convince district authorities to fund the necessary infrastructure: airstrip, school, dispensary and administrative facilities. Providing a dispensary to a permanent settlement of 200 families is a sound investment of development funds; doing the same for a temporary settlement of 20 families is not.

\section{Out of the forest, out of poverty, or back to the trees?}

The Punan of the Upper Tubu are caught in a dilemma. By leaving the forest they benefit from all facilities of modernity, but lose access to their forest resources, give up their identity and still prove unable to compete with other ethnic groups. By staying in, or returning to, the forest they have to give up many conveniences and necessities of modern life, including education and health care, which intensifies their marginalisation. There is little doubt that the forest provides important livelihood options for Punan households, but it is not one of first choice. Where options are available, with the trappings of modernity, they invariably opt for them, although they have limited skills and collective experience in this regard. However, knowledge and experience of the forest is useful even for households in accessible settlements, which derive just over one-fifth of their cash income from forest resources. Forest-related income constitutes both a safety net role as well as a regular cash income. However, with improved economic well-being, the importance of income from other sources is likely to grow, and low-income households will then become less dependent on forests (Byron \& Arnold, 1999; Wong \& Godoy, 2003).
The Sule-Pipa success story demonstrates one model to address this dilemma. The Punan Tubu could come together and create a thriving settlement in one or two locations chosen along the Tubu watershed. This could be the premise of a Punan sub-district in Malinau. To the local government, it could be part of the larger plan of turning the district into a 'conservation district'. The first, and perhaps and most problematic step, would be to reach a consensus amongthe Punan Tubu themselves.

\section{REFERENCES}

Andersen, U., and Kamelarczyk, K. 2004. 'Implications of small-scale timber concessions on rural livelihoods - a case study from the Malinau district, Indonesia.' Master Thesis, Danish Centre for Forest, Landscape and Planning, Royal Veterinary and Agricultural University, Copenhagen.

Bahuchet, S., Grenand, F., Grenand, P. and de Maret, P..2000. Les peuples des forêts tropicales aujourd'hui. Forêts des tropiques, forêts anthropiques. Sociodiversité, biodiversité: un guide pratique. APFT, Bruxelles, 132 pp.

Byron, N. and Arnold M. 1999. 'What futures for the people of the tropical forests?' World Development, 27(5): pp. 789-805.

Dounias, E. and Froment, A. 2006. 'When forestbased hunter-gatherers become sedentary: consequences for diet and health.' Unasylva 224, 57(2) : pp. 26-33.

Dounias, E., Selzner, A., Koizumi, M. and P. Levang. 2007. 'From sago to rice, from forest to town. The consequences of sedentarization on the nutritional ecology of Punan former hunter-gatherers of Borneo.' Food and Nutrition Bulletin 28(2).

Kurniawan, I., 2003. Kajian kelembagaan jaringan pemasaran hasil hutan di Kalimantan Timur. MSc thesis, IPB, Bogor, Indonesia.

Levang, P., 2002. 'People's dependencies on forests.' In Technical report phase 1, 1997 2001. ITTO Project PD 12/97 rev. 1 (F) Forest, Science and Sustainability: the Bulungan Model Forest. Bogor, CIFOR and ITTO: pp. 109-130. 
Levang, P., Dounias, E. and Sitorus, S. 2005a. 'Out of the forest, out of poverty?' Forests, Trees and Livelihoods, 15: pp. 211-35.

Levang P., Buyse, N., Sitorus, S. and Dounias, E. 2005b. 'Impact de la décentralisation sur la gestion des ressources forestières en Indonésie. Etudes de cas à Kalimantan-Est.' Anthropologie et Sociétés, 29 (1): pp. 81102.

Levang, P., Sitorus, S. and Dounias, E. 2007. 'City life in the midst of the forest: A Punan hunter-gatherer's vision of conservation and development.' Ecology and Society 12 (1): 18. Online: http://www.ecologyandsociety. org/vol12/iss 1/art18/

Pradhan M., Suryahadi, A., Sumarto, S. and Pritchett, L. 2001. 'Eating like which "Joneses?" An iterative solution to the choice of a poverty line "reference group".' Review of Income and Wealth 47 (4): pp. 473-87.
Shackleton, S.E., 2005. The significance of local level trade in natural resource products for livelihoods and poverty alleviation in South Africa. PhD thesis, Rhodes University, Grahamstown. 286 pp.

Sitorus, S., 2004. Politik-ekonomi desentralisasi pengusahaan hutan: studi kasus IPPK di Kabupaten Berau Kalimantan Timur. MSc thesis, IPB, Bogor, Indonesia.

Sitorus, S., Levang, P., Dounias, E., Mamung, D. and Abot, D. 2004. Potret Punan Kalimantan Timur. Sensus Punan 2002-2003. Bogor, CIFOR - IRD, 39 pp.

Wong, G.Y. and Godoy, R. 2003. 'Consumption and variability among foragers and horticulturists in the rainforest of Honduras.' World Development, 31(8): pp.1405-19. 


\section{CHAPTER 3 \\ EXAMINING THE CONSERVATION SIGNIFICANCE OF LOCAL PEOPLES' PERCEPTIONS AND USES OF DIFFERENT FORESTED LANDSCAPES ${ }^{1}$}

Douglas Sheil, Michael Padmanaba, Miriam van Heist, Imam Basuki, Nining Liswanti, Meilinda Wan, Rajindra Puri, Rukmiyati, Ike Rachmatika and Ismayadi Samsoedin

${ }^{1}$ This chapter is based on two publications: Sheil et al. (2006) and Padmanaba and Sheil (2007): see references. 


\section{INTRODUCTION}

There is much soul searching on how to achieve conservation in the tropics (Kramer et al., 1997; Brandon et al., 1998; Terborgh et al., 2002). Decision-makers in many tropical countries view conservation as something imposed by rich countries and foreigners. Conservation is rarely viewed as a significant local priority and often remains dependent on donor support and pressure.

Additionally, various spokespersons for global conservation continue to see local people as a problem (Redford, 1991; Redford and Stearman, 1993; Alvard, 1995; Ghimire and Pimbert, 1997; Terborgh et al., 2002; Mittermeier et al., 2003). Conservationists rarely seek genuine allegiances with local people, yet we believe that declining biodiversity and the poverty and marginalisation of remote communities are often connected. In particular, forestdependent people often suffer from the same development decisions that damage forests. These connections are even more apparent with decentralisation policies, i.e. the future of the forest and of the forest peoples themselves is more and more in their local hands. However, a perceived failure of integrated conservation and development projects and community-based conservation efforts (Wilhusen et al., 2002) has led to calls for a return to a protectionist conservation paradigm (e.g. Terborgh, 1999; Oates, 1999; Terborgh et al., 2002).

Decision-makers are faced with diverse stakeholder demands. The interests of some, such as commercial enterprises, are clear and easily communicated. On the other hand, the aspirations of local communities and their responses to externally driven conservation interventions may remain hidden unless specific efforts are made to solicit them (Scott, 1998). Inaccessibility, language barriers, economic marginality and prejudices against them make such consultation harder.

While indigenous knowledge and development issues are increasingly recognised, local preferences and responses remain neglected (Sharpe, 1998). This is critical, for if local views remain unknown, any conservation interventions are likely to overlook both opportunities for collaboration and the pitfalls of predictable conflicts. What is needed is an understanding of local views and a means to make these more

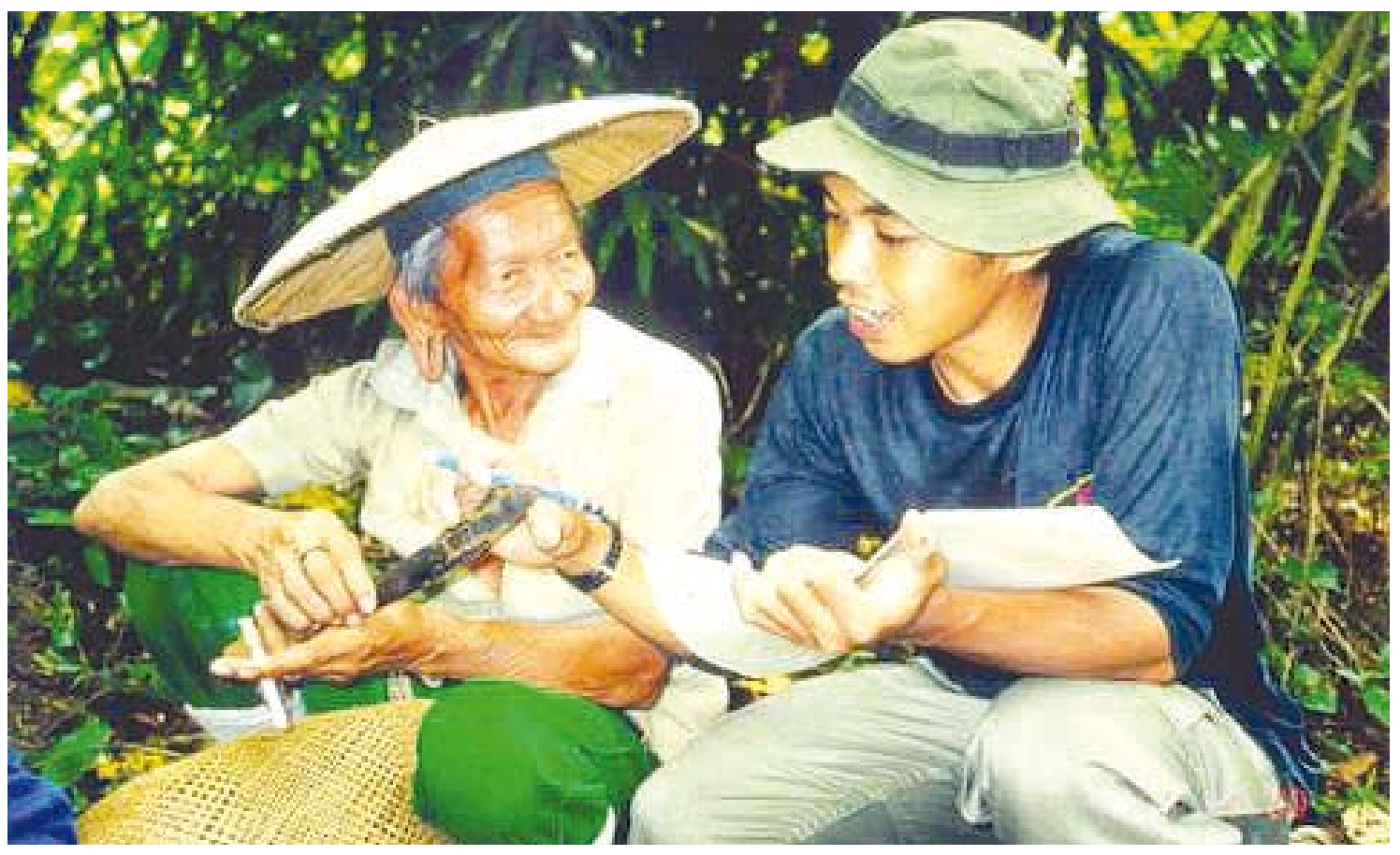

Pak Aran Ngau (Langap Village) and Imam Basuki (CIFOR) discusses how they can judge the value of Malinau's soils (Photo by Douglas Sheil) 
influential. Tapping into this realm of values and attitudes does not guarantee effective conservation, but it may help tip the balance (Uphoff and Langholz, 1998).

The purpose of this chapter is to provide an overview of our research with seven communities in and around the Malinau Research Forest, where we explicitly set out to identify and clarify local views and priorities with regard to forest landscapes and biodiversity, and to assess responses to conservation information campaigns. We do not attempt a detailed overview of the methods themselves (see Sheil et al., 2003; Padmanaba and Sheil, 2006); rather we set out to illustrate why asking local views is valuable within the context of decentralisation of planning and management, especially to those whose primary interests concern conservation. The work takes five main themes: i) asking what occurs where (as in classical biodiversity assessments); ii) asking why it matters to local communities; iii) evaluating implications and possible courses of action or diagnoses; iv) sharing insights and implications with communities, stakeholders and decision-makers; and v) assessing stakeholder feedback. We shall touch all of these, but will emphasise the second and fifth, because these aspects are missing in so many research and survey activities where they could easily be included. Mutual understanding facilitates dialogue among researchers, policymakers, forest communities, conservationists and others on the significance of forested landscapes and the roles they perform.

In terms of policy responses, we believe that conservation values should not be sought exclusively in large protected areas, and should not be the sole preserve of professional conservationists. We believe that it is possible to maintain considerable biodiversity in areas used for other purposes by gaining the cooperation and guidance of local people, timber managers and others (Warren et al., 1995; Shanley and Gaia, 2002; Hutton and Leader-Williams, 2003). We do not refute Western biocentric arguments for protected areas; rather, we see local involvement as a pragmatic and ethical means to foster a new constituency and to achieve conservation across a wider landscape. Neither do we wish to neglect so-called 'less-useful' species. We find that the concerns of local people are not exclusively utilitarian; their landscapes are much more than a larder of raw materials and services, and they resonate with culture, heritage and even recreation (Posey, 2000). In essence, we propose that conservation can be built around what local people find important.

\section{APPROACH AND METHODS}

\section{Assessing local uses and preferences}

Our multidisciplinary approach was developed during a study with seven communities in the Malinau watershed. We chose to work with the Merap and Punan because they represent distinct local cultures. The Merap are a politically influential group in the local context, with affinities to the regionally powerful Kenyah. The Punan have been less politically visible. The primary difference between the two groups, at least until very recently, is the emphasis that the Merap place on swidden (dryland) rice farming, whereas the Punan have specialised in extractive forest-based activities. The data-collection phase within each community was approximately three to four weeks, although follow-up visits occurred beyond this period.

We sought to identify and understand what local people find important. Thus, despite our biodiversity-survey emphasis, importance was not limited to natural resources and economic values in any conventional sense. Things can matter for reasons other than utility or trade (Posey, 2000; Sheil and Wunder, 2002). Various community-focused methods provided a framework for identifying, discussing and scoring the significance of local land types, sites, species and resources (Table 1).

A closely linked field survey assessed different vegetation types and features across the wider landscape. Two hundred field plots were established and described, for which we catalogued information on location, soil, vegetation, site use, local plant names and potential for cultivation (Sheil et al., 2003). More than 15,000 plants were recorded, representing more than 2,000 distinct species, some new to science. Local informants attached 1,457 unique species-use combinations to these. 
Table 1. Data collection techniques for multidisciplinary landscape assessment study

\begin{tabular}{|c|c|c|}
\hline Broad approach & Method/target audience & Variables/data collected \\
\hline \multirow{2}{*}{$\begin{array}{l}\text { Community } \\
\text { meetings }\end{array}$} & Mapping & Identification of land and forest types \\
\hline & Inventory & Identification of forest products \\
\hline \multirow{6}{*}{$\begin{array}{l}\text { Key informant } \\
\text { interviews }\end{array}$} & Village head only & Village description /perspective on land use \\
\hline & Traditional leader only & Cultural background to land use \\
\hline & Village head and Traditional leader & $\begin{array}{l}\text { Settlement history and land use } \\
\text { Disasters and important events }\end{array}$ \\
\hline & Shopkeepers & Price of traded goods \\
\hline & General key informants (3-5) & Traditional knowledge of land use \\
\hline & Forest users $(3-5)$ & Forest product collection and sale \\
\hline \multirow[t]{2}{*}{$\begin{array}{l}\text { Household } \\
\text { surveys }\end{array}$} & $\begin{array}{l}\text { Household census and } \\
\text { documentation from village }\end{array}$ & Demography \\
\hline & $\begin{array}{l}\text { Interviews with heads of at least } 30 \\
\text { hhs; open and closed questions }\end{array}$ & $\begin{array}{l}\text { Hh profile, attitudes, perspectives, } \\
\text { comments of problems and solutions }\end{array}$ \\
\hline \multirow{5}{*}{$\begin{array}{l}\text { Focus group } \\
\text { discussions }\end{array}$} & Women/men; old/young separately & Scoring importance of landscape units \\
\hline & Women/men; old/young separately & $\begin{array}{l}\text { Sorting changes in importance of } \\
\text { landscape units and natural resources over } \\
\text { time }\end{array}$ \\
\hline & Women/men; old/young separately & $\begin{array}{l}\text { Scoring of how distance of landscape units } \\
\text { influences importance }\end{array}$ \\
\hline & Women/men; old/young separately & $\begin{array}{l}\text { Scoring of importance of different sources } \\
\text { of products }\end{array}$ \\
\hline & Women/men; old/young separately & $\begin{array}{l}\text { Scoring of most important species per use } \\
\text { category }\end{array}$ \\
\hline
\end{tabular}

Ownership of local knowledge was addressed, because the potential exploitation of medicinal knowledge and locations of valuable resources pose concerns. All community members were informed about our intentions and goals regarding data collection. We emphasised that they need not tell us anything they did not want to. We never requested or recorded details of how medicinal plants were prepared and administered.

Given constraints of limited time and funding for field research, and a desire to cover a large area, we emphasised rapid methods. Community meetings and joint mapping exercises elicited local landscape classification and terminology, and clarified the geography of resource use. The maps provided a basis for our field survey; many plots were sited in unusual locations that would not have been easily found by outsiders. Maps were revised and clarified together over the study period.
We also relied on local informants to help define the various types or categories of value - for example, food, medicine, recreation - they attach to their land and resources, and to assess the importance of locations, plants and animals for each of these. For this purpose, focus groups and joint scoring exercises allowed a consensus to develop among informants. Sometimes follow-up discussions were needed to clarify understanding of these choices. For example, we initially wondered why respondents in the village of Langap preferred to value many medicinal plants as 'products to sell' rather than as 'medicine'. We learned that this village possesses highly regarded herbal expertise - it is a point of local pride that they provide remedies to other communities. Cross-checking of information with informants was performed through both formal and informal means. Overall, the scoring approaches resulted in consistent and credible results, as discussed by Sheil and Liswanti (2006). 


\section{Determining local responses to conservation information}

Based on the results of the surveys, we developed four posters written in simple Indonesian, yet the ideas are not oversimplified. Each contains a richly illustrated assortment of information. Plasticised against moisture, they should last for years and can be returned to over time, like an 'open book'. In brief, Poster-1 outlines why and how the original surveys were conducted. The poster emphasises local perspectives, but also explains why outsiders are concerned about Malinau's forests. Poster-2 is about the 'most important' local land types. It focuses on forests and rivers, explains threats and identifies locally important 'special places'. Poster-3 considers land use, including traditional cultivation and options for commercial crops. Poster-4 focuses on important species for building, food and various other uses and values. After several reviews and revisions with the communities, and a review with local government staff (the local government was asked to endorse the posters, which it did with only one minor change), we finalised, printed and distributed just under 4,000 posters to individuals, communities, schools, shops, churches, company offices and government buildings throughout the district. We encouraged recipients to display these posters in prominent positions. As we had hoped, these posters were popular and are now widely displayed in the region.

Prior to distribution of the posters we undertook a survey of 54 respondents to assess their background knowledge of the issues portrayed in the posters (already informed by the wider village surveys). We selected a small number of respondents from Malinau Town and seven local villages, stratified by location, age, gender and occupation, to obtain satisfactory coverage by background. Before this study, only half the respondents from the seven villages were involved in the original data collection surveys or in the subsequent poster review process. Timber and mining company staff were approached but only one (of five) was willing to be interviewed. No other individuals refused. This may bias respondents to those sympathetic to our aims,

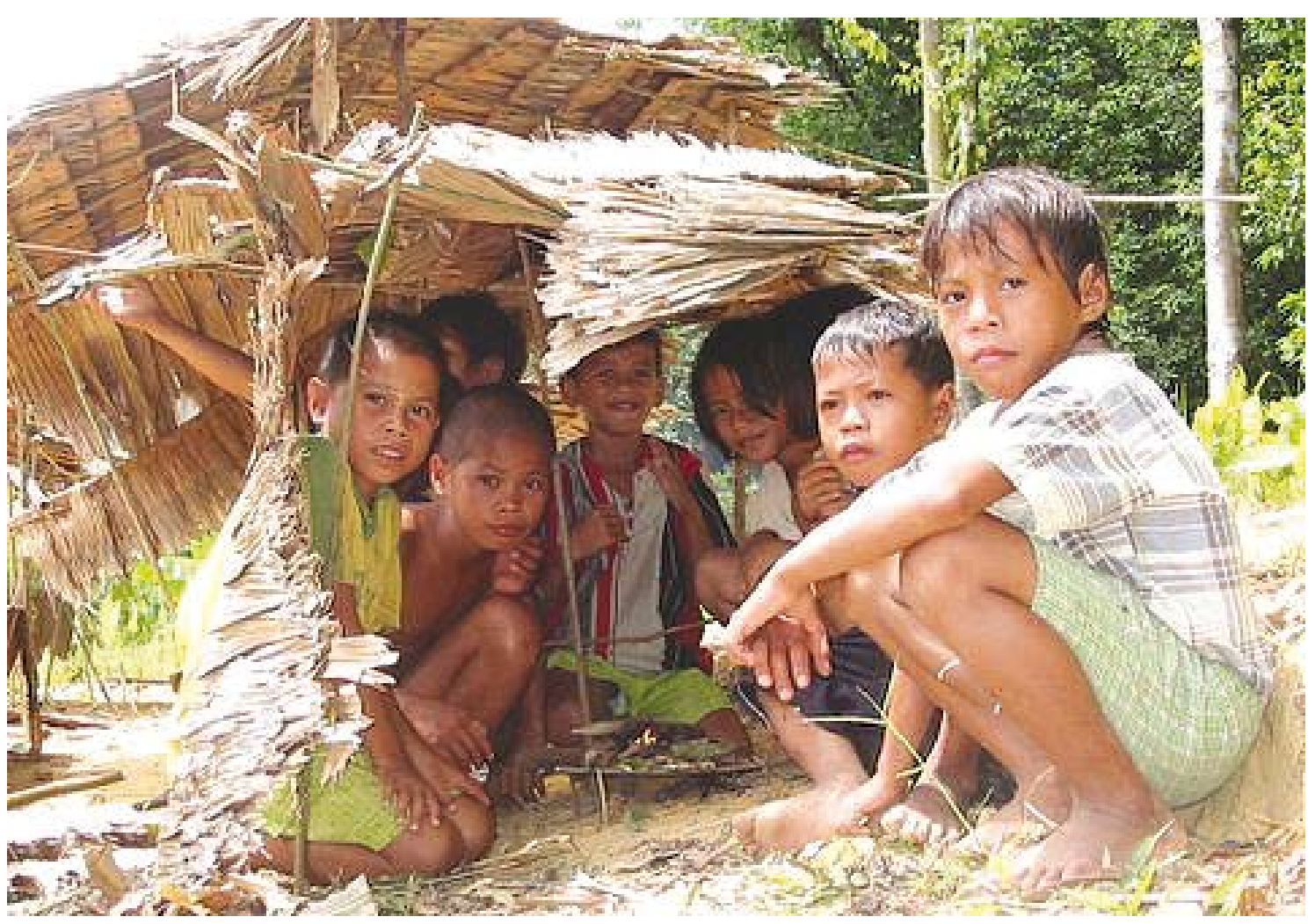

Punan children in Long Jalan play in the forest. They already know how to use and value many forest species (Photo by Douglas Sheil) 
though we have no reason to believe any such bias is large or significant.

Two months after distribution of the posters, the same respondents were re-interviewed. Three were unavailable for the second round and are excluded from our analyses (the final sample was 26 male and 25 female). All respondents were literate but $69 \%$ had not progressed beyond junior school. The questionnaire comprised of three sections. Part A assessed each respondent (gender, age, education, ethnic group, occupation). We scored 'forest reliance' by counting respondents who (a) 'go to the forest more than once a month' and (b) 'use river water for their basic needs'. 'Access to information' was scored by counting respondents who (a) 'own a television and/or radio' and (b) state that 'they often watch or listen to the news'. In each case, population summaries were calculated by adding the 'yes' scores, dividing by twice the number of respondents, and then multiplying by 100. In most overviews, we divided respondents into three primary groups: 'study villages' (from communities involved in the original datagathering study), non-study villages, and those from town, i.e. Malinau, the district capital.

Part B gauged agreement with 26 statements concerning information on the posters. The statements ranged from well-known to more obscure topics. Respondents had five choices: 'strongly agree'; 'agree'; 'disagree'; 'strongly disagree'; and 'don't know'. On suspicion that 'agreement' is culturally easier and could lead to biased responses, we mixed 'true' and 'false' statements. We classified statements into two groups: 'insider' (those where we explicitly reflect local views or would expect respondents to have the necessary information locally), and 'other' statements (outsider analyses, or contextual knowledge such as global setting). Questions consistently answered the same by all respondents will not reveal change, so some questions were made 'harder and more vague' to ensure some variation. One statement was omitted from analysis because initial examination suggested it had proved overly confusing.

Part $\mathrm{C}$ explored local opinions on conservation, using 10 specific, open-ended questions. In this open-ended format, differences before and after poster exposure are unstructured and do not necessarily represent a change in view as respondents were often eager to finish the interview.

Our analyses summarised answers before and after respondents received posters. We scored responses as 'correct' if they confirmed poster content: i.e. 'agree' with confirming a poster statement or 'disagree' with a contradictory statement. The score was expressed as a percentage, representing our 'measure of agreement'. This does not measure percentage agreement with overall poster content, but rather is intended as a sensitive index of agreement and uncertainty.

We assessed the probability of observed changes in responses occurring due to chance by assuming that respondents (not questions) are independent. The binomial distribution (implemented in Microsoft ${ }^{\circledR}$ Excel) provides the exact (one-sided) probability of obtaining the number of changes seen in the expected direction (e.g. decreased 'don't know' answers or increased measure of agreement), if changes were in fact randomly signed. We assume our posters account for significantly different responses between the first and second interviews.

\section{RESULTS}

\section{Local uses and preferences}

The results are rich and multifaceted. Here we present some summary illustrations. Using consistent classes of importance allows us to summarise the data collected across the different exercises in the seven communities. Summaries can be made about various key value classes, including food, medicine, light and heavy construction, ritual and decorative tools, boats, crafts, recreation, etc. We will illustrate this for hunting, which concerns three of our primary value classes: species used for hunting tools; those valued as providing good locations for hunting; and what people wish to eat.

Local uses and needs from different landscapes An understanding of local views suggests the need for improvements to current forestry practices. All sections of the communities considered unlogged forest as the most important land type, 


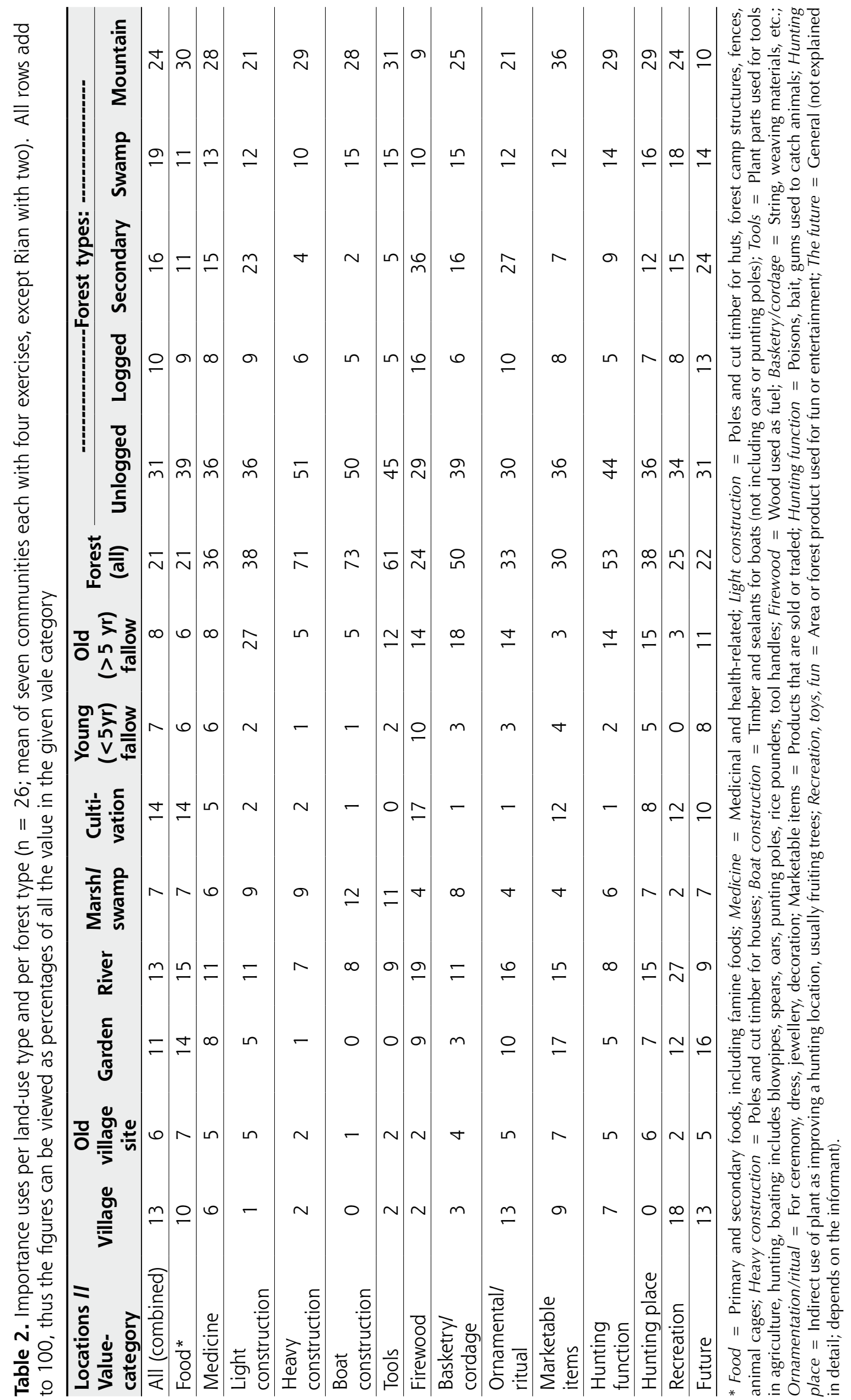


both in general and for almost all classes of value and use that we assessed; logged forest is given a much lower preference (Table 2). Timberharvesting regulations (TPTI - the Indonesian Selective Logging and Planting system) require concession holders to slash all undergrowth and climbers each year for five years after felling. This is intended to reduce aggressive weeds that might impede regeneration. In practice, however, many useful species are cut, including rattan canes and timber seedlings, as well as plants that serve as medicinals, foods, craft materials and food for valued wildlife. Even if applied properly, the silvicultural benefits are limited, whereas the impacts on biodiversity and communities are considerable. This slashing is implemented concession-wide, even on rugged terrain where logging is impractical and may be more damaging than the harvesting itself. We have suggested that this policy be reviewed (Sheil et al., 2003; Sist et al., 2003).

Timber species rate as the most important of all species considered by communities in our exercises. At the very top is ulin (Eusideroxylon zwageri), a durable construction timber with a number of other uses. Technically, companies are not allowed to log ulin, but enforcement is lacking. Other preferred timber species (kapur, Dryobalanops lanceolata; meranti, Shorea spp.) are also valued by logging companies, and a shortage of preferred construction materials is already occurring in many local communities. One community, Paya Seturan, has responded with an internal agreement to keep an area of local forest cover as a community resource, thereby promoting a de facto protected area. Sites need to be located up river as timber is floated downstream. Unfortunately, such local reserves have no official recognition and are threatened by both official concessions and increasing timber demands from less fortunate villages.

Many remote Punan groups cultivate relatively little and are regularly dependent on wild food resources such as palm starch (sago). Other ethnic groups also rely on these palms during occasional crop failures due to droughts and floods; all villages reported several such events within living memory. In primary forest, the palms are common enough and are protected by community-management practices (Puri, 1997b). However, they are rare in logged forest.
The primary local sago palm (Eugeissona utilis) tends to grow along ridge tops, and this is where heavy machinery is used to extract logs on the steeply undulating local terrain - normal practice endorsed in 'reduced impact logging' due to erosion and safety benefits (Sist et al., 2003). Machine access destroys the palms. Concerns about this food resource might be addressed by modifying skid-trail design to reduce damage to the palms, or indeed by programmes to improve food security.

Such information often appears so commonsensical that once it is highlighted, it may appear that such results must be trivial to gather and comprehend. Unfortunately, it is not quite so simple. Reliance on sago, for example, has been strongly stigmatised as being symbolic of backwardness, to the point at which communities are ashamed to discuss it. When talking to outsiders, community representatives, who are often the wealthier members, will say that sago was 'only eaten in the old days' even though this is untrue. It is only through using a combination of approaches that these discrepancies are identified and then examined.

There are other instances of hidden values, and some pose even greater difficulties to uncover. For example, many (though not all) Punan groups traditionally buried their dead in large ceramic jars, which are very valuable now and are often stolen. Such sites are secret, to provide protection. Many outsiders still believe that the Punan merely leave their dead in the forest; a myth that the Punan themselves have been happy to perpetuate. However, the destruction of such grave sites during timber concession development has recently become a concern. Logging has also destroyed Merap grave sites. Traditionally an area of about a hectare or more surrounds each grave site, often surviving as remnant forest groves - even in more intensively cultivated areas. Graves (Merap and Punan) are taboo to all forest-product collectors. The destruction of forest grave sites by concession holders remains a major cause of resentment between communities and companies. Protecting such sites would seem uncontroversial and easy to implement. It would not only provide small forest refuge areas with conservation significance, but at the same time would help avoid the local conflict and discontent that currently threatens 
community/company relationships. Such a simple step would indicate a change in attitude, and offer a basis for further improvements.

Local priorities, although relatively uncontroversial once elicited, are rarely clear in advance to outsiders. The examples described above represent only a fraction of the information we have documented about how local communities relate to their environment. All were uncovered through a process of identifying what is important locally, through various interactive exercises. With this knowledge, we can seek land-use options that better reflect local needs and conservation goals.

\section{Soils and Land-use}

Although we focused on finding out what was important from a local perspective, we also considered some land development options of local relevance. Our soil data helped clarify the potential for various commercial crops that are commonly mentioned as having potential in the wider region. The soils encountered were diverse, but chemical analyses showed that nutrient levels were consistently low, while aluminium toxicity, hard-pans, erosion-vulnerable soils and steep terrain further limit cultivation opportunities. According to local perceptions, the best soils are found primarily on the limited alluvial plains. These views are consistent with our textbookbased evaluations; indeed, these assessments also suggest the reason why regional population densities are so low.

A formal evaluation (involving national guidelines and criteria) of our 200 sample sites indicated that these are all unsuitable for sustainable production of cash crops such as pepper, coffee, cocoa, candlenut, rubber and oil palm; all of interest to local government. However, some alluvial areas have potential for sustained field rice and coconut cultivation. All the suitable sites identified are already under cultivation or fallow, and even these sites are not ideal, as nutrient status is low and flood risk appears high. Even with heavy application of artificial fertilisers there is little room for economically viable, large-scale agricultural expansion on such rugged and inappropriate land conditions. Sharing this understanding will be vitally important in avoiding ill-conceived developments. It appears then that the future well-being of the district depends largely on forests and how they are used.

\section{Focused Studies}

As we have shown, our approach not only allows us to ask what species and habitats occur where, but also whether they matter to local stakeholders, and if they do, how much and why they matter. This clarifies priorities and allows us to ask how these values are threatened and what might be required to maintain them. Such approaches need not be limited to large-scale multidisciplinary surveys, but can enrich more focused studies as well.

Collaborative fieldwork with local communities can benefit even those concerned primarily with more classical conservation biology (Sheil and Lawrence, 2004). During our work, we were faced with a rugged area of about 2,000 $\mathrm{km}^{2}$. Local people helped us develop maps showing and naming rivers, roads, villages, sources of sago and rattan, abandoned villages, hunting locations, caves and other special sites and resources (Figure 1). In studying the range of sites and habitats, local advice proved invaluable. But we wanted to go further.

We suspected that many special sites not only have significance for local people, but also contain restricted habitats and species, and so it turned out. For example, limestone outcrops provide a restricted habitat for valuable birds' nests (made by cave swiftlets, Aerodramus spp./ Collocalia spp. and prized for Chinese soups), but also for many other restricted species. We learned that Punan groups dispatched to guard these birds' nest caves had also planted dense stands of rattan, both to impede access to the area and to have a valuable forest product to trade with their farmer patrons. With local assistance, we sought out and clarified the status and background of such special locations. Generally, such sites, especially those in undisturbed habitats, added more unique species (some new to science) to our overall survey than did the more typical sites. Thus, locating such sites, which is dependent on local guidance, provides more effective biodiversity inventories.

In addition to the main surveys introduced above, we have also undertaken smaller studies, addressing specific topics. Fish, for example, 


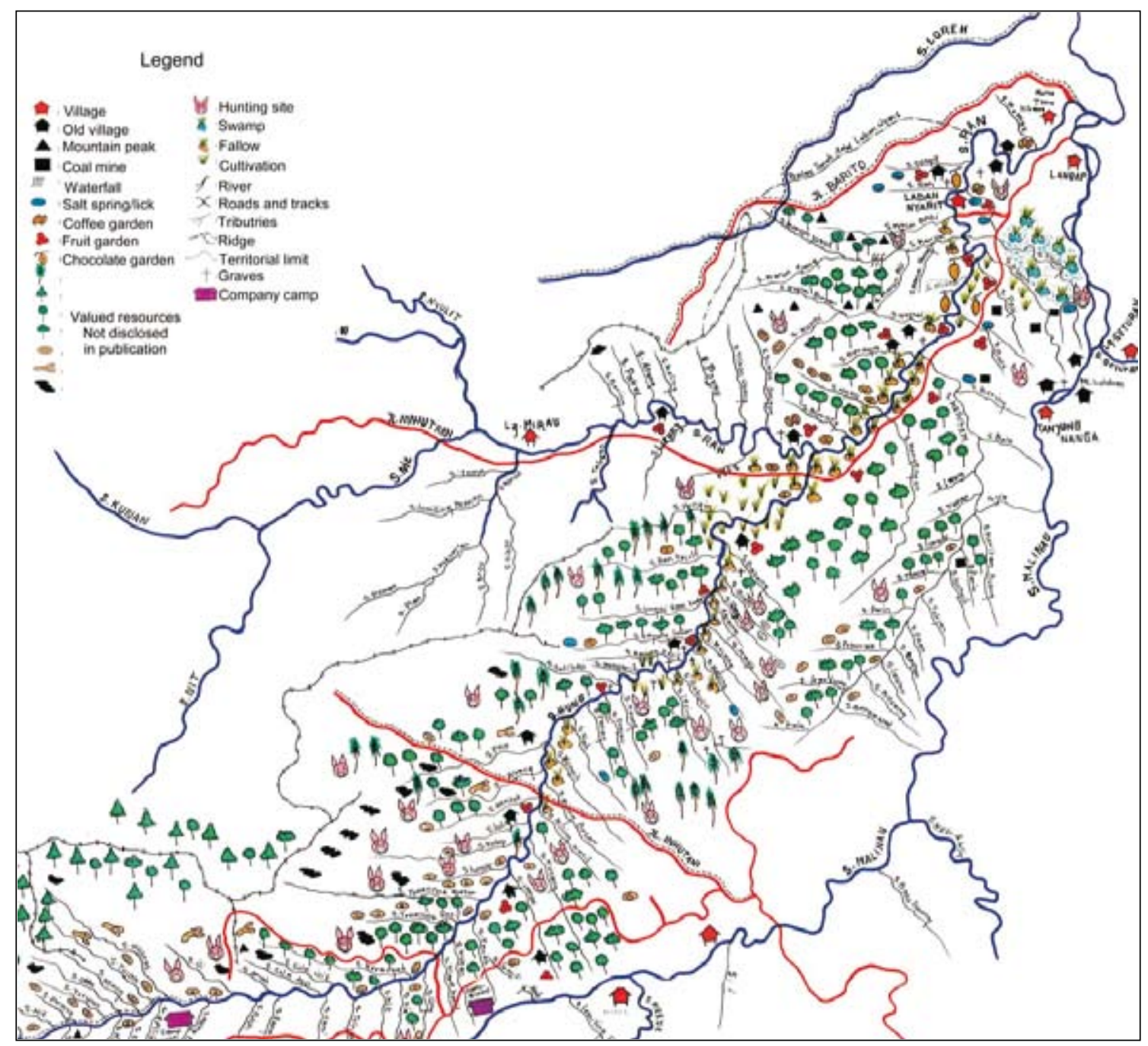

Figure 1. Example of detail revealed in part of a community map, made with the Punan community of Laban Nyarit

are important as a source of animal protein, especially when pigs are scarce or the time available for hunting is reduced by farming activities (Puri, 1997a). Local people from three villages distinguished all but one of the 45 species recorded in the field survey (at least two are new to science) and ranked the most important ones. Among the fish most preferred for local consumption are two species of river carp (Tor spp.), which also have cultural significance. Tor are primarily plant eaters; they eat algae that grow on rock surfaces in sediment-free rivers, and the fallen fruits and flowers of trees (e.g. Dipterocarpus and Ficus) growing along the riverbank (Sulastri et al., 1985). The adults occur in deep, clear pools in the forest, whereas the juveniles live in shallower tributaries. Our survey did not find these fish in rivers affected by siltation from forest cutting or road building, or in more open areas generally. These fish appear vulnerable: they require clear water, are dependent on forest vegetation, have a relatively low reproductive rate, are keenly sought and easily caught. Recognising that such species are vulnerable to forest change can help inform forest management and land-use choices.

Hunting is another important source of animal protein and animal fat. Animal fats are scarce in the local diet and highly valued and sought after (Puri, 1997a). Hunting still plays a significant role in the area. Out of all sources of animals, including purchased and farmed items, wild species contribute more than half $(58 \%)$ of 
what people rated as important. In remote communities such as the Punan village of Long Jalan, the importance of wild species reaches $81 \%$. In downstream farming communities, domestic animals and trade are judged more significant, although wild animals remain important (45\%).

The hunting function class (Table 2) refers to items needed to hunt effectively. This includes plants and plant parts used for constructing hunting tools. Mature forests contribute more than half the total importance associated with all species identified in this class. Of 115 relevant plant uses recorded in this class during the field survey, 12 were said to be unique to a given species. The most useful plants were all trees or palms, with the most important species being the tree Antiaris toxicaria (Moraceae), with its poisonous latex used for blowpipe darts. We thought this was surprising, given the visible trend to hunt with dogs, spears and shotguns (the latter methods are widespread, yet technically illegal). While some Punan still regularly hunt with darts, the majority of blowpipes are today used primarily in festival day competitions. The high score seems to reflect a desire to preserve species with historical and symbolic value, and a backup hunting technique. Only one animal was recorded in this role: the feared king cobra, Ophiophagus hannah. Although one Punan group noted its value for dart poison, it is not viewed as important as it was associated with warfare in the past (E. Dounias pers. comm., 2004).

The hunting-place value category refers to the locations preferred for hunting. Although hunting occurs in all habitats when the opportunity arises, forests, especially unlogged, and remote mountain areas are rated the most important. The most important species (primarily Dipterocarpus trees, oaks, figs and palms) yield fruit that attract animals. Some Punan informants implied that one of the values of cultivation was that rice and cassava draw animals into open areas where they can be hunted. However, these animals still depend on the forest; the fields serve as bait. Five hundred and eighteen plant species recorded in the field survey were said to provide value by supporting and attracting wildlife.
In terms of locations good for hunting, 'salt springs' (sources of salts or detoxifying clays, or both (Krishnamani and Mahaney, 2000)) visited by deer, pigs, monkeys and birds also provided a key role, as did some former or abandoned village areas where the concentration of planted fruit trees was an attraction. Logging, and especially understorey cutting (see later), was said to degrade habitat suitability for hunting, as most valued species decline in these areas. In addition, after logging, debris and tangles make access physically difficult, and the right to hunt in active concession areas is unclear.

The most valued food resource and the primary focus for hunting is the bearded pig (Sus barbatus). Pigs provide the bulk of vital animal fats and proteins in people's diet. According to local people, numbers of these migratory animals usually decline in logged areas. This is credible; not only does the cutting, road building and associated noise drive away animals, but the slashing also removes herbaceous food. Timber cutting specifically removes many of the larger fruiting species (e.g. dipterocarps and tropical oaks) that are known to attract pigs in the fruit season (see also Curran and Webb, 2000). When there are fewer pigs, the communities are forced to find other ways to supplement their diets. Eating of less-preferred and often protected species, such as monkeys, appears more common in active concession areas (Puri, 1992). We have also encouraged and guided a doctoral study on the ecology of these animals (near completion).

\section{Determining local responses to conservation information}

Now we turn to the question of whether the process of sharing results from the surveys had any impact. After the feedback information posters were distributed, the number of 'don't

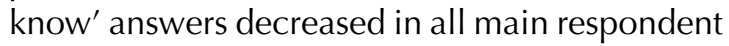
categories (Table 3). Overall, 35 respondents gave 98 'don't know' answers before they received the posters, and afterwards this had decreased to 38 'don't know' answers from 26 respondents. The improvement in knowledge per respondent was significantly different from what would be expected by chance overall $(p<$ $0.001)$, in study villages $(p<0.01)$ and in the non-study villages $(p<0.005)$. In the town there 
Table 3. Differences in group responses before and two months after information poster distribution

\begin{tabular}{lcccccc}
\hline & \multicolumn{2}{c}{ Study villages } & Non-study villages & \multicolumn{2}{c}{ Town } \\
\cline { 2 - 7 } & Before & After & Before & After & Before & After \\
\hline Sum 'don't know' responses & 38 & 17 & 39 & 9 & 21 & 12 \\
\hline $\begin{array}{l}\text { Overall agreement with poster } \\
\text { information (\%) }\end{array}$ & 78.0 & 80.5 & 73.4 & 80.6 & 79.3 & 86.2 \\
\hline Insider views and knowledge (\%) & 86.0 & 87.6 & 83.7 & 88.8 & 83.8 & 87.7 \\
\hline Other views and knowledge (\%) & 67.8 & 71.3 & 60.4 & 70.1 & 73.6 & 84.3 \\
\hline
\end{tabular}

was only a $9 \%$ likelihood that the improvement would have been noted by chance alone.

Agreement with poster content was high. Differences between villagers and town dwellers are relatively small (Table 3 ). Two months after receiving posters, the average agreement had increased in all three categories. The change in agreement was positive for 36 respondents, and negative or unchanged for 15; the binomial tests show that these patterns are significant overall $(p<0.001)$, in non-study villages $(p<0.001)$ and in the town $(p<0.01)$. In the study villages the data implies only a $16 \%$ probability that the posters had no positive effect.

Differences are small but (as expected) study villages show a slightly stronger initial agreement on 'insider views' (Table 3). Considering statements reflecting non-insider information, town dwellers had the highest agreement (again, as expected). However, the agreement and increase in all respondents' understanding in both statement classes is striking (Figure 2).

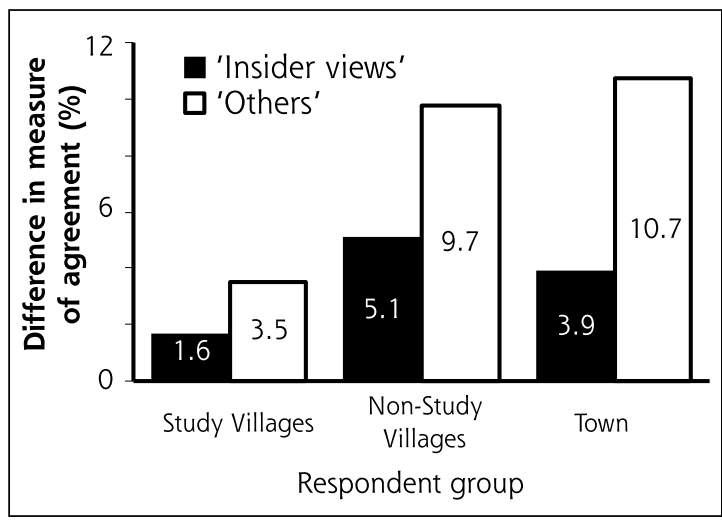

Figure 2: Change in average agreement, by group, for 'insider' '(black) and 'other' (white) classes of information two months after poster distribution. Change is positive for all six comparisons.
One subset of specific interest is the civil servants: all six increased their agreement with content after seeing the posters (binomial probability=0.016). They had a high initial agreement with 'insider views', but still showed a mean rise of $6 \%$ points $(83.3 \%$ before to $89.3 \%$ after poster distribution). Agreement with 'other' information started lower but climbed by $15.3 \%$ points $(63.9 \%$ before to $79.2 \%$ after poster distribution).

Respondents understood and agreed with most statements in the questionnaire. Of the total of 25, 12 statements regarding content were answered correctly by all respondents in all exchanges. An additional six statements gained $100 \%$ agreement after poster distribution. Several questions proved especially informative. Six questions initially received 'don't know' answers from more than five respondents; all involved statements regarding 'other views'. These included several statements on the wider conservation significance of the region, including for example: 'There are many plants and animals in Malinau that are not found in most other parts of the world' - true (before $=16$ don't know answers; after=8); and 'The forest of Malinau is not outstanding as there are many other forests in the world' -false (before $=12$ don't knows; after=9).

One especially significant statement, 'most areas in upper Malinau are not suitable for permanent crops such as oil palm, pepper and cacao', received 12 'don't know' answers beforehand (and nine after) and most respondents (65\% before and $61 \%$ after poster distribution) actually disagreed.

\section{General views}

The interviews also probed opinions starting with an initial agree-or-disagree question. 
All said water quality was important enough to be considered in land-use planning. The majority suggested that clean, clear water was important for health. Also, all stated that land-use planning should recognise plant and animal conservation. A majority suggested this should lead to sustainable use of resources and keep wild animals and plants from extinction (before=19; after=31). One villager and one civil servant mentioned future ecotourism. All agreed that forests in Malinau need to be protected. Most suggested that uses must be sustainable, and nine (both interviews) considered this necessary to 'prevent disaster'. Three villagers wished to protect their resources from other villages.

Various forest areas were proposed for protection: village-owned forest or customary forest; upstream forests that were still intact; or even all forest in Malinau. A few civil servants answered that 'protected forests' should only be those 'legally recognised'. When asked who should be responsible for forest conservation, most respondents suggested that all stakeholders should be involved. Others, however, stated it was primarily the villagers' responsibility.

During the first interview, 29 respondents stated that logging companies were needed in Malinau and 22 disagreed. This ratio switched in the second interview. Those who want logging noted that companies were useful for jobs and income and other benefits. Others said companies destroyed forest resources and caused land degradation, and brought no benefits (six, both occasions). All respondents believed logging should be more strictly controlled. They suggested direct monitoring by village representatives $(n=43)$, or creating a team representing the main stakeholders (government, village representatives and a company officer) (six, both occasions). In addition, some civil servants, teachers, farmers and a company worker proposed improved enforcement of regulations and better agreements between villagers and timber companies. However, most respondents (41, both occasions) believe these companies remain a major threat, while illegal logging concerned nine (both occasions).

All respondents thought our posters were useful. In their view the posters increased local knowledge $(n=32)$, showed the importance of plants and animals (34), and for some respondents in the lower Malinau, they improved their knowledge of life upstream. The posters are viewed as most important for villagers (44); few respondents mentioned local government (4) or investors (3).

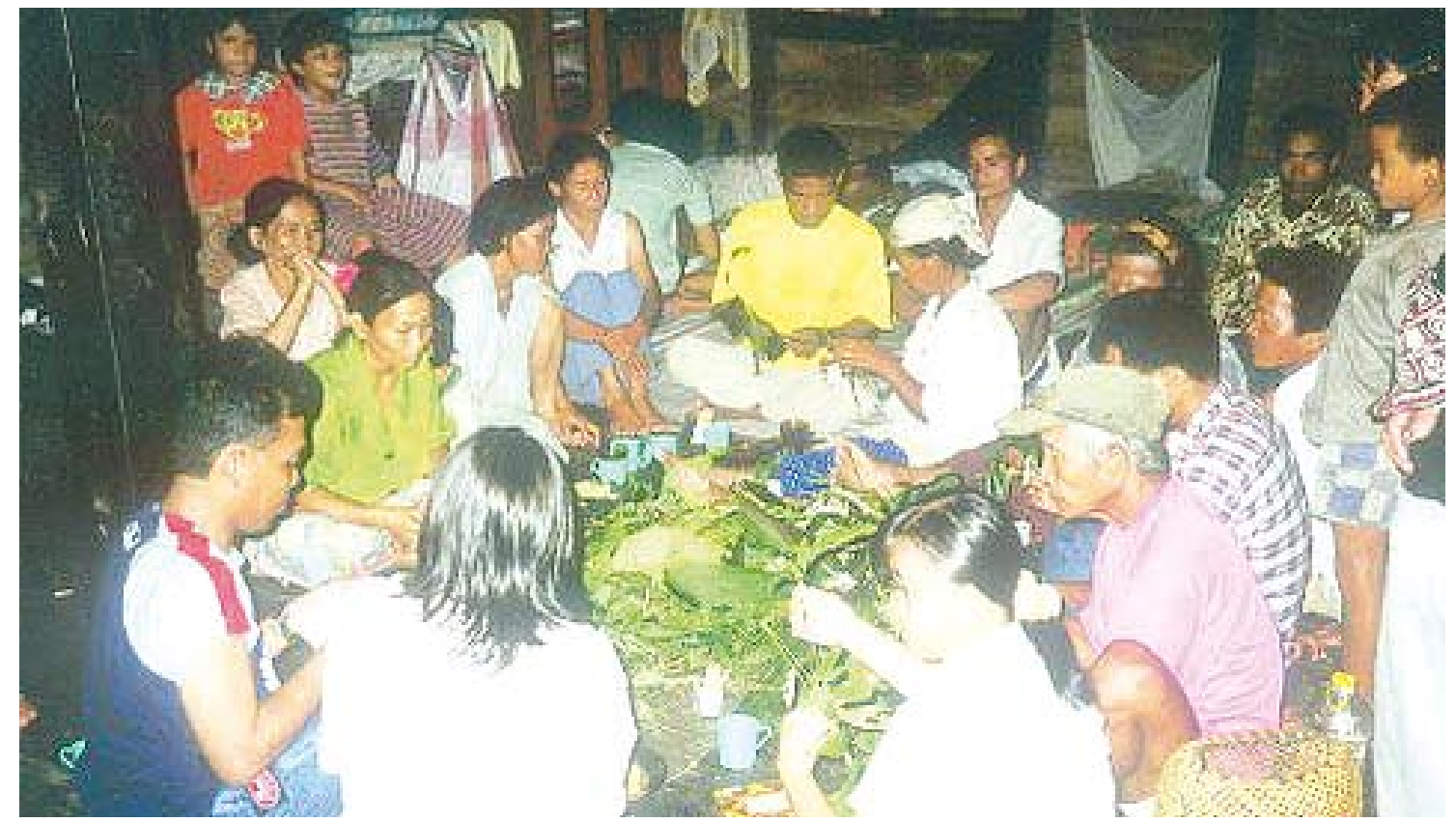

Plant review in Gong Solok village. Plant-use data required considerable cross checking as a quality control. Fortunately many villagers were enthusiastic to help (Photo by Douglas Sheil) 


\section{DISCUSSION}

\section{Scaling up}

Decision-makers prefer to focus on the general rather than the particular. A concern we have heard is the question, how can our approach be applied beyond the boundaries of our field sites and community maps? There are four responses to this:

- One should separate approach and results. While our general philosophy has wide relevance and applicability, many results may indeed be only locally relevant. What we seek to generalise and promote is an approach that can build on the needs and priorities of local communities.

- Although approaches such as ours can jumpstart consultation, there needs to be a genuine willingness to engage with and respond to local views and concerns.

- Decision-makers may indeed favour simple, one-size-fits-all solutions (Scott, 1998), but this may contribute to the very problems we are trying to address, i.e. neglecting specific local priorities and contexts in which they arise (Sulastri et al., 1985; Sheil and Wunder, 2002). The need to address problems in specific locations may be a challenge, but that does not absolve us of the need to do so.

- Finally, we may better ask, 'How can policy be better framed, or particularised, so as to address the priorities of real people in real places?' The development of local democracy allows some room for optimism. The biggest obstacles may appear to be the mindsets of policymakers (Dove, 1983; Dove, 1988), but many conservationists, too, could usefully adopt a new attitude.

\section{A new attitude}

We suggest everyone, including farmers, schoolchildren and others, must be seen as potential allies for conservation and improved land use. In return, they are entitled to anticipate that decisions address issues that they consider important. It could make a difference.

In Malinau, deforestation may continue with considerable environmental costs. Plantation projects will be implemented, but many will fail to be economically viable. Waterways will be choked with sediments. Conservation will become increasingly concentrated in a few guarded protected areas besieged by rising local demands. People will be increasingly alienated from the remaining forests, although they place considerable use value on the various forest habitats, in particular unlogged forest. In the quest for food security and viable livelihood options, many members of distant communities will be forced into an alien urban poverty or the government will be forced to subsidise local livelihoods.

But perhaps this is not inevitable. The region is rich in natural resources. By recognising and balancing local needs and priorities with other demands, we can envisage a future landscape that not only fuels a strong local economy, but also continues to provide some basic needs to people. This potentially requires an agreed zoning of the landscape where different types of activities, controls and management activities reflect wider needs and acceptable compromises. This landscape might maintain considerable forest cover, and many species of both local and more general conservation significance. Conservation can be viewed and implemented as a locally motivated process rather than merely a result of foreign and external pressures.

Attitudes must change at all levels, but especially at higher ones. Our poster survey indicates that knowledge levels can be readily increased, which will lead to more informed decision-making. Conservation priority-setting must reflect a larger cross-section of society, to reduce conflict and generate constructive new alliances and supportive constituencies. To help facilitate initial understanding, we believe methods such as ours have considerable value. We foresee their use in two ways: i) as part of larger conservation assessments - the addition of local insight adds little cost and can make surveys considerably more efficient, while also making the information relevant to many more stakeholders; and ii) as simple approaches for consultation and negotiation support.

What needs further attention is the transfer of information to decision-makers in a manner that will increase the decision-makers' attention and application. The costs and efficiency of such surveys, the skills required, information to be 
collected, and communication of the results also need further evaluation.

\section{Follow-up}

The full conservation significance of local information may not be grasped in a one-off generic information-gathering process. Followup activities can help build on local information and clarify the wider implications of maintaining the status of a given resource or location in a changing landscape. Such activities hinge on the nature of the local concerns, and their context. In brief, the research and consultation process identifies key concerns and likely problems, and helps identify acceptable solutions based on local circumstances, local knowledge and scientific understanding. This process should be iterative.

Our work underlines that local communities have complex relationships with their environment that need to be respected, understood and taken into account in all relevant decision-making and policymaking and their implementation (Chambers et al., 1989; Hobart, 1993). For Indonesia, this message requires a paradigm shift for all the institutions and processes related to forest management and conservation. There are opportunities for influence as decentralisation has opened up many issues for more localised scrutiny than was previously possible (Lutz and Caldecott, 1996; Colfer and Resosudarmo, 2002).

The dissemination of the main study results to local stakeholders via the posters clearly had an effect of improving understanding of local knowledge and the conservation significance of intact forest. They have also influenced perceptions of townsfolk and even local civil servants (Padmanaba and Sheil, 2007). Significantly these shifts were achieved by a relatively small and cheap activity, indicating that they could be more widely adopted in other regions too. Importantly the reception of our posters may be very different from many superficially similar conservation education efforts, as the bulk of the information presented comes from the local people themselves. Most poster content is neither obscure nor controversial: knowledge of and agreement with the content was high even before the posters were distributed. None the less, there was a decline in 'don't know' responses (increased knowledge) and increased agreement with poster messages after distribution. Increased agreement was statistically significant overall, in the non-study villages and in town. The increase among study village respondents was less marked, but many were already familiar with the content (directly and indirectly) as a result of our previous activities and had less to learn from the final posters. Does the reduction in 'don't know' responses reflect a change in knowledge or perhaps greater confidence in stating a viewpoint? It is likely to be a combination of both, reflecting greater understanding and/or a willingness to be associated with the poster concepts.

We have also printed and distributed several thousand packs of playing cards that present information on the 40 most important species defined on local views and also describe both the threats to their maintenance and possible conservation ideas. Both cards and posters include some factual information on local conservation significance as perceived by outsiders like ourselves (e.g. on Borneo's endemics, deforestation rates, etc.), information that has also been well received. We are still working with other groups to incorporate survey information into a locally relevant environmental education curriculum. Most recently, we have developed a documentary film to explain and discuss the relevance of our surveys in the local context.

The methods themselves are published in Indonesian, English, Spanish and French (Sheil et al., 2003), and further trials have been conducted in Bolivia, Cameroon and West Papua. There is ongoing work in the Philippines, Gabon and Vietnam. We have developed a multilingual website to share our experiences (www.cifor. cgiar.org/m/a), and various publications have been planned to address different audiences.

\section{Challenges for Malinau's future}

Our surveys, provide some grounds for optimism about the future in Malinau, but many threats and challenges remain. For example, the majority of respondents consider that the upper Malinau 'is suitable' for permanent plantation 
crops. Such plantation schemes are currently promoted by local government as desirable future developments. However, most of the upper Malinau is rugged and inaccessible. Steep slopes and thin, easily eroded soils dominate the area. Our analysis, based on field sampling of soils and the application of official Indonesian Government criteria, suggests that most land in the upper Malinau (200 out of 200 sample points) is not economically suited for sustainable largescale plantation crops such as oil palm, pepper, and cacao (Basuki and Sheil, 2005). Clearing the steep slopes in the upper Malinau would have considerable environmental costs.

So, why is there disagreement? People are not familiar with what is needed for successful plantations. In these remote regions, investors promote the supposed benefits and play down the potential risks of plantations. These investors seek permission to clear land (for the plantation), gaining considerable timber revenues. Many plantation schemes are never planted. Fictitious oil palm plantations in East Kalimantan may have already cost the state more than Rp 3.5 trillion (US\$372 million) (Kompas, an Indonesianlanguage newspaper, as quoted in Sheil and Basuki, 2005). In short, plantation schemes provide camouflage for removing timber, and there has been little local publicity warning against this.

We emphasise that we are not against plantations per se; when well planned and implemented such schemes can bring benefits, but such schemes need to be based on adequate assessments, consultations and guarantees. We have already taken some steps to inform people of our results and warn against hasty and illinformed decisions (Basuki and Sheil, 2005; Sheil and Basuki, 2005). Given vested interests, this remains a difficult topic, but additional public education is needed.

Why are Malinau's forests threatened? We can dismiss two simplistic explanations: it is neither because local people don't care nor because the local government is unaware of local concerns. However, we do note scope for improvement. Of course problems remain. Agreement on a need for conservation does not imply agreement on how and where this should be implemented. Some topics not included in our survey will pose challenges; for example, road building is generally popular, but causes significant damage in the rugged interior of the district.

More importantly, at least in the short term, the switch from centralised to local government has brought considerable confusion and has not yet resulted in the consultative and responsive planning, implementation and governance that was intended. Governmental goals and processes show inertia, and working modes lag behind realities. Experience elsewhere shows that even democratic governments are slow to relinquish control over valuable resources (Edmunds and Wollenberg, 2003). Conflicts between central and local government also hinder progress. There is little in the way of on-the-ground presence or law enforcement in the more remote regions, and little clarity over how this situation might be improved. One general consequence is disorder and conflict over natural resource ownership and regulation. Insecurity has led to an ongoing 'tragedy of the commons': many who can, take advantage of the situation, and those who choose not to, lose out. Put simply, the choice is 'get something from the forest now, or lose the forest anyway and have nothing'. But some optimism is warranted. This study, and our wider consultations and informal discussions, suggest that local people want regulation as part of a fair, transparent and legitimate process.

Regional autonomy is new in Indonesia and democratic processes are young. Decisionmakers may become more sympathetic to conservation if it proves popular. Indonesia appears increasingly receptive to environmental concerns. There is an emerging pride in the nation's vast biological wealth and a growing commercial interest in green markets, such as timber certification.

Our broader vision for this project is that momentum towards environmental damage can be reduced. Balancing local needs and priorities with local realities, social and biophysical, suggests a genuine potential to build a strong local economy within a landscape that continues to maintain considerable forest cover and conservation significance. The region needs economic development, and land-use choices will need to strike an acceptable balance of costs and benefits. 
The optimal role for researchers in bringing about positive change is debatable. But in our view it is clear that the decisions to be made will be made by others: local people and their democratic representatives. Our role is to provide information and stimulate discussion. Democratic processes are still underdeveloped: people are not used to challenging orthodoxies, asking for explanations, and lobbying; and decision-makers are not used to being accountable. We do not push for specific outcomes, but promote the need for broad-based well-informed choices.

The fact that people are willing to support conservation provides a platform to develop tangible conservation benefits. As researchers, we can encourage and be engaged in this process but we should not control it. Will our efforts lead to real benefits? They might -but there is still some way to go. We note considerable local support for improved land-use planning and implementation, including conservation. This support remains largely untapped. Since our original project was undertaken and the posters distributed, the District of Malinau has made a public commitment to being a 'Conservation District' (July 2005). Though a political symbol rather than a commitment to any specific course of action, this is a positive gesture. We believe our activities, and those of other CIFOR researchers and partners, have helped.

\section{CONCLUSIONS}

Conservation planning without adequate local consultation alienates local stakeholders, and many conservation interventions are seen as just one more attempt by outsiders to gain control over land and natural resources. At best, this fails to develop a local constituency for conservation; at worst, it sparks conflict. Our studies in Malinau and elsewhere illustrate the value of creating a shared understanding of what is important as a foundation for dialogue between scientists, policy-makers and forest communities. Surveys that integrate biodiversity inventories with information on how people view and value their natural environment can help improve forest-conservation planning, address the needs of local people, and advance the management of tropical forest lands. Conservation can be undertaken by recognising and building on what local people find important.

\section{REFERENCES}

Alvard, M. 1995. 'Intraspecific prey choice by Amazonian hunters.' Curr. Anthropol. 36, (5), pp. 789-818.

Basuki, I. and Sheil, D. 2005. Local perspectives of forest landscapes: a preliminary evaluation of land and soils, and their importance in Malinau, East Kalimantan, Indonesia. CIFOR, Bogor, Indonesia.

Brandon, K., Redford, K.H. and Anderson, S.E. (eds.). 1998. Parks in peril: People, politics and protected areas. Island Press, Washington, D.C., USA.

Chambers, R., Pacey, A. and Thrupp, L.A. (eds.). 1989. Farmer first: farmer innovation and agricultural research. Intermediate Technology Publications, London, UK.

Colfer, C.J.P. and Resosudarmo, I.A.P. 2002. Which way forward? People, forests and policymaking in Indonesia. Resources for the Future, Washington, D.C., USA.

Curran, L.M. andWebb, C.O.2000. 'Experimental tests of the spatiotemporal scale of seed predation in mast-fruiting Dipterocarpaceae.' Ecol. Monogr. 70, (1), pp. 129-48.

Dove, M.R. 1983. 'Theories of swidden agriculture and the political economy of ignorance.' Agrofor. Syst. 1, pp. 85-99.

Dove, M.R. (ed.). 1988. The real and imagined role of culture in development: Case studies from Indonesia. University of Hawaii Press, Honolulu, HI, USA.

Edmunds, D. and Wollenberg, E. 2003. Local forest management: the impacts of devolution policies. Earthscan Publications, London, UK.

Ghimire, K.B. and Pimbert, M.P. (eds.). 1997. Social change and conservation: Environmental politics and impacts of national parks and protected areas. Earthscan Publications. London, UK.

Hobart, M. 1993. An anthropological critique of development. Routledge, London, UK.

Hutton, J.M. and Leader-Williams, N. 2003. 'Sustainable use and incentive driven conservation: realigning human and conservation interests.' Oryx 37, (2), pp. 215-26.

Kramer, R.C., Van Schaik, C. and Johnson, J. (eds.). 1997. Last Stand: Protected areas and the defence of tropical biodiversity. Oxford University Press, Oxford, UK. 
Krishnamani, R. and Mahaney, W.C. 2000. 'Geophagy among primates: adaptive significance and ecological consequences.' Anim. Behav. 59, pp. 899-915.

Lutz, E. and Caldecott, J. (eds.). 1996. Decentralisation and biodiversity conservation. A World Bank Symposium. The World Bank, Washington, D.C., USA.

Mittermeier, R.A., Mittermeier, C.G., Brooks, T.M., Pilgrim, J.D., Konstant, W.R., da Fonseca, G.A.B. and Kormos, C. 2003. 'Wilderness and biodiversity conservation.' Proc. Natl. Acad. Sci. USA 100, (18), pp. 10309-13.

Oates, J. 1999. Myth and reality in the rain forest: How conservation strategies are failing in West Africa. University of California Press, Berkeley, CA, USA.

Padmanaba, M., and Sheil, D. 2007. 'Finding and promoting a local conservation consensus in a globally important tropical forest landscape.' Biodiversity and Conservation. 16: pp. 137-51.

Posey, D.A. (ed.). 2000. Cultural and spiritual values of biodiversity: A complementary contribution to the global biodiversity assessment. IntermediateTechnology Publications, London, UK: on behalf of United Nations Environment Program, Nairobi, Kenya.

Puri, R.K. 1992. Mammals and hunting on the Lurah River: Recommendations for management of faunal resources in the Cagar Alam Kayan Mentarang. Kayan Mentarang. Project Report. World Wide Fund for NatureIndonesia Programme, Jakarta, Indonesia.

Puri, R.K. 1997a. Hunting knowledge of the Penan Benalui of East Kalimantan, Indonesia. PhD thesis, University of Hawaii, Honolulu, $\mathrm{HI}$, USA.

Puri, R.K. 1997b. 'Penan Benalui knowledge and use of treepalms.' In: Sørensen, K.W. and Morris, B. (eds.). People and plants of Kayan Mentarang. World Wide Fund for NatureIndonesia Programme/UNESCO, London, pp. 194-226.

Redford, K. 1991. 'The ecologically noble savage.' Orion 9, pp. 24-9.

Redford, K. and Stearman, A. 1993. 'Forestdwelling native Amazonians and the conservation of biodiversity: interests in common or in collision?' Conserv. Biol. 7, pp. 248-55.
Scott, J.C. 1998. Seeing like a state. The Yale ISPS series. Yale University Press, New Haven, CT, USA.

Shanley, P. and Gaia, G.R. 2002. 'Equitable ecology: collaborative learning for local benefit in Amazonia.' Agric. Syst. 73, pp. 83-97.

Sharpe, B. 1998. "First the forest": Conservation, "community" and "participation" in southwest Cameroon.' Africa 68, (1), pp. 25-45.

Sheil, D. and Basuki, I. 2005. Editorial: Future rides on land use. Jakarta Post, 30 March.

Sheil, D. and Lawrence, A. 2004. 'Tropical biologists, local people and conservation: new opportunities for collaboration.' Trends Ecol. Evol. 19, pp. 634-8.

Sheil, D. and Liswanti, N. 2006. 'Scoring the importance of tropical forest landscapes with local people: patterns and insights.' Environmental Management, 38: pp. 12636.

Sheil, D., Puri, R.K., Basuki, I., van Heist, I.M., Wan, M., Liswanti, N., Rukmiyati and Sardjono, M.A. 2003. Exploring biological diversity, environment and local people's perspectives in forest landscapes. CIFOR, Bogor, Indonesia. (http://www.cifor.cgiar. org/ publications/pdf_files/Books/exploring_ bio.pdf)

Sheil, D. and Wunder. S. 2002. 'The value of tropical forest to local communities: complications, caveats, and cautions.' Conserv. Ecol. 6, (2), 9. (http://www. consecol.org/ vol6/iss2/art9)

Sheil, D., Puri, R.K., Basuki, I.,. van Heist, I.M., Wan, M., Liswanti, N., Rukmiyati, Rachmatika, I. and Samsoedin, I. 2006. 'Recognizing local people's priorities for tropical forest biodiversity.' Ambio 35(1): pp. 17-24.

Sist, P., Fimbel, R., Sheil, D., Nasi, R. and Chevallier, M.-H. 2003. 'Towards sustainable management of mixed dipterocarp forests of Southeast Asia: moving beyond minimum diameter cutting limits.' Environ. Conserv. 30, pp. 364-74.

Sulastri, I. Rachmatika and Hartoto, D.I. 1985. 'Pola makan dan reproduksi ikan Tor spp. sebagai dasar budidayanya.' Berita Biol. 3, pp. 84-90. 
Terborgh, J. 1999. Requiem for Nature. Island Press/Shearwater Books, Washington, D.C., USA.

Terborgh, J., Van Schaik, C., Davenport, L. and Rao, M. 2002. Making parks work: strategies for preserving tropical nature. Island Press, Washington, D.C., USA.

Uphoff, N. and Langholz, J. 1998. 'Incentives for avoiding the tragedy of the commons.' Environ. Conserv. 25, (3), pp. 251-61.
Warren, M.D., Slikkerveer, L.J. and Brokensha, D. (eds.). 1995. The cultural dimension of development. Intermediate Technology Publications, London, UK.

Wilhusen, P.R., Brechin, S.R., Fortwangler, C.L. and West, P.C. 2002. 'Reinventing a square wheel: critique of a resurgent "Protection Paradigm" in International Biodiversity Conservation.' Soc. Nat. Resour. 15, pp. 17-40. 



\section{CHAPTER 4}

WILL FORESTS REMAIN IN THE FACE OF OIL PALM EXPANSION? A SIMULATION MODEL FOR MALINAU, INDONESIA

Aritta Suwarno, Marieke Sandker and Bruce M. Campbell 


\section{INTRODUCTION}

Environmentalists worldwide are concerned about the conversion of Indonesian rainforests to oil palm. Between 1980 and 2000 global palm-oil production increased by $360 \%$ to 20.9 million tonnes in 2000 (Koh and Wilcove, 2007) and it is forecast that global demand will double in the next 20 to 30 years (Sargeant, 2001; Reinhardt et al., 2007).

Mittermeier and Bowles (1993) consider the forests in Kalimantan to be one of the world's 15 tropical rainforest hotspots. Malinau is one of the newly designated districts in East Kalimantan Province, Indonesia (see Gunarso, this volume). Over $95 \%$ of the 4.3 million hectare area is still covered with forest (BPS Malinau, 2006). The local authorities recognise the value of the forest yet at the same time they have welcomed palmoil investments.

In June 2005, the Indonesian minister of agriculture revealed a government proposal for the world's largest oil-palm plantation of 1.8 million ha along the Malaysia/Kalimantan border, cutting through three national parks. Campaigns and lobbying by civil society, Indonesian media and foreign diplomats forced the Indonesian government to revise its position on the mega-project but, while the Indonesian President acknowledges that conservation concerns should be considered, he continues to support oil-palm development (Wakker, 2006). This is understandable when considering palm oil in the Indonesian economy. In 2004, the export value of palm oil in Indonesia comprised US\$4.1 billion or $1.7 \%$ of the Indonesian gross national income (Koh and Wilcove, 2007), and roughly 4.5 million people rely on palm-oil estates: 900,000 people through direct incomes and another 3.6 million through down-stream processing, service industries and remittances (Sargeant, 2001). Susila (2004) found oil-palm activities contribute 5-11 million Rp per annum or over $63 \%$ of smallholder household incomes in Kampar (Riau) and Musi Banyuasin (south Sumatra) and the small proportion of poor people ${ }^{1}$ $(<10 \%)$ in oil-palm communities in these sites is

${ }^{1}$ Where the poorest smallholders are those whose income is less than or equal to Rp 10 million per annum (Susila, 2004). an indication of the commodities' contribution to poverty alleviation. Conservationists face big challenges given the monetary benefits of oil palm.

For Malinau we examine the scenario of clearing 500,000 ha of forest for oil palm and its consequences for local livelihood income, district revenues and land cover change. Given the possible employment created by such development, we also examine potential migration into Malinau. The aim of this chapter is to simulate landscape dynamics in order to understand conservation and development trade-offs from the perspectives of different stakeholders. We hypothesise that conversion of forest to plantations is to the benefit of many stakeholders, especially those having the power to drive this conversion process.

\section{METHODS}

Simulation models and participatory modelling can be useful in stimulating discussion about the future, and can contribute to decisions about complex landscapes (Sayer and Campbell, et al., 2004). Sayer and Campbell (2004) argue for the use of exploratory (as opposed to predictive) models, with model building and outcomes providing a starting point for discussion amongst different stakeholders who have different perspectives on the trade-offs between conservation and development.

Initially, the idea for a model was shared with CIFOR researchers and a scoping model was produced that simulated land-cover change (Sayer and Campbell, 2004; Lynam et al., 2003). The scoping model was built using the dynamic, user-friendly modelling software STELLA v.8 (High Performance Systems, 1996). The results of the early simulations were discussed with researchers and staff of the district, including the district head (Bupati). This gave the modellers feedback on priority issues, and the model was further developed. A workshop was convened with twelve persons from the district agencies where available information and data were shared and discussed. In 2007 the scenario results were shared with district officials and the district head. The model supported policy changes on land 
use in Malinau, tempered local government's enthusiasm for oil palm and spurred their interest in payment for environmental services schemes (Dwi, pers. com. 2007). More information on the modelling procedure can be found on: http://www.cifor.cgiar.org/conservation/_ref/ home/index.htm. We stress that the model is not meant as a predictive tool - it's primary use is to promote dialogue about alternative trajectories of change.

The model includes variables covering land use, human populations, employment, forest and plantation economics, and district income. To identify the current status of livelihoods in Malinau District, we used data from the district statistical office (Badan Pusat Statistik, BPS) and data from CIFOR researchers working in Malinau between 2000 and 2007. All monetary values are reported in Indonesian Rupiah (Rp), where US\$1 = Rp 9,500. The sensitivity of the model's response to some key variables (income from agriculture, oil palm and timber salaries, and immigration rate for jobs) has been tested by changing their values $+/-20 \%$.

\section{LAND USE, LAND-USE SCENARIOS AND LAND-COVER CHANGE}

\section{Main land use and forest types}

With decentralisation in 1999, land-useallocation has come increasingly under the control of the district government, though allocation in the forestry service area is still legally under central government (see Wollenberg et al., this volume). Conservation and protection forest form a large part of Malinau, dominated by Kayan Mentarang National Park (Table 1).

For the model, we have divided forests into primary forest, primary logged-over forest and secondary forest (Figure 1). Secondary forest is bush fallow after abandoned swidden cultivation and very intensively logged forest (with largeand small-scale conversion permits - IPK and IPPK, respectively). Based on documentation in the district offices and estimation of land under swidden cultivation over the period 1967-2002, the secondary forest extend is $\sim 120,000$ ha. Roughly $20 \%$ of the landscape was logged by 2004.

\section{Logging and Conversion Permits}

With decentralisation, district officials have gained greater control over forest resources, often extending well beyond their official legal authority. They started issuing logging permits for small concessions (IPPK) in areas supposedly classified as conversion forest (Obidzinski and Barr, 2003). There was minimal regulation of the subsequent logging. Barr et al. (2001:13) report on the enthusiasm of a palm-oil company manager about the decentralisation process stating '...operations will be much smoother and more efficient if companies can deal straight with the Bupati'.

Table 1. Land-use allocation for Malinau 2006

\begin{tabular}{ll}
\hline Land-use allocation $\mathbf{2 0 0 6}$ & Area (hectares) \\
\hline Total Area Malinau District & $4,262,070$ \\
\hline Non-forestry service land & 518,927 \\
\hline Of which: & 19,919 \\
\hline Mining concession (2002) & 18,947 \\
\hline Currently under agricultural use (paddy, crops, vegetables, fruits and estate crops) & $3,743,143$ \\
\hline Forestry service land & 225,828 \\
\hline Of which: & 453,653 \\
\hline Conversion forest & $1,280,836$ \\
\hline Production forest & $1,782,825$ \\
\hline Limited production forest (on steep slopes) & \\
\hline Protection forest (national park and forest reserves) &
\end{tabular}

Source: Dinas Kehutanan dan Perkebunan Kab. Malinau, 2006; TGHK revised 2002 for mining area 


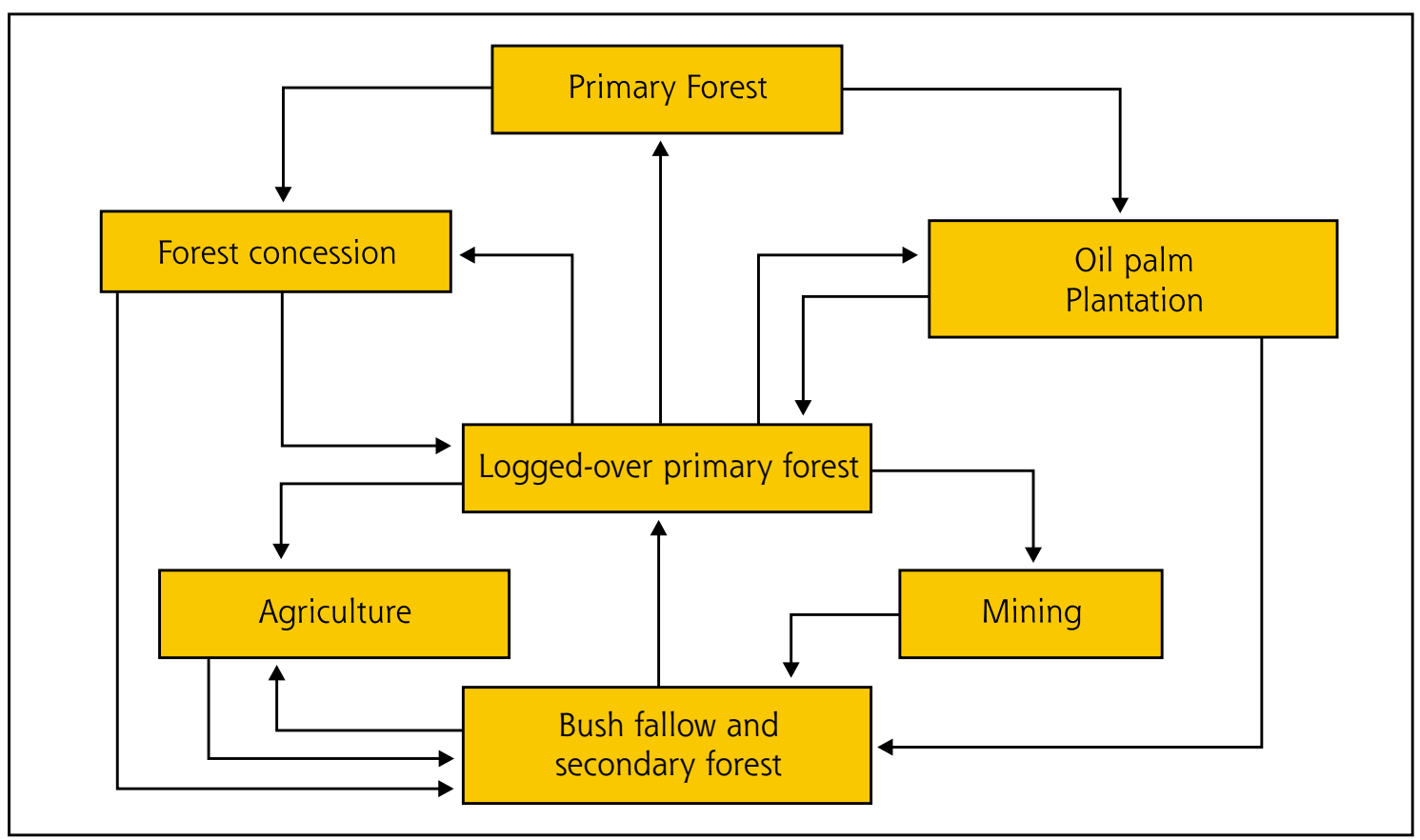

Figure 1. Major land-use sectors captured in the model, showing the potential land-use transformations

A frequent practice observed in Indonesia is that IPK concession holders (those holding permits for large-scale forest conversion) do indeed extract timber but have no intention of converting the area into plantations. Of 2.5 million ha cleared for oil palm in East and West Kalimantan, only $20 \%$ had been planted up to 2005 (Wakker, 2006) with the remaining area thought to be cleared mainly for its timber. In the neighbouring district of Berau, the governor is under prosecution for 'abuse of power' through the issuance between 1999 and 2002 of permits for the development of a million hectares of oil palm (TTM report, 2006). The company that received the permit cleared the land, made use of the wood but never planted oil palm. In Malinau there have also been major proposals for oil palm where land is regarded as unsuitable for oil palm, being remote, very steep and with infertile soils (Basuki and Sheil, 2005; Lynam et al., 2006), leading to the belief that the proposed conversion of land for oil-palm development is a guise for timber harvesting. Neighboring districts closer to the sea with extended lowlands would be more cost-effective investments for oil palm in the short term. However, the road network is rapidly expanding with new roads now linking Malinau to Nunukan and Bulungan district, so markets are effectively becoming more accessible and oil-palm investments more likely to happen.

\section{Oil-palm scenarios}

Currently there are no plantations in Malinau. In our simulation we assume the installation of oil palm to start in 5 years' time (2012). To explore the potential future impact of oil-palm development, we have used four scenarios:

- I No oil-palm development (as at present);

- II Forest clearing, but no oil palm planted;

- III Forest clearing and oil-palm plantation assuming (a) low employment rates and (b) high employment rates.

In scenario II and III, five logging permits for forest conversion are issued for an area of 100,000 ha each. Permits for plantation production are usually given for a 25-30-year period and after that can be extended or terminated. The timber clearing through IPK permits in scenario II and III is assumed to take place over a period of 20 years (from 2012-2032 in the simulation), increasing in intensity over time (too few workers and equipment are available in the first years). Thus after 25 years 500,000 ha of forest will be cleared.

Under scenarioll we simulate 'timber speculators' who intensely log primary logged-over forest labelled as conversion forest, converting it into secondary forest, with some logging of the 


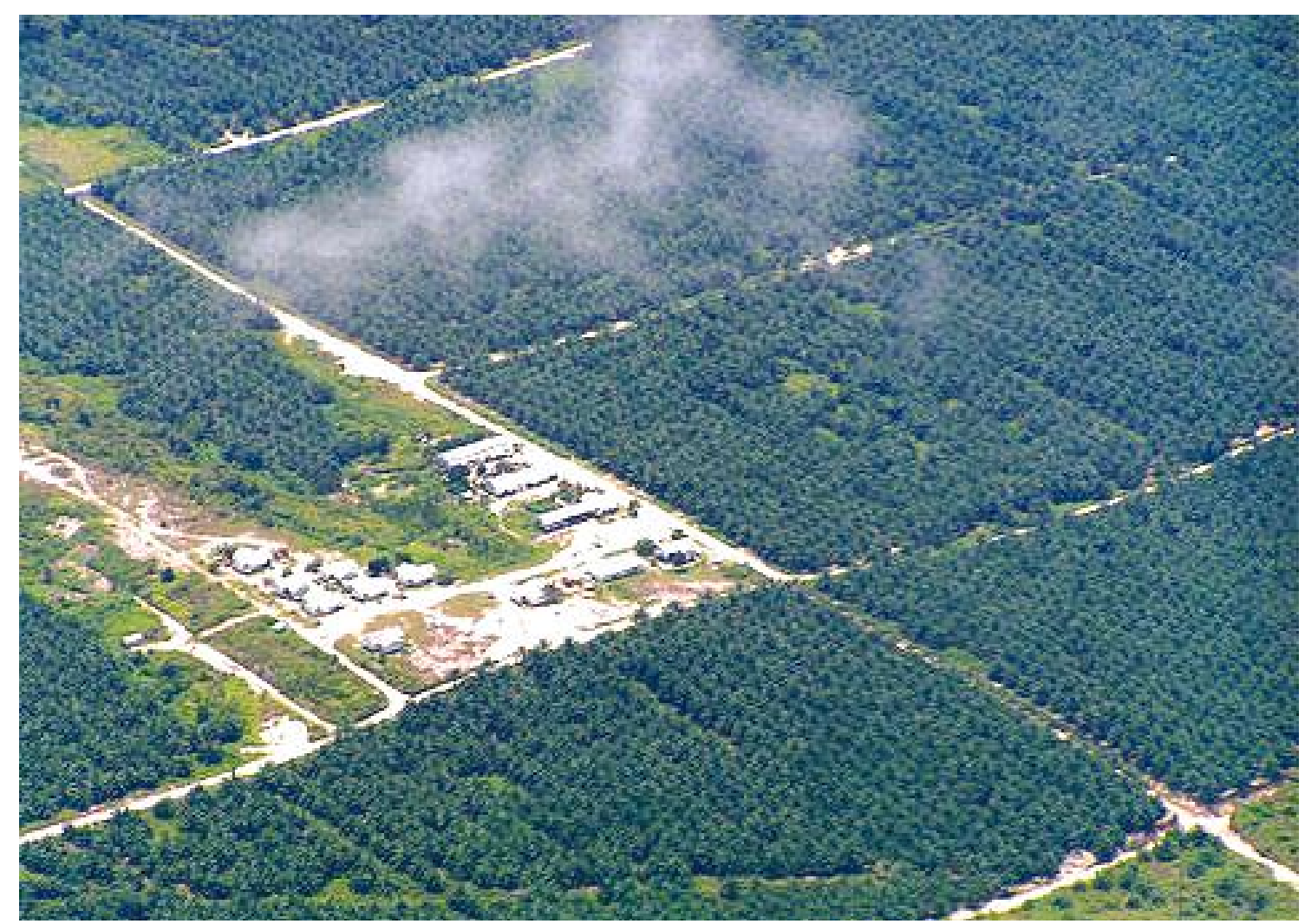

Oil palm development in Malinau (Photo by Douglas Sheil)

permanent forest estate. Some of the forest logged will be located on steeper slopes. Furthermore, we assume that the company gives logging jobs to migrants only and only pays a minimum compensation fee of $\mathrm{Rp} 5,000 / \mathrm{m}^{3}$ to villages.

In scenario III (a) and (b), we simulate more responsible companies planting the full 500,000 ha, $40 \%$ from secondary forest and $60 \%$ from primary logged-over forest, all of which is conversion forest. We assume the plantations are largely located in lowlands closer to transport routes (e.g close to Malinau town). Scenario III (a) assumes an employment of 0.1 jobs per ha of oil palm, which corresponds with current employment figures in Malaysian oil-palm plantations (van Noordwijk, pers. com. 2007). Scenario III (b) assumes an average of 0.2 jobs per ha of oil palm corresponding with Indonesian contexts (Sargeant, 2001). It is assumed villages get a fee of $20,000 \mathrm{Rp} / \mathrm{m}^{3}$.

The timber compensation fees of $\mathrm{Rp}$ $5,000-20,000 / \mathrm{m}^{3}$ are a low to moderate estimate as Palmer (2004) mentions the fees can go up to
$50,000 \mathrm{Rp} / \mathrm{m}^{3}$, while Barr et al. (2001) record a fee of up to $30,000 \mathrm{Rp} / \mathrm{m}^{3}$. The Rp 5,000 fee follows an example in Malinau mentioned by Barr et al. (2001: 32).

\section{Agriculture}

For many years, livelihoods in Malinau District have been dominated by agriculture and huntinggathering (Levang et al., this volume). Of the local population, about $75 \%$ live outside the district capital, with the majority being swidden cultivators. A few are hunter-gatherers but even $80-85 \%$ of these Punan households undertake farming, and in remote areas this percentage is even higher (Levang et al., 2005). Despite the prevalence of agriculture, its formal contribution to the district's economy was only $6 \%$ in 2002 (BPS, 2003 in Andrianto, 2006). The population sub-model drives the rate of increase or decrease in farming households, and this feeds directly to the area farmed. A slight shift from jobs in agriculture to jobs in the service and trade industry is modelled as a result of urbanisation. 

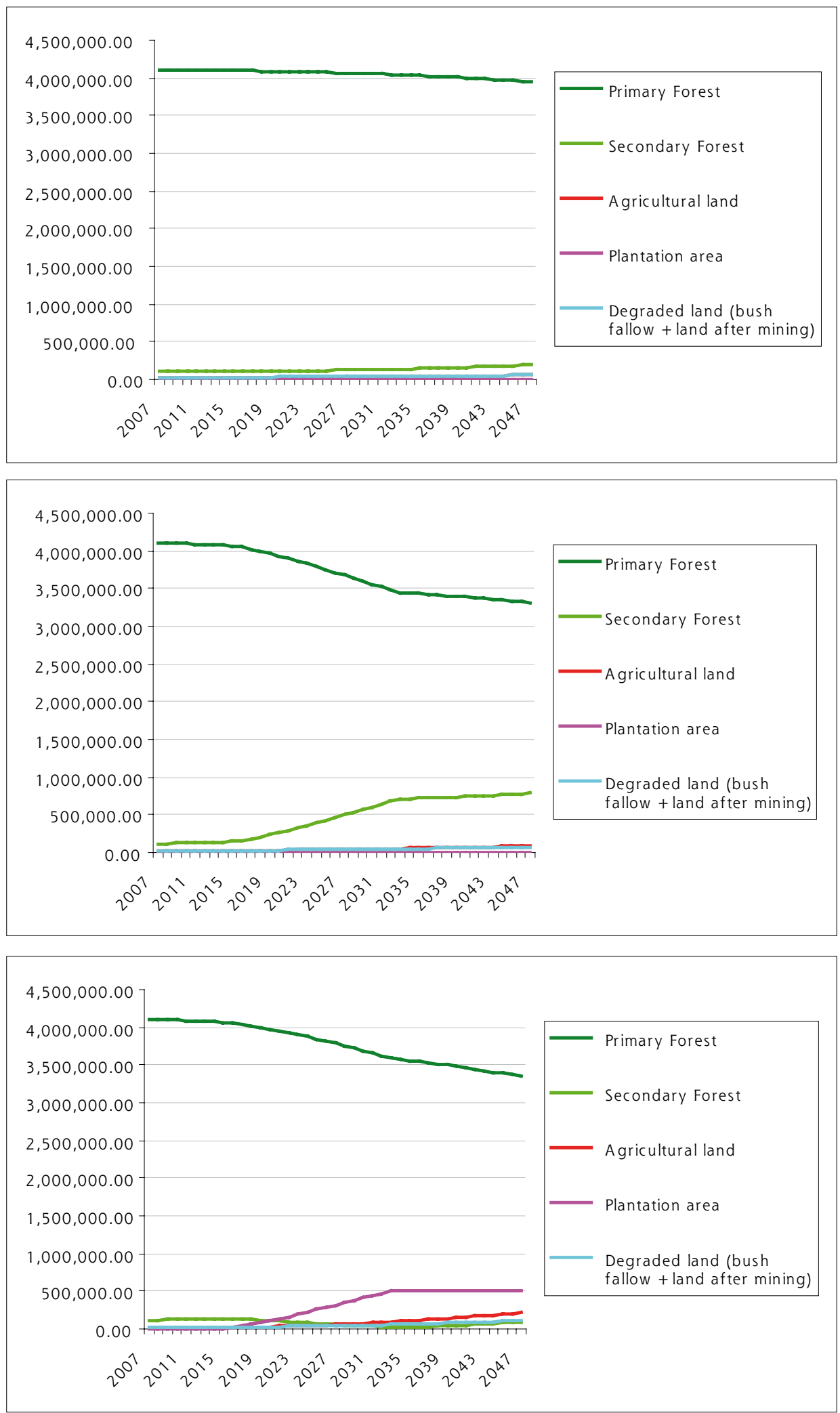

Figure 2. A 40-year simulation of land cover in Malinau district: (a) No plantation development; (b) Forest clearing without oil palm planted; (c) Plantation development (high employment) (y axis representing Indonesian Rupiah) 
We distinguish between permanent and swidden cultivation. The former is intensive crop and tree production. Swidden cultivation is prevalent. It starts with the conversion of logged-over primary forest to dryland rice cultivation. After about 2 years, when crop yields are low and weed infestation increases, farmers abandon the field and it becomes bush fallow. At the moment, the pressure on land is so low that bush fallow is left to grow into secondary forest which is only again converted into swidden fields when it is very old and resembles primary forest again. However, under the oil-palm scenario, primary forest and old secondary forest in the villages' vicinity will become scarce and thus the farmers will be forced to reduce the fallow period which will result in lower per hectare swidden yields (modelled to drop by 30\%) and higher levels of weed infestation. This could lead to increased application of herbicides.

\section{Mining}

A small area of the landscape is allocated to coal mining (Table 1), but of that only about $30 \%$ of this has been actually worked. Recently, mining activities have ceased altogether. It is difficult to predict future mining activities, but with high transport costs in Malinau we have assumed only a small annual increase in area mined (from 1,000 to about 2,000 ha/year under scenario III b). This increase is due to the population increase, where a proportion of the unemployed commence artisanal mining.

\section{Forest Products}

People in Malinau depend heavily on forest products for their livelihoods (Levang et al., this volume). Levang et al. (2005) found that $72 \%$ of the local Punan people collect forest products but only for $16 \%$ was it the main cash income. Their study shows that the mean annual income of a Punan household from agriculture is $\operatorname{Rp~1.67-2.25~million~while~that~}$ from forest products is Rp 1.72-4.56 million, depending on the relative accessibility of villages. These figures apply better to the more remote hunter-gatherer communities. According to Pambudhi et al. (2004) oil-palm and pulp plantations often displace villagers and their rattan gardens. An increase in IPK logging and plantations is assumed, in the model, to result in decreased availability of non-timber forest products (NTFPs). We assume in the model that about $70 \%$ of local people are involved in forest product collection but that only $10 \%$ of migrants collect forest products.

\section{Simulated land cover changes}

Under the no plantation development scenario we assume that the current secondary forest $(\sim 120,000$ ha) can grow into primary forest during the simulation, while under the other scenarios we assume no such land-cover change because of the high pressure on forest. Without plantation development, there is a loss of only $\sim 5 \%$ of primary forest over 40 years, largely a result of on-going timber concessions (HPH/ IUPHHK permits) (Figure 2). The simulations where forest conversion permits are issued (II and III) suggest a loss of about $20 \%$ of primary forest over 40 years. The assumption here is that IPK logging takes place from year 5-25 of these simulations, while HPH/IUPHHK logging occurs throughout.

Agriculture comprises a very small component of land use in Malinau, initially due to the low population numbers and the low commercial demand for agricultural products. With the forest clearance scenarios, agricultural area increases 4.5 to 11 times (scenario II and IIIb, respectively), due to expanding populations (see next section). Degraded forest (bush fallow and land after mining) is around 16,000 ha in year one but this expands to about 58,000, 74,000, 91,000 and 109,000 ha in scenarios I, II, IIIa and $b$ respectively, mainly as a result of the increase in bush fallow.

Fire is not included in the model, and has not been a feature of Malinau. However, the amount of forest lost could be underestimated in the oilpalm scenario as fire is a significant threat in other parts of Indonesia, and forest concessions and those establishing tree-crop plantations are considered major contributors to fire frequency (FAO, 2003; Gönner, 2000). Once fire enters into the system, it may remain as a permanent feature (du Toit et al., 2004). The Department of Forestry and Plantations (1998, in Casson 2000) holds oil-palm expansion partly responsible for the 1997-8 forest and land fires that affected more than 5 million ha of forest in Kalimantan. 


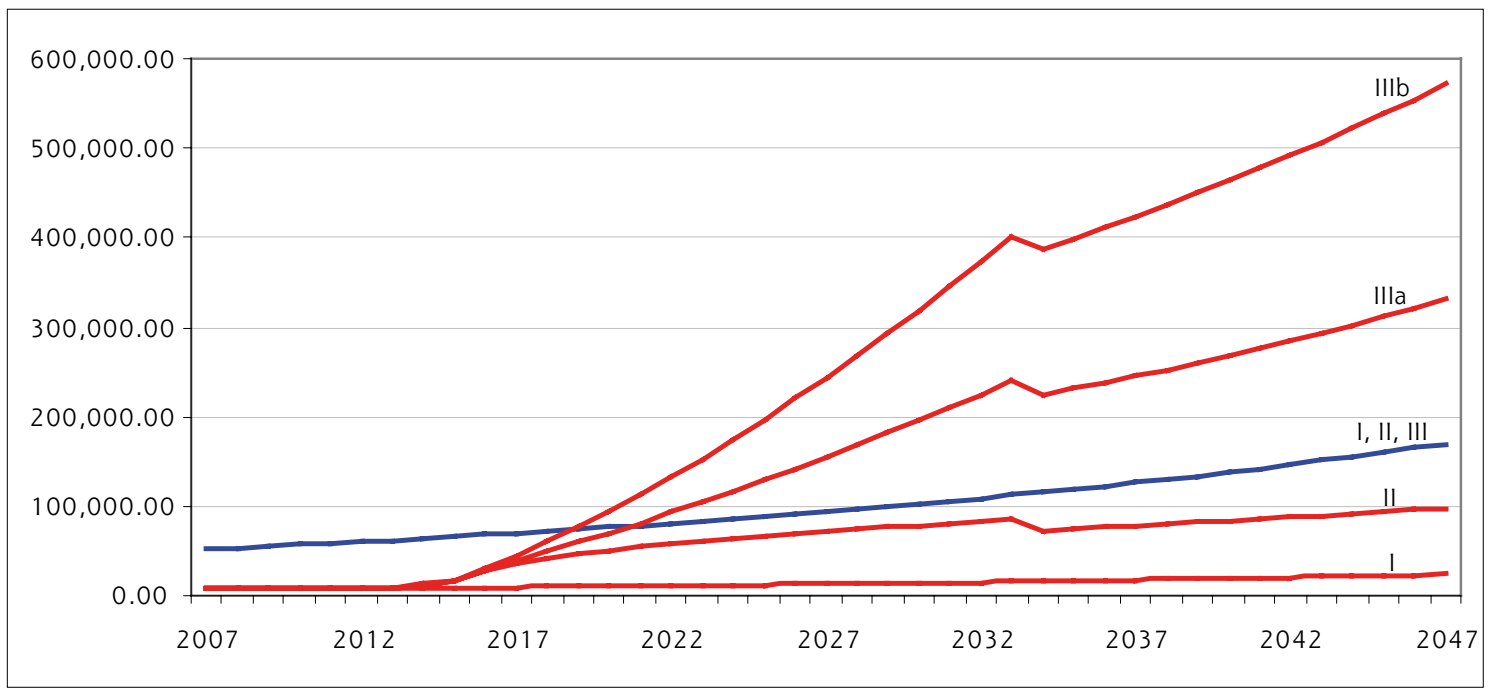

Figure 3. A 40-year simulation of total local population (blue lines) and migrant population (red lines) in Malinau District, under the four different scenarios (I= no plantation; II = IPK clearing without plantation development; $\mathrm{III}=$ plantation development assuming (a) low employment and (b) high employment)

\section{ECONOMIC DEVELOPMENT}

\section{Population numbers}

The total population in Malinau District was 59,212 in 2006 (BPS Malinau, 2006) and has increased by $6.5 \%$ p.a. over the last 8 years (Bappeda Tk II Bulungan, 1998; BPS Malinau, 2006). This high annual increase rate is mainly due to in-migration related to new economic opportunities. The average increase in the urban Malinau sub-district was 8.5-9\% compared to $3 \%$ in the rural sub-districts. The model simulates natural growth and in-migration, and differentiates between local people and transmigrants. CIFOR researchers estimate that of the 59,212 in the district about 7,000 are immigrants, most living in Malinau town and some in Long Loreh where the mining company was previously active. In-migration in the model is largely driven by jobs in IPK logging and oil-palm plantations, where we assume three people to immigrate for each new job filled by a migrant, causing the migrant population to rise sharply with the plantation development scenarios (Figure 3). The total population in Malinau under the plantation development scenario will increase by 4.7 (scenario II) to 13.5 times (scenario IIIb) after 40 years. After year 2027 of the simulation, the employment drops due to the sharp decrease in timber jobs (2027) when IPK logging stops. For the model we assume that, where migrant employment drops under 35\% (meaning less than 35\% of employable migrants are employed), this results in out-migration rates as high as $2 \%$. Under scenario IIIb, the now modest number of 7,000 migrants will increase by a factor 80 after 40 years. While local Dayak people are currently in the majority, they will be a minority if 500.000 ha is planted with oil palm.

\section{Financial Compensation from Logging Companies to Local Communities}

Decentralisation not only resulted in district governments securing a greater share of forestry revenues, but also had implications for local communities. A 2000 law entitles communities to demand compensation for timber harvesting from concession holders, though this law is open to dispute due to weak property rights (Engel et al., 2006). Andrianto (2006) records greater conflicts amongst communities and environmental degradation following the implementation of the new regulations regarding logging, and he concludes that in West-Kutai and Malinau District the policies have failed to increase the standard of living of poor communities. On the 


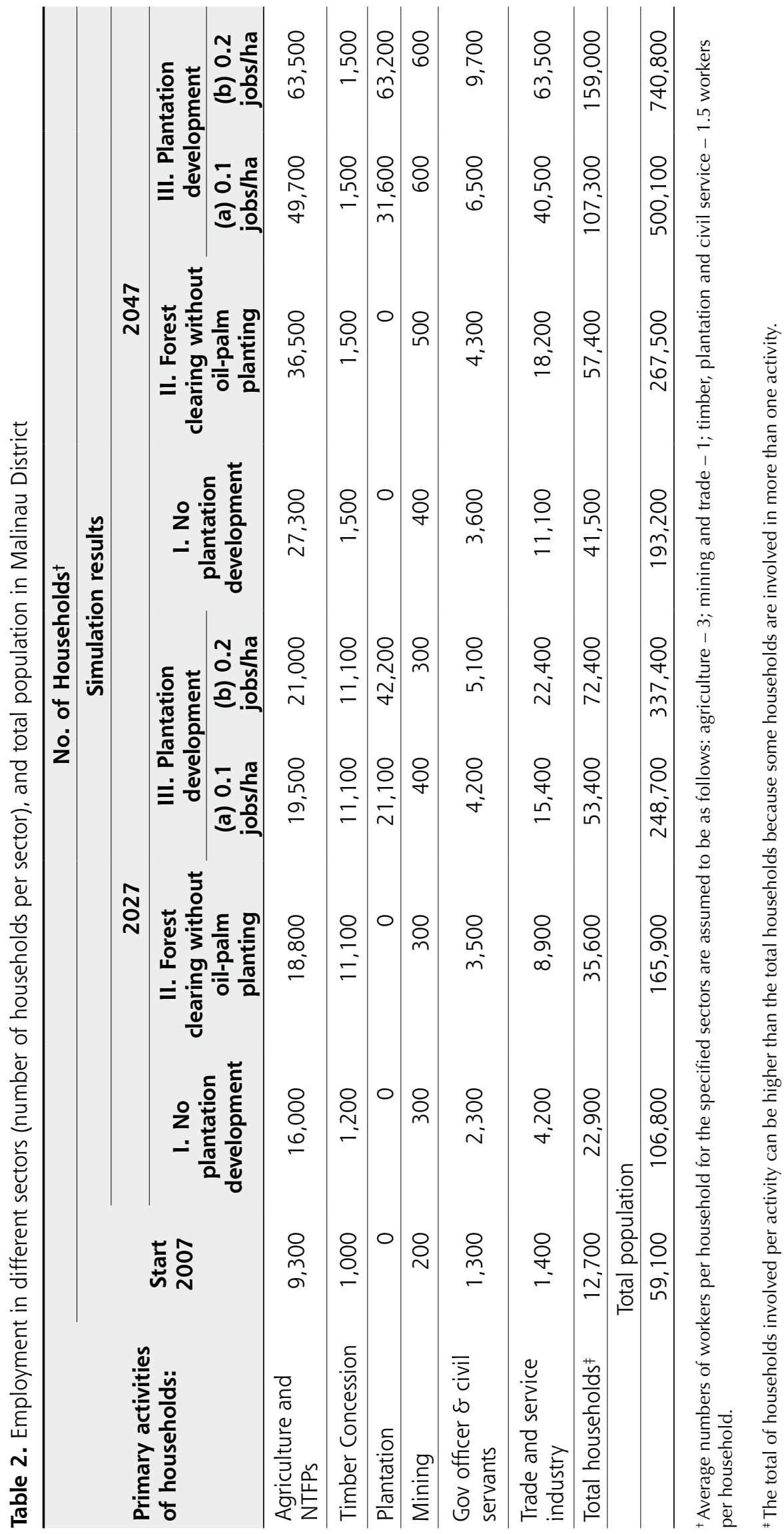




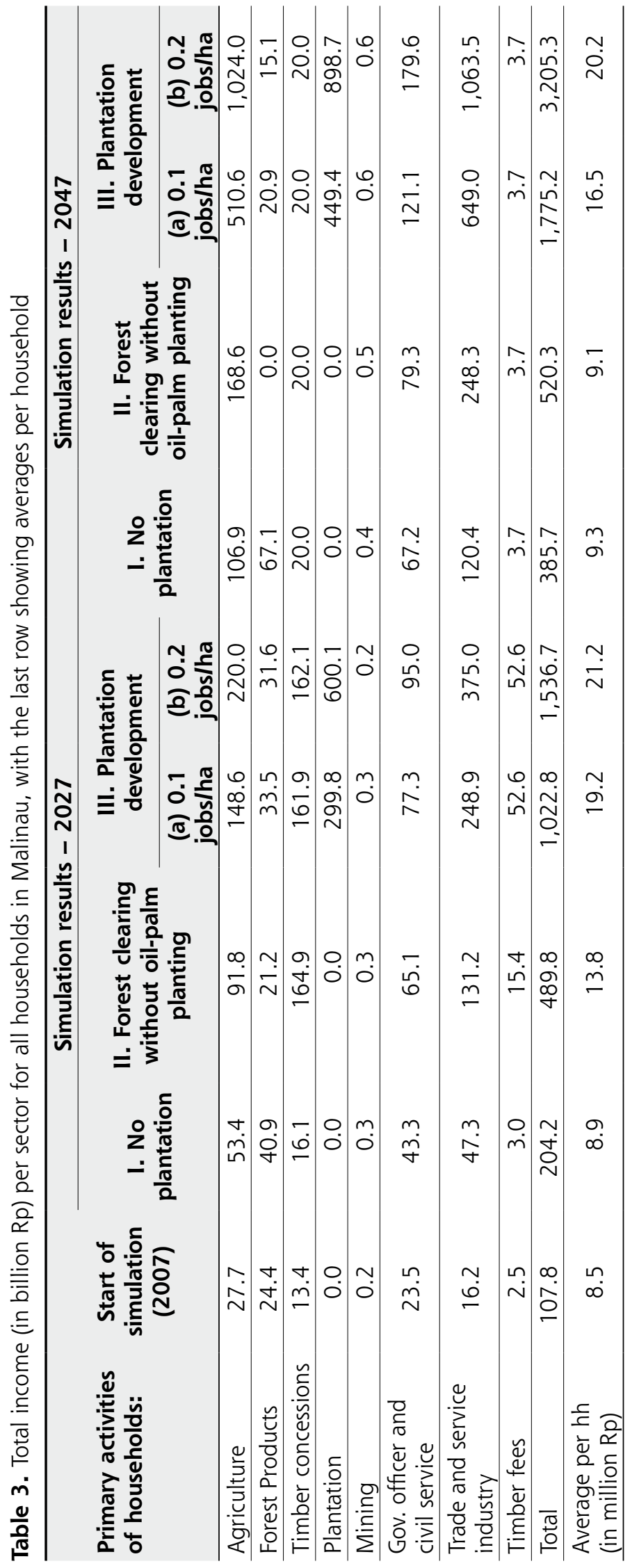




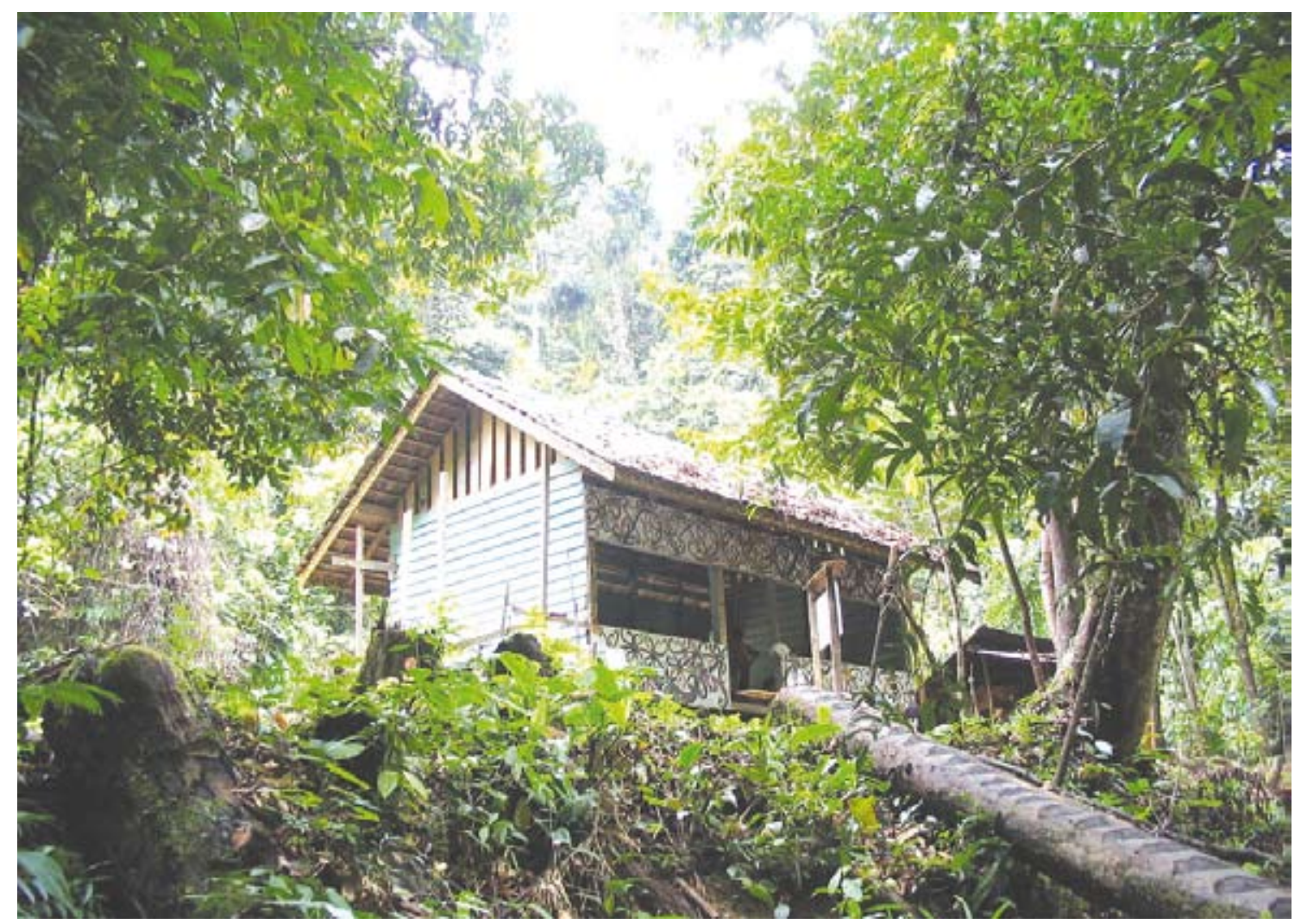

Hut for eco-tourism activities built by the Setulang community in Malinau (Photo by Bruce Campbell)

contrary, Palmer (2004) states decentralisation has undoubtedly led to higher capture of logging rents by the Sekatak community in Malinau. Palmer (2004) and Barr et al. (2001) indicate mixed outcomes from local negotiations, Barr et al. (2001: 30) noting that many agreements are 'absurd or have been unfulfilled'. Palmer (2004) mentions IPPK fees of around Rp $50,000 / \mathrm{m}^{3}$ of timber going to local communities. While this is low, it is five times more than the fees paid by the large logging companies (the companies that dominated the logging industry prior to decentralisation).

\section{Household income}

At the start of the simulation, the percentage of households is highest in the agricultural sector $(73 \%)$ (Table 2$)$. With the exception of scenario III, agriculture remains the most important sector throughout the simulations, though under scenario II and III, the number of households in the timber sector increases more than 10 times after 20 years (mainly because of IPK). In 2027, the most substantial number of households will be active in the oil-palm sector in scenario III though by 2047 this will have shifted to the agriculture and the trade and services sector because the number of jobs in the oil-palm sector does not continue to increase after 25 years while the population does. The creation of employment in the region is substantial under the oil-palm scenario, even when a low employment rate is used. With scenario I, the total number of formal jobs available (in mining, timber and civil service) does not exceed 10,000. In the other scenarios the number of formal jobs reaches as high as 22,000 (scenario II), 71,000 (scenario IIla) and 120,000 (scenario IIIb).

The significant amount of income generated by employment in oil palm in year 2027 under scenario III is shown in Table 3. There are also associated expansions in other sectors driven by the plantation economy. The income from agriculture increases substantially, for example. With an increase in employment we assume a high demand for agricultural products, and roads opening up the area improve market access. Where most of current production is 
for auto-consumption, we expect an increase in permanent agriculture and the demise (in proportionate terms) of swidden cultivation.

Levang et al. (2005) undertook household surveys sampling 254 Punan households in six different settlements in Malinau and neighbouring districts. They found $83 \%$ of the sampled households live under the US\$1/day poverty line. Average incomes per household are improved under the oil-palm scenario (III), increasing by $94-145 \%$, while increasing $<10 \%$ in scenario I without oil palm (Table 3, last row). With forest clearing without oil palm (scenario II), the amount of money in Malinau's economy is higher then under no IPK issuance (scenario I), both after 20 and 40 years. Even so, the average income per household is lower in year 2047 compared to the no plantation scenario due to the increased total population.

The above figures hide the differentiation between local and migrant households. The activity portfolio differs substantially for migrant and local households. Migrants are at the moment largely urban, with a high percentage of households active in the trade and service industry (Table 4). Jobs in the timber and plantation sector typically go to migrants who often have higher schooling levels. On the contrary, local people are currently given priority for all jobs in the civil service and they are also receiving compensation fees for logging (Table 4).

Local people have short-term benefits from scenario II (2027) with more commercialised agriculture, more civil servant jobs and timber fees. After 40 years though, they are left with hardly any forest in the proximity of their villages, reducing their income from forest products (including fish) and shortening their fallow periods in shifting cultivation, consequently lowering their yields. Migrants will have most of the short-term benefits, securing most jobs in IPK forest clearing. After 40 years the high unemployment under migrants will cause some out-migration, though most migrants are expected to remain; a proportion of whom will buy a piece of agricultural land and start farming for much lower earnings. This scenario is expected to cause high levels of conflicts. Koczberski et al. (2001) and Casson (2000) report cases of local resentment of the fact that benefits from oil-palm plantations often accrue to outsiders.

Scenario III improves incomes for both local people as well as migrants. Local people's incomes increase mainly in year 2027 when timber fees increase $>20$ times (Table 3), dropping thereafter when IPK logging ends. Incomes remain $38-75 \%$ higher than under scenario I at the end of the simulation, mostly because of the commercialisation of agriculture, although jobs in civil service, trade and the service industry also contribute to higher incomes. Migrant incomes are also highest in 2027 due to the availability of jobs in IPK logging. After the sharp decline in IPK employment, a share of migrants will be able to secure employment on the plantations and a share will buy some land for agriculture. While incomes may have increased under oilpalm development, overall well-being is more difficult to judge. Colchester et al. (2006) give examples of increased social and financial costs with oil palm arrival. For example, there were social costs of resolving conflicts over land and benefit-sharing associated with oil-palm estates. Air quality declined and there was a worrying increase in alcohol abuse in local communities. More research is needed on the negative and positive impacts on local people of oil palm plantations.

\section{District development}

Since Malinau was declared a new district in 1999, district income increased radically from only Rp 5.8 billion in 2000 (Barr et al., 2001) to $\mathrm{Rp} 405$ billion and Rp 615 billion in 2002 and 2003 respectively (Andrianto, 2006). Using per ha and per $\mathrm{m}^{3}$ payments applied to IPPK in Malinau (Barr et al., 2001), the issuance of IPK permits for the clearance of 500,000 ha forest will provide the district with Rp 703 billion extra income over 20 years. Under scenario III, an additional Rp 102 billion is provided over the 40 years' simulation by oil-palm production fees. The district income will increase more than these fees though, since the increased economic activity is expected to augment substantially tax payments in the district. The simulated additional tax payments over 40 years for scenario II, IIla and IIIb are Rp 22 billion, Rp 149 billion and Rp 276 billion respectively. 


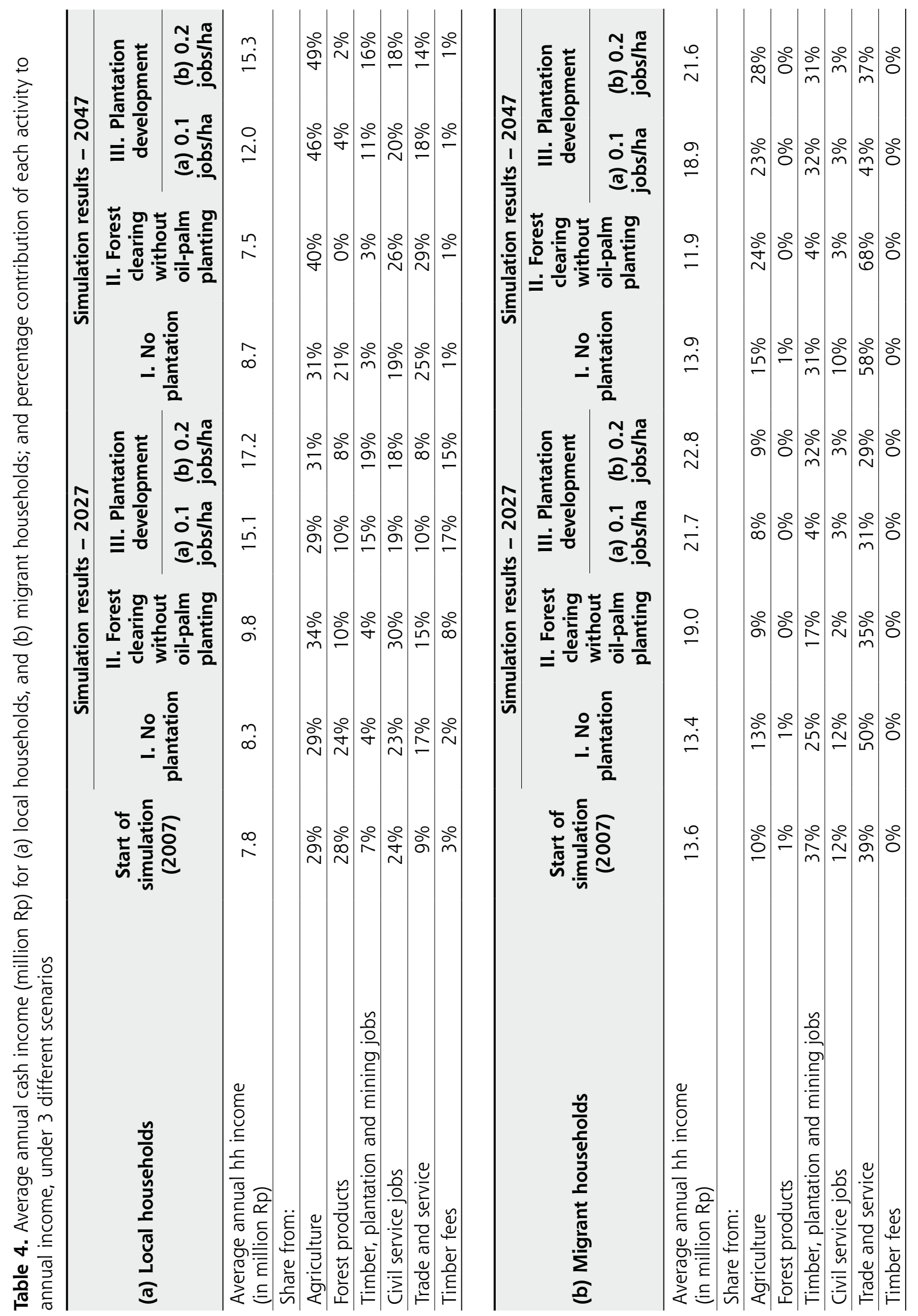




\section{DISCUSSION}

\section{Are payments for environmental services a viable economic option for the district?}

Given the economic attractiveness of the oilpalm development scenario to district and national government stakeholders, as well as to many local people, the question is whether conservationists have alternative development scenarios? Much is made of direct payments for environmental services (PES) (Ferraro and Kiss, 2002; Boedhihartono et al., 2007), and one could argue that the interest of the global community in biodiversity could change the incentive structure for local and district stakeholders by paying for biodiversity services provided by Malinau. However, the area is vast and the size of payments (needed to achieve similar household income increases as with the oil-palm scenarios) would range between US\$25-48 million/year or US\$50-96/ha/year. This is probably beyond most budgets for conservation. The difficulty of securing biodiversity payments is illustrated by Wunder et al. (2004).

Carbon PES may have the highest potential for influencing district decisions regarding forest conversion. For carbon payments to provide the district (i.e. excluding household income considerations) with the same level of district income as scenario $\mathrm{IIlb}$, an average payment per annum of Rp 27 billion/year would be needed (about US\$3 million/year). According to de Bruijn (2005), the carbon content of 1 ha of primary forest is roughly 300 tons $\mathrm{C} / \mathrm{ha}$, while the content of carbon for oil palm is $50-125$ tons $\mathrm{Cl}$ ha. A modest estimate of the amount of carbon to be saved from being emitted if the forest is not converted to oil-palm plantation is thus 175 ton $\mathrm{C} /$ ha, equivalent to 647 ton $\mathrm{CO}_{2}$ /ha (assuming it is all primary forest that is lost). For the total 500,000 ha of primary forest that would be lost in the plantation-development scenario, it would be easy to recoup the district income foregone with a carbon payment as, at US\$2/ton $\mathrm{CO}_{2}$ in excess of $\$ 15$ million/year could be generated if the payments were structured over 40 years. Karky (2006:14) mentions a 'conservative price assumption' of US\$2/ton $\mathrm{CO}_{2}$ on the Clean Development Mechanism (CDM) market. Avoided deforestation is not currently part of
CDM, so the price would probably be lower. Transaction costs on avoided deforestation would be high. For example, an elaborate monitoring system would need to be established for checking compliance, but even then it is possible that carbon could compete with oil palm for district income. This PES scenario would not lead to jobs and higher economic development in the district. PES scenarios in which some money is paid directly to communities would also need to be explored.

\section{Can eco-tourism and forest product certification provide an alternative economic pathway to oil-palm development?}

Approximate calculations indicate that Malinau would have to host $75,000-150,000$ tourists per annum to generate the household income that the oil-palm scenario produces (assumes tourists stay on average 10 days and spend US\$30/day that goes to Malinau households). Malinau has much to offer tourists with its vast intact forest and cultural diversity, but despite 19 years of lobbying by a conservation NGO, Kayan Mentarang National Park registers less than 40 tourists per year (Iskandar, pers. com., 2007). Eco-tourism will not be able to compete with oil palm, at least for the foreseeable future. Furthermore, even under the oil-palm scenario most of the district will remain forest so ecotourism development is not excluded from this scenario.

Fair-trade labels and natural-product labels for forest products can increase prices, but not to the extent that would be required if forest products were to compete with plantations as a source of income for districts and households. To compete, incomes from forest products would have to grow at least by 5-7 times. Paz Soldan and Walter (2003) give an example of certified Brazil nuts in Chile, which after certification had 1.7-2.2 times higher price.

\section{Conservation and development trade-offs}

The Malinau District illustrates the tensions that exist between conservation and development, but also illustrates how these trade-offs are 
differently perceived by the different stakeholders (Boedhihartono et al., 2007). Malinau, with its vast forests, is one of the rainforest biodiversity hotspots of the world (Mittermeier and Bowles, 1993), and conservationists are up in arms over the proposed plans for logging and conversion to oil palm (e.g. see Wakker, 2006, a study commissioned by Friends of the Earth). And yet, while the head of government in Malinau is willing to declare the district a 'conservation district' (one of only two in Indonesia), he sees no conflict between this declaration and his support for large-scale conversion to oil palm. When asked, local people are generally in favour of conservation (Padmanaba and Sheil, 2007), but they might be interested in earning some ready cash if oil-palm companies come along.

Researchers have witnessed massive change in Malinau over the last decade (Sayer and Campbell, 2004; Gunarso, this volume; Gunarso et al., this volume), and land use change is likely to be widespread and accelerating, largely driven by decisions made in the district capital and beyond. These decisions will inevitably involve logging and plantation development and perhaps mining. Allocating primary and secondary forests to plantations and other intensive land uses can be to the benefit of many stakeholders, while it can at the same time increase poverty. The behaviour of the plantation concessionaires is crucial as to whether living standards will improve or deteriorate. Very careful decisions have to be made when selecting companies for land clearing, and contracts have to be watertight so that companies deliver on promises. If companies were to plant oil palm, local people see the promise of jobs with higher cash incomes. District officials see greater economic activity, more immigrants and larger district budgets. Migrants from other more populous districts see jobs. Some of the income gets back to the national coffers and the nation's politicians and officials see development occurring, which is a major aspiration. Even with 500,000 ha of forest cleared, the major part of the district remains forested at the end of the 40-year simulation period. If this is the case, then many would argue, that plantation development scenarios are not at odds with the proposal for Malinau to be managed as a conservation district. But such development does have its risks. Firstly, we assumed logging ceases after 20 years. Secondly, we have not factored in fire; if large forest fires enter the system, as happened in 1997-8 in other parts of Kalimantan, then forest quality could be substantially compromised. Thirdly, with such a large migrant population under the oil-palm scenario, future pressures on the environment (e.g. artisanal gold panning) are likely to increase.

On economic arguments alone, part of the forest is likely to be converted in the future, though remoteness and poor-quality soils may keep plantations out of Malinau for a while. There are other social and environmental costs, not captured in the economic argument. For example, Koczberski et al. (2001) and Casson (2002) both have recorded resentment by local people towards migrants with jobs in plantations. In Malinau this could be more extreme as local people will be quickly outnumbered by migrants. Colchester et al. (2006) report local people's complaints about plantations in other parts of Kalimantan where individual profit-seeking has replaced traditions of communality and solidarity. However, Sheil et al. (2006) observes that 'decision makers prefer to focus on the general rather than the particular', so whether these negative aspects are taken into account if and when the decision on development is made remains to be seen.

If conservationists don't like the idea of large-scale land-cover change, do they have alternatives for those hungry for development? Certification of forest products and eco-tourism alone are not likely to provide incentives to halt forest conversion. Carbon payments could conceivably bring district benefits as high as those derived from logging and plantations. However, the science and politics of avoided deforestation is, as yet, poorly developed. A major question is: when will conservation options be able to start payments? Decisions about developing plantations today will not wait for the long process of international negotiation on mechanisms for carbon payments.

Discussions with the district head and his officials on the scenario outcomes centred around in-migration and carbon payments. The district officials were exceptionally nervous about the immigration rates that large-scale oil palm would stimulate, as the district is currently dominated by Dayaks (and they also 
hold positions of power); this could change with high in-migration. The district has become very interested in carbon payments as an alternative, and the district head plans a presentation at the 2007 climate-change summit in Bali, drawing on model outputs. The model filled its role as a means to stimulate discussion and helped officials in seeing some of the potential negatives of large-scale oil-palm development.

Like any model, ours makes many assumptions and simplifications. We have endeavoured to make these assumptions and simplifications as reasonable as we can based on the information available to us. Nonetheless, whether our model yields a credible representation of Malinau can be questioned by those who disagree with these choices or would emphasize unknowns or uncertainties. For example, our model cannot be taken as evidence that 500,000 of oil palm developments in Malinau will be commercially successful - field-based land suitability evaluations would need to be conducted, for example. Furthermore, a more thorough accounting of the impacts in each scenario would require environmental and social impact assessments focused on the specific areas to be planted in the light of the specific development plans proposed and the management standards applied - something that we make no claim to have done. Given the rise of interest in oil palm for biofuel, research on the social and economic impacts of oil palm is urgently required.

\section{ACKNOWLEDGEMENTS}

The authors thank the participants at the workshops and CIFOR scientists who helped build the model and develop scenarios. For funding we acknowledge the International Tropical Timber Organisation (ITTO), the Netherlands government and the European Economic Community. The authors are grateful to the many colleagues, notably Douglas Sheil, Carol Colfer, Patrice Levang, Richard Dudley and Jeffrey Sayer, as well as two anonymous reviewers who provided extensive comments and suggestions on earlier drafts of this paper.

\section{REFERENCES}

Andrianto, A. 2006. The Role of District Government in Poverty Alleviation: Case Studies in Malinau and West Kutai Districts, East Kalimantan, Indonesia. CIFOR, Bogor, Indonesia.

Barr, C., Wollenberg, E., Limberg, G., Anau, N., Iwan, R., Sudana, M., Moeliono, M. and Djogo, T. 2001. Case study 3: The Impacts of Decentralization on Forests and ForestDependent Communities in Kabupaten Malinau, East Kalimantan. Case studies on Decentralisation and Forests in Indonesia. CIFOR, Bogor, Indonesia.

Basuki, I. and Sheil, D. 2005. Local Perspectives of Forest Landscapes. A Preliminary Evaluation of Land and Soils, and their Importance in Malinau, East Kalimantan, Indonesia. CIFOR. Bogor. Indonesia.

Boedhihartono, A. K., Gunarso, P., Levang, P. and Sayer, J. 2007. 'The principles of conservation and development: do they apply in Malinau?' Ecology and Society 12(2): 2. [online] URL: http://www.ecologyandsociety.org/vol12/ iss2/art2/

Bruijn, A. de. 2005. Carbon dynamics simulation in Malinau Research Forest, Borneo, Indonesia. Thesis Wageningen University and Research Center, The Netherlands.

Casson, A. 2000. The Hesitant boom: Indonesia's oil palm sub-sector in an era of economic crisis and political change. CIFOR Occasional Paper 29, CIFOR, Bogor, Indonesia.

Colchester, M., Jiman, N., Andiko, Sitait, M., Firdaus, A. Y., Surambo A. and Pane, H. 2006. Promised Land - Palm Oil and Land Acquisition in Indonesia: Implications for Local Communities and Indigenous Peoples Forest Peoples Programme, Perkumpulan Sawit watch, Huma and the World Agroforestry Center, Bogor, Indonesia.

Engel, S., Lopez, R. and Palmer, C. 2006. 'Community-industry contracting over natural resource use in a context of weak property rights: The case of Indonesia.' Environmental and Resource Economics 33 (1): pp. 73-93.

FAO (Food and Agriculture Organisation). 2003. FAO facts and figures, Country information: Indonesia Forests and the Forestry sector [online] URL: http://www.fao.org/spfs/ indonesia/index_en.asp 
Ferraro, P. and Kiss, A. 2002. 'Direct payments to conserve biodiversity.' Science 29: pp.171819.

Gönner, C. 2000. 'Causes and Impacts of Forest Fires: A Case Study from East Kalimantan, Indonesia.' In: International Forest Fire News 22: pp. 35-40.

High Performance Systems. 1996. Stella and Stella Research Software. High Performance Systems, Inc. Hanover NH.

Karky, B.S. 2006. Case study 1: Kafley Community Forest, Lamatar, Nepal In: Murdiyarso, D. and Skutsch, M. 2006. Community Forest Management as a Carbon Mitigation Option. CIFOR, Bogor, Indonesia, pp. 8-15.

Koczberski, G., Curry, G. and Gibson, K. 2001. Improving Productivity of the Smallholder Oil Palm Sector in Papua New Guinea: A Socio-Economic Study of the Hoskins and Popondetta Schemes. The Australian National University, Canberra, Australia.

Koh, L. P. and Wilcove, D. S. 2007. 'Cashing in palm oil for conservation.' Nature 448: pp. 993-4.

Levang, P., Dounias, E. and Sitorus, S. 2005. 'Out of the forest, out of poverty?' Forests, Trees and Livelihoods. 15: pp. 211-36.

Lynam, T., Cunliffe, R., Sheil, D., Wan, M., Salim, A., Priyadi, H. and Basuki, I. 2006 Livelihoods, land types and the importance of ecosystem goods and service: Developing a predictive understanding of landscape valuation by the Punan Pelancau people of East Kalimantan. CIFOR, Bogor, Indonesia.

Lynam, T., Bousquet, F., le Page, C., d'Aquino, P., Barreteau, O., Chinembiri, F. and Mombeshora, B. 2003. 'Adapting science to adaptive managers: spidergrams, belief models, and multi-agent systems modeling.' In: Campbell, B.M. \& Sayer, J.A. Integrated Natural Resources Management: Linking Productivity, the Environment and Development. CABI Publishing, Wallingford, UK.

Mittermeier, R. A. and Bowles, I. A. 1993. The GEF and Biodiversity Conservation: Lessons to Date and Recommendations for Future Actions. Conservation International Policy Papers I. US.

Obidzinski, K. and Barr, C. 2003. 'Case study 9: The Effects Decentralisation on Forests and Forest Industries in Berau District, East Kalimantan.' In: Case Studies on Decentralisation and Forests in Indonesia. CIFOR, Bogor, Indonesia.
Padmanaba, M. and Sheil, D. 2007. 'Finding and promoting a local conservation consensus in a globally important tropical forest landscape.' Biodiversity Conservation 16: pp. 137-51.

Palmer, C. 2004. The role of collective action in determining the benefits from IPPK logging concessions: A case study from Sekatak, East Kalimantan. CIFOR Working Paper 28, Bogor, Indonesia.

Pambudhi, F., Belcher, B., Levang, P. and Dewi, S. 2004. Chapter 22: 'Rattan (Calamus spp.) gardens of Kalimantan: resilience and evolution in a managed non-timber forest product system.' In: Kusters, K. and Belcher, B. 2004. Forest Products, Livelihoods and Conservation: Case studies of Non-Timber Forest Product Systems. Volume 1 - Asia. CIFOR, Bogor, Indonesia.

Paz Soldan, M. and Walter, S. 2003. The Impact of Certification on the Sustainable Use of Brazil Nut (Bertholletia excelsa) in Bolivia. FAO, Rome.

Reinhardt, G., Rettenmaier, N., Gärtner, S., 'ifeuinstitut für Energie- und Umweltforschung Heidelberg $\mathrm{GmbH}^{\prime}$ (chapter 2 and 4), Pastowski, A., 'Wuppertal institut für Klima, Umwelt, Energie GmbH' (chapter 3). 2007. Rainforest for biofuel? Ecological effects of using palm oil as a source of energy. WWF Germany, Frankfurt am Main. [online] URL: $w w w . w w f . d e / f i l e a d m i n / f m-w w f / p d f \_n e u /$ wwf_palmoil_study_english.pdf

Sargeant, H. J. 2001. Vegetation fires in Sumatra, Indonesia. Oil palm agriculture in the wetlands of Sumatra: destruction or development? European Union Forest Fire Prevention and Control Project with Dinas Kehutanan Propinsi Sumatera Selatan. European Union and Ministry of Forestry, Jakarta, Indonesia.

Sayer, J. and Campbell, B. 2004. The Science of Sustainable Development: Local Livelihoods and the Global Environment. Cambridge University Press, Cambridge, UK.

Sheil, D., Puri, R., Wan, M., Basuki, I., van Heist, M., Liswanti, N., Rukmiyati, Rachmatika, I. and Samsoedin, I. 2006. 'Recognizing Local People's Priorities for Tropical Forest Biodiversity.' Ambio 35 (1): pp. 17-24.

Susila, W. R. 2004. 'Contribution of oil palm industry to economic growth and poverty alleviation in Indonesia.' Jurnal Litbang Pertanian 23(3): pp. 107-14. 
Toit, J. T. du, Walker, B. H. and Campbell, B. M. 2004. 'Conserving tropical nature: current challenges for ecologists.' Trends in Ecology and Evolution 19: pp. 12-17.

TTM Report. 2006. Kalimantan Governor Suspended for Plantation Fraud. Tropical Timber Market Report 11(23): pp. 4-5.

Wakker, E. 2006 The Kalimantan Border Oil Palm Mega-project. Aidenvironment. Commissioned by Friends of the Earth Netherlands and the Swedish Society for Nature Conservation, April 2006 [online] URL:http://www.orangutans-sos.org/ downloads/palm_oil_mega_project.pdf
Wunder, S., Campbell, B., Iwan, R., Sayer, J. A. and Wollenberg, L. 2004. When donors get cold feet: The community conservation concession in Setulang (Kalimantan, Indonesia) that never happened. CIFOR, Bogor, Indonesia. 


\section{CHAPTER 5}

FACILITATING COOPERATION DURING TIMES OF CHAOS: SPONTANEOUS ORDERS AND MUDDLING THROUGH IN MALINAU DISTRICT, INDONESIA ${ }^{1}$

Eva Wollenberg, Ramses Iwan, Godwin Limberg, Moira Moeliono, Steve Rhee and Made Sudana 


\section{INTRODUCTION}

Adaptive collaborative management (ACM) has become widely accepted as an approach for facilitating decisions about natural resources in complex, uncertain environments in which decision-making among interest groups is required (Chess et al., 1998; Sinclair and Smith, 1999; Wondolleck and Yaffee, 2000; Buck et al., 2001; Colfer, 2005). However, ACM assumes that cooperation among different groups can be guided in predictable ways. We suggest, to the contrary, that cooperation itself can be chaotic and uncertain, especially during times of political or organisational instability. How can ACM work under such conditions?

In this chapter we show thatadaptivecollaborative management in 'chaotic' institutional contexts can benefit from the recognition and use of spontaneous cooperation among decision- makers. Working with spontaneous cooperation requires special methods that bring particular challenges. We illustrate our case with examples from Malinau District, in East Kalimantan, Indonesia from 1998 to 2005, where our action research team used ACM to facilitate collaboration among communities and government to improve equity, incomes and sustainable forest management, but did so during times of high political uncertainty and instability.

\section{LIMITS TO COLLABORATION}

Adaptive management of natural resources has emerged over the past 20 years as a way of coping with uncertainty, rapid change and the complexity of whole systems (Holling, 1978; Walters, 1986; Poteete and Welch, 2004). Adaptive management is decision-making informed by a learning process: (1) setting management objectives; (2) implementing a decision to achieve the objectives; (3) observing outcomes and assessing against objectives; and (4) as necessary, adjusting the practice though a new decision (Lee, 1993). Drawing on complexity and organisational theory, adaptive managers have tried to become more open to surprise, accident and serendipity, and 'welcome disorder positively' (Axelrod and Cohen, 1999; Rosenhead, 1998:6). They develop explicit learning strategies by seeking newly developing information that suggests new opportunities and emerging patterns in the organisation and its environment (Senge, 1990; Sanders, 1998; Stacey, 2003). Managers seek to have an active, iterative engagement with their environment and work in a flexible, responsive way that builds on their experience.

Monitoring the environment is a key feature of the approach. When different interest groups share a stake in a resource, such as forests, collaborative management can help meet these different groups' needs. ACM is thus adaptive management in which different interest groups engage in the cyclical learning process together (Buck et al., 2001; Colfer, 2005). These approaches work best when strong communication, trust, coordination and legitimate decision-making and authority occur or can be built through improved relationships and institutions (Stacey, 2003; Colfer, 2005).

Unfortunately, under some circumstances, organisations find it difficult to build the relationships and institutions that support collaborative learning. Social unrest and political upheaval can result in a lack of capable institutions to mediate conflict or legitimise decisions. This, in turn, can reduce communication and trust among and within organisations. Organisations can have their own internal crises as well, due to a lack of capacity, leadership crisis, external pressures or internal reform.

Ironically, ACM is intended to cope with complex external contexts, but it has not addressed how to cope with complexity internal to decisionmaking and management. How can decisionmakers cope with their own chaos and not just chaos in their environment?

In this chapter, we focus on this seeming contradiction to ask how collaborative learning is possible in unstable contexts and what methods are required to achieve it. We give special attention to cooperation among decisionmakers for its importance in supporting both collaborative learning and management. 


\section{CHAOS AND SPONTANEOUS ORDERS}

Chaos models provide one way of understanding how ACM practitioners can achieve cooperation under conditions of instability. Chaos theory predicts that when a system moves from equilibrium to instability, it passes through a state of bounded instability in which stability and instability operate at the same time, and cause and effect disappear (Stacey, 2003). We suggest that natural resource managers often face bounded instability during times of massive change, as they face a mix of controllable and uncontrollable conditions such as volatile markets, policy changes, social unrest or natural catastrophes.

We have observed, however, that practitioners of $\mathrm{ACM}$ readily recognize chaos and bounded instability in their environment, but rarely address it in their own decision making. ACM can benefit from work in organizational learning theory that acknowledges internal chaos and identifies its predictabilities (Senge, 1990; Stacey, 2003).

According to organisational learning theory, during bounded instability, behaviour has a spontaneous, self-organised emergent pattern that is irregular and highly complex (Stacey, 2003). The emergent pattern often occurs at new scales, e.g., smaller or larger groups, longer or shorter decision-making cycles. The pattern is itself subject to variation with small changes in the environment, and it is impossible to know the long-term future.

Hot groups are an example of such an emergent pattern and have been prescribed by some as a way for organisations to be more responsive to rapidly changing environments (Lipman-Blumen and Leavitt, 1999). Hot groups do not constitute a structural unit in an organisation. People come together voluntarily and spontaneously because of common interests. The groups organise themselves quickly, are flexible and have high motivation and capacity for innovation.

When bounded instability occurs among ACM decision-makers, cooperation among them can thus be viewed as a self-organised, spontaneous, emergent pattern that is likely to take place at scales different from what ordinary, formal decision-making would suggest. Scale refers here to different levels or degrees of social organisation or decision-making. The emergent, spontaneous order of cooperation cannot be guided by a single organisation or hierarchical entity. Instead, people pursue their own ends and mutually adjust to each other to form cooperative arrangements across the boundaries of their usual activities. In the remainder of the chapter, for ease of reference, we use the terms 'spontaneous orders of cooperation', 'spontaneous cooperation', or 'orders' interchangeably.

Spontaneous orders of cooperation can have advantages over designed cooperation. Competition can exist among parties and can promote more rigorous outcomes as it does in the self-organised practice of science, free markets, or democracy (di Zerega, 2000). Spontaneous orders of cooperation can also incorporate more complex relationships and information as they are not limited by people's cognitive and organisational skills (di Zerega, 2000).

One of the disadvantages, however, is that spontaneous orders tend to be dissipative structures (Nicolis and Prigogine, 1989) that require 'great effort to retain its structure and relatively little to change it', in contrast to the equilibrium structure that 'requires no effort to retain its structure and great effort to change it'. (Stacey, 2003:226). Staying in this state is therefore not efficient, as it requires continuous inputs of energy, attention and information (Rosenhead, 1998; Stacey, 2003). However, managers can benefit from the innovation and opportunities they yield.

Chaos models therefore suggest that it may be imprudent to engineer formal cooperation during times of instability. Rather, people should try to work with spontaneous orders of cooperation as they emerge. By better understanding spontaneous cooperation, certain elements of what appears to be chaos become more predictable. Efforts should be directed at identifying the more predictable opportunities for cooperation and being responsive to how those opportunities change. It should be recognised that trying to maintain or manage spontaneous orders of cooperation may be expensive due to the requirement for continuous inputs and 
the difficulty of predicting how the orders will evolve.

\section{MALINAU AND THE POLICY TRANSITION}

Decentralisation has led to the creation of new districts in Indonesia, and Malinau was formed in October 1999 as a split-off from the District of Bulungan (see Gunarso, this volume). The district pieced together its staff largely from local teachers, educated villagers and lowerlevel administrators. Malinau's administrative capacities were thus extremely weak. Most officials were poorly informed about policy, and many lacked experience. For example, the district forestry service, land registering agency and coordinating agency could not agree about the ownership status of forest land in the district or the legal basis for allocating it.

Because reforms created a mandate for more populist politics, some officials made exorbitant promises to communities. Communities, in turn, made exorbitant demands and happily exercised their right to disregard government authority. Communities and officials tried to work out deals with each other and with the timber companies that would best serve their interests. There was no model or standard that people could follow to gauge what was the 'right' behaviour in the new system. Everything was fluid and up for grabs.

The turmoil of the transition lessened in 2003 as small-scale timber licences became illegal and officials settled into their roles. However, enormous uncertainties persisted. In 2006, district government and local people still contested their roles in forest management and how the forest should be used.

\section{Facilitating collaboration}

In Malinau, policy reforms enabled ethnic divides and competition across all sectors of society to give some people new influence, while marginalising others, especially communities in forest areas. The Center for International Forestry Research (CIFOR) sought to assist forest communities to increase their access and control over forest benefits and decisions. This aim included trying to improve both income opportunities for communities and their rights to forest land and management.

We used ACM with local partners to determine interventions. As researchers used to facilitating information flows, our interventions focused on improving communication, joint learning, conflict management and deliberation. We facilitated relationships among communities and between communities and government. Activities focused on the 27 forest villages in a single watershed near Malinau in which forest management and income opportunities were especially volatile. CIFOR was committed to working in this part of Malinau as a long-term research site. Individuals from the communities and government participated as partners and beneficiaries.

Our core team, i.e., the 'CIFOR adaptive co-management team', drove the adaptive learning process by periodically reflecting upon our activities and revising our strategy for interventions. We monitored our impact through routine surveys of villages every 3-6 months, as well as through evaluations of major activities. Informal observation of experiences was also important. The team of 5-7 members had expertise in community outreach, forest conservation, community-based management, mapping, anthropology and agriculture, with long-term experience in Kalimantan. Three members were from local villages.

Initiated in 1998, our work had five components. Each component served as a learning cycle that informed the next:

\section{Village surveys and monitoring to understand local concerns and conditions:}

We conducted surveys in 1998 to orient ourselves to design locally relevant programmes. We found it useful to continue visits to villages to monitor reform developments and our impact. Villagers or government officials sometimes participated. Monitoring included observations of the forest, as well as economic, political and social conditions.

\section{Participatory mapping and village agreements:}

In response to villagers' interests to demarcate their customary lands, we mediated conflicts 
over village boundaries and facilitated mapping among villages from January to July 2000 . The team did not complete the mapping due to the difficulty of maintaining boundary agreements and lack of endorsement from the district government (Anau et al., 2002). The reform period was at its most chaotic during this time. The experience indicated that Malinau lacked institutions to secure legal recognition of claims to land. To address this gap, we worked with local people and officials to develop principles to develop stable agreements and manage conflict.

\section{Legal awareness and policy dialog:}

Following the need for improved institutions, starting in 2001 we facilitated awareness-building and policy dialogue among government officials and communities about multi-stakeholder land-use planning, public participation, representation, customary rights and the use of public forests as sources of village revenue. We shared information on these topics through informal discussions, policy briefs, newsletters, sharing of the regulations and laws, workshops and cross-site visits.

\section{Community participation in district land-use planning:}

In 2001, Malinau started the preparation of a land-use plan, rencana tata ruang. We saw this as a practical opportunity to enable communities to have more influence over forest decisions and access to forest land. We worked to link village and district-level land-use decisionmaking. Relationships with the district were cool. Officials distrusted our motives, as our aim was to empower communities. Although we established a MOU, several committees and a workplan with the district, the formality of these measures only distanced us further.

Few villagers knew that the district was developing a land-use plan, so we helped them analyse their land-use priorities and report these to the district. Officials and the technical consultants did not value the input from villagers. We had difficulty coordinating with officials, as their schedules changed frequently at the last minute. The interest in collaboration of the more powerful community and government groups declined when they realised there was no money available, whereas more marginalised groups increasingly sought us out.
It was during this time that we first recognised the importance of spontaneous cooperation. Watching the plethora of deal-making around us, we realised that officials and villagers were able to cooperate easily enough with one another to exploit timber, and found this more interesting than our efforts to support formal land-use planning. To increase our relevance to communities and the government, we decided to 'go with the flow' to facilitate villages in identifying forest-based enterprise options that could be supported by government. We took a more flexible, informal approach and worked with fewer villages to give them more individualised attention.

\section{Village economic development and land use:} In 2002 we began facilitating the development of new economic uses of forest in four villages. We developed a congenial collaboration with the newly formed District Village Empowerment Service (PMD), which shared similar values of community development and had few vested interests in timber. Unfortunately, PMD was not a very powerful agency, and again, villagers saw little responsiveness to their requests for enhancing gaharu, rattan, or rubber production in their areas.

In this final phase, we worked more directly with communities again, as collaboration with the district had created more of a burden than a help. With some facilitation, villagers undertook inventories of their community forests to assess the potential for their preferred land-use plan and drew up future scenarios, management plans and work plans. With officials, we relied on coincidental convergences of interests to guide collaboration rather than trying to plan. For example, in 2004 we sponsored a provincial research and development office to train local people how to inoculate Aquilaria trees with a fungus to produce gaharu, a fragrant wood worth up to USD $1,000 / \mathrm{kg}$. One of the government officials at the workshop suggested to the district leader that the local government initiate a gaharu planting programme. Six months later the district launched their 'Movement for planting one million gaharu trees'. As the inoculation carried out during the training yielded positive results, communities purchased and planted hundreds of gaharu seedlings in mid-2005. 


\section{Facilitating by muddling through}

Our capacity to be flexible in our facilitation strategy was key to working with spontaneous cooperation. We made adjustments by 'muddling through' (Lindblom, 1959), using the limited information available and evaluating only a few, incrementally different alternatives at a time. Muddling through is thought to yield positive outcomes when the outcomes of decisions are hard to predict, and so the risks of radical change are high (Bendor, 1995). Muddling through is also a practical way to make sense of the messiness of complexity (Bernstein and Fortun, 1998). We suggest such muddling is more realistic than the more comprehensive and routine information requirements suggested by more formal scientific adaptive management practice or participatory action research.

Each cycle of activity evolved in the context of work that preceded it and reflected our own deeper understanding and long-term presence in Malinau. Over time, we found that small, but incrementally significant achievements occurred because of fortuitous circumstances, e.g. a chance meeting with an influential person, a coincidence of interests among key actors, an unexpected event providing an opportunity for influence. An issue raised coincidentally with the right person at the right time resulted in action. These coincidences became as important to achieving our objectives as our purposeful activities. We learned to increase the possibility for these opportunities through four tactics.

The most important tactic was to have staff physically present in the area and interact often with different groups. By 'being around', we increased our opportunities for informal interactions with people, which was more conducive to building trust and relationships. We also increased the likelihood of chance meetings with the gatekeepers. These were people with authority, influence and control the movers and shakers who could short-cut the bureaucracy and get things done. These included the district leader and agency heads who, under formal circumstances, would have been harder to meet and were less communicative. Other people were able to find us more easily to provide information they thought we needed to know, including invitations to events, news of cancelled plans, their understanding of hidden motives, or an alternative interpretation of the discourse surrounding an issue. Opportunities for spontaneous cooperation with more marginalised groups also increased, as they became more confident in knowing where to find us.

The second tactic was to work informally and build relationships with the support network of the gatekeepers. The support network included people who advised or influenced the gatekeepers, people who knew and organised schedules, and people who had the latest inside information about decisions. From these interactions we were able to learn the timing of ad hoc gatherings and events, and the interests that motivated different groups to participate in different events. These factors were the key determinants of being able to engage with spontaneous cooperation in Malinau.

The third tactic was to maintain multiple strands of activities with different stakeholders. We found it easier to have separate programmes of work among communities and local government, rather than one joint programme. In this way, the priorities of different groups could be met, there was less need for coordination, and one group did not depend on another to take action. For example, one village was more concerned with developing opportunities for commercial timber production and harvesting, whereas another wanted to stop logging and promote ecotourism. We worked with each independently, while also facilitating districtlevel officials to discuss priorities for the district land-use plan. Nevertheless, we continued to create opportunities for groups to meet.

The fourth tactic was to maintain hyper-flexibility in our schedule and resources. We learned to be ready to reorganise our plans and reallocate staff at the last minute to take advantage of sudden opportunities, as well as routinely adjust our strategy. Maintaining this flexibility was the most difficult, costly and frustrating aspect of facilitation. It required adequate contingency funds to cover changing travel or workshop plans. However, it also reaped significant gains at times, enabling us to have more frequent engagement with policy-makers and catch timely opportunities for having policy input. Being flexible meant accepting inefficiencies; hence the aptness of the muddling metaphor. 
We explicitly acknowledged the risks and inefficiencies that team members encountered and tried to provide them with extra support to cope with it. Ultimately, there were limits to the risk and inefficiency that we could tolerate, and we needed regularly to evaluate overall gains or losses.

Our most successful efforts at institutionalisation were in building capacity of individuals and in working with like-minded agencies. In the spirit of working with spontaneous cooperation, we felt that it would be unwise to invest in more intensive institutionalisation. We do not expect the meetings we have facilitated to be continued in their current form, but we do expect that the types of relationships and activities in which communities and government engage will be affected. In this way, we may have had a small impact on future collaborative learning.

\section{Outcomes}

Our muddling efforts had some outcomes and impacts according to evaluations conducted in 2003 and 2006 by people external to our programme. Although there were few hard, visible changes in forest benefits and influence over decisions in communities, the intermediate outcomes of building collaboration and new awareness were significant. According to a 2003 survey of 52 villagers, most respondents felt that the programme:

- Expanded our thinking, thereby helping us to understand conditions elsewhere, increasing our information and experience, and providing feedback about our situation;

- Helped our community advance and develop, and provided input to community through advice and explanations;

- Improved relationships among villages, reduced conflicts, and helped with boundaries;

- Helped to bridge communities and government; and

- Improved awareness about forest conservation.

Villagers also observed that the programme created little tangible economic benefit for communities and were frustrated that CIFOR did not take a more active role in technical forest management or income generation. People were most pleased with the gaharu inoculation activity for its direct economic value. One village also successfully protected its forest with help from the programme. Some officials, particularly in the district forestry department, were predictably negative about our work, as it exposed and discouraged the uncontrolled nature of logging in Malinau.

Generally, less influential villagers and government organisations were more positive about the impacts of our work. The mix of views and interests in collaboration reflected the reality of the values of the different groups involved. In a project intended to empower a marginalised group, it may be difficult to prevent other groups from feeling threatened. Facilitating collaboration requires specific strategies for dealing with each group. It also means being prepared to have some groups trying to undermine your goals and dealing with conflict with authorities.

Over time, as the district established itself and CIFOR became a better known and trusted entity, responses became even more positive. In the 2006 survey of 65 people, i.e., 28 villagers from 13 villages and 37 government officials, $80 \%$ of the respondents agreed that the results of CIFOR's research, including non-ACM projects, were useful for improving their knowledge about forests and conservation. Nearly all, i.e., 97\%, said it was important for CIFOR to continue working in Malinau.

The responses suggest thatfacilitating cooperation and shared learning are valued, despite their intangibility. In common with Castellanet and Jordan (2002), we believe that the greatest accomplishment of this type of action research is change in capacities and attitudes. Getting different groups to talk freely with each other about their needs is already a big achievement (Hagmann, 1999). We hope that over time, these small changes will support concrete action.

Working with spontaneous cooperation made the chaotic environment more predictable and manageable. Although we might have been more effective in a more stable environment, we did not have that choice due to the institutional commitments of CIFOR to Malinau. We believe that many decision-makers find themselves in similar situations in which they have to cope with chaos, whether they want to or not. 
Although working in a less chaotic environment would have been more efficient, working in chaotic environments may have other advantages. The relationships formed under often dramatic circumstances built deeper levels of trust than otherwise possible in a short time. People were more receptive to innovative ideas and social arrangements. Our goal of empowering marginal groups might have been less successful working with more entrenched policies and social structures.

\section{CONCLUSION}

Existing models of ACM or other simple platforms for collaboration (Hemmati, 2002) are unlikely to work in places like Malinau, at least not with socially just and long-term outcomes. These approaches presume communication and trust exist or can be built easily, and that clear institutions for deliberation, agreements, checks and balances, and managing conflict are in place. In Malinau, and elsewhere with weakly developed civil society or states with low capacities, these conditions do not exist. The high transaction costs of collaboration and possibilities for co-optation or unsustainability are too high.

The alternative, as chaos theory helps to show, is to learn to work with spontaneous orders of cooperation. Working with spontaneous cooperation requires a more embedded and informal approach that includes being physically present in an area; maintaining close relations with the people who support gatekeepers; developing programmes for multiple interest groups; and being hyper-flexible. This approach identifies and builds on predictabilities that exist in chaotic systems.

This form of adaptive management requires acceptance of a 'muddling through' attitude and coping with the resulting risk and inefficiencies. Learning opportunities need to be built into schedules explicitly, with generous amounts of time allowed. Reflection processes need to be creative and efficient so as to maintain their appeal. Facilitation strategies need to be flexible enough to respond to changing opportunities, yet not change so often that other groups do not understand the purpose or direction of the work.
In Malinau, adjusting strategies about once a year seemed to work. These changes were incremental and built iteratively upon earlier strategies. Adjustment does not mean abrupt departure from objectives and established processes. Facilitators need to allow enough time to really test and evaluate their strategies before they change them.

The strength of the informal, muddling approach to adaptive management is that it can increase the relevance of facilitation to local circumstances. Information is more accurate, indepth and comprehensive, especially in terms of hearing different perspectives from different groups. Facilitation more closely mirrors how local policies are made and therefore enables the facilitators to take advantage of different waves of opportunity to initiate new cycles of work and to engage different groups at times of maximum impact. It is more possible to carve out the space to work independently, as we did with villagers on their proposals to government or village land- use plans, or to monitor village conditions with officials in the Community Empowerment Service without battling the resistance of other offices. Officials are less likely to co-opt the agenda. Social relationships are more embedded.

The weakness of this approach is that it entails risks and inefficiencies. As chaos theory suggests for dissipative structures, spontaneous cooperation requires continuous input to be maintained. The frustrations and constant reallocation of resources associated with hyperflexibility can impose severe costs. The approach requires a team that can be tolerant of such demands and have the forbearance to sustain their own motivation. When working more informally, it can be hard to have the same level of transparency and credibility acquired through more formal cooperation. Special efforts need to be made to get the endorsements of gatekeepers and to share information intensively.

From a research perspective, it is more difficult to collect consistent information for comparisons. Despite the weaknesses, such approaches may be the best choice for facilitators in unstable times. Muddling is often the only practical option. The facilitator needs to judge whether enough incremental gains are being made in a given period to warrant the effort and the 
opportunity costs of the efforts. Sometimes it will be better to wait for more stable conditions, although there can be less room for innovation or building relationships during such times.

The selection of methods in any site is itself an iterative and adaptive 'muddling' process. We do not suggest that the approach we took in Malinau is necessarily the best to take elsewhere. These decisions are highly dependent on resources available to the facilitators, their own capacities and the environment in which they are working. We think that these sorts of approaches contribute to a more democratic and feasible means of facilitating change. Our goal has not been directly to facilitate collaboration; rather it has been to create an enabling environment for accommodating interests and their coordination, especially of weaker groups. This is a messy, muddling process, but it is also a reality of political change.

\section{ACKNOWLEDGMENTS}

We thank our partners that collaborated in the ACM programme in Malinau, including the Bulungan and Malinau district and sub-district offices, including the Agency for Planning, Forestry Service, Community Empowerment Service, Agricultural Service, Economy Service, Law Unit, INHUTANI II, Meranti Sakti (another local timber concession) and the provincial Forest Service. We have also collaborated with Plasma, SHK-Kaltim, PPSDAK, Padi, LPMA, Phemdal, WWF, P-5-Universitas Mataram, the University of Victoria (Canada), Wageningen University and Yale University in various components of the work.

\section{REFERENCES}

Anau, N., Iwan, R., van Heist, M., Limberg, G., Sudana, M. and Wollenberg, E. 2002. Negotiating more than boundaries: conflict, power, and agreement building in the demarcation of village borders in Malinau.' Pp. 131-56 in CIFOR. Forest, science and sustainability: the Bulungan Model Forest. ITTO project PD 12/97 Rev.1 (F): Technical Report Phase 1, 1997-2001. CIFOR, Bogor, Indonesia.
Axelrod, R. and Cohen, M. D. 1999. Harnessing complexity: organizational implications of a scientific frontier. The Free Press, New York, New York, USA.

Barr, C., Wollenberg, E., Limberg, G., Anau, N., Iwan, R., Sudana, M., Moeliono, M. andDjogo, T. 2001. The impacts of decentralization on forests and forest-dependent communities in Kabupaten Malinau, East Kalimantan. CIFOR, Bogor, Indonesia.

Bendor, J. 1995. 'A model of muddling through'. American Political Science Review 89(4): pp. 819-40.

Bernstein, H. J. and Fortun, M. 1998. Muddling through: pursuing science and truth in the twenty-first century. Counterpoint Press, New York, New York, USA.

Buck, L. E., Wollenberg, E. and Edmunds, D. 2001. 'Social learning in collaborative management of community forests: lessons from the field'. Pp. 21-44 in E. Wollenberg, Edmunds, D., Buck, L., Fox, J. and Brodt, S., editors. Social learning in community forests. CIFOR, Bogor, Indonesia.

Castellanet C. and Jordan, C. F. 2002. Participatory action research in natural resource management: a critique of the method based on five years' experience in the Transamazonica Region of Brazil. Taylor and Francis, Ann Arbor, Michigan, USA.

Chess, C., Dietz, T. and Shannon, M. 1998. Who should deliberate what? Human Ecology Review 5 (1): pp. 45-8.

Colfer, C. J. P., editor. 2005. The complex forest: communities, uncertainty and adaptive collaborative management. Resource for the Future/CIFOR, Washington, D.C., USA.

Di Zerega, G. 2000. Persuasion, power and polity: a theory of democratic self-organization. Hampton, Cresskill, New Jersey, USA.

Hagman, J. 1999. Learning together for change. Margraf Verlag, Werkershein, Germany.

Hemmati, M. 2002. Multi-stakeholder processes for governance and sustainability: beyond deadlock and conflict. Earthscan, London, UK.

Holling, C. S. 1978. Adaptive environmental assessment and management. John Wiley and Sons, New York, New York, USA.

Lee, K. N. 1993. Compass and gyroscope: integrating science and politics for the environment. Island Press, Washington, D.C., USA. 
Limberg, G., Iwan, R., Moeliono, M., Sudana, M. and Wollenberg, E. 2004. 'It's not fair, where is our share? The implications of small-scale logging on communities' access to forests in Indonesia'. Paper presented at the Meeting of the International Association for the Study of Common Property, 9-13 August 2004, Oaxaca, Mexico and at the International Conference on Land and Resource Tenure, Questioning the Answers, 11-13 October 2004, Jakarta, Indonesia.

Lindblom, C. E. 1959. 'The science of "muddling through" '. Public Administration Review 19 (2): pp. 79-88.

Lipman-Blumen, J. and Leavitt, H. 1999. Hot groups: seeding them, feeding them, and using them to ignite your organization. Oxford University Press, New York, New York, USA.

Malinau Voting Census. 2003. Malinau voting census data. Regional Government of Malinau District, East Kalimantan Province, Indonesia.

Nicolis, G. and Prigogine, I. 1989. Exploring complexity: an introduction. W. H. Freeman, New York, New York, USA.

Poteete, A. R. and Welch, D. 2004. 'Institutional development in the face of complexity: developing rules for managing forest resources'. Human Ecology 32(3): pp. 279 311.

Rosenhead, J. 1998. Complexity theory and management practice. Available online at: http://www.ecologyandsociety.org/vol12/ iss1/art3/ and www.human-nature.com/ science-as-culture/rosenhead. html.
Sanders, T. I. 1998. Strategic thinking and the new science: planning in the midst of chaos, complexity, and change. The Free Press, New York, New York, USA.

Senge, P. M. 1990. The fifth discipline: the art and practice of the learning organization. Currency Doubleday, New York, New York, USA.

Sinclair, A. J. and Smith, D. L. 1999. 'The model forest program in Canada: building consensus on sustainable forest management?' Society and Natural Resources 12: pp. 121-38.

Stacey, R. D. 2003. Strategic management and organisational dynamics: the challenge of complexity. Fourth edition. Financial Times/ Pearson Education, Edinburgh, UK.

Sudana, M., Iwan, R., Limberg, G., Moeliono, M. and Wollenberg, E. 2004. 'Winners take all: understanding forest conflict in the era of decentralization in Indonesia'. Paper presented at the Meeting of the International Association for the Study of Common Property, 9-13 August 2004, Oaxaca, Mexico and at the International Conference on Land and Resource Tenure, Questioning the Answers, 11-13 October 2004, Jakarta, Indonesia.

Walters, C. 1986. Adaptive management of renewable resources. MacMillan, New York, New York, USA.

Wondolleck, J. M. and Yaffee, S. L. 2000. Making collaboration work: lessons from innovation in natural resource management. Island Press, Washington D.C., USA.

Wulan, Y. C., Yasmi, Y., Purba, C. and Wollenberg, E. 2004. Analisa konflik sektor kehutanan di Indonesia 1997-2003. CIFOR, Bogor Indonesia. 


\section{CHAPTER 6 INTERACTIVE LAND-USE PLANNING IN INDONESIA RAINFOREST LANDSCAPES: RECONNECTING PLANS TO PRACTICE ${ }^{1}$}

Eva Wollenberg, Imam Basuki, Bruce M. Campbell, Erick Meijaard, Moira Moeliono, Douglas Sheil, Petrus Gunarso and Edmound Dounias 


\section{INTRODUCTION}

Governments around the globe use land-use plans to establish policies, whether for zoning protected areas, managing community forest or coordinating users across a landscape (Theobald et al., 2000; Haddock, 1999). Plans provide guidelines for future decisions, as well as accountability and transparency, by enabling people to articulate management objectives and assess outcomes against goals (Mintzberg, 1993; Lusiana et al., 2005; Lloyd and Peel, 2007). The emphasis on producing plans, however, skews attention to one-off processes that often have little to do with real opportunities for planning local action, especially where government capacities for resource management are weak, legal enforcement is poor, information is lacking, boundaries and access rights are insecure or unclear, and conflicts over resources persist.

Plans under these conditions act as binding frameworks that limit management, rather than as platforms that support it. They establish predetermined schedules, budgets, spatial arrangements and outcomes at the cost of setting in place processes that could support more flexible adaptation and innovation. Even as tools for accountability and bureaucratic control, their use is limited because they quickly lose any claim to relevance. Local land users feel no ownership of the plan and their rights are often ignored. Conventional planning in such contexts gives government and land-use managers a false sense of control that can lead to inattentiveness to critical threats or opportunities.

We suggest an alternative approach that draws from adaptive management, systems theory and multi-stakeholder principles. Planning in this approach shifts from being a preparatory, document-focused effort to a set of decision tools, principles and processes that enables exchange of information, learning and adjustment among government and land users and managers towards a common vision.

This chapter reports on efforts to test this alternative approach during a seven-year period of engagement by the Centre for International Forestry Research (CIFOR) in Malinau District (East Kalimantan Province, Indonesian Borneo). We describe land-use planning in Indonesia and Malinau and its record of relevance. We then introduce an alternative model of planning based on five principles and provide examples of how these principles were applied in Malinau. We conclude with some views about how to overcome the problems of planning in uncertain and complex environments.

\section{LAND-USE PLANNING IN INDONESIA AND MALINAU}

\section{Indonesian planning procedures}

In Indonesia, spatial land-use planning was introduced in 1992 (Act 24) as a foundation for development planning. National, provincial and district entities are required to create land-use plans that reflect land characteristics, potential resources, development challenges and administrative boundaries (Auricht and Rais, 2000).

Most people, including those in government, have come to view the plans as almost meaningless exercises. Jakarta-based consulting companies prepared plans in their offices, rarely if ever making field visits or having good maps or data. Plans were often photocopies of plans from other districts and provided routine information about every sector, regardless of its local relevance. Requirements for public participation were ignored. Government officials colluded with the private sector to allocate land in ways that would personally benefit them. Plans sometimes took decades to translate into legal policy instruments and were seldom shared publicly (Auricht and Rais, 2000). The relevance of plans to the sustainable management of forests was questionable. In East Kalimantan, the plans ignored many of the watershed protection forests and protected areas proposed in Indonesia's National Conservation Plan in 1981/1982.

After Indonesia's decentralisation reforms in 1999, districts gained the authority to make land-use plans to determine the location of development interventions and related permits. The plans are legalised through a district regulation and valid for 10 years with evaluation after five years. Many districts made new plans as a way to express their new-found autonomy 
(cf Mintzenberg, 1993). Yet many of the old problems of land-use planning have persisted.

A new problem is that districts make their plans independently of the provincial plans. The province of East Kalimantan revised its spatial plan in 1999, yet it has not been approved due to conflicts with the many new district plans. The revised decentralisation law in 2004 (Law 32) re-installed the province as a coordinating body, but plans have not as yet been coordinated. Many people see the current planning system as a tool for legitimising private access to district resources with little protection or concern for the public interest.

\section{Land-use planning in Malinau District}

Malinau developed its district land-use plan in 2002. A Jakarta-based consultancy firm made the plans with little or no public participation or field visits. The consultant prepared maps based on information from the previous district of Bulungan and on conversations with district officials about the development intentions. Extensive ecological, forest and social data assembled by CIFOR were virtually ignored. The consultants presented the work at a public hearing in the district capital that included officials and CIFOR invitees but no representatives from Malinau's forested areas. No villagers knew about the land-use plan.

During subsequent closed negotiations in 2003, the district increased the amount of conversion forest by nearly $600,000 \mathrm{ha}$, decreased reserves and limited production forest to make land available for oil-palm development and increase their control vis-à-vis the national government over land and timber revenues (Andrianto, 2006). The decision was made in spite of technical suitability measures indicating the land should remain under forest cover. After several rounds of minor revisions, the plans were finally adopted and legalised in 2003.

The district did not make the final plan public. Our own efforts to see a copy of the plan were always rebuffed. Secrecy helped the district to accommodate investors without public scrutiny. In 2004 a new investor requested a block of land for an oil-palm plantation. The land included part of an existing timber concession and forest where conversion was not permitted. The district subsequently reduced the concession of the parastatal company Inhutani II from 48,000 ha to less than 28,000 ha in the land-use plan. In February 2005, Malinau submitted the revision to the Minister of Forestry for approval, but it was refused. The local government signed the memorandum of understanding with the investor anyway. The provincial government later accommodated the conversion request in its ten-year plan, but in 2006 the Minister of Forestry rejected the province's plans to convert 1 million hectares of forest to oil palm.

In our view, the resulting content of the plan was as disappointing as the process. The plan emphasised forest conversion and plantation development, which would require intensive soil inputs and erosion control, and decrease the control of local people over land and livelihoods. It did not recognise the appropriateness of maintaining forest cover for the area or make provisions for sustainable forestry (Meijaard et al., 2005). Based on analysis of 600 soil samples and 200 site characterisations, using land and soil criteria developed by the Indonesian Department of Agriculture, Basuki and Sheil (2005) found that all 200 sites were unsuitable for the sustainable production of cash crops such as pepper, coffee, rubber or oil palm. The best sites for plantations were the alluvial plains along rivers where local people lived and cultivated their crops. The plan did not recognise that existing cultivation systems were sustainable only because local people used small amounts of land, chose the best sites, maintained vegetative cover, used long fallows in which crop nutrition was derived from vegetation, through burning, rather than from the soil, and rarely cultivated the same crop or field two years consecutively (Dounias and Loutrel, 2002; Basuki and Sheil, 2005).

\section{PRINCIPLES FOR AN ALTERNATIVE MODEL OF PLANNING AND MANAGEMENT}

Prescriptive plans inherently leave little room for discretionary decision-making and flexibility 
(Lloyd and Peel, 2007). Planners often discourage public participation, despite good intentions (Friedman, 2003) because they see their jobs as technical rather than political, and participation can be costly. Strategic decisions are therefore often made outside formal plans (Quinn, 1980 in Stacey, 2003: 71), because decisions have to be made incrementally over time, not all at once.

These simplifications and the technical focus of plans are 'basic givens of modern statecraft' that allow governments to rationalise and standardise reality into a 'convenient format' (Scott, 1998:6). They make the world more readable and controllable. They are an act of 'form-giving' (Forester, 1989: 120) that accommodates bureaucratic needs of control through rules, prescriptions and simplification (Scott, 1998). Yet the cost is that they do not address diverse contexts, change or ambiguity and they are vulnerable to disturbance. Such plans quickly become irrelevant where control and prescriptions are not possible or desirable, especially where political regimes are unstable, policies are in transition, natural environments change, or high levels of innovation are needed.

How then can people conduct land-use planning in more relevant ways? On the one hand, conventional planning produces clear rules that signal obligations and interests in efficient, transparent language that decision-makers need; on the other, complex worlds demand practical local knowledge, discretionary decision-making, social processes and adaptation (Rose, 1994). We argue that land-use planning should link and balance these two approaches at multiple levels. Land-use planning becomes not just a set of designations and control points, but also an iterative process based on practical experience and communication among different groups at different scales. Local practical knowledge and technical systems interact to allow formal decision-makers to cope with a more ordered and simplified world, but as part of a process that better reflects the real evolving local conditions and uncertainties that ordinary people face. $A$ plan thus becomes only a small part of what a district land-use planning team should be doing.
To achieve these aims, an alternative approach to land-use planning should be based on:

(1) Linking local knowledge, experience and aspirations of different groups to formal landuse planning and decision-making (including discussions on tenure and rights).

(2) Developing the adaptive capacities of leadership and institutions through better communication and involvement of local land users and managers; mechanisms for transparency are necessary.

(3) Using system frameworks for understanding land use as a process and anticipating change. Identify drivers of change and possible scenarios associated with different land-use options, including trade-offs among objectives.

(4) Using analysis and intervention at multiple levels, including provincial and national levels.

(5) Building capacity through explicit activities and procedures.

Using these principles allows planning to become an 'activity of making sense together' in practical ways (Forester, 1989: 120), and not a bureaucratic exercise or tool for advancing limited interests.

\section{Linking local knowledge, experience and aspirations to formal land-use planning.}

Unless planning is embedded in local governance, and unless there is ownership of plans at different levels, land-use plans will end up as reports on shelves and as unused GIS layers. Civil society must lobby for greater transparency of planning and access to documents, and proposed and final plans should be available in easy-to-read formats. Public input and review should occur with adequate advance notice and funding from the district. Clarity about tenure and rights is fundamental to understanding who should provide input to land-use plans.

\section{Developing leadership and institutions with adaptive capacity based on communication and involvement of local land users and managers.}

Leadership must be ready to take advantage of opportunities, quickly recognise threats and wisely balance trade-offs. Open and multiple channels of communication, and a commitment to transparency, allow people to challenge, 
debate and exchange information about the appropriateness of plans and when and how to adjust them. Communication needs to take place in politically sensitive but critical ways that feed into local governance structures.

Using system frameworks for understanding land use as a process and anticipating change.

While land-use plans may be appropriate at the time they are produced, in regions of uncertainty and rapid change, plans can quickly be overtaken by new circumstances. Understanding possible trajectories of change from a systems perspective makes decision-makers more attentive to what kinds of changes might occur and how to cope with them (Prato, 2007). Systems-based tools can incorporate local practical knowledge as well as represent changes in simple ways to complement maps.

\section{Analysis and intervention at multiple levels.}

Land-use planning inevitably leads to a focus on a particular scale of analysis. In Malinau this is the district level, but what happens at this level is partially determined by land-use decisions made at lower levels and influenced by decisions at provincial and national levels. Thus multiple levels of analysis and intervention and efforts explicitly to link the different levels are necessary (Sayer and Campbell, 2004). This implies that district planners need to have planning activities in villages, as well as harness the views and perspectives of different stakeholders at other different levels, lobby at higher levels and enable people from different levels to work out agreements together.

\section{Explicit activities and procedures to build capabilities.}

Efforts to improve planningalmostalways focus on technical aspects, forgetting that in many places capacities do not exist to carry these out. Where land-use planning enables more discretionary decision-making, strong governance systems for transparency and more sensitivity and capacity building among decision-makers is necessary (Lloyd and Peel, 2007). Capacities need to be built among both government and civil society members, including sources such as universities or NGOs which can facilitate training and communication.

\section{THE PRINCIPLES APPLIED}

The Centre for International Forestry Research conducted action research in Malinau to support the coordination of land use among multiple users and uses. The work was undertaken in collaboration with the district government and communities from 1998 to 2005 to produce an interactive land-use planning process. In this section we give examples of how this process was supported through application of the five principles.

\section{Linking local practical skills, knowledge and experience of different groups to formal land-use planning and decision-making}

Researchers worked to bridge villagers' and officials' views by making villagers' land-use priorities and land-use decisions more visible. As in many places, Malinau officials viewed local land values and practices as an impediment to development and chose to ignore them in landuse planning. By working directly with farmers and encouraging them to present their ideas, researchers were able to give local values and practices more legitimacy.

In Malinau, boundary issues became contentious as decentralisation reforms made available compensation payments for timber, mining and rights of way, encouraging district and village authorities to maximise their claims over land and forest resources. Competition and alliances among Malinau's many ethnic groups made it almost impossible for the district government to allocate rights among different groups. Formalisation of rights would have resulted in winners and losers, and the district was wary of the possibilities of increased ethnic strife and a decline in political support.

To support villages to establish their claims and better negotiate for benefits with companies and the district, a CIFOR research team facilitated participatory mapping of village boundaries in 2000 among 21 villages (Anau et al., 2001). While the maps were an imperfect solution and alone did not capture the entitlements, they were an important practical tool that communities used to communicate their needs and served 


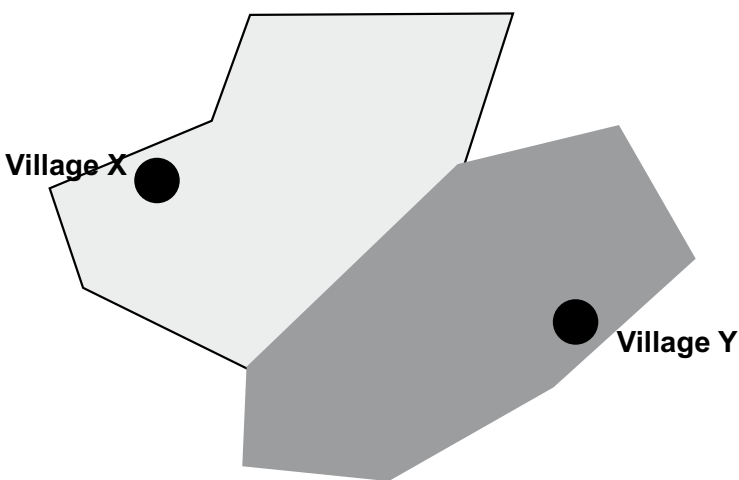

A

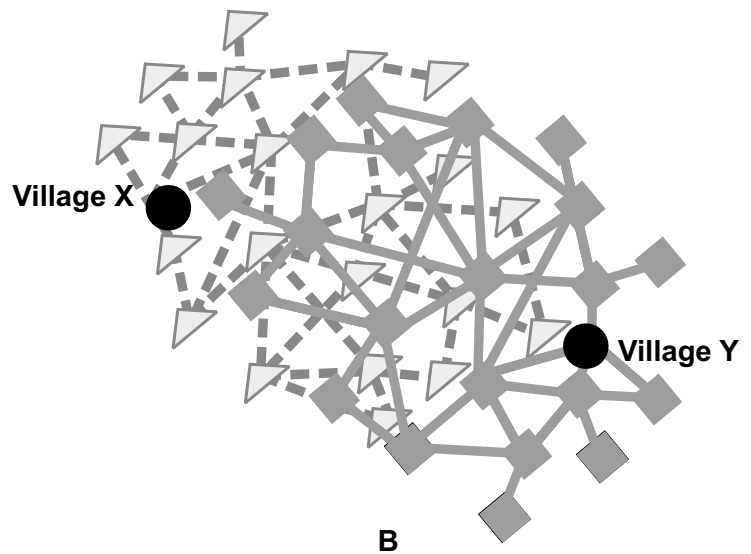

B

Figure 1

as an interface between the formal needs of planners and communities' daily reality.

Researchers then also examined how individuals' access to land depended on their social networks. The research showed that individuals gained access to a vast changing network of sites and forest trails through complex and changing networks affected by inter-ethnic and intervillage relationships. Mapping these lands to identify boundaries or other physical limits was not strictly possible as the networks overlap and are tightly intermingled (Figure 1). Any allocation of formal rights needed to recognise this and allow the flexibility for people to exercise these fluid and socially embedded informal rights.

As threats of forest conversion increased, it became apparent that the district government was unaware or unwilling to recognise local people's perceptions of the landscape and the significance and value they assigned to different sites and services (e.g. Sheil et al., 2006; Lynam et al., in press; Cunliffe et al., in press). For example, local people highly valued old village sites and fruit orchards, and wanted them protected against logging and other damage. Old village sites had heritage value, but also were abundant in fruit species, making fruits such as durian (Durio spp.), coconuts (Cocos nucifera), jackfruit (Artocarpus spp.) and mangos (Mangifera spp.) relatively plentiful and a significant attraction to various frugivores (which local people enjoyed hunting). People also valued the limestone outcrops and caves that are the home of swiftlets (mostly Collocalia spp.) whose nests have considerable cultural and commercial significance and wanted them to establish protected areas around them (as in the 1 kilometre exclusion zones in Malinau (Sheil et al., 2006)).

Officials also tend to undervalue local people's reliance on swidden agriculture and make little effort to accommodate it in land-use plans. Officials made reference to allocating 1 hectare of land per family for permanent agriculture. Yet a study of farmers in Malinau's Tubu watershed showed that choices about the location of the swidden and the type of forest used varied dramatically from year to year (Figure 2).

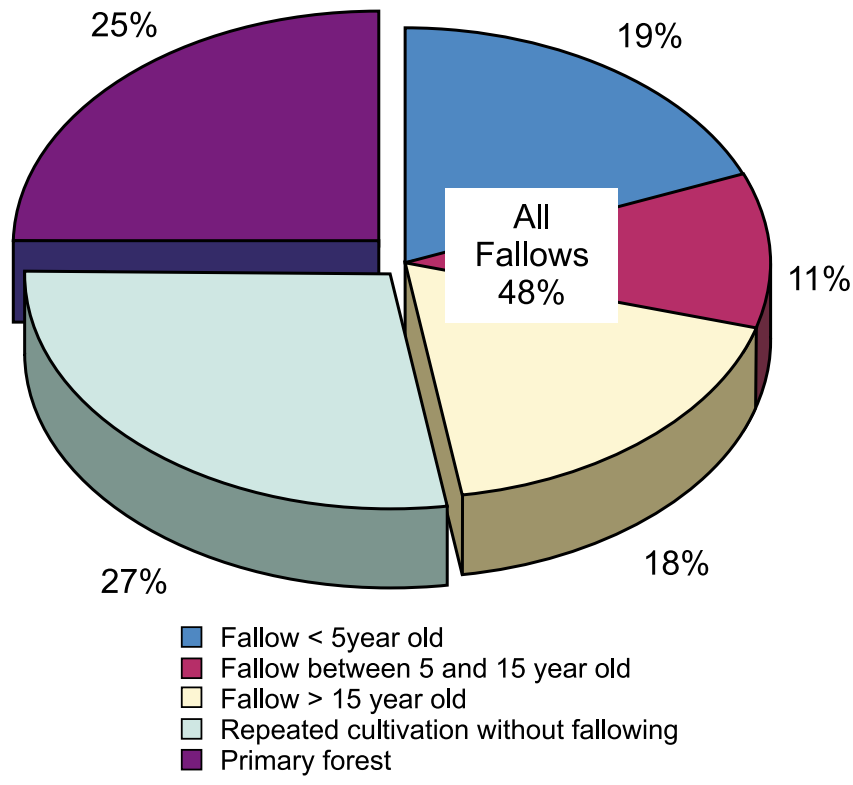

Figure 2 
Fluctuations depended on the composition and availability of household labour, farmers' health status, ever-changing partnerships and alliances among households, and on the balance between agriculture and hunting, fishing and gathering at any one time (Figure 3). In 1994 and 2002, when there was periodic, or mast, fruiting and large numbers of wild bearded pigs in the area, farmers created swiddens from young fallows near the villages, rather than investing in clearing older forests for more productive land. By contrast, in years like 1989 and 1998 to 2000, they made massive clearings in distant primary forest or very old fallows. Dipterocarp forests are subject to severe inter-annual fluctuations that affect the strategies of forest-dwellers and can significantly impact on how land is used. Assessing the land needed in 1994 would have led to a detrimental underestimation of the land cover they actually need to practise swidden agriculture.

\section{Developing the adaptive capacities of leadership and institutions through better communication and involvement of local land users and managers}

Researchers also worked to bridge different groups to enable them to communicate their own values and practices directly with one another and participate in decisions that affected them. This communication and involvement was essential for decision-makers to develop the capacity to adapt to different local conditions and changes.

The project team shared ideas about adaptive management and built communication channels among communities, and between communities and the district government. Multi-stakeholder

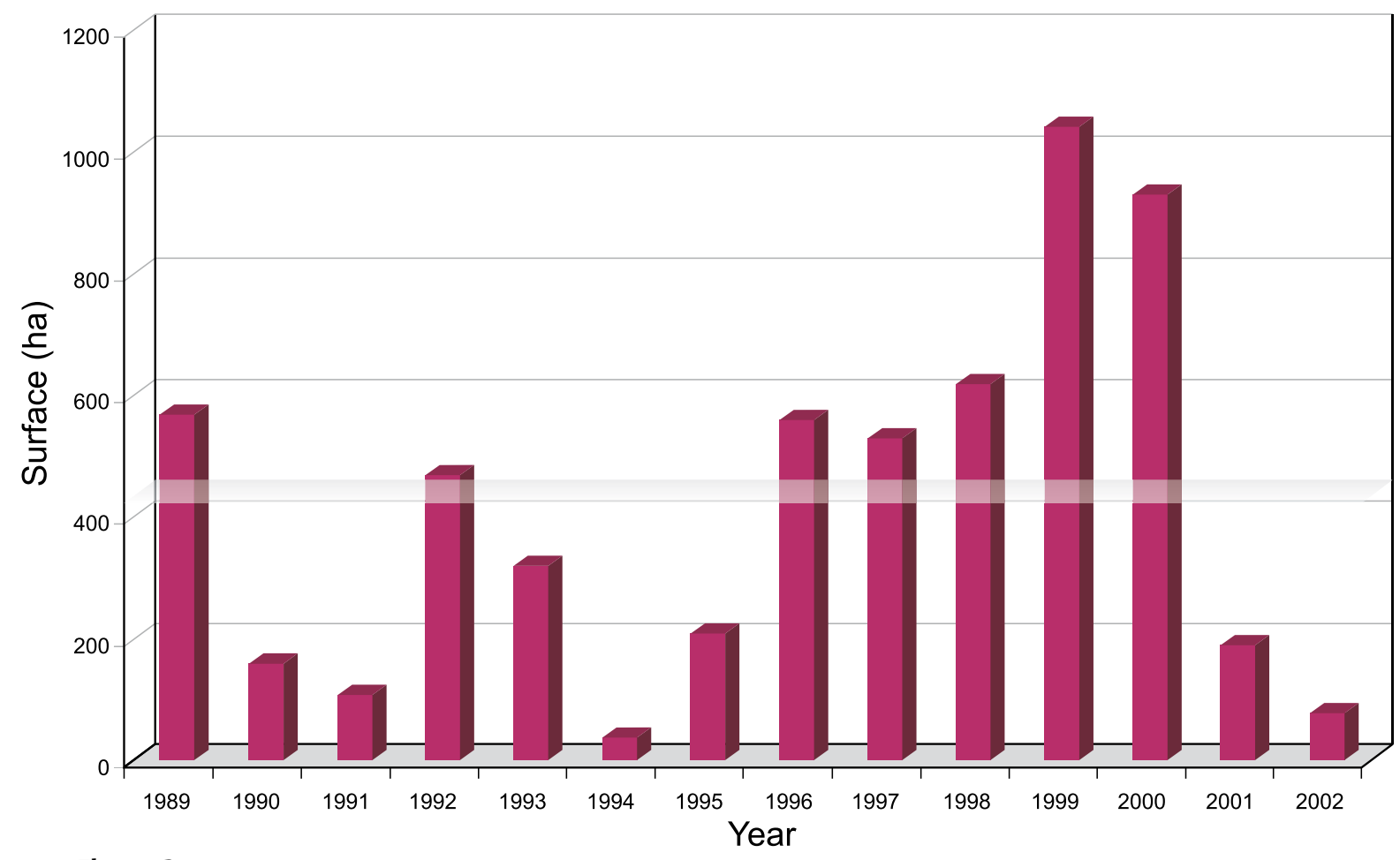

Figure 3 
forums were organised at the community, district and provincial levels, including annual meetings with all villages in the Malinau watershed to which government officials were invited and a community/government dialogue was held. The project supported visits by government officials to village activities and by villagers to meet district officials. The project monitored conditions at the village level from 2000-5, providing the information to both villagers and government officials. Government officials articulated what they thought should be the principles of good governance (cf. Lebel et al., 2006's discussion of the link between good governance and adaptive management).

The district government and communities never fully developed the leadership or institutional capacity to carry out these activities independently. While the concepts of adaptive management and participation were attractive, they involved skills, information, coordination and resources that were often not available, especially in a newly formed district struggling with more immediate pressures in a chaotic policy environment. These factors may be ultimately the most important limits to implementing more dynamic forms of land-use planning (cf Prato, 2007; Wollenberg et al., 2007).

\section{Using system frameworks for understanding land use as a process and anticipating change: drivers of change and trade-offs}

Further to support adaptive capacities, researchers assisted people in Malinau to explore potential changes, trends and tradeoffs. One activity was a workshop to identify collectively the parameters of Malinau's landuse system and develop a shared vision for land use, using visioning tools (Wollenberg et al., 2000). The meeting included government officials, the private sector, community members and representatives of NGOs, universities and churches. The group identified the main drivers of change they experienced under decentralisation and their hopes for the future, which included (1) increased income, (2) clear land use according to rights and land-use functions, (3) development of organisations that are efficient, coordinated and transparent, and (4) environmental conservation.
Another approach we used was simulation modelling to project the Malinau landscape and economy for 20 years. The model was designed to stimulate debate about the future, rather than being a predictive tool (see Suwarno et al., this volume). The model could incorporate practical knowledge generated by different groups and allow people to discuss risks and wider concerns and motivations for different kinds of land use (e.g. cultural heritage, gravesites, conservation). Likely drivers of change were included in the model, making it possible to explore diverse scenarios and conduct policy experiments. The model was built together with the planners at district level, giving them a degree of ownership of the model. In one of the closing workshops for the project, district officials presented the results of different model scenarios to their colleagues. The model highlighted the trade-offs of different development trajectories. For example, a high investment scenario of plantation development brought major development outcomes for the district, but these came at the cost of biodiversity conservation and the likely marginalisation of the current land users (Suwarno et al., this volume).

\section{Multiple levels of analysis and intervention}

To make planning relevant to different interest groups and drivers of change, the project worked at the district, sub-district, watershed, village, household, individual and forest site levels. We were surprised at how little effort was made by the district or communities to understand patterns at the watershed or sub-district levels, compared to the village and district levels. Yet monitoring at these levels is essential to tracking the impacts of large-scale land-use initiatives, such as efforts to establish oil-palm or timber plantations.

One example of multi-scale analysis was work on village land-use plans as a complement to the district plans. Researchers worked in one village that wanted to conserve its forest and another that wanted to manage its forest for timber. In each village CIFOR helped villagers to produce scenarios of their preferred village land uses, as well as supporting maps, inventories and management plans. Villages used multiple copies of a village map as a template to sketch 
in different configurations of land use for the purpose of discussing alternatives, documenting what existed or monitoring changes. A small committee in each village produced the first set of land-use plans and maps.

The conservation village used the maps to identify their core conservation area and different landuse zones. The other village designated areas for timber exploitation, protection and subsistence use. In both sites, we worked with the surrounding two to three villages to manage conflicts over land and create similar opportunities for landuse planning. In the conservation village, this resulted in the conservation forest being nearly doubled in area by a neighbouring village also allocating land for conservation.

We also promoted coordination of land use among villages at the sub-district level through annual meetings. To scale up the village efforts to district level, we invited land-use planners and government officials to participate in public village meetings and encouraged the district to communicate to the villagers what was feasible from the district's perspective. Villagers were encouraged to make presentations to district officials about their plans. The project lobbied the provincial and national authorities to recognise the community efforts, for which Setulang received a national environmental prize and was one of the finalists at the World Water Prize, and encouraged the international community to give a 'payment for environmental services' to reduce the land-use trade-offs between development and conservation (Wunder, 2007).

\section{Explicit activities and procedures to build capabilities}

Considerable attention went towards building capacity for spatial planning at the village and district level. Capacity building centred on providing technical information and enhancing communities' capacities to understand governmental policies and processes and to express their opinions and needs in the face of powerful district figures. Such capacity provided the basis for villagers, timber companies and district officials to engage in more informed discussion about future land use, development priorities, expectations and needs.
CIFOR developed communities' capacities to interpret recent policy reforms; read and make maps of different kinds; conduct forest inventories; map village resources; rank local values of resources and areas (Anau et al., 2001; Sheil and Liswanti, 2006); understand land-use options in other parts of Kalimantan (through cross-visits); conduct household surveys; make land-use plans; facilitate inter-village workshops and cross-site meetings; make proposals to appropriate local government officials; provide feedback to government officials on programme impacts; and negotiate and manage land-use conflict. Through cross-visits and contacts with different NGOs, the researchers linked villages to new networks. Villagers also used the opportunity to develop better shared understandings of rights and claims, as well as the needs and options for future land use. Government officials were sometimes invited to participate in these efforts.

At the district level, we worked with the district to set up a geographic information systems (GIS) laboratory in Malinau, and conducted four formal training courses, two funded by the project, one by local government budget, and one funded by a partnership agreement with other institutions (WWF Indonesia Programme and Tropenbos Indonesia Programme). When the research team initiated this work, we found six sophisticated new computers that had been stored for more than a year due to lack of skilled people to operate them.

Researchers also initiated the formation of the GIS Forum at the district level. The informal forum consisted of newly trained officers from different government sectors. Officers presented their work to the district government, including land erosion analysis, land suitability analysis and recalculation of land category designations.

The district government, including the local legislative body, was highly interested in the work and even acknowledged that the previous spatial plan, which they had gazetted and endorsed, included unrealistic allocations of land and needed to be updated. Oil-palm developments were being made without any prior impact assessments and despite evidence that they were technically unsuited for much of Malinau's landscape without intensive inputs. Malinau had many reasons for expanding its 
protection forests instead, based on its high biodiversity, status as a lowland forested area and its proximity to Kayan Mentarang National Park. Local officials concluded that they needed to formalise the forum, as well as evaluate and update the existing spatial plan.

We also worked with district officials to build their skills on systems modelling, including economic forecasting, and to enhance their capacities for monitoring community conditions and the impacts of government programmes.

Researchers shared the results of all studies back to communities and other local stakeholders to make the analysis available to them and deepen general understanding. Products took the form of hundreds of newsletters, 3,500 posters, 6,000 information rich cards and several hundred copies of videos. In addition, researchers collaborated with local government and WWF to develop an environmental education syllabus for Malinau's schools (Padmanaba and Sheil, 2007).

\section{DISCUSSION}

Malinau's spatial plan became little more than another report. Subsequent years showed its irrelevance to how government and local land users and managers made decisions.

To make planning more relevant in places like Malinau, we need to shift our thinking about planning 'away from planning as an instrument of control to one of innovation and action' (Friedmann (2003: 8), quoted in Byrne, 2003: 171): Byrne says we need to work with people in a participatory way to specify the range of possible futures and establish actions that will produce the futures people want. Landuse planning has a long way to go though before diverse stakeholders can play a role in the planning process in places like Malinau. Facilitation and intervention according to the five principles in this article can help.

CIFOR tried to approach land-use planning as an interactive and discretionary process. If land use is an ongoing activity, then planning must also create ongoing opportunities for creativity, design and adjustment. The approach emphasised finding ways to make local-level, practical knowledge and activities accessible to and usable by district decision-makers and communities. In this way, a better balance could be reached between the more simplified schemes that decision-makers needed and the contingency and context-based information from different communities. Interactive planning required the creation of interfaces between groups of people as well as between these two types of approaches.

In terms of concrete outputs, the work resulted in GIS layers that could be used by district planners and iteratively produced maps that could be used by villagers. This was a big step forward from previous planning. More important than the tangible outputs were the district's improved capacities to deal with change, the improved communication among stakeholders, and the reduced levels of conflict among villages and between villages and district officials.

The work showed that different aspects of a landuse plan demanded different degrees of flexibility (Wollenberg et al., 2007). Meeting community needs for forest, swidden and fallows required flexibility to respond to:

- Variation in natural resource availability over time as an influence on local land-use practices.

- The need to meet local needs for clear claims to resources, while acknowledging related fluctuating social networks and their needs for flexibility of access and benefit sharing.

In contrast, different groups' priorities for species and area protection required elements that constrained discretionary decision-making.

Conflictsamongthesedifferentaims are inevitable and require transparent, legitimate political processes to resolve them. In places such as Malinau, creating territorial boundaries without complementary acknowledgement of people's rights across boundaries may not be consistent with villagers' needs flexibly to use and make claims on the landscape. Nevertheless villagers themselves want firm and formal boundaries for acknowledgement of compensation claims. These sorts of conflicting needs and seemingly irresolvable tensions suggest that the need for flexibility in land-use planning is much higher than most people assume even at the local level. 
As a research organisation, we found it easiest to generate information, models, maps and GIS layers and to provide training. Coordinating workshops among groups and making information accessible to different groups at the right time was more challenging, in part because of the transitional nature of this period and poor capacity for coordination in the district.

Working outside the formal planning process provided more flexibility and impact than earlier efforts to work directly with the district's existing planning process. Predictably, the development of tools, methods and capacitybuilding efforts were more welcome than efforts to influence directly the land-use plan. Working with scenarios through GIS and systems models seemed to be well accepted because this offered information rather than advice.

At the village level, the impacts were less tangible, although we found that people referred to the new knowledge in discussions, and new relationships and networks were forged.

The kind of planning we are advocating is not inexpensive. Interactive planning should be most appropriate in places of high resource value and threat, where the stakes are high. Conventional plans can still play a role, provided they are more adaptive, participatory and set in larger governance frameworks. Interactive planning may benefit from external facilitation, as dynamic contexts can often make it difficult for planners and manager to invest in the necessary transactions costs of participation and information. People quickly see, however, that the benefits are worth it.

\section{ACKNOWLEDGEMENTS}

The research was supported by the International Tropical Timber Organization (IITO), the Department for International Development (DFID) UK, the Ford Foundation, the District of Malinau and the Netherlands Committee of the IUCN.

\section{REFERENCES}

Anau, N., Iwan, R., van Heist, M., Limberg, G., Sudana, M. and Wollenberg, E. 2002. Negotiating more than boundaries: conflict, power, and agreement building in the demarcation of village borders in Malinau'. Pp. 131-56 in CIFOR. ITTO project PD 12/97 Rev. $1(F)$ : forest, science and sustainability: the Bulungan model forest: technical report phase 1, 1997-2001. CIFOR, Bogor, Indonesia.

Anau, N., Iwan, R., van Heist, M., Limberg, G., Sudana, M., and Wollenberg, E. 2001. Pemetaan Desa Partisipatif dan Penyelesaian Konflik Batas: Studi Kasus Desa-Desa Daerah Aliran Sungai Malinau, Januari s/d Juli 2000. CIFOR, Bogor, Indonesia.

Andrianto, A. 2006. The role of district government in poverty alleviation: case studies in Malinau and West Kutai districts, East Kalimantan, Indonesia. CIFOR, Bogor, Indonesia.

Auricht, C. M. and Rais, J. 2000. Spatial development planning in Indonesia. Report, Land Administration Project part C. National Development Planning Agency and National Land Agency, Government of Indonesia. Jakarta.

Basuki, I. and Sheil, D. 2005. Local perspectives of forest landscapes: A preliminary evaluation of land and soils, and their importance in Malinau, East Kalimantan, Indonesia. CIFOR, Bogor, Indonesia.

Byrne, D. 2003. 'Complexity theory and planning theory: a necessary encounter'. Planning Theory 2(3): pp. 171-8.

Campbell, B.M., Sayer, J., Cowling, R., Kassa, H., Knight, A., Sandker, M. and Suwarno, A. (in press). The role of participating modelling in landscape approaches to reconciling conservation and development. Ecology and Society.

Cunliffe, R., Lynam, T., Sheil, D., Wan, M., Salim, A., Basuki, I. and Priyadi, H. [in press]. 'Developing a predictive understanding of landscape importance to the Punan-Pelancau of East Kalimantan, Borneo'.

Dounias, E. and Loutrel, G. 2002. Swidden fallows among the Punan of upper Tubu river (East-Kalimantan) What do they tell us about agroecosystem dynamics? Oral presentation at the Borneo Research Council Conference. Kota Kinabalu: 15-18 July 2002. 
Forester, J. 1989. Planning in the face of power. University of California Press, Berkeley, USA.

Friedmann, J. 2003. Why do planning theory? Planning Theory 2(1): pp. 7-10.

Haddock, M. 1999. Guide to forest land use planning. West Coast Environmental Law Association, Vancouver, Canada.

Lebel, L., Anderies, J. M., Campbell, B., Folke, C., Hatfield-Dodds, S., Hughes, T.P. and Wilson, J. 2006. 'Governance and the Capacity to Manage Resilience in Regional SocialEcological Systems'. Ecology and Society 11(1): p.19. [online] URL: http://www. ecologyandsociety.org/vol11/iss 1/art19/

Lloyd, M.G. and Peel, D. 2007. 'Shaping and designing model policies for land use planning'. Land Use Policy 24: pp. 154-64.

Lusiana, B., van Noordwijk, M. and Rahayu, S. editors. 2005. Carbon stocks in Nunukan, East Kalimantan: a spatial monitoring and modelling approach: report from the carbon monitoring team of the Forest Resources Management for Carbon Sequestration (FORMACS) project. World Agroforestry Centre - ICRAF, Bogor, Indonesia.

Lynam, T., Cunliffe, R., Sheil, D., Salim, A., Basuki, I., Priyadi, H. and Wan, M. [in press] 'Tropical forest landscapes and the local importance of ecosystem goods and services: developing a predictive understanding in East Kalimantan'.

Meijaard, E. and Nijman, V. 2003. 'Primate hotspots on Borneo: predictive value for general biodiversity and the effects of taxonomy'. Conservation Biology 17: pp. 725-32.

Meijaard, E., Sheil, D., Nasi, R., Augeri, D., Rosenbaum, B., Iskandar, D., Setyawati, T., Lammertink, A., Rachmatika, I., Wong, A., Soehartono, T., Stanley, S. and O'Brien, T. 2005. Life after logging: reconciling wildlife conservation and production forestry in Indonesian Borneo. CIFOR, Bogor, Indonesia.

Mintzberg, H. 1993. The rise and fall of strategic planning. The Free Press, New York, USA.

Padmanaba, M. and Sheil, D. 2007. 'Finding and promoting a local conservation consensus in a globally important tropical forest landscape'. Biodiversity and Conservation. 16: pp. 137-51.
Prato, T. 2007. 'Evaluating land use plans under uncertainty'. Land Use Policy 24: pp. 16574.

Rose, C. M. 1994. Property and persuasion: essays on the history, theory and rhetoric of ownership. Westview Press, Boulder, CO, USA.

Sayer, J. and Campbell, B. 2004. The science of sustainable development: local livelihoods and the global environment. Cambridge University Press, Cambridge, UK.

Scott, J. 1998. Seeing like a state. Yale University Press, New Haven, USA.

Sellato, B. 2001. Forest, resources and people in Bulungan: elements for a history of settlement, trade and social dynamics in Borneo, 18802000. CIFOR, Bogor, Indonesia.

Sheil, D. and Liswanti, N. 2006. 'Scoring the importance of tropical forest landscapes with local people: patterns and insight'. Environmental Management 38: pp. 12636.

Sheil, D., Puri, R., Wan, M., Basuki, I., van Heist, M., Liswanti, N. Rukmiyati, Rachmatika, I. and Samsoedin, I. 2006. 'Local people's priorities for biodiversity: examples from the forests of Indonesian Borneo'. Ambio 35: pp. $17-24$.

Stacey, R.D. 2003. Strategic management and organisational dynamics: the challenge of complexity. Fourth edition. Financial Times/ Pearson Education, England.

Theobald, D.M., Hobbs, N.T., Bearly, T., Zack, J., Shenk, T. and Riebsame, W.E. 2000. 'Incorporating biological information in local land use decision making: designing a system for conservation planning'. Landscape Ecology 15(1): pp. 35-45.

Wollenberg, E., Edmunds, D. and Buck, L. 2000. Anticipating change: scenarios as a tool for adaptive forest management. A guide. CIFOR. Bogor, Indonesia.

Wollenberg, E., Iwan, R., Limberg, G., Moeliono, M., Rhee, S. and Sudana, M. 2007. 'Facilitating cooperation during times of chaos: spontaneous orders and muddling through in Malinau District, Indonesia'. Ecology and Society 12(1): p. 3. [online] URL: http://www.ecologyandsociety.org/ vol12/iss 1/art3/

Wunder, S. 2007. 'The efficiency of Payments for Environmental Services in tropical conservation'. Conservation Biology. 21(1): pp. $48-58$. 


\section{CHAPTER 7 REDUCED IMPACT LOGGING: BENEFITS AND CONSTRAINTS}

Hari Priyadi, Plinio Sist, Petrus Gunarso, Markku Kanninen, Kuswata Kartawinata, Douglas Sheil, Titiek Setyawati, Hariyatno Dwiprabowo, Hadi Siswoyo,

Gerald Silooy, Chairil Anwar Siregar and Wayan Susi Dharmawan 


\section{INTRODUCTION}

Any efforts at achieving sustainable management of mixed dipterocarp forest are fraught with disincentives due to the lucrative short-term gains from destructive, and often illegal, timber extraction. Logging in the tropics, as conventionally practised, depletes timber stocks and causes severe ecological damage to residual forests. In general, conventional forest logging may cause detectable changes in environmental variables, depending on the intensity of disturbance and the extent of forest cover removed. By the same token, forest clearance and forest conversion to other land uses cause greater impacts on hydrology and soil-erosion processes. With the progress towards sustainable forest management, improved harvesting techniques known as Reduced Impact Logging (RIL) are being implemented and promoted in various regions. The aim of RIL is to reduce damage to residual trees, limit soil disturbance and impacts on wildlife by reducing the adverse consequences of skidding and road building, and introduce directional felling and climber cutting prior to felling (Sist et al., 1998, 2003; Elias et al., 2001; see also Sheil and Meijaard, this volume). In essence, the damage to the residual forest is lessened by implementing these techniques, allowing the forest to recover more quickly from logging operations.

RIL techniques have been integrated within a longer-term research strategy to develop sustainable forest-management strategies for the Malinau Research Forest. This work was conducted in the Malinau concession of a local logging company, Inhutani II, with technical supervision undertaken by CIFOR. Research on the immediate and long-term impacts of timber harvesting from both environmental and economic perspectives was carried out, comparing both conventional and RIL logging techniques. The overall objective was to demonstrate the environmental and economic benefit of RIL to promote its integration into logging operations at the concession scale. A summary of the forest structure and diversity prior to logging activities is presented in this chapter. Based on analysis of data collected from permanent sample plots, the impacts and benefits of RIL on harvested areas and volume, periodic annual diameter increment, as well as damage to the residual stand and the effects on soil and erosion, are compared to conventional logging. The fundamental problems and barriers to the adoption of RIL by logging companies are also discussed.

\section{THE CURRENT PROBLEM}

The Indonesian selective logging and planting system (called TPTI: Tebang Pilih Tanam Indonesia) is the currently accepted silvicultural system in Indonesia. It stipulates that all dipterocarps (i.e timber trees in family Dipterocarpaceae) with a diameter of $>50 \mathrm{~cm}$ dbh (diameter at breast height) can be harvested with a polycyclic felling rotation of 35 years. As such, the harvesting intensity in Indonesian dipterocarp forest exceeds $100 \mathrm{~m}^{3} / \mathrm{ha}$, or more than 10 trees/ha. Unfortunately, conventional logging generally damages more than $50 \%$ of the original stand. Several experiments in mixed dipterocarp forest have demonstrated that RIL techniques can reduce damage by at least 30$50 \%$ compared with conventional logging and can probably shorten the logging cycle due to better post-harvest regeneration (Putz, 1994).

At present, the common belief among loggers is that RIL techniques cost more to implement, in simple economic terms, than conventional timber-harvesting operations and this is certainly deterring the adoption of RIL by many companies, including those operating in Malinau.

However, the few existing comparative studies on economic cost assessments carried out in Amazonia show this is not necessarily the case. Studies by Barreto et al. (1998) and Holmes et al. (1999) demonstrate that, when compared with conventional logging techniques, the costs of implementing a programme of RIL increased in the planning stage. However, proper and systematic planning led to increased labour productivity, decreased operational costs and reduced waste, leading to RIL costing an estimated $12 \%$ less than conventional logging (Holmes et al., 1999). 


\section{APPROACH AND METHODS}

\section{Study site}

The study area is located in the Indonesian Province of East Kalimantan, on the island of Borneo, within a 50,000 ha forest concession managed by Inhutani II, a state-owned logging company. The topography is steep with elevations ranging from 200 to $600 \mathrm{~m}$ above sea level (see Gunarso [this volume] for a more comprehensive site description).

\section{Permanent sample plots and treatments}

Three experimental blocks (27, 28 and 29) of about 100 ha each were selected in the 19989 annual coupe because of their similarity in topography and the presence of Agathis borneensis, a highly valuable timber species, which occurs at a similar relative density in these blocks (3 to 4 trees/ha). Because both blocks 28 and 29 comprised about $50 \%$ of swamp forest unsuitable for logging, they were merged to have a productive forest area similar to that of block 27. Blocks 28/29 were logged conventionally
(CL) in 1998 and block 27 using RIL techniques in 1999. In conventional logging, harvesting operations were not planned and the loggers worked without supervision. In the RIL block, all the operators were trained to apply the RIL technical guidelines as published in Sist et al. (1998). As a component of RIL, the pre-harvesting inventory in block 27 led to the production of an operational map at 1:2,000 scale, showing 5 $\mathrm{m}$ contour lines and the position of harvestable timber trees. To help the tree fellers select the best felling direction, skid trails were opened prior to felling, following the skid trail network planned and drawn on the operational map.

Seven different treatments, each with three replicates and a control plot were established to take into account the felling intensity. Before logging, 24 1-hectare permanent sample plots (12 in 28/29 and 12 in 27), were selected randomly and treatment allocated according to the respective timber density in each plot. Each plot $(100 \times 100 \mathrm{~m})$ was divided into 25 sub-quadrats of $20 \mathrm{~m} \times 20 \mathrm{~m}$, delimited by 36 PVC stakes. Before logging, the girth of all trees and lianas with $\mathrm{dbh} \geq 20 \mathrm{~cm}$ in the plots were measured and their position located in the sub-quadrats. In the three control plots of the

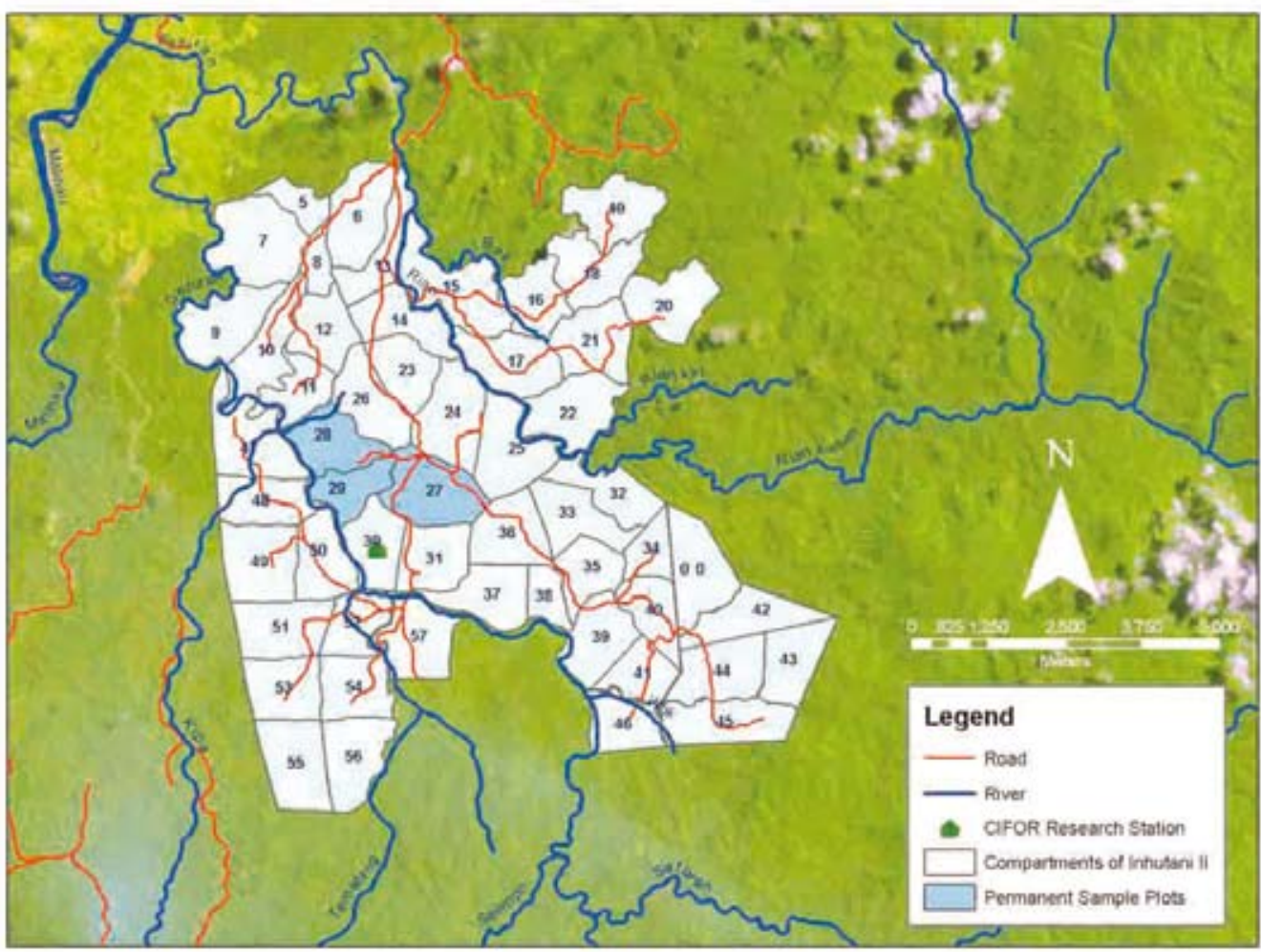

Figure 1. The blocks where permanent sample plots (PSPs) are located (arrow), blocks 28 and 29 for CL Plots and block 27 for RIL plots (including control plots) 
conventional logging blocks and the nine plots of RIL, canopy openness was measured using a concave spherical densiometer at each of the 36 grid points. Canopy openness is defined as the proportion of sky hemisphere not obscured by the vegetation when viewed from a single point (Jennings et al., 1999).

In both conventional logging and RIL blocks, logging damage was assessed eight months after logging. In the plots, all trees (dbh $\geq 20$ $\mathrm{cm}$ ) measured prior to logging were recorded as untouched, injured or dead. Canopy openness was also reassessed in the 17 logged plots. In each block, all the skid-trails were mapped and classified as main or secondary. The total volume extracted in each block was measured to compare their respective skid trail area per timber volume extracted. Along each skid trail, at every $50 \mathrm{~m}$, the width and depth of the track was measured.

Regeneration studies were carried out in four permanent sample plots (PSPs) each in both the conventional logging and the RIL blocks representing low-, medium- and high-intensity logged plots. A systematic sampling approach was implemented in the eight PSPs established in both conventional logging and RIL blocks, including those plots that were not harvested (undisturbed) as control plots. The regeneration study was undertaken in PSPs which consist of two subplots of $100 \mathrm{~m}^{2}(20 \mathrm{~m} \times 5 \mathrm{~m})$ in each 1ha plot, translating into $10 \%$ sampling intensity. Re-measurement of the PSPs was undertaken in 2004, a third such enumeration.

\section{Annual diameter growth increment}

Growth was measured based on periodic annual diameter increment $(\mathrm{Pd})$. In this study, the data used were based on measurement from 1998 to 2004. Pd was calculated using the following equation (1):

$\mathrm{P}_{\mathrm{d}}=\frac{d_{t+k}-d_{t}}{k} \times 365$

Where

$\mathrm{Pd}=$ observed periodic annual diameter increment $\left(\mathrm{cm}\right.$ year $\left.{ }^{1}\right)$ $d_{t+k}=$ diameter at end of growth period $(\mathrm{cm})$ $\mathrm{d}_{\mathrm{t}}=$ diameter at beginning of

growth period $(\mathrm{cm})$

$\mathrm{k}$ = length of growth period (days)

\section{Logging damage assessment}

Logging damage was assessed following three different but complementary approaches:

\section{Damage to trees $\geq 20 \mathrm{~cm} \mathrm{dbh}$}

All trees recorded in the PSP prior to logging were checked and the type of injuries or causes of mortality recorded and coded according to the classification described below. Logging damage was assessed in terms of proportion of the original tree density or basal area of trees killed or injured by logging.

\section{Mapping of skid-trail and canopy opening}

In the PSPs, the projection of canopy openings were mapped and classified according to the following groups:

Code 1: Closed canopy, undisturbed

Code 2: Closed canopy with a skid-trail beneath (i.e understorey vegetation destroyed)

Code 3: Interrupted canopy in a felling area (understorey vegetation still present)

Code 4: Interrupted canopy in a skid-trail area (understorey vegetation destroyed)

Code 5: Open canopy in a felling area

Code 6: Open canopy in a skid-trail area

Code 7: Open canopy, natural gap

\section{Canopy closure}

In both permanent sample plots and along skid-trails, canopy closure was measured with a densiometer. Measurements were made at each of the 36 grid points in the plots and along the skid-trails every $50 \mathrm{~m}$. At each point, four readings were made: one at north, south, east and west. This study aimed to quantify canopy opening after logging and to check the validity of the first rapid assessment of canopy opening based on the seven codes cited above.

\section{Soil survey}

The soil survey was undertaken in both conventionally logged and RIL blocks, 
Table 1. Code of classification for types of injuries and causes of mortality

\begin{tabular}{lll}
\hline Code & Description & Observations \\
\hline Smashed Trees (SM) & & \\
\hline SM1 & Smashed trees at height $<3 \mathrm{~m}$ & Dead \\
\hline SM2 & Smashed trees at height $>3 \mathrm{~m}$ & Dead \\
\hline SM3 & Smashed trees at height $>3 \mathrm{~m}$ with still few branches & \\
\hline Crown Damage(CD) & & \\
\hline CD 1 & Minor crown damage, only small branches broken & Alive \\
\hline CD2 & Medium crown damage, medium-size branches broken & Alive \\
\hline CD3 & Sever crown damage, at least half crown destroyed & Alive \\
\hline Leaning Trees (LT) & & \\
\hline LT1 & Leaning angle $<20^{\circ}$ & Alive \\
\hline LT2 & Leaning angle 20-45 & Alive \\
\hline LT3 & Leaning angle $>45^{\circ}$ & Alive or dead \\
\hline Bark and wood (BW) & & \\
\hline BW 1 & Minor, only small part of bark removed & Alive \\
\hline BW2 & Medium, bark and sapwood affected & Alive \\
\hline BW3 & Major, bark and sapwood affected on a large part of the bole & Alive or dead \\
\hline Uprooted Trees (UT) & & Dead \\
\hline
\end{tabular}

implemented in 1998 and 1999 respectively. Two erosion plots of $22 \mathrm{~m} \times 4 \mathrm{~m}$ were established. The parameters measured were soil erosion, run-off water, soil bulk density $(\mathrm{BD})$ and soil chemical properties (Potassium (K) and Phosphorous (P)). Soil samples were collected systematically in the area adjacent to the erosion plot.

Five further soil-sampling points were established with sampling points of $50 \mathrm{~cm}$ in depth. By using volume cylinders (soil sampler), a known amount of soil was taken at each sampling. In the case of $10 \mathrm{~cm}$ depths, four ring samplers of soil were taken in $0-5 \mathrm{~cm}$ layer and the other four ring samplers were taken in $5-10 \mathrm{~cm}$ layer in order to have greater precision in the results of soil BD. Meanwhile in $20 \mathrm{~cm}$ sampling depths, two ring samplers of soil were taken in 10-15 $\mathrm{cm}$ layer and the others were taken in $15-20 \mathrm{~cm}$ layer. The soil- sampling procedure in $20-50 \mathrm{~cm}$ sampling depth was the same as that of $20 \mathrm{~cm}$ sampling depth. Soil samples collected using the ring soil sampler were kept for analysis of the soil bulk density, soil texture, soil $\mathrm{pH}$, soil organic matter, as well as $\mathrm{P}$ and $\mathrm{K}$. Representative soil profiles were then prepared for the conventional logging and RIL treatments.

\section{Adoption study}

CIFOR and the Tropical Forest Foundation (TFF) have jointly conducted an 'adoption study' regarding the possible uptake of RIL techniques with 18 concession holders in East Kalimantan, Central Kalimantan and West Kalimantan. PT Inhutani II in Malinau and PT Intraca Wood in Tarakan are among other companies which have been surveyed in East Kalimantan. The objectives were to know how far RIL is implemented in the selected companies, to assess each manager's perception in implementing RIL and analyse the internal and external factors that influence RIL's implementation. Questionnaires were sent to company owners (located mostly in Jakarta), camp managers and operators (in the field).

\section{RESULTS}

\section{Forest structure and species richness}

A total of 705 tree species were recorded from the permanent sample plots, of which 67 (9.5\%) were species within the Dipterocarpaceae. 
Among the most relatively abundant species were Dipterocarpus lowii, D. stellatus, Shorea beccariana, S. brunescens, S. exelliptica, $S$. macroptera, S.maxwelliana, S. multiflora, $S$. parvifolia, S. rubra and S. venulosa. Altogether, 29 families were represented in the RIL block and CL block (Kartawinata et al., 2006). The largest families, which each contained more than 10 species and were common to both the RIL and CL (control) blocks, were Dipterocarpaceae, Euphorbiaceae, Myrtaceae, Lauraceae, Fagaceae, Myristicaceae, Sapotaceae, Clusiaceae, Fabaceae, Anacardiaceae, Ebenaceae, Moraceae and Burseraceae. The Dipterocarpaceae is the most important family in the study area.

Agathis borneensis, in the family Araucariaceae, is one of the most significant timber species in the study area. This tree has a very high value on the timber market and is therefore highly appreciated by loggers. The bole generally shows no defect in shape and buttresses are absent. It is worth noting that Agathis spp has the second largest basal area after dipterocarps compared with non-dipterocarps in the size classes above $80 \mathrm{~cm} \mathrm{dbh}$. The species is not homogeneously distributed but occurs on the tops or edges of ridges on well-drained soils.

Trees with dbh of $>50 \mathrm{~cm}$ (commercially harvestable trees) constituted $46.2 \%$ in the
RIL block and $50.3 \%$ in the CL block. Trees with $\mathrm{dbh}>60 \mathrm{~cm}$ were dominated by species Dipterocarpus and Shorea species but nondipterocarp species, such as Agathis borneensis and Koompassia malaccensis, are also abundant (Figure 2). Species of the Dipterocarpaceae family were dominant, contributing about $27 \%$ of the total tree density and $40 \%$ of the basal area (BA). They also form the main component of the canopy trees. The largest tree so far recorded was Shorea venulosa with a dbh of $199.6 \mathrm{~cm}$.

\section{Harvested areas and volume}

Overall, the mean diameters of measured trees in conventionally logged (CL) and RIL blocks were significantly different $(C L \quad X=92 \mathrm{~cm}$ vs $82 \mathrm{~cm}$, $t=7.08, d f=799, P<0.01)$. The mean diameters of harvested logs of Agathis were similar in $\mathrm{CL}$ and RIL blocks ( $X=96 \mathrm{~cm}$ vs $93 \mathrm{~cm}, \mathrm{t}=1.42, \mathrm{df}=366$, $\mathrm{P}=0.16)$. In contrast, logs of dipterocarps were larger in the conventional blocks than in RIL (CL: $88 \mathrm{~cm}$ vs $73 \mathrm{~cm}, \mathrm{df}=374, \mathrm{t}=10.17, \mathrm{P}<0.01$ ). These measurements resulted in the fact that the average extracted volume in the conventional blocks was higher than in the RIL compartment $\left(10.5 \mathrm{~m}^{3}\right.$ vs $\left.9.0 \mathrm{~m}^{3}, \mathrm{t}=3.76, \mathrm{df}=708, \mathrm{P}<0.01\right)$. The number of extracted trees in the harvested area showed a difference of only one tree per ha between conventional and reduced-impact logging (6 trees/ha and 7 trees/ha, respectively).

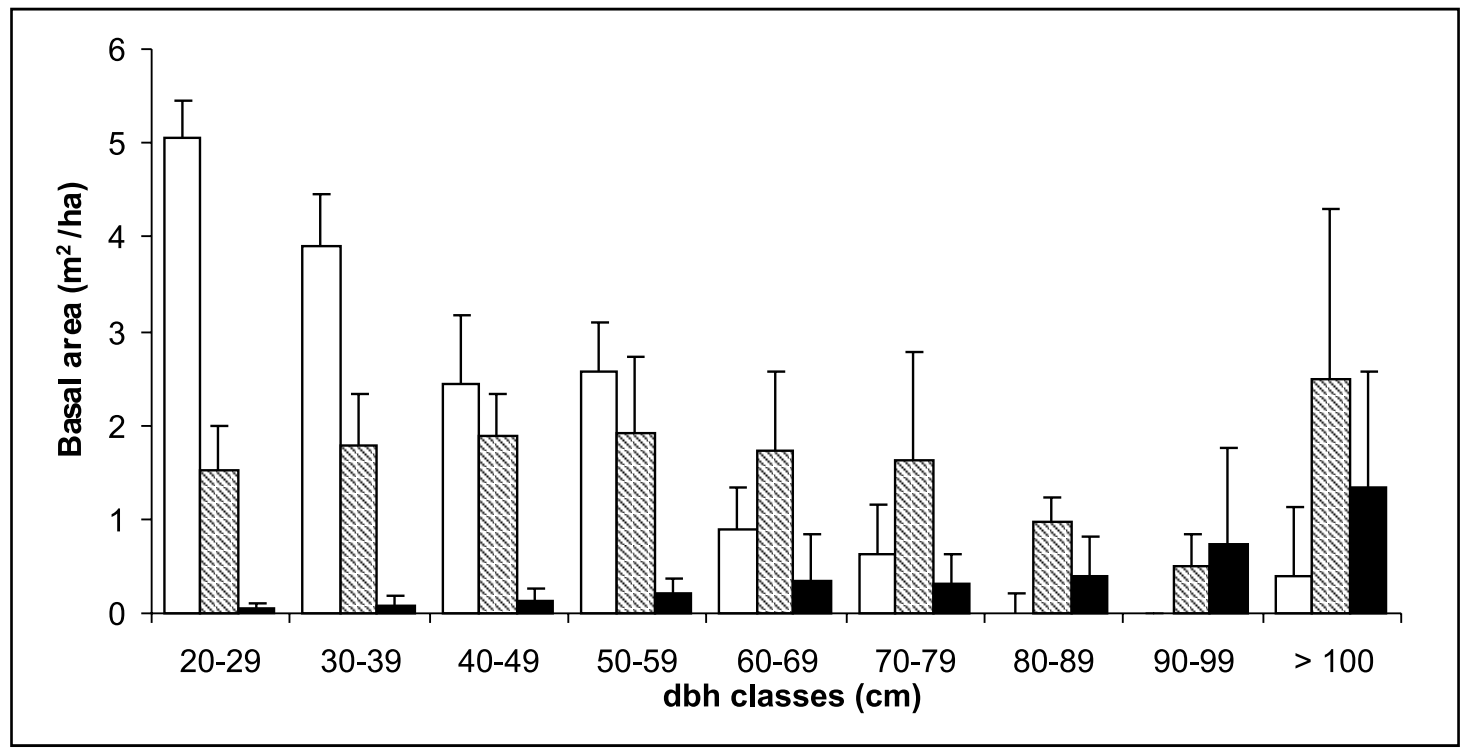

Figure 2. Basal areas of non dipterocarps (left bar), dipterocarps (middle bar) and Agathis borneensis (right bar) in the seven plots of block 28/29 where this species was present before logging 
Table 2. Mean density and mean basal areas $( \pm S D)$ in the RIL and CL plots before logging $(C L=12$ plots, RIL $=12$ plots)

\begin{tabular}{lcccccc}
\hline \multicolumn{7}{c}{ dbh (cm) } \\
\hline $\begin{array}{l}\text { RIL plots density } \\
\text { (n/ha) }\end{array}$ & $\mathbf{2 0 - 2 9}$ & $\mathbf{3 0 - 3 9}$ & $\mathbf{4 0 - 4 9}$ & $\mathbf{5 0 - 5 9}$ & $\mathbf{2 6 0}$ & All \\
\hline $\begin{array}{l}\text { CL Plots density } \\
\text { (n/ha) }\end{array}$ & $124.3 \pm 31.2$ & $52.5 \pm 12.9$ & $26.3 \pm 7.0$ & $14.9 \pm 5.6$ & $22.4 \pm 6.2$ & $239.8 \pm 53.7$ \\
\hline $\begin{array}{l}\text { Mean density RIL }+\mathrm{CL} \\
\text { (n/ha) }\end{array}$ & $128.6 \pm 24.7$ & $54.3 \pm 9.6$ & $27.2 \pm 5.8$ & $15.3 \pm 5.4$ & $23.0 \pm 5.3$ & $248.8 \pm 34.1$ \\
\hline $\begin{array}{l}\text { RIL Plots basal area } \\
\left(\mathrm{m}^{2} / \mathrm{ha}\right)\end{array}$ & $6.3 \pm 1.0$ & $5.0 \pm 0.9$ & $4.4 \pm 0.9$ & $3.3 \pm 1.4$ & $10.5 \pm 2.5$ & $29.6 \pm 3.8$ \\
\hline $\begin{array}{l}\text { CL Plots basal area } \\
\left(\mathrm{m}^{2} / \mathrm{ha}\right)\end{array}$ & $5.7 \pm 1.2$ & $5.2 \pm 0.8$ & $4.1 \pm 0.9$ & $3.6 \pm 1.1$ & $13.8 \pm 4.1$ & $32.4 \pm 5.1$ \\
\hline $\begin{array}{l}\text { Mean Basal area } \\
\left(\mathrm{m}^{2} / \mathrm{ha}\right)\end{array}$ & $5.9 \pm 1.1$ & $5.1 \pm 0.9$ & $4.3 \pm 0.9$ & $3.5 \pm 1.2$ & $12.2 \pm 3.7$ & $31.2 \pm 4.7$ \\
\hline
\end{tabular}

\section{Felling and skidding}

Felling and skidding are two interdependent activities. In the Malinau concession, RIL increased felling and skidding productivity by $28 \%$ and $25 \%$ respectively in comparison with CL. Directional felling in RIL was primarily intended to facilitate skidding in order to avoid residual stand damage. Further improved practice in felling might improve skidding productivity further, although it might reduce a feller's productivity. The benefits of directional felling were clearly seen in Malinau. For example, with regard to waste reduction, the volume of logs falling into ravines in the RIL blocks was lower than in CL i.e $4.20 \mathrm{~m}^{3}(1 \mathrm{log})$ vs $49.4 \mathrm{~m}^{3}(5 \mathrm{logs})$. These accounted for $6.4 \%$ of the total logs left in RIL and $8.5 \%$ in CL or $0.12 \%$ of total extracted volume in RIL and $0.9 \%$ in CL respectively.
The costs of skidding were also reduced by $27 \%$ in RIL. In the Brazilian Amazon, Holmes et al. (1999) reported that RIL increased skidding productivity by $41 \%$ in comparison with $\mathrm{CL}$ while felling and bucking decreased by $20 \%$. Hout (1999) also reported reduced felling performance by $37 \%$ in RIL while skidding output increased from $14.4 \mathrm{~m}^{3} / \mathrm{h}$ to $15.9 \mathrm{~m}^{3} / \mathrm{h}$. The RIL study in West Kalimantan reported an increase of a feller's daily productivity by $24 \%$ and skidding productivity by $14 \%$ in terms of the number of felled trees and extracted logs (NRM Project, 1994). In another RIL study in the Inhutani I concession in Berau, East Kalimantan, RIL increased the skidding hourly productivity from $7.8 \mathrm{~m}^{3}$ to $11.7 \mathrm{~m}^{3}$ or $50 \%$ in comparison with $\mathrm{CL}$ (Natadiwirya, pers. comm). RIL in the Berau study showed a decrease in the skidding cost by $50 \%$ in comparison with $\mathrm{CL}$. The unit

Table 3. Characteristics of extracted timber volume and density in conventionally logged (CL) and Reduced-Impact Logging (RIL)

\begin{tabular}{lcc}
\hline Characteristics & CL & RIL \\
\hline Total area (ha) & 244 & 138 \\
Extracted volume per ha based on total area $\left(\mathrm{m}^{3} / \mathrm{ha}\right)$ & 19.7 & 24.7 \\
Harvested area (ha; \%) & $91 ; 37$ & $56 ; 41$ \\
Extracted volume based on harvested area $\left(\mathrm{m}^{3} / \mathrm{ha}\right)$ & 52.8 & 60.9 \\
Total no. of felled trees & 536 & 386 \\
No. of felled trees on harvested area per ha & 5.9 & 6.9 \\
Average extracted volume per tree $\left(\mathrm{m}^{3}\right)$ & 10.3 & 9.0 \\
\hline
\end{tabular}




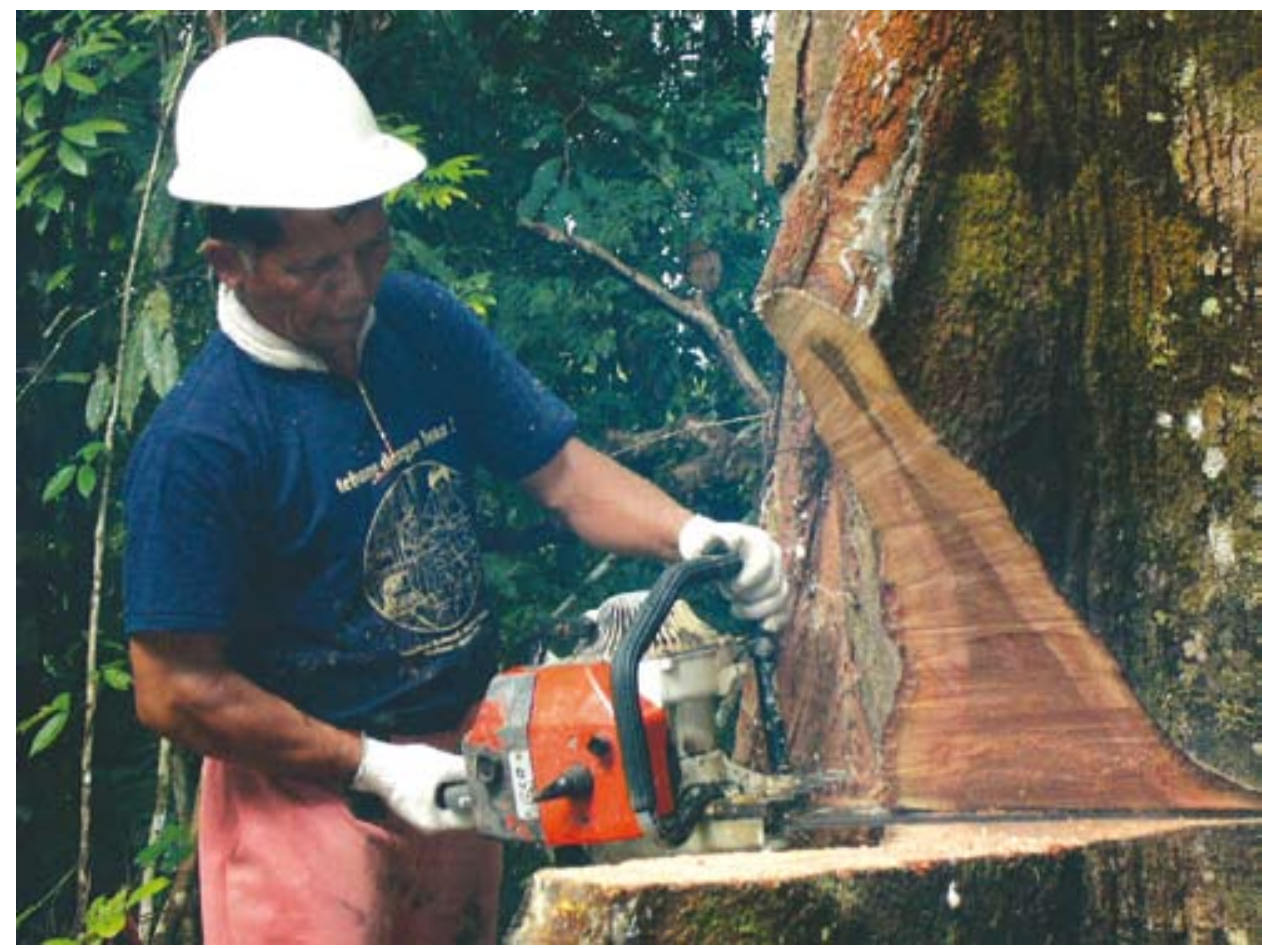

Directional felling should be well implemented in RIL techniques (Photo by Hari Priyadi)

cost of skidding both in CL and RIL in Malinau was lower than that in Berau due to greater productivity (Dwiprabowo et al., 2002).

\section{Periodic Annual Diameter Increment}

From the last of measurements (2004) the periodic annual diameter increment of the stand for dipterocarps in CL plots was $0.50 \mathrm{~cm}_{\text {year }}{ }^{-1}$ $(\mathrm{SD}=0.1693)$, while in non-dipterocarps this was $0.33 \mathrm{~cm}$ year ${ }^{-1}(\mathrm{SD}=0.0916)$. Within the RIL plots, the diameter increment of dipterocarps was $0.41 \mathrm{~cm}$ year $^{-1}(\mathrm{SD}=0.0877)$, while nondipterocarps was lower, amounting to $0.33 \mathrm{~cm}$ year $^{-1}(\mathrm{SD}=0.0803)$. The tables below explain that the periodic annual diameter increment for dipterocarps in $\mathrm{CL}$ plots by using low and medium felling intensities is 0.62 and 0.47 $\mathrm{cm}$ year ${ }^{1}$ respectively. Those increments were higher compared with RIL plots for the same group of species and felling intensity $(0.35 \mathrm{~cm}$ year $^{-1}$ and $0.37 \mathrm{~cm}_{\text {year }}{ }^{-1}$. The same situation also applied in the non-dipterocarp group. In contrast, in the RIL plots in which high felling intensity occurred, the diameter increment is higher compared with $\mathrm{CL}$ (0.52 and 0.38
Table 4. The periodic annual diameter increment in the Plots of RIL

\begin{tabular}{lcc}
\hline \multirow{2}{*}{$\begin{array}{l}\text { Logging } \\
\text { Intensity }\end{array}$} & \multicolumn{2}{c}{ Plot's of RIL } \\
\cline { 2 - 3 } & $\begin{array}{c}\text { Dipterocarps } \\
\text { (cm year-1) }\end{array}$ & $\begin{array}{c}\text { Non- } \\
\text { Dipterocarps } \\
\text { (cm year-1) }\end{array}$ \\
\hline Low Intensity & 0.35 & 0.24 \\
\hline Medium Intensity & 0.37 & 0.36 \\
\hline High Intensity & 0.52 & 0.38 \\
\hline
\end{tabular}

Table 5. The periodic annual diameter increment in the Plots of $\mathrm{CL}$

\begin{tabular}{lcc}
\hline & \multicolumn{2}{c}{ Plots of CL } \\
\cline { 2 - 3 } $\begin{array}{l}\text { Logging } \\
\text { Intensity }\end{array}$ & $\begin{array}{c}\text { Non- } \\
\text { Dipterocarps } \\
(\mathbf{c m} \text { year-1) }\end{array}$ & $\begin{array}{c}\text { Dipterocarps } \\
\left.\text { (cm year }{ }^{-1}\right)\end{array}$ \\
\hline Low Intensity & 0.62 & 0.33 \\
\hline Medium Intensity & 0.47 & 0.39 \\
\hline High Intensity & 0.42 & 0.28 \\
\hline
\end{tabular}


versus 0.42 and $0.28 \mathrm{~cm}_{\text {year }}{ }^{-1}$. Logging had a stimulating effect on growth as a consequence of the canopy opening and sudden light inflow to the understorey. Those species that took the most advantage of this situation and reacted most vigorously were also those that suffered most from competition before logging. This is consistent with initial studies in which the average of canopy openness varies from $4 \%$ (low felling intensity) to $18 \%$ (high felling intensity).

The correlation between periodic annual diameter increment $(\mathrm{y})$ and felling intensity $\left(\mathrm{F}_{\mathrm{P}}\right)$ expressed in the following regression equation:

$\operatorname{Dipt}_{R / L}=0.242+0.0850 F_{1}\left(R^{2}=70.4 \%\right)$

Non-Dipt ${ }_{R I L}=0.190+0.0683 F_{I}\left(R^{2}=54.3 \%\right)$

Dipt $_{C L}=0.704-0.0985 F_{l}\left(R^{2}=27.4 \%\right)$

Non-Dipt $C_{C L}=0.370-0.0200 F_{I}\left(R^{2=3.9 \%}\right)$

Where:

$\mathrm{Y}=$ periodic annual diameter increment for dipterocarps or non-dipterocarps

$\mathrm{F}_{1}=$ Felling intensity

Using the equation above, RIL plots exhibit positive correlations between periodic annual diameter increment and felling intensity, both for dipterocarp and non-dipterocarp species $\left(P_{\text {value }}=0.005\right.$ and $P_{\text {value }}=0.024$ respectively $)$. Meanwhile, the correlation between increment and felling intensity in $\mathrm{CL}$ plots both for dipterocarps and non-dipterocarps could not be positively explained $\left(\mathrm{P}_{\text {value }}=0.186\right.$ and $\mathrm{P}_{\text {value }}=$ 0.724 respectively). In other words, there is no positive correlation between diameter increment and felling intensity in $\mathrm{CL}$ plots for dipterocarps and non-dipterocarps.

Initial measurements that were conducted in 2000 shows that periodic annual diameter increment rate for all species in the CL block two years after logging was $0.28 \mathrm{~cm}_{\text {year }}{ }^{-1}$ and $0.48 \mathrm{~cm}$ year ${ }^{-1}$ for dipterocarps (Priyadi et al., 2002). Among the genera within dipterocarps, the fastest increment rates were Parashorea (0.59 $\mathrm{cm}$ year $\left.^{1}\right)$ and Shorea $\left(0.51 \mathrm{~cm}^{2}\right.$ year $\left.{ }^{1}\right)$, followed by Dipterocarpus $\left(0.35 \mathrm{~cm}\right.$ year $\left.^{-1}\right)$ and Vatica $\left(0.35 \mathrm{~cm}\right.$ year $\left.{ }^{1}\right)$.

In the RIL plots, the periodic annual diameter increment for all species after logging was 0.31 $\mathrm{cm}$ year ${ }^{1}$. The highest growth rates were exhibited by the families Fagaceae $\left(0.57 \mathrm{~cm}\right.$ year $\left.{ }^{-1}\right)$, the Clusiaceae (0.48) and the Dipterocarpaceae (0.35).

\section{Size-class distribution of the residual stand}

Based on an inventory of the regeneration plots after logging, the sapling density calculated from the census of the 12 plots $\left(5 \times 100 \mathrm{~m}^{2}\right.$ each) was more than $4600 \mathrm{stem} / \mathrm{ha}$ on average. The post-harvest distribution of trees by diameter class showed an 'inverse-J' distribution typical of uneven-aged, mixed forests. The inverse-J distribution was reasonably well maintained in the post-harvest distributions in the harvesting blocks (Figure 3).

The most important families in terms of species composition were Euphorbiaceae, Dipterocarpaceae, Myrtaceae and Lauraceae (Figure 4). There are 57 families and 453 genera found in the sapling stock for both RIL and CL plots. However, only 307 of the genera consist of more than 10 species. The Euphorbiaceae dominates $21.5 \%$ of the genera, followed by Dipterocarpaceae 13.3\%, Myrtaceae 10.4\% and Lauraceae $9.4 \%$. Those four families dominate $54.7 \%$ of total families represented in the regeneration plots.

\section{Logging damage assessment}

Logging damage is directly correlated to the felling intensity applied. In this study, felling intensities vary among treatments given. In CL plots, the average felling intensity was 7.3 trees /ha (equivalent to $83 \mathrm{~m}^{3} / \mathrm{ha}$ or $10.5 \mathrm{~m}^{3} /$ tree). Meanwhile, in the RIL plots the felling intensity was 6.8 trees/ha on average (equivalent to $60 \mathrm{~m}^{3} /$ ha or $9 \mathrm{~m}^{3} /$ tree). The total basal area removed in $\mathrm{CL}$ was significantly higher than that of RIL with $5.4 \mathrm{~m}^{2} / \mathrm{ha}$ and $3.8 \mathrm{~m}^{2} / \mathrm{ha}$, respectively (Table 6 ).

The correlation model between felling intensity and percentage of trees damaged in the plots both in RIL and CL was analysed by using SPSS 10. The regression lines for RIL, CL and both of them are shown below. There was a significant positive correlation between felling intensity and the proportion of trees damaged by RIL $\left(\mathrm{R}^{2}=\right.$ $0.571, \mathrm{P}=0.018)$, but not in $\mathrm{CL}\left(\mathrm{R}^{2}=0.086, \mathrm{P}=\right.$ 


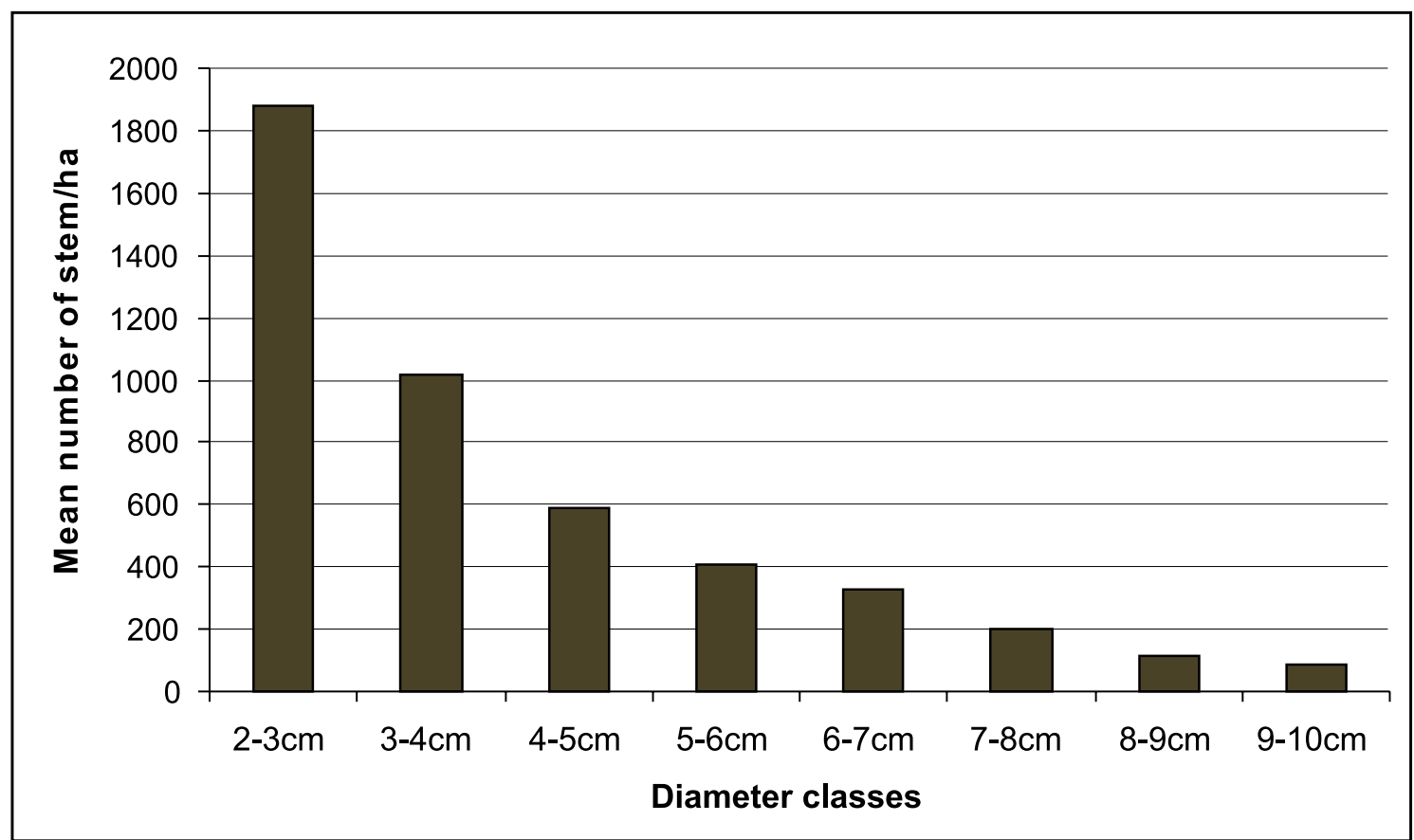

Figure 3. Distribution of the sapling by diameter classes (all plots, all species included)

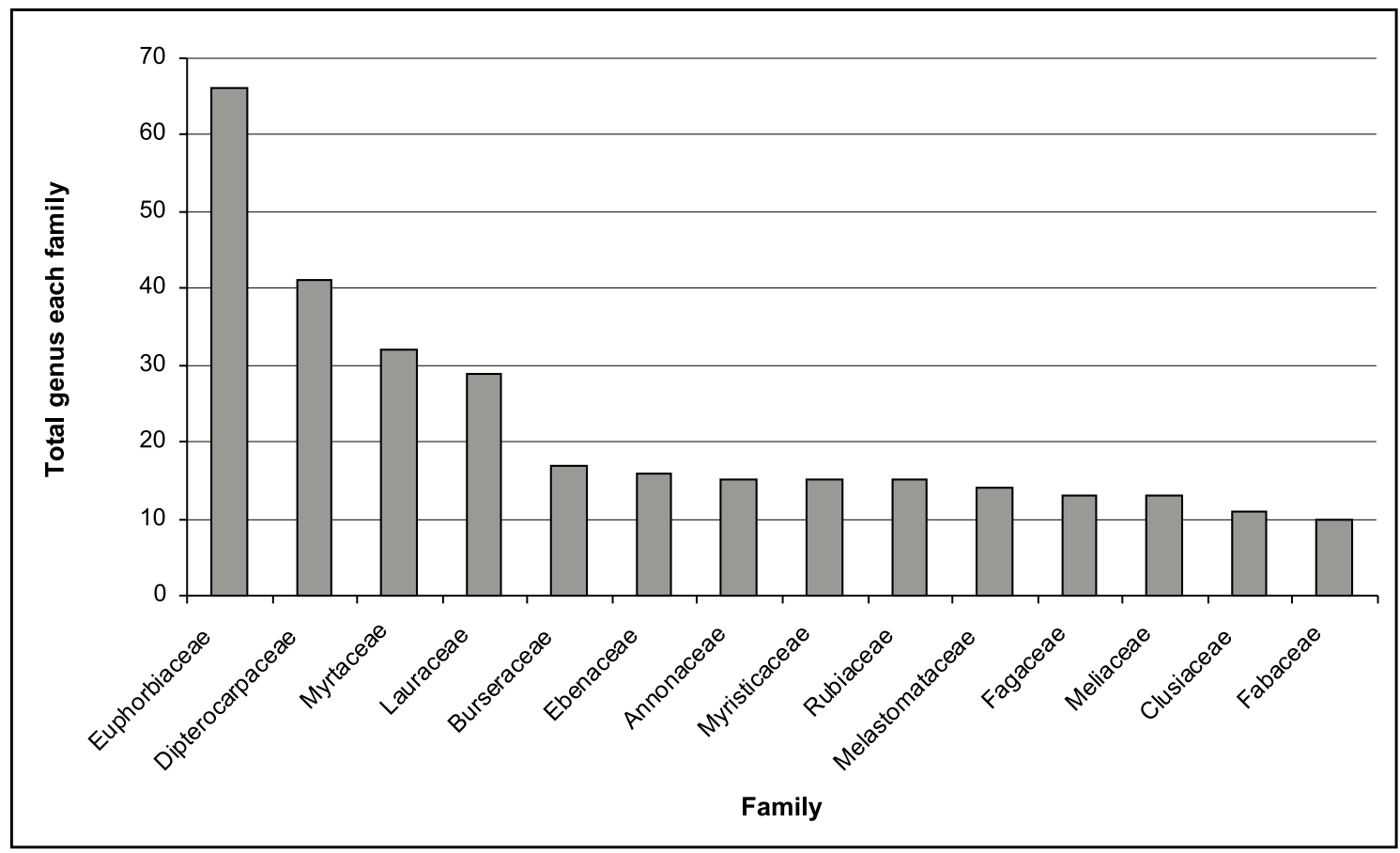

Figure 4. Proportion of the main families and genus in the sapling stock 
Table 6. Mean damage to residual stand (\%) against felling intensity (trees/ha)

\begin{tabular}{clccc}
\hline ID & $\begin{array}{l}\text { PLOTS } \\
\text { CODE }\end{array}$ & Y (Mean Damage) & X (Felling Intensity) & SD \\
\hline 1 & CL5 & 51.03 & 5 & 32.35 \\
\hline 2 & CL7 & 13.64 & 5 & 5.99 \\
\hline 3 & CL10 & 22.89 & 5 & 13.71 \\
\hline 4 & CL6 & 32.27 & 6 & 10.01 \\
\hline 5 & CL13 & 23.36 & 6 & 8.43 \\
\hline 6 & CL14 & 25.89 & 6 & 7.20 \\
\hline 7 & CL9 & 22.00 & 11 & 10.26 \\
\hline 8 & CL15 & 40.19 & 11 & 14.69 \\
\hline 9 & CL16 & 45.25 & 11 & 5.82 \\
\hline 10 & RIL1 & 11.48 & 3.5 & 5.53 \\
\hline 11 & RIL2 & 14.72 & 3.5 & 8.36 \\
\hline 12 & RIL3 & 8.40 & 7.5 & 5.32 \\
\hline 13 & RIL5 & 23.39 & 7 & 18.35 \\
\hline 14 & RIL6 & 20.85 & 7 & 10.53 \\
\hline 15 & RIL7 & 23.64 & 10 & 10.37 \\
\hline 16 & RIL9 & 16.24 & 10 & 21.04 \\
\hline 17 & RIL10 & 51.20 & 10 & 17.48 \\
\hline 18 & RIL11 & 41.54 & &
\end{tabular}

0.443). However, taken together the regression line of CL and RIL showed a positive correlation between felling intensity and the proportion of tree damaged $\left(R^{2}=0.295, P=0.02\right)$.

In CL plots, where felling intensity was considered as low, damage created was $27 \%$ in the size class diameter between $20-50 \mathrm{~cm}(\mathrm{n}=212$, SD $= \pm 7.9$ ) and $31 \%$ total damage in all residual stands ( $\mathrm{n}=262, \mathrm{SD}= \pm 6.6$ ). At the same time, $22 \%$ damage was created in the same diameter classes at medium felling intensity $(n=141, S D=$ $\pm 3.7)$, with total damage being $27 \%(n=210$, $\mathrm{SD}= \pm 4)$. Meanwhile, when felling intensity was considered as high (11 trees/ha), trees damaged in diameter between $20-50 \mathrm{~cm}$ was $27 \%$ ( $\mathrm{n}=$ $172, \mathrm{SD}= \pm 4.4)$, but the total trees damaged was $33 \%(n=215, S D= \pm 5)$.

Meanwhile in the RIL plots, where the felling intensity was considered low, the residual damage created in diameter class $20-50 \mathrm{~cm}$ was $10.5 \%(\mathrm{n}=81, \mathrm{SD}= \pm 3)$, and total damage for all diameter classes was $14.3 \%(n=262$,
$\mathrm{SD}= \pm 2$ ). With the felling intensity considered as medium, residual damaged of $20-50 \mathrm{~cm}$ diameter classes was $20 \%(n=163, S D= \pm 5.7)$, and $28 \%$ for all diameter classes $(n=268, S D=$ \pm 4.5 ). Meanwhile, with a high felling intensity, RIL created damage in diameter classes 20-50 $\mathrm{cm}$ which amounted to $29 \%$ ( $\mathrm{n}=239$, SD = $\pm 6.4)$, and for all diameter classes was $35 \%$ ( $n=$ $274, \mathrm{SD}= \pm 6$ ).

When residual stand damage both in RIL and $\mathrm{CL}$ is summarised, it is clear that when logging was implemented by involving low and medium intensity, RIL causes significantly less damage than those in CL. However, when felling intensity is high, there was no significant difference in damage in both RIL and CL.

\section{Canopy opening}

Before logging, mean canopy openings in $\mathrm{CL}$ (three plots) and RIL (nine plots) was 3.6\% and $3.1 \%$ respectively. The distributions of the values according to canopy openness classes in $\mathrm{CL}$ and 
(a)

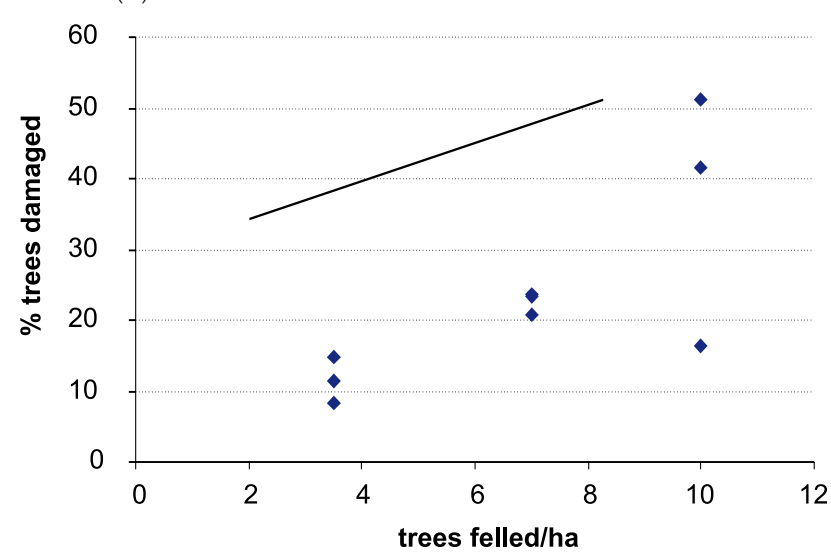

(b)

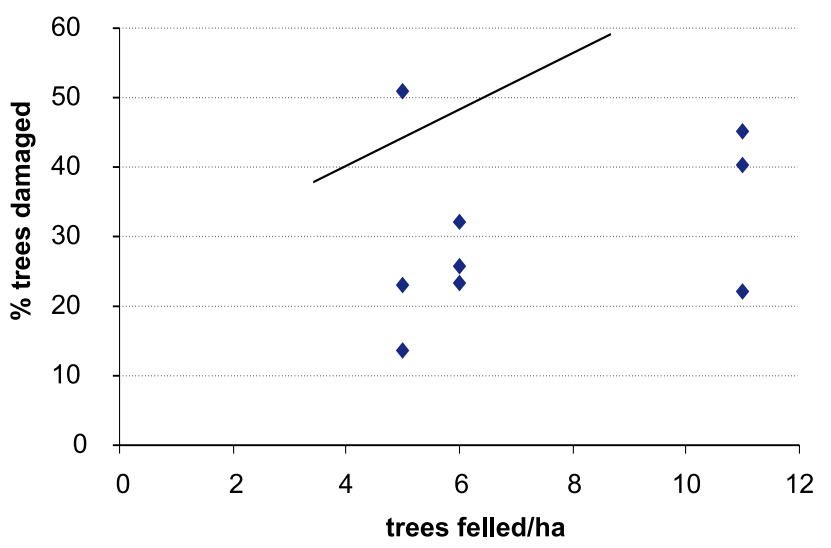

(c)

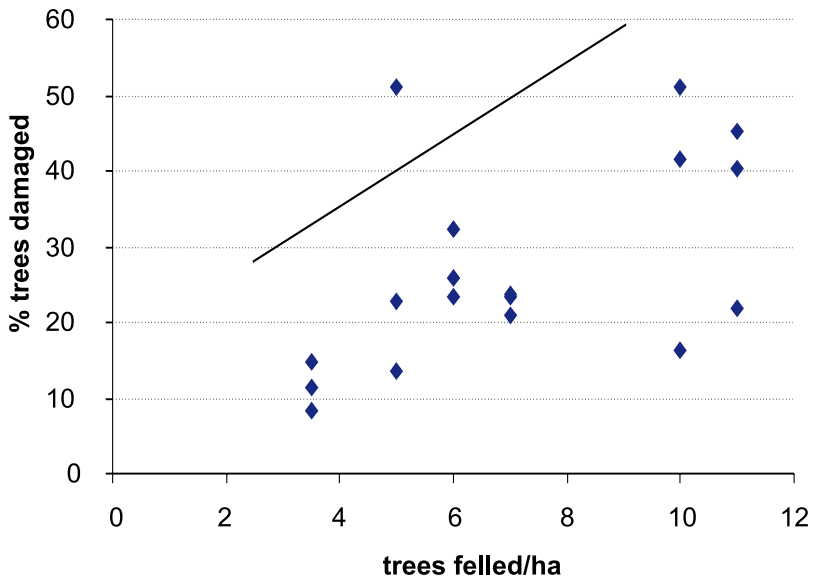

Figure 5. The correlation between felling intensity and percentage of trees damaged in RIL and conventional: (a) between felling intensity and total trees damaged

in RIL. Regression line for RIL $=Y=-2.449+3.797 \mathrm{X}$

(b) between felling intensity and total trees damaged in CL. Regression line for $C L=Y=21.152+1.306 X$ (c) between felling intensity and total trees damaged in $\mathrm{CL}$ and RIL. $Y=8.186+2.672 X$
RIL plots were similar. After logging, the mean canopy openness was $19.2 \%$ in CL ( $\mathrm{n}=9$ plots) and $13.3 \%$ in RIL ( $n=8$ plots). There was a higher proportion of measurements in the $0-5 \%$ canopy openness class and a lower one in the last class $(=30 \%)$ in RIL than in CL. Canopy openness was significantly correlated with felling intensity in RIL but not in $\mathrm{CL}$ (Pearson's $\mathrm{R}=0.84, \mathrm{P}<0.01$, $\mathrm{df}=7$ for RIL, $\mathrm{R}=0.33, \mathrm{P}=0.38 \mathrm{df}=8$ in $\mathrm{CL}$ ). Before logging, 108 measurements were taken in three CL plots and 324 measurements in 9 plots in RIL. After logging, the measurements in conventional were undertaken in nine logged plots (324 measurements), and eight logged plots in RIL (288 measurements) (before logging, $\mathrm{X}^{2}=2.73, \mathrm{P}=0.25$; after logging $\mathrm{x}^{2}=43.56$, $\mathrm{P}<0.001$ ).

\section{Soils and run-off}

Soils in Malinau's lowland dipterocarp forests in the study area are categorised as typic kanhapludults: strongly acid, infertile and potentially susceptible to surface erosion. Our study found that run-off and erosion rates in RIL forest blocks are slightly higher compared to those of CL blocks, yet a paired t-test indicates that statistically there are no significant differences between the logging regimes, so this probably reflects slope difference. However, the infiltration rate occurring in the RIL plots is slightly lower than that in the CL plots; yet again, this difference is not statistically significant. Note that the infiltration rate observed in both cases is reasonably high and ranging from $99.5 \%$ up to $100 \%$ for every rainy day.

In general, the soil bulk density found in the RIL plot and its associated skidding road is somewhat higher across all soil layers from the surface to the $50 \mathrm{~cm}$ soil depth compared with the corresponding layer of the $C L$ plot. Hence a lower infiltration rate observed in the RIL blocks coincides with higher soil bulk density. The difference in soil bulk density between the two logging regimes is statistically significant only at $0-5 \mathrm{~cm}$ and $30-50 \mathrm{~cm}$ soil depth. This phenomenon is explained by the fact that soil texture of the RIL plot is less clayey. The bulk density is affected by the structure of soil, namely its looseness or degree of compaction, as well as by its swelling and shrinking characteristics, which are dependent upon clay content. 
Table 7. Residual stands damaged in each diameter classes in CL plots

\begin{tabular}{lcccccccccccc}
\hline $\begin{array}{l}\text { Diameter } \\
\text { classes }(\mathbf{c m})\end{array}$ & $\mathbf{C L}$ & $\mathbf{C L}$ & $\mathbf{C L}$ & $\%$ & $\mathbf{C L}$ & $\mathbf{C L}$ & $\mathbf{C L}$ & $\%$ & $\mathrm{CL}$ & $\mathrm{CL}$ & $\mathrm{CL}$ & $\%$ \\
\hline $20-30$ & $\mathbf{5}$ & $\mathbf{1 0}$ & damage & $\mathbf{6}$ & $\mathbf{1 3}$ & $\mathbf{1 4}$ & damage & $\mathbf{9}$ & $\mathbf{1 5}$ & $\mathbf{1 6}$ & damage \\
\hline $30.1-40$ & 14 & 38 & 17.7 & 29 & 23 & 19 & 11 & 30 & 38 & 21 & 14 \\
\hline $40.1-50$ & 13 & 2 & 3 & 2.3 & 15 & 3 & 7 & 4 & 10 & 16 & 8 & 5 \\
\hline $50.1-60$ & 13 & 0 & 6 & 2.4 & 4 & 3 & 3 & 2 & 6 & 5 & 9 & 3 \\
\hline $60.1-70$ & 0 & 1 & 3 & 0.5 & 5 & 2 & 3 & 2 & 4 & 1 & 8 & 2 \\
\hline$>70$ & 4 & 0 & 4 & 1 & 3 & 5 & 3 & 2 & 2 & 1 & 4 & 1 \\
\hline Total damage & 148 & 27 & 68 & 31 & 71 & 50 & 51 & 28 & 66 & 84 & 62 & 33 \\
\hline
\end{tabular}

Table 8. Residual stands damaged in each diameter classes in RIL plots

\begin{tabular}{|c|c|c|c|c|c|c|c|c|c|c|c|c|}
\hline \multirow{2}{*}{$\begin{array}{l}\text { Diameter } \\
\text { Classes }(\mathrm{cm})\end{array}$} & RIL & RIL & RIL & $\%$ & RIL & RIL & RIL & $\%$ & RIL & RIL & RIL & $\%$ \\
\hline & 1 & 2 & 3 & damage & 5 & 6 & 7 & damage & 9 & 10 & 11 & damage \\
\hline $20-30$ & 14 & 23 & 14 & 6 & 48 & 29 & 30 & 13 & 29 & 61 & 50 & 17 \\
\hline $30.1-40$ & 10 & 7 & 3 & 3 & 11 & 8 & 15 & 4 & 8 & 23 & 25 & 7 \\
\hline $40.1-50$ & 3 & 4 & 3 & 1 & 7 & 5 & 10 & 3 & 6 & 22 & 15 & 5 \\
\hline $50.1-60$ & 2 & 2 & 1 & 1 & 1 & 3 & 4 & 1 & 1 & 13 & 9 & 3 \\
\hline $60.1-70$ & 0 & 1 & 0 & 0 & 1 & 2 & 3 & 1 & 5 & 5 & 4 & 2 \\
\hline$>70$ & 2 & 2 & 0 & 0 & 1 & 2 & 3 & 1 & 2 & 4 & 5 & 1 \\
\hline Total damage & 31 & 39 & 21 & 11 & 69 & 49 & 65 & 23 & 51 & 128 & 108 & 35 \\
\hline
\end{tabular}

Table 9. Residual stand damaged both in CL and RIL according to class diameter

\begin{tabular}{lcccccc}
\hline \multirow{2}{*}{ Diameter class } & \multicolumn{7}{c}{ Residual stand damage (\%) } \\
\cline { 2 - 8 } & Low & Medium & High & Low & Medium & High \\
\cline { 2 - 7 } & 10 & 20 & 29 & 27 & 22 & 27 \\
\hline $20-50 \mathrm{~cm} \mathrm{dbh}$ & 1 & 3 & 6 & 3.9 & 6 & 6 \\
\hline$>50 \mathrm{~cm} \mathrm{dbh}$ & 1 & & & &
\end{tabular}

Table 10. Percentage of each canopy openness class in RIL and CL plots

\begin{tabular}{lccccc}
\hline & \multicolumn{5}{c}{ Canopy openness (\%) } \\
\cline { 2 - 6 } & $\mathbf{0 - < 5 \%}$ & $\mathbf{5 - < 1 0 \%}$ & $\mathbf{1 0 - < 2 0 \%}$ & $\mathbf{2 0 - < 3 0 \%}$ & $\mathbf{3 0 \%}$ \\
\hline Before logging & & & & \\
\hline CL & $80.6(87)$ & $12(13)$ & $7.4(8)$ & - & - \\
\hline RIL & $81.8(265)$ & $14.5(47)$ & $3.7(12)$ & - & - \\
\hline \multicolumn{7}{c}{} \\
\hline
\end{tabular}


(a)

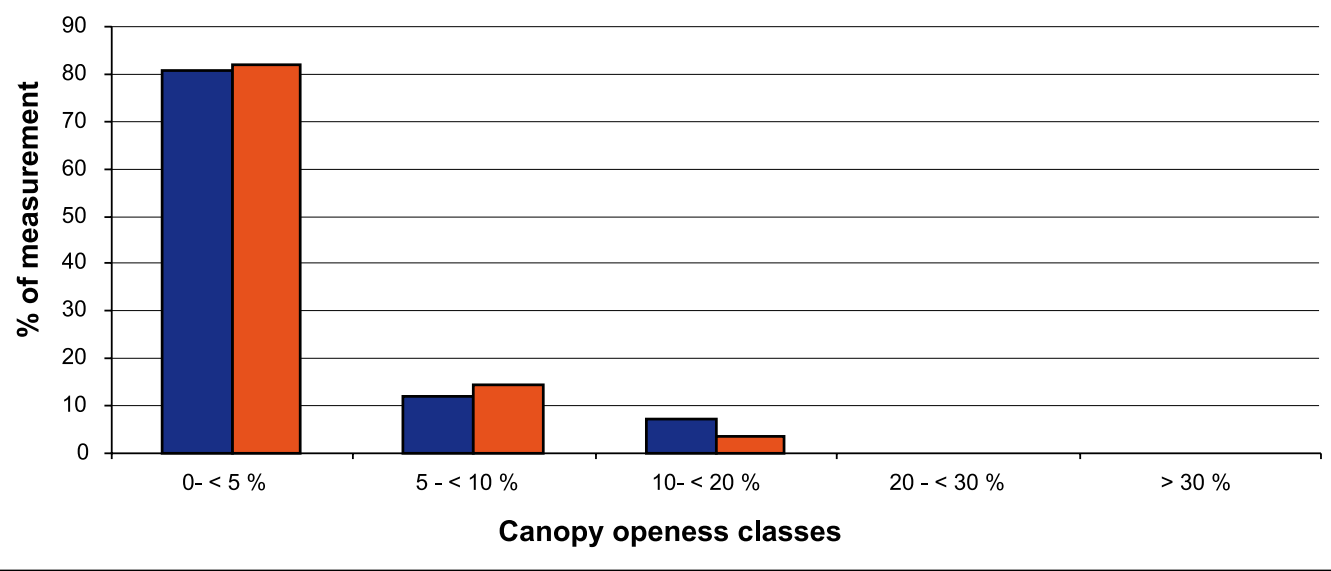

(b)

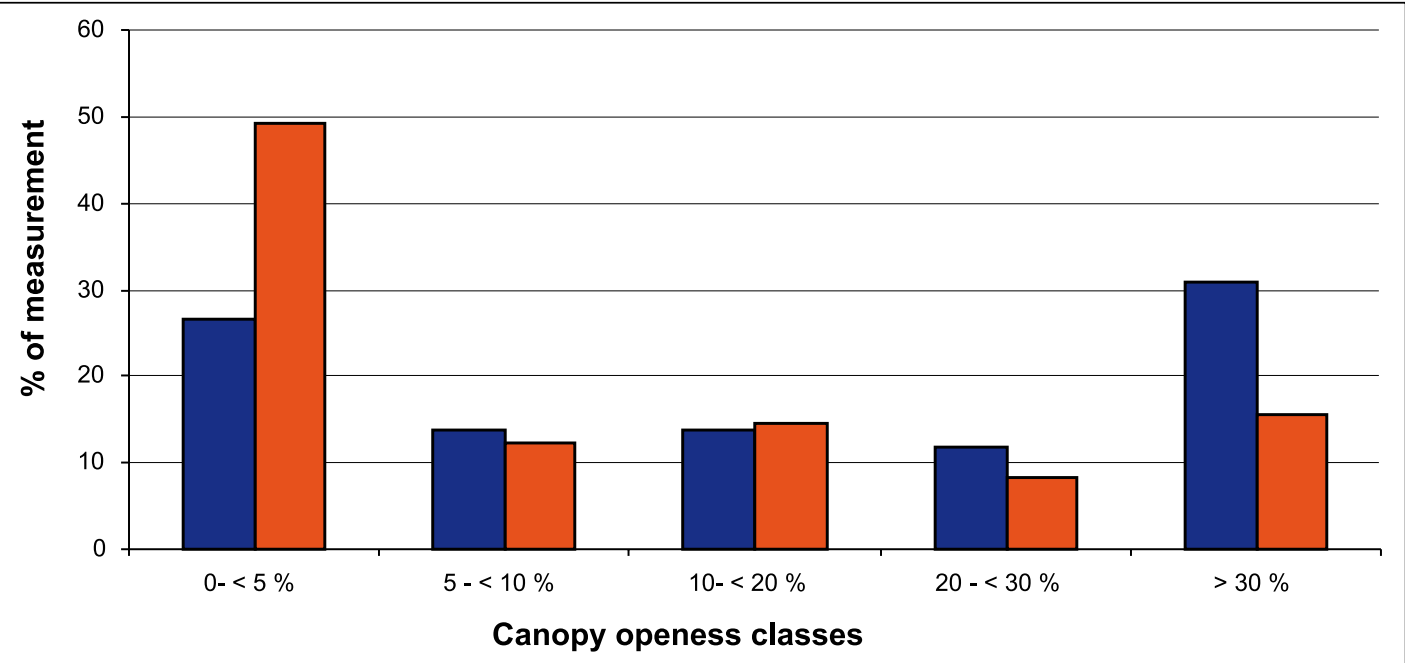

Figure 6. Percentage of canopy openness measurements in each canopy class in CL (blue bars) and RIL (orange bars): a) before logging, b) after logging

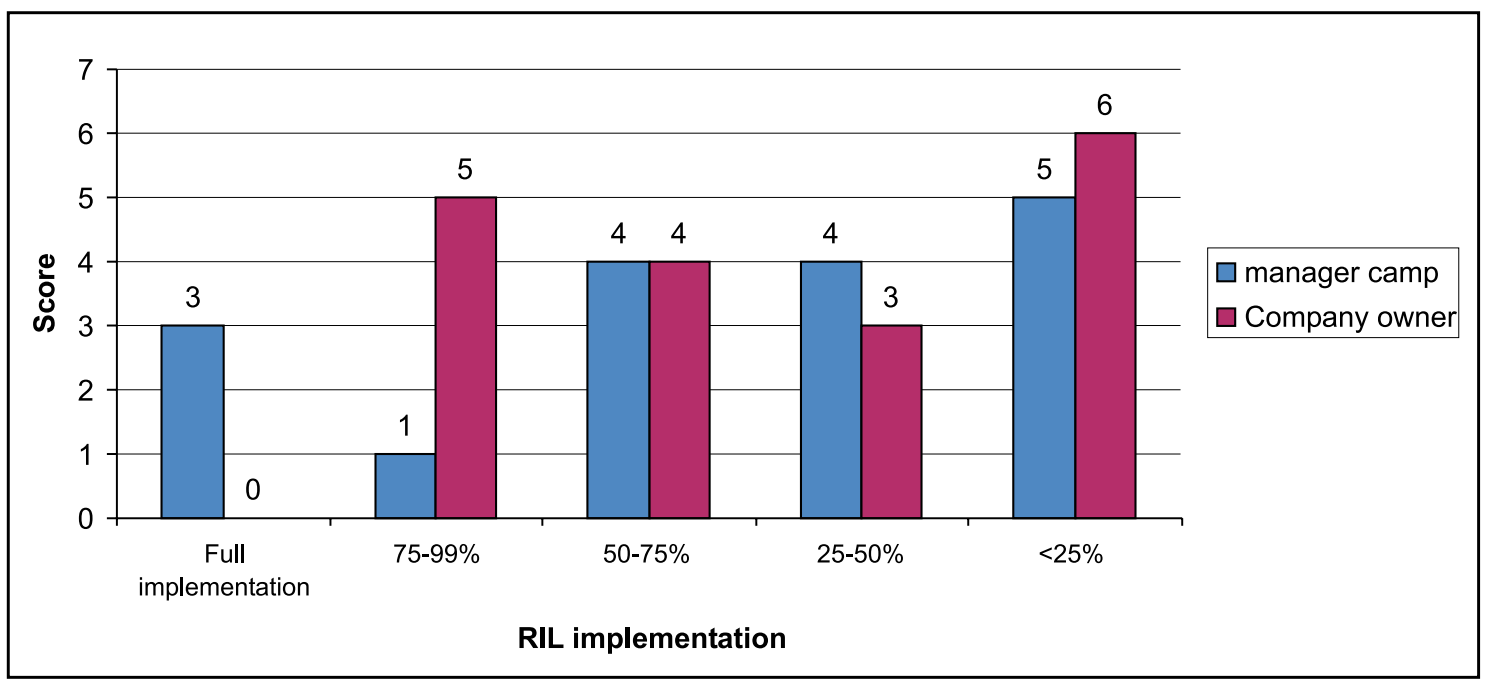

Figure 7. Results of the adoption survey of camp managers and company owners in relation to how far they are implementing RIL 


\section{RIL adoption}

From the adoption study which was undertaken by CIFOR in conjunction with TFF, three companies have implemented RIL in their operations, according to interviews with the company operations manager. However, according to the company's owners', most companies have only implemented RIL techniques on only $25 \%$ of their forest area. This discrepancy in the perceptions between operations manager and company owner suggests the latter is not fully conversant with the field operations of his/her company. It is clear from Figure 6, however, that adoption of RIL remains limited.

Clear disincentives to the implementation of RIL were observed, although most disincentives were caused by external factors. Based on number of responses, the 11 factors we listed are as follows: land uncertainty (71), land claim by community (30), illegal logging (27), conflict over land use (26), management is not supportive (26), further training is required (15), lack of staff capacity (10), additional cost of implementation is too high (10). Meanwhile, two disincentive factors that received a small score were the need to invest in improved technology (4) and that RIL is not required by the government (2).

\section{DISCUSSION AND \\ MANAGEMENT IMPLICATIONS}

\section{Felling, skidding and residual stand damage}

When compared with conventional harvesting practices, RIL reduced the number of trees damaged by $40 \%$. However, the proportion of trees damaged was similar in both techniques, particularly in the higher intensity logged areas, suggesting that RIL is only effective under low to medium logging intensities. These findings concur with those of Sist and The (2002) in Berau, also in East Kalimantan. In this study, it was demonstrated that damage caused by felling is different from that caused by skidding. Felling primarily injured trees $30-50 \mathrm{~cm}$ in dbh whereas skidding caused substantial mortality of small trees, $10-20 \mathrm{~cm}$ dbh. The main benefit of RIL was to reduce skidding damage from $25 \%$ of the original stand in CL to only $9.5 \%$. As skidding operations are one of the major causes of mortality of the residual stand, the low proportion of trees killed or damaged in RIL appears to result from improved skidding.

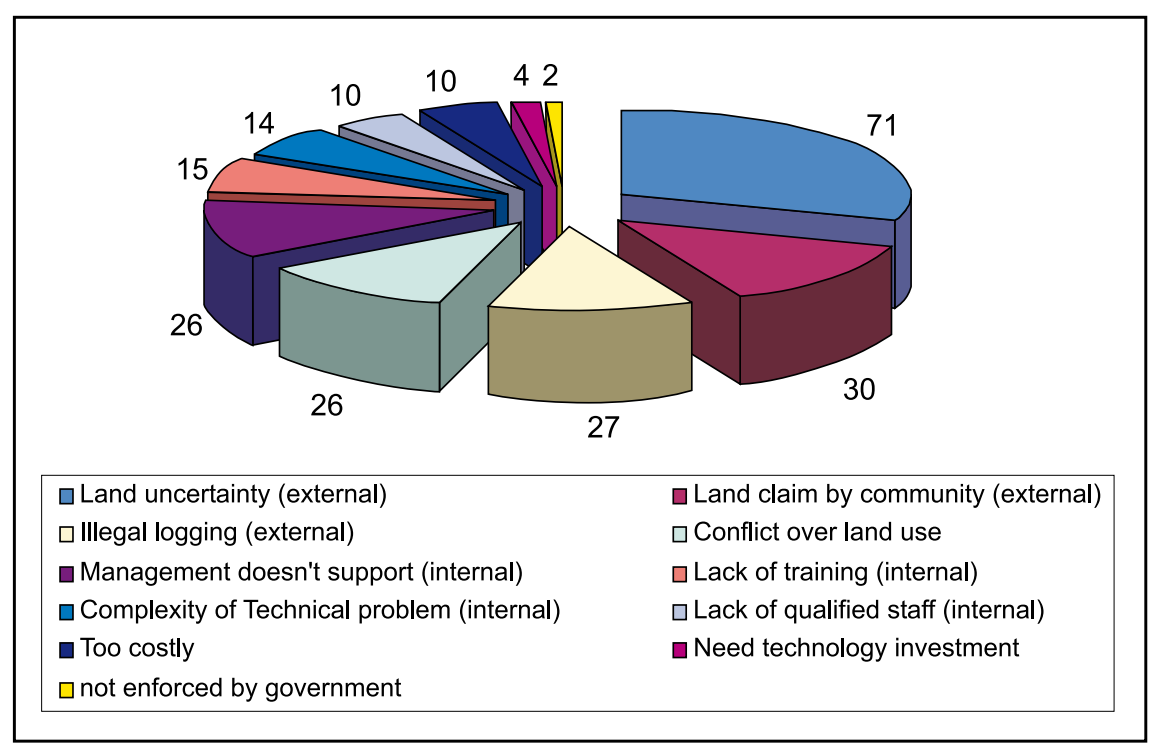

Figure 8. Disincentive factors for logging companies in implementing RIL (in number of responses) 
The careful application of directional felling also had an impact on sustainable practices, notably the improved recuperation rates of trees that were felled where access could be gained to them. Directional felling also aims to complement skidding by laying the logs in positions that facilitate ground skidding extraction and limit skidding damage on the remaining stand. It is important to note that in RIL operations, skidding damage is correlated to felling intensity, whereas in conventional logging this is not the case. Clearly, this study shows that most of the damage incurred during logging operations can be effectively reduced through the application of improved extraction methods.

Logging damage could also be reduced by instituting pre-felling climber cutting. This activity is usually undertaken as a silvicultural treatment after harvesting, aimed at liberating and enhancing the growth of preferred crop trees. However, Azman et al. (1999) showed in his study in Pahang (Peninsular Malaysia) that out of 3,000 trees tagged for felling about $15 \%$ were infested with climbers that could potentially inflict serious damage to neighbouring trees. By cutting the climbers about 10 months prior to felling, it was found that they had all decayed and did not inflict damage to their neighbouring trees during the actual felling operation.

\section{Species composition}

Although in terms of forest structure, measurements taken after logging show that the typical inverse J-shaped curve reflects the high regeneration potential of the forest, there is a distinct species shift in regrowth vegetation. For example, in conventional logging where the canopy opening was greater, many species of the Euphorbiaceae were recorded in the resultant successional vegetation, many of which are pioneer species, such as Macaranga spp. Although many Dipterocarpaceae are also light demanders, their regeneration is ultimately affected by the increased competition from

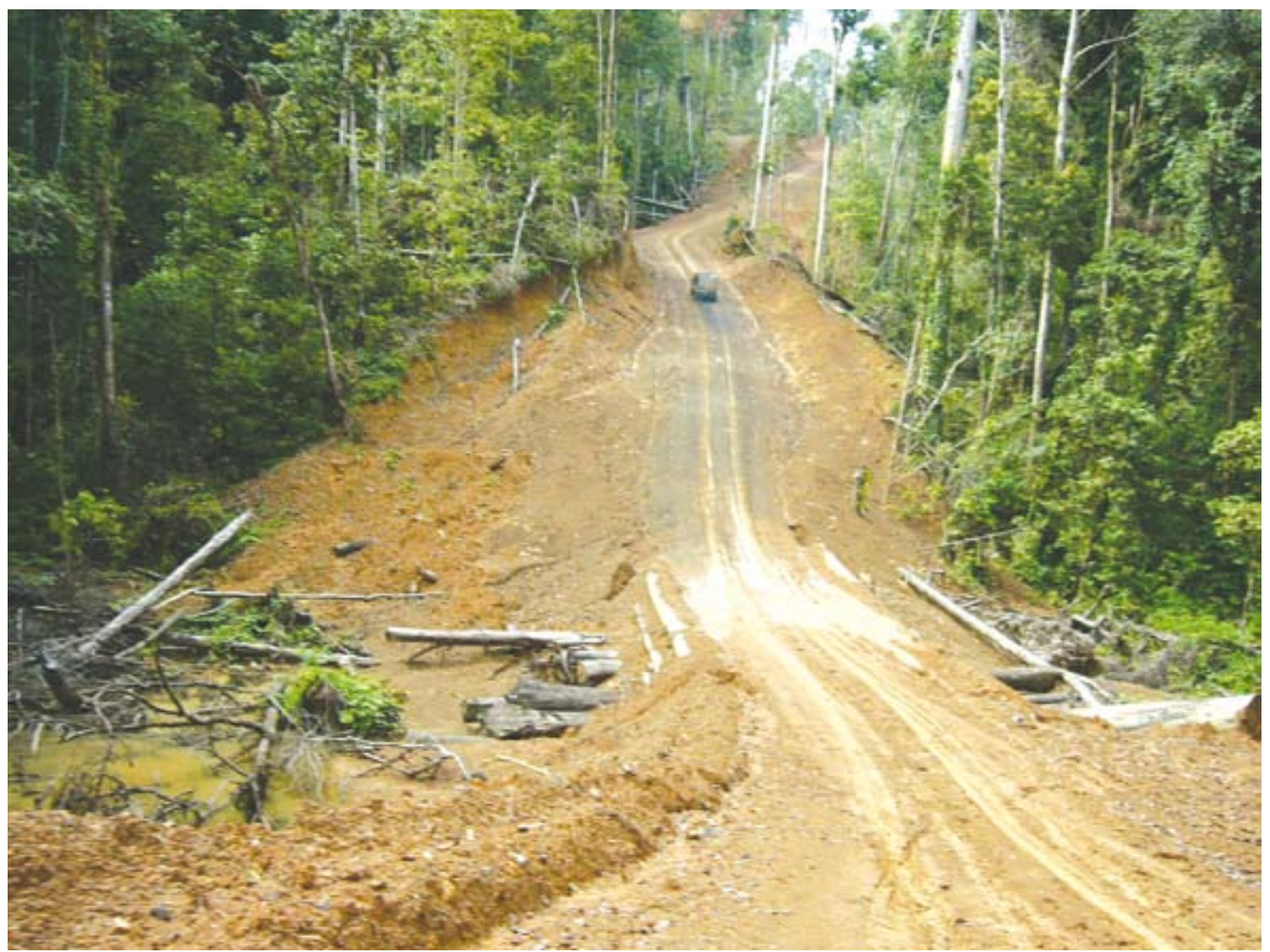

Common view of logging road in conventional logging block (Photo by Markku Kanninen) 
pioneer species, and cohorts of dipterocarps may take much longer to establish (van Gardingen et al., 1998). Hence while species richness per se remains unaffected, there is a distinct species shift to more early successional taxa that do not have potential timber value. A similar situation is recorded in the forests of Central Africa where logged-over forests create conditions that do not allow for the regeneration of shade-tolerant mahoganies (Sunderland and Balinga, 2005).

\section{Soil and run-off}

In terms of soil and run-off, our studies concluded that there was no significant difference between $\mathrm{CL}$ and RIL logging operations in terms of run-off, soil erosion rate and infiltration rate observed four years after logging activities had ceased. However, leaching of potassium and phosphorous was greater in the CL blocks due to less canopy interception of rainfall. Clearly issues of soil fertility are important, and if leaching is reduced under RIL, then its effects are beneficial.

\section{Lack of adoption of RIL}

In the case of Indonesia, we observe that only a few timber companies implement RIL in their concessions. This is due to a number of factors both internal and external, which include the lack of government policy or guidance on the subject, lack of capacity of staff, both technical and managerial, and a perception that RIL costs more to implement than conventional logging (Priyadi et al., 2006).

The lack of awareness and appreciation of the benefits of RIL is particularly true at the important decision-making levels in governments and the private sector. Without strong leadership from above, progressive mid-level managers and field workers and supervisors have little incentive to change the status quo, although there are exceptions to the rule (Suparma et al., 2001). In the case of Malinau, Sustainable Forest Management (SFM) in the Forest Management Unit of state-owned company PT Inhutani II was not implemented due to the fact that the company is forced by local government to subcontract its logging operation to a third party. As such, regulation is difficult.

\section{Implications for policy}

This research has also revealed shortfalls in the regulations outlined by TPTI. For example, the $1 \mathrm{~cm}$ diameter increment on which logging extraction limits are based is not reliable (given our calculations of dipterocarps of between 0.35$0.62 \mathrm{~cm} /$ year). As such, current harvest levels are too high and perhaps the current 35-year rotation too short to ensure adequate recovery post-logging. The TPTI regulations should also include specific guidelines for the preparation of a coherent management plan and also prescribe the need for topographical maps to assist in felling and skidding operations so that skid trails can be planned and accurately located. TPTI regulations should also recommend climber cutting prior to felling, the practice of directional felling and better post-harvest inventory and monitoring.

Illegal logging and unplanned forest conversion represent major deterrents to the implementation of RIL (Smith and Applegate, 2001). The lack of trained and experienced personnel is the most critical requirement for the successful application of RIL on a wide scale, particularly the availability of skilled logging personnel (Dykstra, 2001). Most countries in Asia and the Pacific have adequate laws governing forest harvesting and management. What is lacking are not laws and regulations, but rather effective enforcement and incentives for compliance. However, a policy review should take place to modify the current TPTI regulations to reflect the added need for a more rigorous regulatory framework required for the implementation of RIL.

\section{CONCLUSION}

RIL techniques have been shown to reduce the deleterious impact on the residual stand and on wider biodiversity, but only if the logging intensity is moderate (a maximum of 8 trees/ha). A reduced felling intensity would have benefits, not only on the regeneration and growth of the residual stand, but also for the long-term ecological sustainability of the forest. The implication is that new silvicultural prescriptions, such as those described above, need to be further developed and implemented in order to improve harvesting operations. 


\section{REFERENCES}

Azman, H., Ismail, H. \& Mohd. Ridza, A. 1999. Climber cutting before felling: an evaluation towards implementation. Paper presented to the 36th meeting of MAJURUS, Kuala Terengganu, Terengganu, Malaysia.

Barreto, P., Amaral, P., Vidal, E. and Uhl, C. 1998. 'Costs and benefits of forest management for timber production in eastern Amazonia'. Forest Ecology and Management. 108: pp. 9-26.

Dwiprabowo, H., Grulois, S., Sist, P. and Kartawinata, K. 2002. Cost-benefit analysis of reduced-impact logging in a lowland dipterocarpforestofMalinau, East Kalimantan. Technical Report of ITTO Project PD 12/97 Rev. 1(F), Forest Science and Sustainability: The Bulungan Model Forest, Phase I: $1997-$ 2001, pp. 39-55.

Dykstra, Dennis P. 2001. Reduced impact logging: concepts and issues. Paper presented at the International Conference on Application of Reduced Impact Logging to Advance Sustainable Forest Management: Constraints, Challenges and Opportunities, 26 February to 1 March 2001, Kuching, Sarawak, Malaysia.

Elias, T. Applegate, G., Kartawinata, K., Machfudh and Klassen, A. 2001. Pedoman ReducedImpact Logging di Indonesia. CIFOR, Bogor, Indonesia.

Holmes, T.P., Blate, G.M., Sweede, J.C., Pereira, R., Barreto, P., Boltz, F. and Bauch, R. 1999. Financial costs and benefits of reduced impact logging relative to conventional logging in the Eastern Amazon. Tropical Forest Foundation and the USDA Forest Service.

Hout, van der, P. 1999. Reduced-impact logging in the tropical rain forest of Guyana. Tropenbos-Guyana Series 6. 335pp.

Jennings, S.B., Brown, N.D. and Sheil, D. 1999. 'Assessing forest canopies and understorey illumination: canopy closure, canopy cover and other measures'. Forestry. 72: pp. 5973.

Kartawinata, K., Priyadi, H., Sheil, D., Riswan, S., Sist P. and Machfudh. 2006. A field guide to the permanent sample plots in the reducedimpact blocks 27 at CIFOR Malinau research forest East Kalimantan. CIFOR, Bogor, Indonesia).131 pp. ISBN: 9792446303.
Natural Resource Management Project (NRM) 1994. Avoidable logging waste. USAID Report No. 37. Jakarta, Indonesia.

Priyadi, H., Gunarso, P., Sist, P. and Dwiprabowo, H. 2006. 'Reduced-impact logging (RIL) Research and Development in Malinau Research Forest, East Kalimantan: A challenge of RIL adoption'. In: Tantra, M.G., T. Elias.,Supriyanto (eds.) Proceedings ITTOMoF Regional Workshop: RIL Implementation in Indonesia with reference to Asia-Pacific Region: Review and Experiences. ITTO and MoF Indonesia. Pp. 147-67. ISBN: 97925 $8370 \mathrm{X}$.

Priyadi H., Kartawinata, K., Sist P. and Sheil, D. 2002. 'Monitoring Permanent Sample Plots (PSPs) after conventional and Reduced Impact Logging in the Bulungan Research Forest, East Kalimantan, Indonesia'. In: Shaharuddin bin Mohammad Ismail, Thai See Kiam, Yap Yee Hwai, Othman bin Deris and Svend Korsgaard (eds). Proceedings of The Malaysia-ITTO International workshop on growth and yield of managed tropical forest. 25-29 June 2002, Pan Pacific Hotel, Kuala Lumpur, Malaysia. Forestry Department Peninsular Malaysia. pp. 226-35.

Putz, F. 1994. Approaches to sustainable forest management. CIFOR Working Paper No. 4.

Sist, Plinio., Sheil, D., Kartawinata, K. and Priyadi, H. 2003. 'Reduced Impact Logging in Indonesian Borneo: some results confirming the needs for new silvicultural precriptions'. Forest Ecology and Management 179 (2003) pp. 415-27.

Sist, P. and Nguyen-The', N., 2002. 'Logging damage and the subsequent dynamics of a dipterocarp forest in East Kalimantan (19901996)'. Forest Ecology Management. 165, pp. 85-103.

Sist, P. Dykstra, D. and Fimbel, R. 1998. ReducedImpact logging guidelines for lowland and hill dipterocarp forests in Indonesia. CIFOR Occasional Paper No. 15.

Smith, J. and Applegate, G. 2001. Could trade in forest carbon contribute to improved tropical forest management? Paper presented at the International Conference on Application of Reduced Impact Logging to Advance Sustainable Forest Management: Constraints, Challenges and Opportunities, 26 February to 1 March 2001, Kuching, Sarawak, Malaysia. 
Sunderland, T.C.H. and Balinga, M.P.B. 2005. Evaluation preliminaire de la vegetation du parc national de Nouabale-Ndoki et de sa zone tampon, Congo. Une rapport pour le "Central African Regional Program for the Environment" (CARPE). http://carpe. umd.edu/resources/Documents/rpt smithsonian_ndoki_june05_french.pdf/view Suparma, Nana, Harimawan, and Hardiansyah, Gusti. 2001. Implementing reduced impact logging in the Alas Kusuma Group. Paper presented at the International Conference on Application of Reduced Impact Logging to Advance Sustainable Forest Management: Constraints, Challenges and Opportunities, 26 February to 1 March 2001, Kuching, Sarawak, Malaysia.
Van Gardingen, P.R., Clearwater, M.J., Nifinluri, T., Effendi, R., Ruswantoro, P.A., Ingleby, K. and Munro, R.C. 1998. 'The impacts of logging on the regeneration of lowland dipterocarp forest in Indonesia'. International Forestry Review. 77: pp. 71-82. 



\section{CHAPTER 8 COMMUNITY-BASED FORESTRY AND MANAGEMENT PLANNING}

Godwin Limberg, Ramses Iwan, Moira Moeliono, Made Sudana and Eva Wollenberg 


\section{INTRODUCTION}

Indonesia is one of the few countries in Asia that has yet to implement nationwide policies to devolve communities' access to state forests. Despite more than two decades of experience in social forestry in Java, increasing experience of local projects throughout the country and lessons available from similar policies implemented elsewhere in Asia (e.g. Kumar, 2002; Adhikari and Lovett, 2006; Salam and Noguchi, 2006) most villagers in Indonesia's outer islands remain without formal rights to State forest land. Yet at least 50 million people are dependent on Indonesia's forests (Brown, 2004). Moreover, between $62 \%$ and $75 \%$ (estimates differ) of Indonesia's land has been demarcated as State forest; consequently there is considerable potential to ensure that local communities receive sustained benefits from these forests if appropriate policies are devised and implemented. A pivotal element of such supportive policies would be the involvement of local communities in decision-making, planning and management of their local forest resources. Recent changes in the political climate (reformasi) and implementation of regional autonomy would seem to increase opportunities for development of community forestry.

This parallels work undertaken internationally over the last two decades in the fields of both community or social forestry (or Participatory Forestry Management [PFM] and Communitybased Natural Resource Management [CBNRM]). Both these paradigms or philosophies are applicable to the Malinau situation, and both have their foundations in the dual aims of promoting the conservation of natural resources on the one hand, whilst simultaneously reducing the vulnerability of local livelihoods in remote rural areas of the developing world (Turner, 2004). To these have been added the growing recognition of the need for social equity and recognition of the knowledge, rights and responsibilities of local communities to manage their own resources, especially as in many situations central government seemingly has neither the will nor the resources to do so from afar. The need for local involvement in management and sharing of benefits from forest resource use is strongly enshrined in the international Convention on Biological Diversity. Case studies have been documented internationally that develop principles and guidelines for implementing PFM or CBNRM projects (e.g. Oström, 1990; Lise, 2000; Agrawal, 2001; Fabricius et al., 2004), albeit almost exclusively from the perspective of external agencies. Thus, there is much that can be adapted for the Indonesian situation, whilst simultaneously offering new insights for international agencies by the specific contexts and histories of the Malinau area.

With this potential in mind, CIFOR has been working to develop approaches and models for community forestry, taking local conditions and contexts into account, and the Malinau Research Forest has been an important study area in this regard. Within the context of this chapter, we define community forestry as forestmanagement systems where local communities have some level of influence over decisions related to forest management or benefits (Warta Kebijakan, 2003). This chapter considers initiatives undertaken between 2002 and 2005, working with villagers to develop local landuse plans and options in forest areas under their jurisdiction and with district government better to understand villagers' needs in relation to the use of these forest areas. However, the development of community forestry in Malinau faces some fundamental problems that have to be resolved before community forestry can be applied on any scale. Some of these are likely to apply elsewhere in Indonesia. We describe those further below. Our objectives were to work with communities and local government to:

(1) Inform people about their existing policy choices and strengthen their ability to contribute to the development of forest policy in Malinau.

(2) Support communities in the development of village land-use plans to facilitate their own local planning as well as providing better links to district land-use planning processes.

(3) Facilitate communities and local government to have better participation, communication and conflict management to coordinate decisions together and build a common understanding for integrated resource management.

(4) Develop community forest pilot projects. 


\section{APPROACH}

CIFOR worked through a resident field team of 2-3 staff based in the Malinau River watershed. The work focused on the 27 villages in this watershed, with more intensive activity being undertaken in two villages. We also liaised with government officials in Malinau, especially in the Community Empowerment Service, Planning Agency and District leaders' office. We used a series of public meetings, informal consultations, publications and training sessions. Particular activities were as follows:

- Broad-scale initiatives:

- To provide information about the legal basis for communities to participate in land-use planning and the legal options available to them.

- To develop land-use planning and governance visions and principles with villagers and government officials.

- Case-study villages:

- To support the development of facilitation skills among community members from four villages to build local capacities to organise across and within communities.

- To conduct inventories of valuable forest products (timber, gaharu and rattan), endangered or threatened plant species and conservation needs (including habitats requiring protection), and use the information in developing land-use plans.

- To produce base maps and land-use maps for two case-study villages.

- To assess forest-based economic options in case-study villages.

- To support community members in presenting their proposals for land use to local government.

- Training initiatives:

- Support training in gaharu inoculation for representatives of 22 villages and more intensively in four case-study villages.

- Support cross-visits to other sites in East Kalimantan, Jambi and Nusa Tenggara Timur (NTT) to learn about community management experiences there.

\section{SITE DESCRIPTION}

The two case-study villages were Setulang and Sengayan. The following information is drawn from the report by Sidiyasa et al., (2006):

\section{Setulang}

Setulang village was established in 1968 and formally recognised (and boundaries designated) by an official decree of the Bulungan Regent in 1974. However, the status of the village is not accepted by all stakeholders, with different parties making claims on the surrounding forests and the timber they contain. As of December 2002 it had 851 inhabitants, primarily of the Oma' Long ethnic group originating from Long Sa'an in the Pujungan sub-district. The inhabitants practise shifting cultivation and maintain associated tree crops. They use their produce for direct household provisioning and sell any surplus, particularly their upland rice which is very popular in other villages and Malinau town. The Setulang villagers feel they have sufficient produce from their fields and gardens. Many of the young people travel to Malaysia, mainly to work in timber companies, and wages earned are used to buy assets such as generators or outboard motors, and also to build houses.

Between 2000 and 2002 the villagers set aside approximately $50 \%(5,300 \mathrm{ha})$ of their primary forest lands as a protected forest area, which is locally designated as Tane' Olen. This was prompted by two reasons. Firstly, during the 1970s they had unsatisfactory experiences with logging companies in the area, which resulted in damage to the forest and the resources they collected, as well as pollution to the rivers. Consequently, they were wary of any interaction or agreements with logging companies in the future. Secondly, with the advent of IPPK concessions (Izin Pemungutan dan Pemanfaatan $K a y u)$, they were approached by more than one company in the early 2000 s for an agreement to log the forests under their control, in common with several neighbouring villages. However, the Setulang villagers were concerned that the companies would damage their land and thus wished to give it a greater degree of protection 
by formally declaring it as Tane' Olen. They also wished to ensure that they would have access to key forest resources (especially building materials) in the future, and sufficient land for agricultural expansion. The district government has verbally supported Setulang's conservation initiative and adjusted development plans to avoid potential negative impacts on the protected forest. In 2003, the local government also started to mediate between Setulang and a neighboring community to try to resolve an outstanding boundary dispute.

The area of Tane' Olen $\left(3^{\circ} 23^{\prime}-3^{\circ} 29^{\prime} \mathrm{N}\right.$ and $116^{\circ} 24^{\prime}-116^{\circ} 29^{\prime}$ E) has undulating to hilly terrain with steep slopes. The altitude ranges between $150 \mathrm{~m}$ and $500 \mathrm{~m}$ above sea level and is dissected with numerous small streams all flowing into the Setulang River. The forest condition was estimated from a field survey supported by analysis of satellite imagery (Landsat TM-7 Band 542 Path/Row 117/58 scale 1:100 000 coverage, 23 January 2003) and is reported to be in good condition with localised signs of disturbance.

The residents defined the purpose of the Tane' Olen as a means of protecting their source of clean water, allowing for sustained use of forest products and for hunting. After designating the protected forest, they developed customary rules to regulate management and use of the forest. They also established a management body to coordinate and control management. The community built a guard post at the edge of the protected forest as a base for regular surveillance trips. Additionally, they have started erecting signs to increase awareness about existing regulations.

During the IPPK boom (2000-3) two incidents of encroachment by logging companies into the protected forest occurred. The community stopped the encroachment by confiscating heavy equipment, but the subsequent negotiations between the community, company and the district government to solve the conflict were not successful. In one case the company was fined, but only $50 \%$ of the total fine was paid. In the second case, although the encroachment stopped, no sanctions were taken against the logging company.

\section{Sengayan}

The village of Sengayan is located half way down the Malinau River. It has a large area of forest, including 3,325 hectares of production forest located along the boundary with the village of Adiu downstream and Peang Kocop upstream of the Sengayan River, which is a tributary of the Malinau. Sengayan had a population of 280 people (70 families) in December 2002, mostly from the Merap ethnic group, and some migrants from other islands who had previously worked in the nearby coal-mine and subsequently married local women. The terrain is undulating, hilly to mountainous, dissected by several streams flowing into the Sengayan River, such as the Prokem and Maketi upstream, and the Lunuk, Peang Kocop and Pelancau rivers downstream. The altitude varies between 150 and $700 \mathrm{~m}$ above sea level.

Since decentralisation and the revision of forestry laws to enable small-scale logging on village territory in 1999, the people of Sengayan have been eager to cooperate with logging companies to exploit part of their forest. In 2000 a logging company obtained a timber-harvesting licence based on an agreement with the villagers of Sengayan to exploit 2,000 hectares within the village territory of about 10,000 hectares. These operations ended in 2003 when the licence expired and became illegal. The main benefit for community members was additional cash income through fee payments (Rp 20,000 $\mathrm{m}^{-3}$ of timber) and opportunities to have better access to sawn timber as company vehicles would transport it for free to the village. Village leaders appreciated the system whereby the district government could issue licences, because the district government's office was relatively accessible (only two hours' drive from Sengayan), and community members were content with the benefits they received. Based on this positive experience, the village leaders of Sengayan sought to continue logging in the Sengayan village area under new forestry regulations. However, they did not wish to allocate all their land to logging. The forest upstream (approximately 6,000 ha) has been designated protection forest in the village's development programme to maintain a balance between areas exploited for timber production and forest areas providing other needs (e.g. game, rattan). 
Through on-going discussions with CIFOR, the villagers have gradually developed ideas for village landuse and forest management. They considered factors such as accessibility, potential for resource extraction by villagers, subsistence use, watershed protection and commercial exploitation. More recently, in 2004, they envisaged four more-or-less equally sized $( \pm 3,000$ ha) forest categories: (i) production forest for commercial exploitation either by a company or community members, (ii) village forest (hutan kas desa) for noncommercial exploitation by community members (including timber), (iii) protected forest and tourism/recreational forest where no timber may be cut, and (iv) forested areas for expansion of agricultural land, e.g. to establish rubber plantations.

Presently the community is considering selling sawn timber in Malinau town. The villagers anticipate that, due to the changes in forestry and decentralisation laws, it will take some time before a logging company can operate in their territory. A temporary alternative would be to saw timber using chainsaws and supply the timber demands of the rapidly expanding district capital. However, they are hesitant to start these activities as it might be difficult to obtain the necessary papers to sell the sawn timber.

Satellite imagery showed that the forest of Sengayan is relatively undisturbed while the survey showed the presence of large trees of more than $40 \mathrm{~m}$ in height with a diameter at breast height $(\mathrm{dbh})$ over $200 \mathrm{~cm}$. The mean density of trees with a diameter over $20 \mathrm{~cm}$ per hectare is 262. The forest is dominated by keruing (Dipterocarpus sp.) and ironwood (Eusideroxylon zwageri). Except gaharu, which has been considerably over-exploited, there are non-timber forest products in abundance. However, unsustainable practices, such as cutting trees to harvest fruits, have caused the scarcity of some fruit trees previously more abundant. These are now found only in less accessible locations.

\section{FOREST INVENTORIES AT SETULANG AND SENGAYAN}

\section{The process}

In 2004-5 we conducted forest inventories around the two villages using systematic strip sampling. The strips were $20 \mathrm{~m}$ wide, situated approximately $1.5-2.0 \mathrm{~km}$ apart, and were of variable length depending upon local topography and the size and shape of the forest area. A total of $24.9 \mathrm{~km}$ was sampled at Setulang and only 4 $\mathrm{km}$ (due to a lack of interest by the community) in Sengayan.

The forest inventory was identified as a key step in providing information for the planning process. However, during its implementation, it became clear that there was a difference in interest and understanding of the potential use of the forest inventory between the village leaders and the community members involved in the inventory.

In Setulang community leaders and members showed great interest in the inventory, particularly as a tool for them to be better able to describe the richness of the Tane' Olen forest. The inventory was not essential for the planning phase, as the Setulang community had already decided upon the establishment of the Tane' Olen. However, it increased the community's appreciation of the intrinsic value of the forest in the Tane' Olen, and for example stimulated the people to try to find trees with even greater diameter than the $398 \mathrm{~cm}$ record diameter encountered during the inventory, an individual of Shorea sp. Some of the results of the inventory also surprised the community, notably that ironwood (Eusideroxylon zwageri) is among the most common tree species.

The village leaders of Sengayan appreciated the forest inventory especially as a potential tool for better management of the production forest. Accurate information on the timber potential and areas with protected species is important for the communities to be better equipped to negotiate with logging companies, e.g. regarding potential volume that can be extracted and 
areas that should not be exploited. However, as no logging has yet occurred, the value of the information to the villagers' negotiations with logging companies has not yet been appraised. The community members involved during the inventory did not seem to consider the data from the inventory as important for the future development of their village, as they are less involved in the negotiation process between communities and logging companies.

\section{Dominant species and timber}

\section{Setulang}

Tree species diversity is high, with almost 300 species found, dominated by red and white meranti (Table 1). Large trees of more than $40 \mathrm{~m}$ tall with a diameter over $200 \mathrm{~cm}$ are common in the primary forest. The largest individual tree we found was a betey (Shorea sp.) with a diameter of $398 \mathrm{~cm}$. Other large trees were mainly of majau (Shorea johorensis), one of which had a $\mathrm{dbh}$ of $223 \mathrm{~cm}$. Our inventory, sampling at 1\% intensity, showed an overall density of 200 trees with a diameter over $20 \mathrm{~cm}$ per hectare.
The most important non-timber forest product (NTFP) is tengkawang fruits (primarily from Shorea macrophylla and S. beccariana) found scattered more or less evenly throughout the area. Other NTFPs are rattan, fruit, sang leaves (Licuala valida), vegetables and medicinal plants. Over the past couple of years, gaharu has been exploited on a large scale throughout the wider region, including in this area. There is relatively good regrowth, although there are clear signs of young trees as small as $5 \mathrm{~cm}$ in diameter having been cut.

\section{Sengayan}

At Sengayan the two most common species were keruing (Dipterocarpus sp.) and ironwood (Eusideroxylon zwageri) (Table 2). The results from Sengayan illustrate the strong desire of the community to be involved in timber extraction. They have considered several alternatives that could provide them with a substantial source of new income. Logging companies would manage harvesting, while the community would monitor logging practices. Community members could make use of timber resources in other parts of

Table 1. Indicator of importance for 10 of the most important trees in the forest of Tane' Olen, Setulang village

\begin{tabular}{|c|c|c|c|c|c|c|c|c|}
\hline \multirow[b]{2}{*}{ Latin name } & \multirow[b]{2}{*}{ Local name } & \multicolumn{3}{|c|}{ Absolute: } & \multicolumn{3}{|c|}{ Relative (\%): } & \multirow{2}{*}{$\begin{array}{c}\text { Import- } \\
\text { ance } \\
\text { score }\end{array}$} \\
\hline & & $\begin{array}{l}\text { Density } \\
\text { (Iha) }\end{array}$ & Freq. & $\begin{array}{l}\text { Domin- } \\
\text { ance }\end{array}$ & Density & Freq. & $\begin{array}{l}\text { Domin- } \\
\text { ance }\end{array}$ & \\
\hline Shorea sp. & $\begin{array}{l}\text { Meranti Merah } \\
\text { (Kaze Tenak Bala) }\end{array}$ & 13.5 & 0.36 & 4.7 & 6.8 & 2.6 & 11.2 & 20.5 \\
\hline Shorea sp. & $\begin{array}{l}\text { Meranti Putih } \\
\text { (Kaze Tenak Futi) }\end{array}$ & 16.1 & 0.36 & 4.2 & 8.0 & 2.6 & 9.8 & 20.5 \\
\hline Shorea johorensis & Majau (Kaze Ayi) & 7.0 & 0.33 & 3.3 & 3.5 & 2.4 & 7.9 & 13.7 \\
\hline $\begin{array}{l}\text { Eusideroxylon } \\
\text { zwageri }\end{array}$ & Ulin (Bele'em) & 10.3 & 0.34 & 2.4 & 5.1 & 2.4 & 5.7 & 13.2 \\
\hline Shorea sp. & Tengkawang & 7.4 & 0.32 & 2.2 & 3.7 & 2.3 & 5.1 & 11.1 \\
\hline $\begin{array}{l}\text { Madhuca } \\
\text { spectabilis }\end{array}$ & Kajen Ase & 9.6 & 0.32 & 1.1 & 4.8 & 2.3 & 2.5 & 9.6 \\
\hline Dipterocarpus sp. & $\begin{array}{l}\text { Keruing (Apang } \\
\text { Lareny) }\end{array}$ & 5.8 & 0.32 & 1.7 & 2.9 & 2.3 & 3.9 & 9.1 \\
\hline Myristica sp. & $\begin{array}{l}\text { Darah-darah (Kaze } \\
\text { Nyera'a) }\end{array}$ & 6.9 & 0.42 & 0.7 & 3.4 & 3.0 & 1.7 & 8.1 \\
\hline Dryobalanops sp. & Kapur (Kafun) & 3.5 & 0.25 & 1.5 & 1.7 & 1.8 & 3.5 & 7.0 \\
\hline Shorea sp. & $\begin{array}{l}\text { Meranti Kuning } \\
\text { (Kaze Tenak Mic) }\end{array}$ & 2.1 & 0.19 & 1.8 & 1.0 & 1.4 & 4.2 & 6.6 \\
\hline
\end{tabular}

Frequency: number of plots where a particular species is found/total number of plots Dominance: basal area of a species/total area of plots Importance score $=$ sum of relative percentages 
Table 2. Indicator of importance for 10 of the most important trees in the forest of Sengayan village

\begin{tabular}{|c|c|c|c|c|c|c|c|c|}
\hline \multirow[b]{2}{*}{ Latin name } & \multirow[b]{2}{*}{ Local name } & \multicolumn{3}{|c|}{ Absolute: } & \multicolumn{3}{|c|}{ Relative (\%): } & \multirow{2}{*}{$\begin{array}{c}\text { Import- } \\
\text { ance } \\
\text { value }\end{array}$} \\
\hline & & $\begin{array}{c}\text { Density } \\
\text { (Iha) }\end{array}$ & Freq. & $\begin{array}{l}\text { Domin- } \\
\text { ance }\end{array}$ & Density & Freq. & $\begin{array}{l}\text { Domin- } \\
\text { ance }\end{array}$ & \\
\hline Dipterocarpus sp. & Keruing & 18.4 & 0.25 & 4.8 & 15.9 & 5.3 & 14.9 & 36.1 \\
\hline $\begin{array}{l}\text { Eusideroxylon } \\
\text { zwageri }\end{array}$ & Ulin & 15.4 & 0.25 & 3.4 & 13.3 & 5.3 & 10.7 & 29.3 \\
\hline Shorea sp. & Meranti Merah & 8.6 & 0.25 & 4.6 & 7.5 & 5.3 & 14.2 & 27.0 \\
\hline Shorea sp. & Meranti Putih & 7.6 & 0.25 & 3.2 & 6.6 & 5.3 & 9.9 & 21.7 \\
\hline Parashorea sp. & Urat Mata & 3.6 & 0.23 & 2.6 & 3.1 & 4.7 & 8.0 & 15.9 \\
\hline Shorea sp. & Tengkawang & 6.3 & 0.25 & 1.6 & 5.4 & 5.3 & 4.9 & 15.6 \\
\hline Palaquium sp. & Nyatoh & 6.3 & 0.25 & 1.2 & 5.4 & 5.3 & 3.6 & 14.3 \\
\hline $\begin{array}{l}\text { Koompassia } \\
\text { malaccensis }\end{array}$ & Limpas & 4.5 & 0.25 & 1.6 & 3.9 & 5.3 & 5.0 & 14.2 \\
\hline Shorea sp. & Meranti Kuning & 4.8 & 0.25 & 1.4 & 4.1 & 5.3 & 4.5 & 13.2 \\
\hline Dryobalanops sp. & Kapur & 4.0 & 0.25 & 1.4 & 3.5 & 5.3 & 4.5 & 10.5 \\
\hline
\end{tabular}

Frequency: number of plots where a particular species is found/total number of plots

Dominance: basal area of a species/total area of plots

Importance score $=$ sum of relative percentages

the forest protected from commercial logging. The main obstacle they face is the uncertainty in policy and official decision-making, the lack of transparency and changes in forestry laws and regulations. Cooperation between the community and a logging company will need facilitation by the government to ensure transparency, accountability and adherence to forest regulations.

\section{Species and habitats requiring special protection or management}

As a whole, the area is species diverse (Table 3 ) and hence requires appropriate conservation and management measures. The total number of trees greater than $10 \mathrm{~cm}$ diameter in the 67 sample plots at Setulang was 1,153, representing 90 genera and 45 families. If all vegetation layers are included (trees, saplings and seedlings), there were 216 species belonging to 120 genera and 53 families. The situation in Sengayan is similar; in the 42 sample plots, 121 tree species were documented belonging to 74 genera and 38 families. Considering all vegetation, 205 species were found belonging to 105 genera and 47 families. These figures are higher than other forest inventories in Kalimantan, except for Apo Kayan (Table 4). However, the number of sample plots and hence total area sampled was also higher at Apo Kayan.

The forest areas of Setulang and Sengayan are also important for conservation purposes as they both harbour species that are either rare or susceptible to disturbance, such as the giant hemi-parasite Rafflesia sp. which is dependent on its host (Tetrastigma sp.).

Table 3. Numbers of families, genus and species of trees with a diameter $\geq 10 \mathrm{~cm}$ in a number of sites in Kalimantan

\begin{tabular}{lcccccc}
\hline \multirow{2}{*}{ Site } & Sample & \multicolumn{3}{c}{ Number of: } & \multirow{2}{*}{ Reference } \\
\cline { 3 - 5 } & area (ha) & families & genera & species & & \\
\hline Setulang & 0.67 & 46 & 90 & 157 & Sidiyasa et al. (2006) \\
Sengayan & 0.42 & 38 & 74 & 121 & Sidiyasa et al. (2006) \\
Sekadau, West Kalimantan & 0.6 & 37 & 71 & 106 & Sidiyasa (1987) \\
Wanariset Samboja, East Kalimantan & 0.51 & 35 & 76 & 117 & Valkenburg (1997) \\
PT. ITCl, East Kalimantan & 0.5 & 31 & 62 & 104 & Valkenburg (1997) \\
Apo Kayan, East Kalimantan & 0.8 & 42 & 78 & 175 & Bratawinata (1986) \\
\hline
\end{tabular}




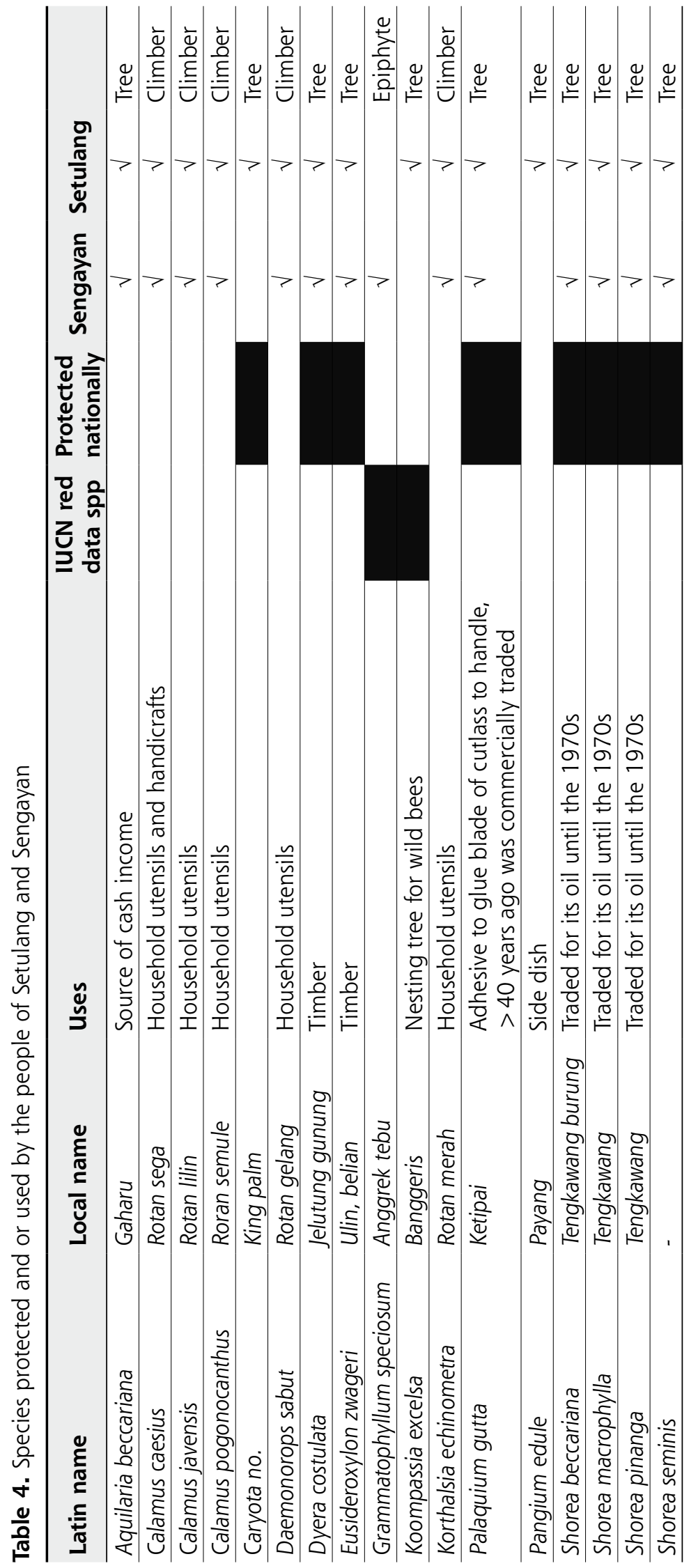


Three mechanisms were used to determine the conservation status:

- Reference to IUCN criteria as summarised in the national red data species inventory;

- Species protected according to government regulations; and

- Species protected because of adat or agreements by local people.

We observed at least 17 species protected and or frequently used by local people (Table 4). Three of the species mentioned in the table are classified as most endangered. These are Caryota no (king palm), Aquilaria beccariana (gaharu) and Grammatophyllum speciosum (sugar cane orchid). The last is a CITES Appendix II species. In addition, there are species much used by local people such as Licuala valida (sang, a palm, the leaves of which are used to weave hats and mats), Alocasia sp. (a forest yam used as vegetable), fruits, medicinal plants and others such as Duabanga moluccana, which according to a Minister of Agriculture Decree (SK Menteri Pertanian No. 54/Kpts/Um/2/1972) is a protected species that is abundantly found in open places such as along rivers and logging roads. Tree ferns (Cyathea borneensis and C. glabra) which are also listed on Appendix II of CITES) are also found here. According to information from local people, some highly utilised species are now scarce. These include Eugeissona utilis (sagu), Scorodocarpus borneensis (onion wood) and many species of orchid (Sheil et al., 2006).

Special habitats or sites requiring particular management or protection measures that were identified during the forest inventory and community meetings were:

- Habitat of the tengkawang and king palm (Caryoto no) because, as discussed above, these species existed in only very low densities (or just one individual) and with limited or no regeneration observed.

- Riparian vegetation due to special species that occur there, the need to stabilise stream banks and avoid contamination of the water.

- Special animal habitat, such as sites that pigs, deer and primates require for their foraging, nesting or other needs, and sites where they are found in high abundance for hunting, for example salt licks, pig wallows and large fruit trees (such as Dracontomelon dao, Shorea spp., Lithocarpus spp., Artocarpus spp. and
Ficus spp.) and others which provide forage for many animal species.

- Historical sites, especially grave sites. Close to the village of Sengayan, at the confluence of the Sengayan and Malinau rivers, is the site of old graves abandoned when the people were relocated in 1973. The graves are of two forms: (i) iron wood coffins supported by three pillars some $2 \mathrm{~m}$ above ground with each coffin containing one body. This form of cemetery is called 'mblieh'; (ii) a small shed with sloping roof similar to a rice barn made of ironwood with a roof made from zinc sheeting. These constructions might contain more than one body placed in coffins, and are named 'tanaw'. They are more recent than the 'mblieh'. According to old people of the village, this manner of traditional burial ended around 1968 when the people of Sengayan converted to Christianity.

\section{COMMUNITY-BASED VILLAGE LAND-USE PLANNING}

\section{The planning context and legislation}

In Indonesia laws and regulations concerning land-use planning (Undang-undang No. 24/1992 and Permendagri No. 9/19988) specify mechanisms for community input (see Warta Kebijakan No. 5 on Spatial Planning). In principle, during each phase, a public announcement has to be made to solicit their contributions, and communities have the right to give a variety of types of input.

Beside the legal requirements, the change in political climate since the fall of the Soeharto regime (known as Reformasi) has provided new possibilities for community involvement in public affairs, including land- use planning. In addition, regional autonomy aims to increase the responsiveness of local government to local conditions and needs. These conditions should provide ample space for communities to influence the land-use planning process.

The district government of Malinau, established in 1999, was keen to revise the existing landuse plan to reflect changing conditions and 
accommodate new development plans. As Malinau is sparsely populated and still has extensive areas of primary forest, the opportunity for rational planning and implementation was high. As the dispersed communities are still highly dependent on a wide variety of natural resources from forested areas, they can be seriously affected if large-scale development activities are not planned appropriately.

\section{The Approach}

Initially we used participatory mapping to clarify boundaries and help to resolve conflicts when possible. Thereafter, through visioning and small group discussions, community members reflected upon the present resource and land use and debated needs and options for the future. Additionally, in the case of Sengayan, two community members participated in a cross-visit to enrich ideas for potential economic activities and related future land use. Discussions on future land use, both formal and informal, were conducted over a one-year period. Then a small village committee finalised the landuse planning and produced a land-use map at each site. A third village, Pelancau, which had initially participated in the project, was reluctant to produce a map because of a landtenure conflict with the surrounding villages and withdrew from project activities.

In developing their land-use plan, the communities considered the present conditions and the potential of various parts of their village area. Information on and awareness of resource potential was increased through the forest inventories presented above. In discussions, community members were encouraged to consider several options for future developments. Community members combined opportunities (e.g. plan to develop oil-palm plantations) known through previous experience (e.g. work in Malaysia) with estimates of best future choices to guide the development of their land-use plan. After defining their priorities, communities linked their vision to a map.

Management options and regulations were considered once use categories were assigned. Indeed, once the use categories were agreed, communities tended to stick to them, but continued discussion about management of various categories or possible opportunities for development activities with the agreed use categories. Both in Sengayan and Setulang, villagers continued to discuss whether and which tree crops should be planted in the designated area assigned for cash crops. These discussions included experiences of individuals within the community as well as their assessment of government programmes, such as gaharu and teak planting under the district reafforestation programme and oil palm, acacia and rubber which are planned for plantation development. In fact, most villages are quite willing to incorporate government plans for plantations provided they are in locations around the village that they, the villagers, specify. Over the past year, government plans threaten to disrupt community planning, and this uncertainty has led to reduced interest in the land-use planning process itself. Nevertheless, the village head of Sengayan recently reaffirmed his commitment to the land-use plan.

The maps produced showed general land-use categories that could easily correspond to official categories at the district or national level, such as protected forest and production forest. There is a need, however, for designating at the district level the forests which can be used for swidden agriculture. The designation of areas is left purposely at a broad scale, as too much detail would be burdensome to district officials and beyond the planning needs of the community at this stage. The maps of land-use plans for each village were posted throughout the village and were also sent to the district government.

\section{Setulang Village Land-use Plan}

\section{Zoning categories}

Discussions in Setulang focused on the need for land for present and future generations and its potential. This resulted in designating four different land-use categories and agreed spatial zones:

\section{- Upland farm land}

Upland rice is the mainstay of people in Setulang and comprises the majority of the current intensively used areas. The land-use plan assigned these areas for continued upland rice cultivation. This includes old fields as well as land in use at the present time. Within this 


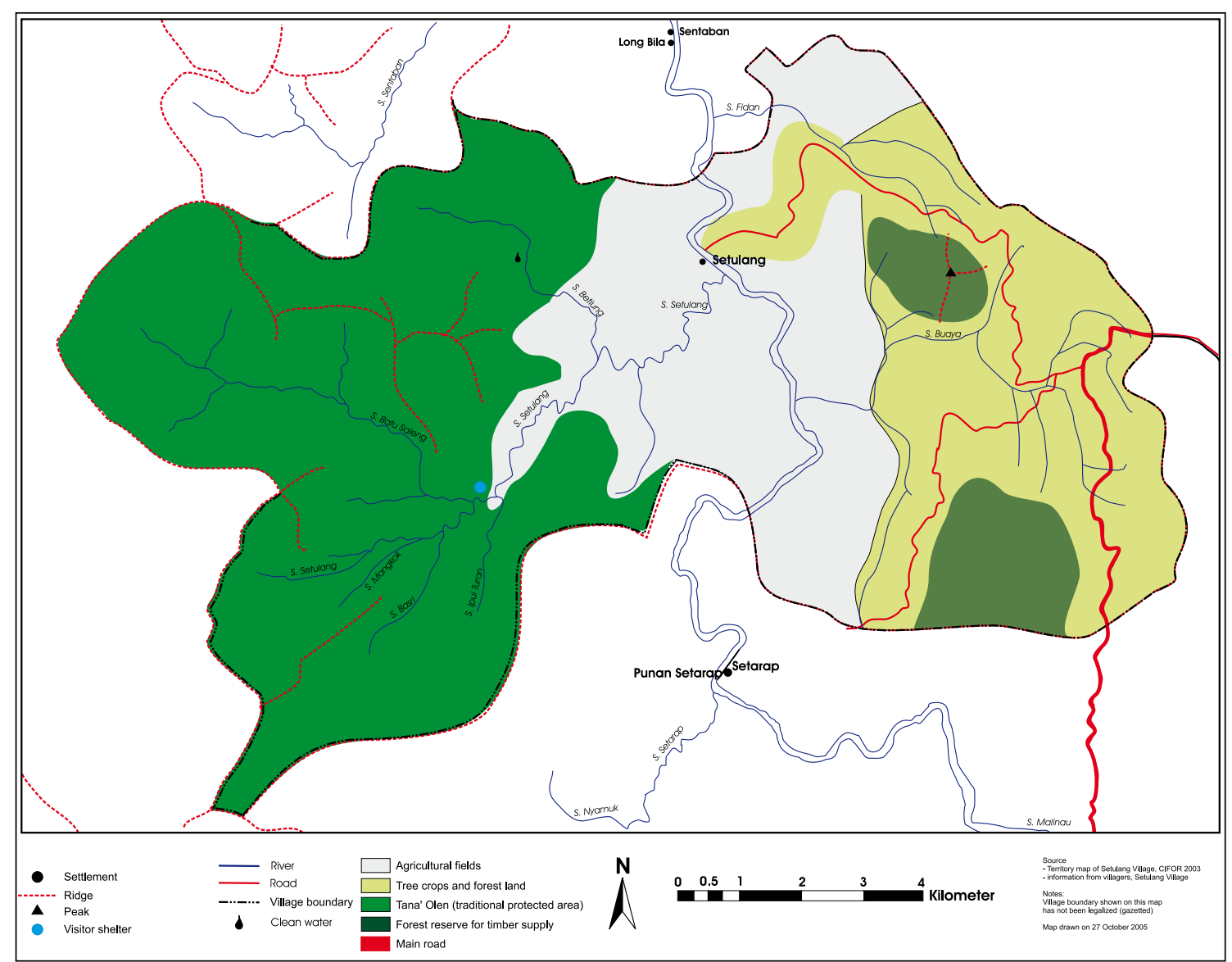

Figure 1: Setulang Village Land Use Plan 2005

area, some parts are suitable for development of irrigated rice cultivation (some areas along the Buaya River, Betiung River and Merotok River).

\section{- Tane' Olen (protected forest)}

The designation of Tane' Olen protected forest $(5,300$ hectares), as explained earlier, was based on observations on the impacts of logging and experience from working in Malaysia. It has led to the initiative of designating a forest conservation area. Based on community consensus and the relatively intact forest in the upper Setulang, the area was declared a Tane' Olen in 2002.

\section{- Forest reserve}

Two portions within the Setulang territory, totaling 500 ha, were designated as reserved forest ${ }^{1}$. These are areas with remnants of forest and limited agricultural potential due to steep slopes and thin soils with many rocks. Currently these areas are not used for agriculture. They have been set aside especially to provide timber needed for local construction. Their proximity to roads was a key factor in assigning these areas as forest reserves so that transport of sawn timber will be relatively easy.

\section{- Tree crop area}

Approximately 1,000 ha located along the roads within the Setulang village territory (PT Inhutani II main road and the SetulangSetarap access road) were assigned for tree crop development. It is expected that transportation of the produce from the tree crop plantations will stimulate the much-needed road maintenance. After some village leaders undertook a trip to visit oil-palm plantations

\footnotetext{
1 These forest reserves have no legal status. However, the criteria used by the community and the physical condition of the area match with the legal criteria used to assign forest reserves (known as Hutan Lindung in the Indonesian forestry law).
} 
in Sabah, Malaysia, the area assigned to oil palm was increased. If government-sponsored oil-palm plantations are to be established, it is expected that this will happen within this designated area. However, some farmers have already stated that they are more interested in developing other tree crops rather than oil palm in this area.

\section{Regulations for each land-use category} Having agreed the types and spatial zoning of the different land uses, it was agreed to consider management options, as well as rules and regulations guiding uses within each zone.

\section{- Upland farm land}

As upland rice farming is the most common traditional use, regulations are well established and based on customary rules. An important rule is that fields be located near each other to enable communication in case of emergencies. The location for next years' fields is discussed and allocated during the yearly harvest festival. Custom also dictates that most people will leave quality timber trees in their fields for future construction needs. As is common throughout the region, ownership of farm land is based on the principle of 'merimba2', which allows borrowing by others but prohibits the planting of perennial crops. In addition, after the designation of Tane' Olen, people are advised not to plant rice in fields bordering that area.

\section{- Tane' Olen}

For the Tane' Olen, the people of Setulang had already developed a set of written rules for its management, contained within the general customary rules regarding resource use:

a. Only timber for construction of public-use buildings can be extracted from Tane' Olen

b. Hunting is allowed provided it is not excessive

c. People from other villages have to ask permission before entering Tane' Olen

d. Nobody from outside Setulang is allowed to collect forest products

e. Poisoning and electro-fishing is prohibited

f. Felling of fruit trees is prohibited

${ }^{2}$ The principle behind marimba is that the person who clears a plot of primary forest obtains ownership over that plot. This ownership is subsequently extended to his/her descendants. g. People are not allowed to claim trees by marking the stem with their name

h. People cannot individually claim fruit trees

i. It is prohibited to clear land for upland rice fields

j. Tane' Olen is not open for exploitation by investors, even in cooperation with the community

Along with these rules, the community had agreed a set of sanctions for people breaking the rules. However, nobody has as yet been penalised. There have been signs of outside people entering Tane' Olen in search of gaharu but they are seldom caught and when they are, they have merely been requested to leave the area immediately with no fine imposed. The agreed sanctions were:

a. 50\% of sawn timber for sale cut in Tane' Olen will be confiscated

b. Work and transport equipment of anybody felling trees in Tane' Olen for the sale of logs will be confiscated

c. Fine for felling trees Rp 100000

d. Fine for felling petai (Parkia sp.) or durian (Durio sp.) Rp 500000

e. Fine for felling other fruit trees Rp 200000

\section{- Forest reserve}

The forest reserve is intended to fulfil the future need for timber for public use only. Individual use is expected to be fulfilled from the trees left on individual upland rice fields. Although already firmly designated, no specific rules have been established so far, although discussions continue. The only general rule is that people are not allowed to clear plots of forest for upland rice in the forest reserve area.

\section{- Tree crop area}

Like almost all farmers along the Malinau River, people in Setulang are eager to develop more plantation crops for cash incomes. Farmers have shown interest in several species, including teak, oil palm, cempedak (Artocarpus integer), gaharu (Aquilaria sp.), local fruit species, and payang (Pangium edule). However, other than the zoning, so far no explicit rules have been formulated. Indeed, currently, the decision on which species of tree crop to develop has been left to the individual farmers. One problem that has not been solved is the distribution of plots in this area, as not all farmers own land in this area. 
One proposal under discussion is to swap land to enable all villagers to participate in tree crop development.

\section{Implementing activities}

As a firstaction, the people of Setulang established a management board which is responsible for implementing the zoning plan and regulations in accordance with the different management goals of the plan and for the different land-use zones. Clearly this will take time, and needs to be dynamic, i.e. constantly updated as conditions change and specific opportunities evolve or are constrained.

\section{- Activities planned for development of Tane'} Olen so far include

a. Placement of boundary signs along the village boundary at the end of each transect of the forest inventory

b. Placement of poles marking each inventory transect at the riverside

c. Search for trees with diameter over $3 \mathrm{~m}$ (the largest diameter found during the inventory)

d. Development of tracks for visitors to Tane' Olen

\section{- Tree crop development}

a. A reafforestation programme in the Fidan River area with mahogany and gaharu, which is part of the government-sponsored reafforestation programme. Individual plots of farmers will be measured before planting is started. This will provide information for the inventory of agricultural land

b. Inventory and (sketch) mapping of all agricultural land

c. Develop list of criteria to be fulfilled by any investor for cash crop development (including issues of land tenure, benefit sharing and land allocation)

While these plans have been made and accepted by the community, implementation moves slowly. The new village head who also sits on the management board is concerned that without actions the community might lose interest. He is now considering how to initiate more economically focused activities which will raise some funds for the planned activities in the conservation area.

\section{Sengayan village land-use plan}

\section{Zoning categories}

Based on the existing potential and the need for land for present and future generations, the people of Sengayan assigned eight different land-use categories:

\section{- Upland farm area}

The area for upland rice cultivation consists of old and current fields around the old settlement, at the confluence of the Sengayan River with the Malinau River. This area is easily accessible and large enough to accommodate the present and envisaged future need for land.

\section{- Irrigated rice cultivation area}

Within the current areas of rice cultivation there are some parts, especially along the riverbanks of the Sengayan and Malinau rivers that are relatively flat and where small streams could be used for irrigation. So far these areas have not yet been developed, but the people expect that in the future irrigated rice cultivation will be developed here.

\section{- Settlement}

The village of Sengayan is part of the Loreh settlement with facilities such as an elementary school and a junior high school, a health clinic, meeting hall, churches and a mosque. In the surrounding areas of the present settlement, sufficient land is available to allow for future expansion.

\section{- Tree crop area}

One part of the village territory that is presently used for upland rice and some tree crop gardens has been designated for the cultivation of tree crops. At the moment transport to this area is by boat, but the neighbouring coal-mine is planning to construct a bridge across the Malinau River, which will facilitate road transport. Transport is also a major consideration in the discussion about which tree crops to develop. Many people of Sengayan favour establishing rubber gardens because transportation of the produce is relatively easy and can be undertaken via both road or river (if the construction of the bridge is delayed or abandoned). 


\section{- Production forest}

A production forest of 3,200 ha was designated in an area with high timber potential and where there is already a road network developed by the IPPK company. The people of Sengayan envisage that exploitation of the production forest will be done in cooperation with a logging company. To this end, the village head has been seeking potential investors. One problem Sengayan faces in implementing the plan to exploit the production forest is the limited size of the area, making it unattractive for commercial exploitation by a logging company, unless it is combined with forest from neighbouring villages. Currently there is considerable discussion centred around a government plan to allow industrial acacia plantations in this area. The village is considering allowing planting only in their designated production forest areas but is concerned that they will not have any say over the planning.

\section{- Community forest (hutan kas desa)}

Community forest is designated to provide a range of forest products for daily use, and includes a stand of valuable Agathis trees that are still relatively easy to access on the lower parts of the Sengayan River.

\section{- Protected forest and recreational forest}

Protected forest and recreational forest were assigned to the most remote areas of the Sengayan village territory. The recreational forest is near the site of a hot-water spring and the forest is still intact. Travelling to this area is by boat and is time consuming (almost one day depending on the water level), but this could probably be reduced to two hours if road transport can be developed.

\section{Debates around implementing the zoning plan}

\section{- Upland rice areas}

Regulations for the upland rice cultivation area are based on customary rules that are still adhered to by the people of Sengayan. Within the area assigned for upland rice cultivation, every farmer is allowed to open up new land (i.e. clear primary forest) based on their needs and capacity. The need to discuss whether they want to limit the maximum size an individual is permitted to clear has been raised, but the discussion has not yet taken place. The motivation is to prevent more affluent people from controlling large tracks of land. The ownership of farm land is based on the principle of 'merimba', as

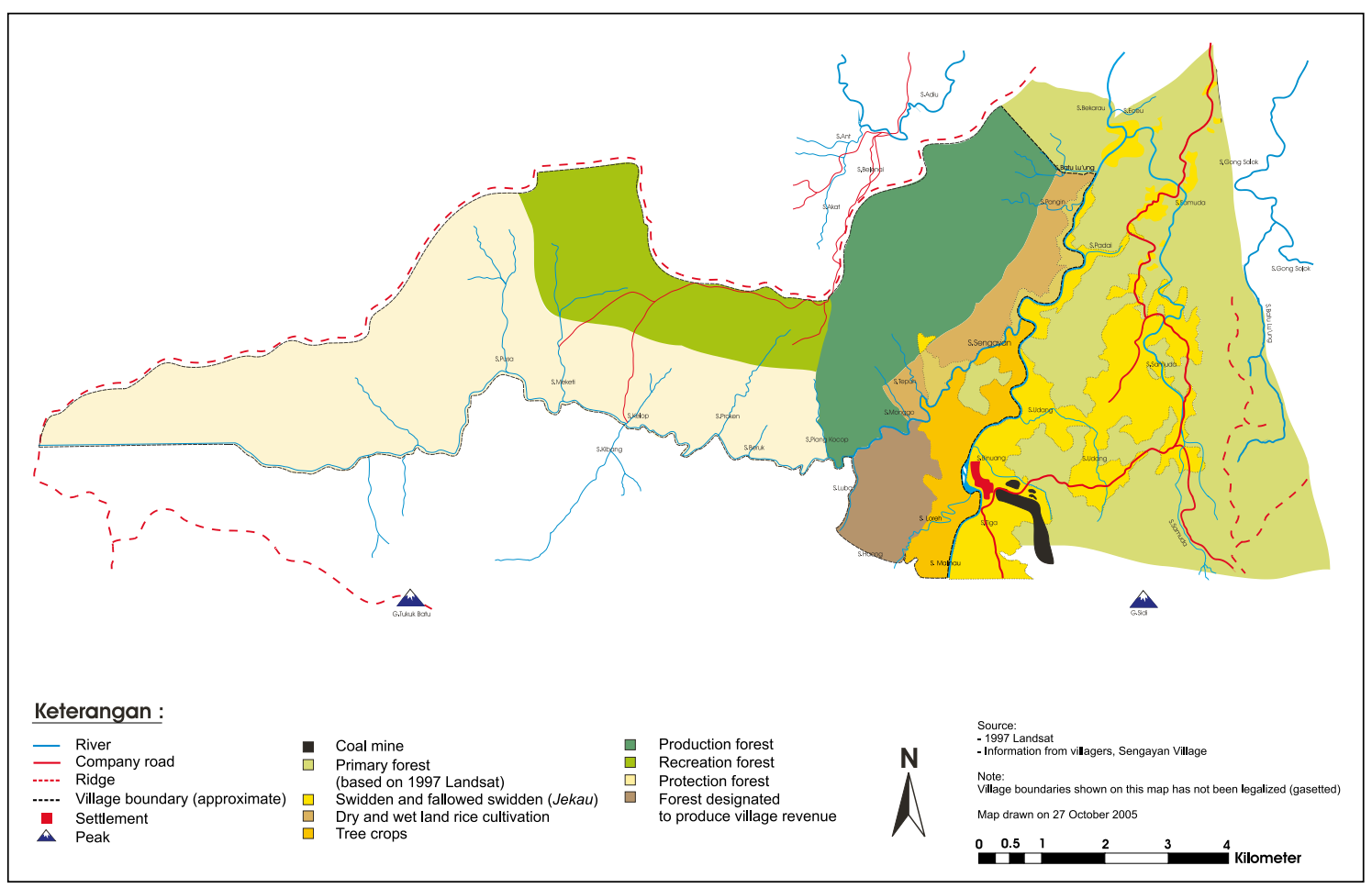

Figure 2. Sengayan Land Use Plan, 2005 
described above. This ownership is inherited by his/her descendants, and it is increasingly possible for the plot to be sold. Other farmers are allowed informally to borrow that plot of land after obtaining prior permission from the owner. The farmer borrowing a plot of farmland is not allowed to plant perennial crops.

\section{- Irrigated rice lands}

The development of irrigated rice cultivation is a long-term vision of the residents of Sengayan. They recognise that not all land within the area assigned is suitable for irrigated rice cultivation and equally that there is some land outside this area that can be developed for this purpose. The establishment of irrigated rice fields is left to the initiative of individual farmers, although people hope for assistance from the government or from logging companies as part of communitydevelopment projects to build the infrastructure required for irrigation.

\section{- Tree crop area}

Within the community of Sengayan there are two visions on how to establish commercial tree crop plantations (e.g. oil palm, acacia or rubber). One is that the total area for cash crop plantation is developed collectively (or undertaken by labourers paid by an investor) and the net profit is shared equally amongst the people of Sengayan. Alternatively, the area will be divided equally per family and developed by individual families. With regard to the second method, special attention would be given to address land ownership issues, since individually owned plots are scattered throughout this area. The idea is that, if the land is divided equally amongst all families, no compensation payments will be made if the division of plots does not exactly match prior land ownership.

The people of Sengayan wish to cooperate with an investor directly after the investor has obtained the necessary permits from the government. Cash-crop development is planned only for areas presently used for farm land as the people of Sengayan fear that if areas of timber-rich forest are assigned for cash- crop development the investors will only take out the timber and not make a serious effort to establish cash crops. Some community members recognise that in principle they could develop cash crops independently if they cooperate closely. However, the majority of the people tend to depend prefer cooperation with an investor.
Given the choice to decide which cash crop to establish, the people of Sengayan prefer rubber, since the marketing of rubber does not depend on one company alone. The labour involved is relatively light (women and children can tap rubber), and transporting the produce is relatively easy. If the choice is between acacia and oil palm, they prefer oil palm as it starts producing earlier. However, people tend to wait and expect a third party to assist with the establishment of tree crops and provide a market.

\section{- Production forest}

The preferred management system for exploitation of the production forest is selective logging. However, the villagers are against the post-logging treatment of undergrowth slashing to promote regeneration because the complete clearing of undergrowth has a negative impact on the availability of various NTFPs collected by local people. It is also suspected that clearing of the undergrowth decreases the abundance of bearded pigs, due to their increased visibility to hunters.

To date, Sengayan's production forest has not been exploited by a logging company. In the meantime, the people of Sengayan cut timber for sale themselves using chainsaws. In principle there is no limit to the amount cut, but the chainsaw operators are obliged to pay a fee to the village. (The fee level per $\mathrm{m}^{3}$ has not yet been decided.) The people of Sengayan are concerned that the sale of sawn timber to Malinau Kota will be difficult as it is necessary to obtain official documents from the district forestry service. They expect that it is more realistic to sell locally in Loreh as there is less enforcement of forestry restrictions. However, the demand for sawn wood in Loreh is limited. People from other villages are not allowed to cut timber in this area. One concern is that the government plans for acacia plantation development in the area they assigned as production forest are an excuse to exploit the rich timber resources.

\section{- Community forest}

Community forest (Hutan kas desa) is assigned to supply forest products needed by the community, including timber. Its use is restricted to daily use, and commercial use is prohibited, especially where timber is concerned. Plans to link community forests to the reforestation fund $^{3}$ programme have been difficult as the programme is too rigid to allow variations. The 
species promoted through the programme are seldom based on people's preference and, as in the case of teak, often proves to be unsuitable to local conditions.

\section{- Protected and recreation forest}

Protected forest has an important role in watershed protection (similar to the official government category of protected forest), and thus no felling of timber is allowed. Presently this area is used for hunting, and people from other villages search for gaharu in this area. Timber extraction is also prohibited in the area assigned as recreational forest, where a main attraction is a hot-water spring and a nearby waterfall (close to the Adiu village territory). This could result in cooperation between the two villages as the previous village head of Adiu also showed an interest in promoting tourism in and around Adiu. In mid-2005, the community constructed a small shelter which they use during trips into the area. It is envisaged that in the long term visitors will be asked to make a payment to enter this area. To improve transport, road access is necessary, which can be achieved by repairing the ex-PT Barito road, which will require an external agent for assistance.

\section{CONSIDERING THE PROCESS OF COMMUNITY-BASED LAND- USE PLANNING}

Based on the process adopted during the course of this work, and our experiences at Setulang and Sengayan, a number of important lessons have emerged, which will be of use in future initiatives in similar regions as devolution of certain powers and responsibilities to local level continues throughout the region.

\section{Some basic principles for integrated land-use planning in remote areas}

Land should not be perceived as a resource to be developed and used for economic purposes only. Land- use planning must consider land as

\footnotetext{
${ }^{3}$ Reforestation funds are collected by the Ministry of Forestry to support reforestation. Since 2002 the Ministry of Forestry directly provided reforestation funds for reforestation plans submitted to the district government.
}

an asset to be maintained and improved for the well-being of present and future generations, as an essential part of the political, social and cultural fabric and of ecological balance. Land is the primary asset of the forest communities and needs to be used sustainably and equitably.

The regional and national context must be supportive of local level planning and management. Currently, the law in Indonesia provides for public participation in four stages where the government is required to announce its intentions continuously over a seven day period and allow30 days for a response. Participation can be organised through organisations such as multi-stakeholder boards, community boards, government representatives in the villages, Village Board of Representatives (BPD) and District Parliament (DPRD), NGOs, etc.

Contrary to a popular belief in matters of landuse planning, for a given land unit there is not a single optimal land use (however identified). All units of land possess particular characteristics, which may promote or hinder certain land uses. Inventory and evaluation of the potential of each land unit can provide information on limitations to certain types of use. It is important to note that the final restrictions and designations are a subjective, but hopefully informed, choice, which is made based on a host of different criteria, including qualitative ones such as local politics, history and taboos, all within the broader context of prevailing, but often changing, government regulations and incentives. Therefore the whole process must involve all the relevant stakeholders from the start. Communities should not just be consulted on the land-use planning decided at a higher government level; they must be involved in the planning and decision-making process.

Technological advances have facilitated considerable progress in the development of local-level databases on land resources and land use, in processing and integrating information from multiple sources (environmental, social and economic), and in developing more effective analytical and planning tools. Mechanisms and tools have been developed to make integrated information systems more accessible, facilitating the involvement of multiple stakeholders at different levels of planning and management. These include increasingly user-friendly GIS 
software, coupled with increasingly cheaper and better GPS units.

The rights of all stakeholders should be established fairly and recognised both legally and by all other stakeholders. In particular, spatial/land-use plans will be more secure if ownerships and land rights are clear. When ownership is clear, it becomes easier to assign management responsibilities to parcels of land. In addition, the public has the right to be informed on rights in spatial/land-use planning. Therefore land-use planning needs to be preceded by clear boundary demarcation of the different level administrative sub-divisions: village within sub-districts within the district. As yet there is also no clear demarcation between private and state land.

Zoning should be based on a sound scientific approach after appropriate inventories have been carried out. The criteria for the delineation of specific zones should include non-use values and functions of forests. Forest zoning should be carried out using an approach that is transparent, responsible, collaborative and participatory, involving all existing multi-stakeholders in the region. There should be clear delineation of forests directly controlled by the state (including customary forests managed by communities, hutan adat) and forests owned by individuals (or communities). The delineation of forest zones on the ground should be clear and agreed upon by all stakeholders.

The participation and support of local people are required in the spatial planning process. From a practical point of view, it is better to involve stakeholders at the beginning. Participation can aid agreement making and prevent conflict, provide information on land suitability and build understanding and support between people and government. A plan must coalesce from trade-offs, and these trade-offs require careful consideration of people's concerns and ideas. However, the potential benefits (and costs) to participants need to be fully articulated, as a means of building trust, but also enthusiasm for the participation process (e.g. Dolisca et al. 2006). This requires an open flow of information within and between different stakeholder groups and planning hierarchies.

\section{POTENTIAL OBSTACLES TO COMMUNITY-BASED LAND- USE PLANNING}

\section{Community interest in land-use planning}

Experience with IPPKs has resulted in an increasing desire of communities to be involved in management of forest resources in their area. In CIFOR-facilitated workshops, community representatives stressed the importance of balancing utilisation and conservation. On the other hand, livelihood patterns are changing and there is an increased interest in cash income, ownership rights over land rather than use rights, and an increased dependence on possible support from third parties. There seems to be a sense of futility in long-term planning.

In discussion with villagers, it became apparent that the rationale behind the long-term benefits of well-managed forests was not sufficient incentive for realistic planning. It might be that people here are used to boom/bust cycles, and despite the IPPK bust they are confident of a boom to come. Indeed there are already signs of a second wave of forest exploitation which might bring in another increase in cash income.

Long-term planning also requires leadership and trust. The IPPK experience, with its resulting competition for immediate gain, has greatly reduced any existing trust. As a result, few communities show the cohesion necessary to build trust in each other and in their collective capacity for planning. Within communities it is difficult to include weaker groups in the process (e.g. women, poorer community members). Attention has to be given to ensure that these weaker groups have channels to provide input in the process if they wish. It should be recognised that the interest within communities to be involved in the planning process differs: some people only want to be informed about the existing land-use plan, while others want to participate from the information-collection phase and in the discussions about land-use options. It does not help that the government is making land-use plans independently of village land-use planning and that on top of that, the central government issues permits for 
logging and or plantation development without informing the local population.

Discussions also show that while villagers are willing to contribute to land-use planning they expect others to implement them. Thus there is the expressed hope that government, but mainly incoming companies, will build roads, irrigation systems, clean water supply systems and even plant the trees on farmers' fields as part of the plantation schemes.

\section{Security of tenure}

Another problematic aspect is that land and resource tenure for communities in Malinau, as in most of Indonesia, is still uncertain. Weaker groups (e.g. the Punan) are hesitant to put forward strong claims, and they give in more quickly to claims made by other groups. Close connections between the local elite, local entrepreneurs and government officials have enabled some groups or individuals to obtain large benefits which they use to try to strengthen further their claims. These claims overlap with village territories, thus further undermining communities' certainty of access to land or resources.

Boundary disputes and overlapping resource use are issues complicating inter-village cooperation. So, simultaneous to developing land-use planning, the district and national governments need to address issues of land and resource tenure.

Consequently, communities are hesitant about planning detailed use categories or planning too far ahead. By designating general categories such as area for cash crop or community forest with some general management rules, communities maintain the flexibility to adjust to opportunities as they occur, such as government programmes or cooperation with the private sector.

\section{Obstacles to community-based initiatives}

In summary, obstacles to community forestry exist at several levels. Strengthening community forestry would require addressing these obstacles. At the village level, communities face:
- Weak village institutions

- Poor models for benefit sharing

- Lack of effective conflict management

- Poor markets, lack of market information and the disadvantage of high transport costs

- No access to equipment

- Weak recognition and linking of community rules and regulations to local government framework

- Unclear boundaries and land tenure

- Lack of knowledge of forest management

At the district government level, the main problems are:

- Limited experience and technical know-how, with different models of community forestry

- Development of community forestry is labour intensive and time-consuming for the forestry service

- Community forestry is more difficult to scale up

- Uncertainty about the legal framework regarding tenure, forestry and taxes and the implications for access and control over forest land

- Competing land uses that have higher potential for district revenue generation

- Large, remote areas that are difficult to survey

- Uncertainty about how to integrate community forestry with current land-use designations

At the central government level the main problems are:

- How to develop regulations that ensure sustainability, but are flexible enough to allow local adjustment to varying conditions

- How to develop mechanisms for appropriate taxation and benefit-sharing for different options

- How to control and monitor the implementation of regulations

NGOs could provide important assistance but face constraints such as:

- Development of community forestry is labour- and facilitation-intensive

- How to mediate between communities and district government

- How to translate experiences elsewhere to locally appropriate options

- How to avoid dependency of community on NGOs 


\section{Lessons learnt}

Although we have shown that there can be many types of community-based planning and forestry, there are some common features that are generally applicable. We suggest the following steps as important starting points:

- Acknowledge and protect existing users and their priorities, especially for meeting basic food and cash needs

- Start with small-scale experiments

- Communities have to be equal partners in the process, or they have to drive the process to ensure ownership and good communication

- Focus on both technical (forest and resource management) aspects and social aspects, such as fair distribution of benefits, participation of community members in decision-making, transparency, checks and balances within community and between community and other partners

- Develop effective conflict-management mechanisms

- Secure tenure e.g. through boundary demarcation and land title or management rights

Decentralisation has opened the door for smallscale forest management in Indonesia. The question is, what role can communities have in small-scale forest management? The list of constraints to the development of community forestry is substantial, but given the potential advantages it is well worth the effort. Pilot projects supported by networks for shared learning will be important to gain insights and provide examples to other communities. The district governments should support local initiatives to stimulate policy debate at district and central government level to develop further opportunities for communities to practise and benefit from forestry.

While going through the above mentioned steps, we learned that it is important to consider the time allocated to each step. A quick process may utilise the momentum of a community's initial interest. However, the risk exists that not all options or information are considered in the process. By allocating more time, information will be more complete and allow for more careful consideration of options. By using an iterative process, shortcomings in the first phase can be addressed in the next phase. However, community members may also lose interest if the process is too slow, as this escalates the transaction costs which are not shared equally amongst all stakeholders (Adhijari and Lovett, 2006). We found that iterative discussion over a four-year period was too long. It would have been better for us to have had an initial intensive involvement in the first year to achieve immediate tangible products and then use the following years to refine them. Generating tangible benefits is important in sustaining participation (Salam and Noguchi, 2006). As the facilitation of village land-use planning is time consuming and labour intensive, one possibility to address these problems is to develop local capacity, starting from the appropriate agencies in the district government and gradually including the sub-district administration and the communities. Over time, the development of local capacity will make the process less time- and labourdemanding and will also make the process more sustainable in the long term.

Input from government agencies about existing or planned development programmes are needed in the process. The timing of this input is important but also problematic: if government input is provided too early, it can limit the exploration of interests and priorities of the community. If the input is too late, the results of community discussions might be redundant since they do not match government planning or might be difficult to accommodate in the government planning process. We suggest that communities produce a first draft relatively quickly and request feedback immediately.

Our experience has been that local government interest in village land-use plans is minimal and that it is difficult to show the relevance of these plans when the district land-use plan itself is of limited real utility in how people make decisions based on economic incentives. Based on arguments such as the size of the district and limited human and financial resources, the district government tends to focus on large-scale planning and development. To illustrate this problem, we quote a consultant involved in the development of the Malinau district land-use plan: 'Village land use planning is too micro, we have to focus on the big picture.' In his opinion, including village land-use planning in district land-use planning was impractical. Yet the 'big picture' requires an understanding of villager's 
needs and visions. A more bottom-up planning process is required that makes use of these smaller units.

To accommodate a more bottom-up landuse planning process, the district government faces several constraints: lack of experience with bottom-up processes and genuine public consultation; few staff members with appropriate training in the technical aspects of land-use planning; or the skills to facilitate communities in expressing their needs and interests to feed into the land-use planning process. The situation is aggravated by a lack of reliable maps and good quality data.

\section{CONCLUSION AND RECOMMENDATIONS}

Including village land-use planning in district land-use planning faces serious problems: lack of data, maps, experience and time pressure for district government, and different scales of interest at the village and district level. However, the potential benefits are significant: detailed additional information on land use and resource potential is made available, land-use plan and development activities are better known, especially if linked to local priorities and are hence more acceptable to communities. This process would also support village boundary definition and inter-village coordination and cooperation, which are greatly needed for coordinated forest management in Malinau.

\section{How can it be done?}

Villagers can provide input to district land-use planning through village area maps. The maps should show the types of existing and desired forest management, and translate their local land-use categories into terms that can match designated land functions at the district level, such as protected forests and production forests (for commercial timber harvesting). Districts should consider creating a land-use category of forests for shifting cultivation.

Villagers should discuss their initial plans with government officials, realising that they may need to be strategic in the types of information they share with different individuals. Likewise, government officials or the consultants producing the land-use plan should solicit village input and plans early in the district process. District officials should present general principles, targets and land-use categories in open village meetings. Both sides should be given ample opportunities to reflect and revise their plans.

It will be necessary in the beginning to facilitate the village planning processes and the links between districts and communities. The district government should be able to locate consultants to assist them; the consultants would at the same time be building local capacity.

It is essential that the districts provide communities with copies of the district map to show how their input has been taken account of and to guide the community in their own local land-use planning.

Only with this sort of coordination between communities and the district will there be any hope of creating forest management systems that meet local people's needs in a coordinated way.

\section{REFERENCES}

Adhijari, B. and Lovett, J.C. 2006. 'Transaction costs and community-based natural resource management in Nepal'. Journal of Environmental Management, 78: pp. 5-15.

Agrawal, A. 2001. 'Common property institutions and sustainable governance of resources'. World Development, 29: pp. 1649-72.

Bratawinata, A., 1986. Bestandsgliederung eines Bergregenwaldes in Ostkalimantan / Indonesian nach floristischen und strukturellen Merkmalen. PhD thesis. Georg August Universitat, Gottingen, Germany.

Brown, T.H. 2004. Analysis of Population and Poverty in Indonesia's Forests. NRM Program, Jakarta Indonesia. December 2004.

Dolisca, F., Carter, D.R., McDaniel, J.M., Shannon, D.A. and Jolly, C.M.. 2006. 'Factors influencing farmers' participation in forestry management programmes: a case study from Haiti'. Forest Ecology and Management, 236: pp. 324-31. 
Fabricius, C., Koch, E., Magome, H. and Turner, S. (eds). 2004. Rights, resources and rural development: community-based natural resource management in southern Africa. Earthscan, London.

Kumar, S. 2002. 'Does participation in Common Pool resource management help the poor? A social cost-benefit analysis of Joint Forest Management in Jharkhand, India'. World Development, 30: pp. 763-82.

Lise, W. 2000. 'Factors influencing people's participation in forest management in India'. Ecological Economics, 34: pp. 379-92.

Oström, E. 1990. Governing the commons: the evolution of institutions from collective action. Cambridge University Press, Cambridge.

Perhutanan Sosial. 2003. Warta Kebijakan No. 9. CIFOR. Bogor, Indonesia, CIFOR.

Salam, M.A. and Noguchi, T. 2006. 'Evaluating capacity development for participatory forest management in Bangladesh's Sal forests based on "4Rs" stakeholder analysis'. Forest Policy and Economics, 8: pp. 785-96.

Sheil, D., Puri, R.K., Basuki, I., van Heist, M., Wan, M., Liswanti, N., Rukmiyati, Rachmatika, I. and Samsoedin, I. 2006. 'Recognizing local people's priorities for tropical forest biodiversity'. Ambio 35(1): pp. 17-24.
Sidiyasa, K., 1987. 'Composition and structure of a "tengkawang" (Shorea stenoptera Burck) forest at Sekadau, West Kalimantan'. For. Res. Bull. 490: pp. 13-23.

Sidiyasa, K., Ahmad, Z. and Iwan, R. 2006. Hutan Desa Setulang dan Sengayan Malinau, Kalimantan Timur: Potensi dan identifikasi langkah-langkah perlindungan dalam rangka pengelolaannya secara lestari. CIFOR, Bogor, Indonesia.

Turner, S. 2004. 'Community-based natural resource management and rural livelihoods'. In: Fabricius, C., Koch, E., Magome, H. and Turner, S. (eds). 2004. Rights, resources and rural development: community-based natural resource management in southern Africa. Earthscan, London.

Valkenburg, J.L.C.H. van. 1997. Non-timber forest product of East Kalimantan: potential for sustainable forest use. Tropenbos Series 16. The Tropenbos Foundation, Wageningen, the Netherlands. 



\section{CHAPTER 9 THE USE OF WOOD WASTE FOR COMMUNITY-LEVEL INCOME-GENERATION INITIATIVES}

Haris Iskandar, Kresno Dwi Santosa, Markku Kanninen and Petrus Gunarso 


\section{INTRODUCTION}

It has long been appreciated that logging activities in natural forests throughout the world can have deleterious impacts on the local ecosystem processes and biodiversity (Johns, 1988; Whitmore and Sayer, 1992; Anderson et al., 2002). However, the positive economic gains from logging operations have usually been sufficient to brush aside criticism of these negative aspects. This is now being questioned at both the national and local levels. At the national level, approaches such as full-cost accounting, in which the full ecological and societal costs of any land-use system can be factored into the economic models of profitability, have raised serious questions concerning the economic validity of some practices. At the local level, more refined and micro-level analysis of logging operations have indicated that there is economic sense in applying increased direct management and more-conservation friendly approaches, such as reduced impact logging (e.g. Barreto et al., 1998; Holmes et al., 2002).

Much of the research into improving logging practices to maximise profitability, whilst simultaneously lowering damage to the remaining forest, has focused on tree selection, felling techniques and optimal design of skid paths to extract the timber (e.g. Barreto et al., 1998; Trockenbrodt et al., 2002; see also Priyadi, this volume). In comparison, the post-harvest situation has received relatively little attention. Yet a casual visit to any post-logging site reveals considerable volumes of timber left in situ. This timber is discarded for a number of reasons. It includes trimmings of small-diameter branches, non-target species smashed when the target tree is felled, hollow logs of target species, and trees smashed or felled to create skid paths and log yards (Uhl and Veira, 1989; Sist and Bertault, 1998). There is a prevailing view that this wood is of inadequate quality to add to the profitability of the timber companies, and management of the waste will only increase production costs (Tetter, 1994; Havelund and Ahmad, 1999).

There are a number of studies, from plantations and natural systems, that have quantified the volume of wood left behind after logging and the potential benefits of leaving it in situ (e.g. Jaeger, 1989; Gunnarsson et al., 2004;
Chen and Zu, 2005), including work in East Kalimantan (Darsani, 1986; Muladi, 1998; Sist and Bertault, 1998; Gumartini, 2001). Yet, with decentralisation policies in place and the new district authority seeking to stimulate local economic development, interest is high in possible income-generating opportunities from waste wood. Consequently it is now being considered from an economic perspective rather than a forest management perspective. This is particularly applicable under the new smallscale concession system in the region (known as IUPHHK), in which each company receives rights of 20,000 to 35,000 ha for 20 years, and the concessionaire must follow the national guidelines on selective cutting and replanting (Departemen Kehutanan, 1993). Moreover, the waste left behind, of potentially useful species, contributes to conflict between logging companies and local communities (Yasmi, 2003).

This concern, and potential opportunity, applies not only to the logging activities of small-scale timber concessionaires, but also to the slashand-burn activities of local communities in clearing secondary forest or swidden fallows. Traditionally, local communities open up swiddens (locally called ladangs), usually less than 1 ha per household, every few years for rice cultivation, along with other agricultural species such as taro. The wood that is felled or cleared to create the swidden is either burned, with the ash acting as a fertiliser (Sheil et al., 2004), although most of it leaches after the first few rains, or alternatively the wood is left on site where it serves a number of functions; it may (i) suppress the regrowth of shrubs, (ii) provide pathways to walk along, and (iii) act as a physical barrier to soil movement and so reduce erosion. Since approximately 5,000 ha of swiddens are cleared per year in the region (Dinas Pertanian Malinau, 2004) by this method, there is once again significant potential for large amounts of waste wood to be generated. Indeed, from the assessment in Malinau, it was found that the annual deforestation rate from opening ladang by local communities for shifting cultivation was much higher than those from logging activities by concessionaires. However, the total amount of wood waste in ladang would depend upon where the new ladang were cleared, namely in secondary forest or old ladang. Work in Peru (Coomes and Burt, 2001) has shown that 
charcoal production, often cast as a rapacious, wasteful use of the forest, can provide significant cash income for forest peoples and high returns per hectare, particularly when integrated into swidden-fallow agroforestry systems, without causing notable forest destruction.

Within the context of the above, a study was initiated to (i) ascertain the amount of waste wood generated by small-scale concessions and shifting cultivation activities (swiddens), and (ii) consider possible uses for the waste wood.

\section{APPROACH}

\section{Study site}

The study was carried out between November 2004 and February 2005 in Malinau District, East Kalimantan (Figure 1), including both smallscale concession (IUPHHK) logging areas and areas cleared for shifting cultivation by local communities. In most of the logging concessions, the forest type was predominantly lowland and sub-montane tropical forest, dominated by trees of the Dipterocarpaceae family. The altitude ranged from 100 to $200 \mathrm{~m}$ above sea level, with a flat to rolling topography with $8-15 \%$ slopes (Machfudh, 2001). Monthly rainfall ranges from $200-400 \mathrm{~mm}$, with an annual total of approximately $4,000 \mathrm{~mm}$. Soils are highly weathered Oxisols (Basuki and Sheil, 2005).

\section{Sample site and plot distribution}

There are currently five small-scale (IUPHHK) concessions in Malinau District. Four of these were selected for the study: two on the northern side of the Sesayap River and two on the southern side. These were each matched by a swidden site (therefore four swiddens) in reasonable proximity to local communities who may be able to use the waste wood. To estimate the potential biomass of trees prior to swidden clearance, several sites were established in the secondary forests and old ladang located next to new swiddens.

Within the concession areas, sample plots were established along logging roads, using a line transect of $100 \mathrm{~m} \times 50 \mathrm{~m}$. The centre line along the road was applied as a reference line, with the plot then established $25 \mathrm{~m}$ on either side. Replicate plots were located every $900 \mathrm{~m}$ along logging roads recently constructed by each IUPHHK contractor (Figure 2). In log yards, two sample plots were established per concession. Plots were established within $25 \mathrm{~m}$ from the

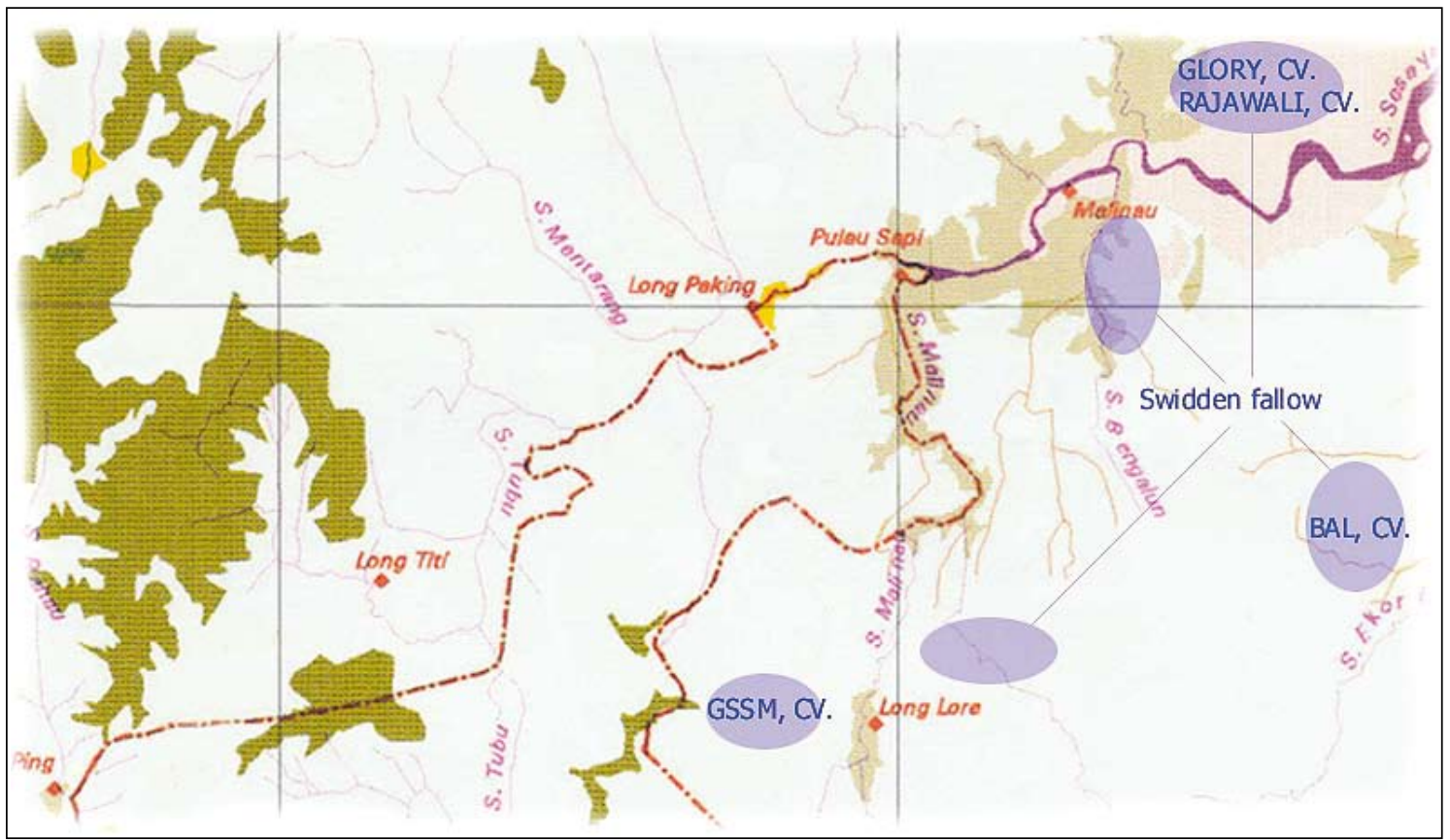

Figure 1. Map of the study site and plot distribution in Malinau, East Kalimantan 


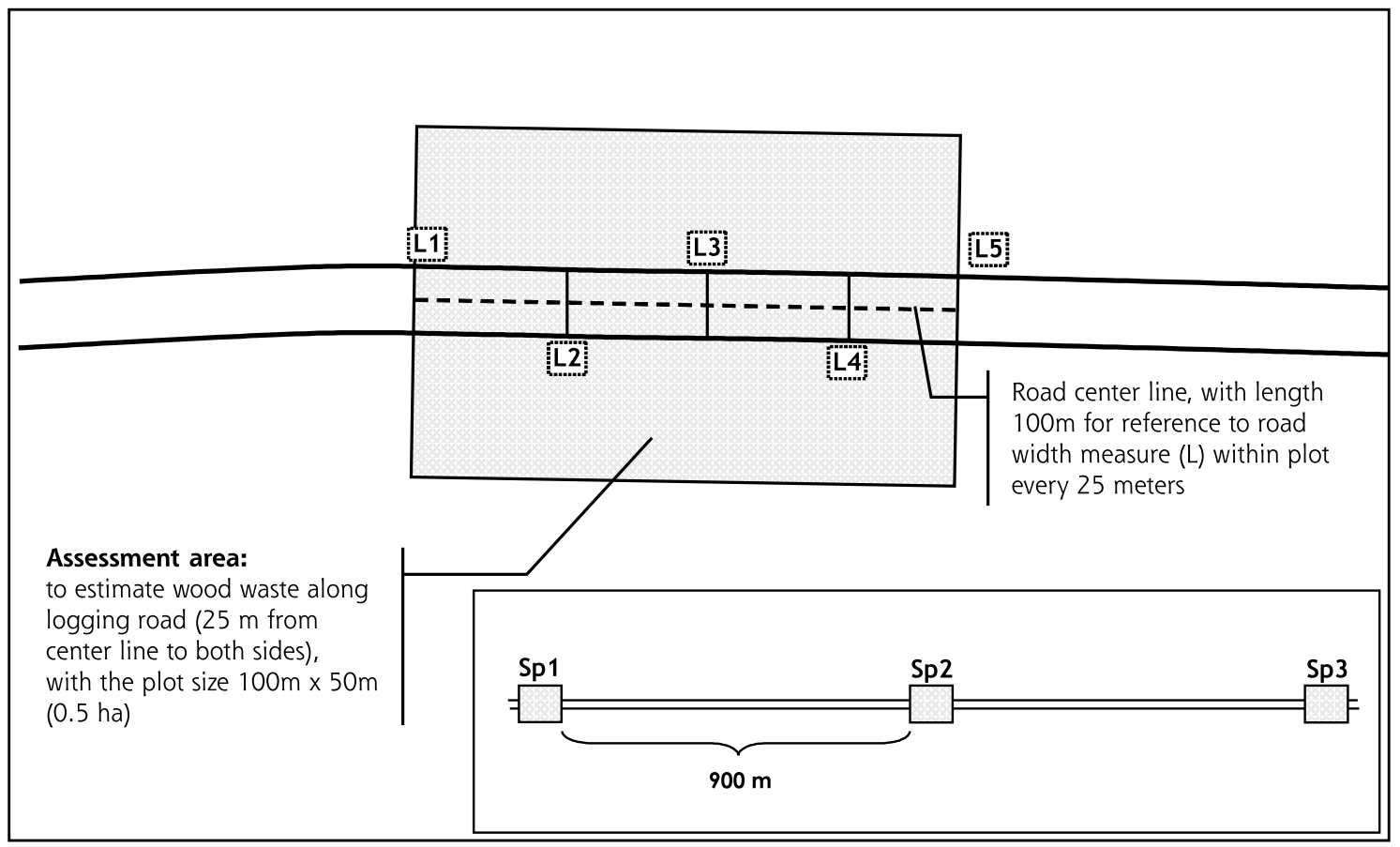

Figure 2. Plot layout to estimate wood waste along logging road

outer periphery of the log yard. The width of the opened area was estimated by measuring the distance from the centre to each edge in eight directions using a digital range-finder (Laser Technology, 1998) (Figure 3).

Recently created ladang were sampled by means of $50 \mathrm{~m} \times 50 \mathrm{~m}$ plots which were randomly situated. Due to the high density of trees, plots in old ladang or secondary forest were smaller, i.e $10 \mathrm{~m} \times 10 \mathrm{~m}$ each. Three replicates were established per site (therefore 12 plots in total). Only standing trees greater than $10 \mathrm{~cm}$ dbh were measured.

At each site the diameter of all pieces of wood waste greater than $5 \mathrm{~cm}$ was measured using a diameter tape and classified into one of six categories:

1. Left logs: mainly logs missed during skidding operations and trees that were pushed over during road construction.

2. Broken logs: damaged or split logs resulting from improper handling during felling and skidding operations.

3. Butt end: waste from excessively long buttress cut by the feller, and short pieces of logs from bucked or removed logs because of minor defects.
4. Top logs and branches: the main stem after the first major branch and the branches (often of top quality timber).

5. Stumps: high stumps due to buttresses.

6. Standing dead trees: severely damaged trees caused by the felling of target trees and during road construction.

\section{Volume equations}

For the compilation of wood-waste assessments, the Huber's geometric equation for the volume of a cylinder (Philip, 1994) was applied with a taper factor resulting from prior study in Kalimantan and Sulawesi (Tetter, 1994), as follows:

1. If top and butt diameters of logs could be measured, then the average of the two measurements was used:

Vol. $=\left(\mathrm{D}_{\text {average }} / 100\right)^{2}{ }_{\times}(0.7854) \times(\mathrm{L})$

2. If only the butt diameter could be measured, a taper factor of 0.7 was assumed: Vol. $=(0.7)\left(\mathrm{D}_{\text {butt }} / 100\right)^{2}{ }_{\times}(0.7854) \times(\mathrm{L})$

3. If only the top diameter could be measured, then a taper factor $1 / 0.7$ was used: Vol. $=(1 / 0.7)\left(\mathrm{D}_{\text {top }} / 100\right)^{2}{ }_{x}(0.7854) \times(\mathrm{L})$

4. Diameter nearest to the soil surface was measured for standing dead trees: Vol. $=(0.7)\left(\mathrm{D}_{\text {but }} / 100\right)^{2}{ }_{x}(0.7854)_{\mathrm{x}}(\mathrm{Ht})$ Where; Vol. $=$ volume in cubic metres $\left(\mathrm{m}^{3}\right)$ 


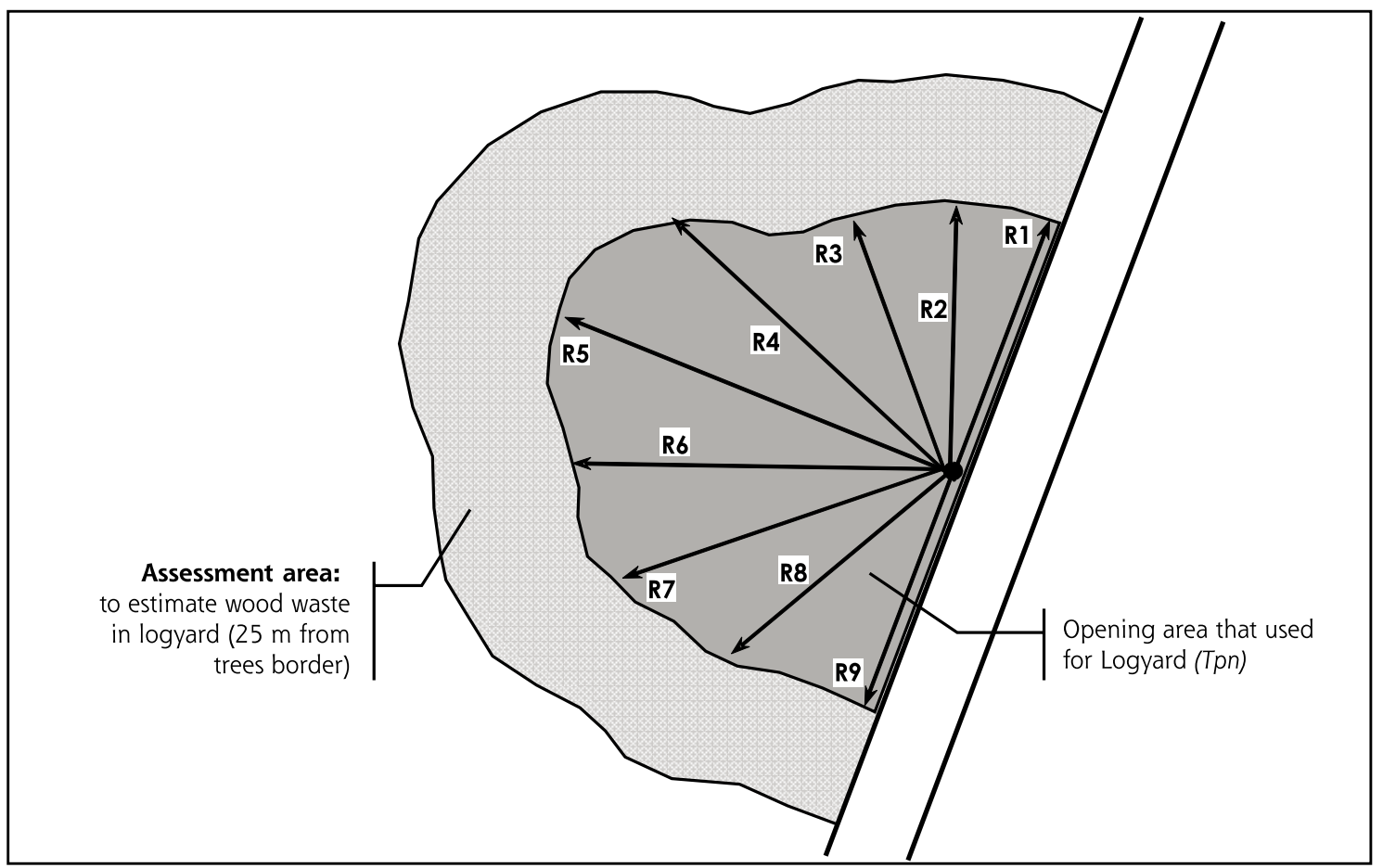

Figure 3. Plot layout to estimate wood waste in logyard (TPn)

$\mathrm{D}_{\text {average }}=$ average or mid diameter in centimetres $(\mathrm{cm})$

$\mathrm{D}_{\text {butt }}=$ butt diameter in centimetres $(\mathrm{cm})$

$\mathrm{D}_{\text {top }}=$ top diameter in centimetres $(\mathrm{cm})$

0.7 = taper factor

$0.7854=\pi / 4$

$\mathrm{L}=$ length in metres $(\mathrm{m})$

$\mathrm{Ht}=$ tree height in metres $(\mathrm{m})$

\section{Data compilation}

Wood-waste volume was estimated for each waste category and plot location, based on the total areas in both activities. In the case of log yard and ladang plots, the results were recorded in cubic metres per hectare $\left(\mathrm{m}^{3} / \mathrm{ha}^{-1}\right)$. For plots along logging roads, the data were recorded in cubic metres per kilometre $\left(\mathrm{m}^{3} / \mathrm{km}^{-1}\right)$. Thereafter, the total volume of waste was estimated based on annual total length of logging road and area opened for log yards by IUPHHK contractors. The total amount of wood waste from shifting cultivation was estimated based on the total average of land demand for ladang in Malinau District per year obtained from agricultural services. Data were analysed with Microsoft ${ }^{\circledR}$ Excel and SPSS.

\section{Charcoal manufacture and wood vinegar generation}

The earth-pit kiln system is the most well-known technique among the local communities for producing charcoal. However, a number of other techniques exist, many with better aeration control during the process resulting in higher yields of charcoal and by-products such as wood vinegar. In particular, there are two techniques that are relatively economical with respect to capital costs and could be well adapted for the local communities. These are the drum-kiln and flat-kiln systems. During the activities in Malinau, we promoted the earth-pit kiln due to its wide acceptance and low costs, along with the drum-kiln system for its practicality, ease of manufacture and mobility, allowing it to be moved from place to place where waste wood is plentiful.

To construct the earth-pit kiln, a wooden stake is driven in the ground at the centre of the site, and split wood is then piled against the stake, building up a squat cone of wood that is crowned with smaller logs. Wooden stakes are driven into the ground at the base of the wood cone and a low 
wall of slats or palm fronds is built around the base to support subsequent layers and to provide ventilation. Fresh palm fronds are then layered over the wood-pile, followed by a large volume of soil that is packed to form the outer crust that seals the kiln. A medium-sized kiln contains approximately $1.5 \mathrm{~m}^{3}$ of wood. Construction of a drum kiln is much simpler and relatively similar, and contains approximately $0.3 \mathrm{~m}^{3}$ of wood (but more can be added if required). During the charcoal making, the wood vinegar was collected from 'white clear' smoke emitted out of the drum via a pipe and then through a chiller tunnel system (usually from fresh bamboo trunks) to obtain the sap.

Charcoal production consumes only a small percentage of wood generated by field clearance for swidden-fallow agriculture. Typically, households clear about $0.5 \pm 1.0$ ha of secondary fallow forest to begin a new field but effectively collect wood for charcoal from only a fraction of this area, much of the remaining fallen timber in the newly opened field (which could potentially serve as charcoal wood) is consumed by fire when the field is burned prior to planting.

\section{FINDINGS}

The majority of forest operations by the IUPHHK contractors are still conducted without sitespecific planning of the logging activities, contrary to the permit conditions. This resulted in extensive impact on the residual stand and probably on environmental attributes, such as soil and water. The production camps and log yards also failed to comply with the Indonesian silvicultural system (Figure 4). There was frequent return to the logged areas to extract left logs and harvest other commercial timber. These impacts could be reduced through appropriate and sitespecific logging planning, periodic monitoring of logging activities and general compliance with the annual operation plan required under the Indonesian Selective Cutting and Planting system.

\section{Logging roads and log yards}

During our study, only two of the contractors actively constructed new logging roads and log yards in the 2004 annual working plan. On average, within a 1,000 ha forest block, between

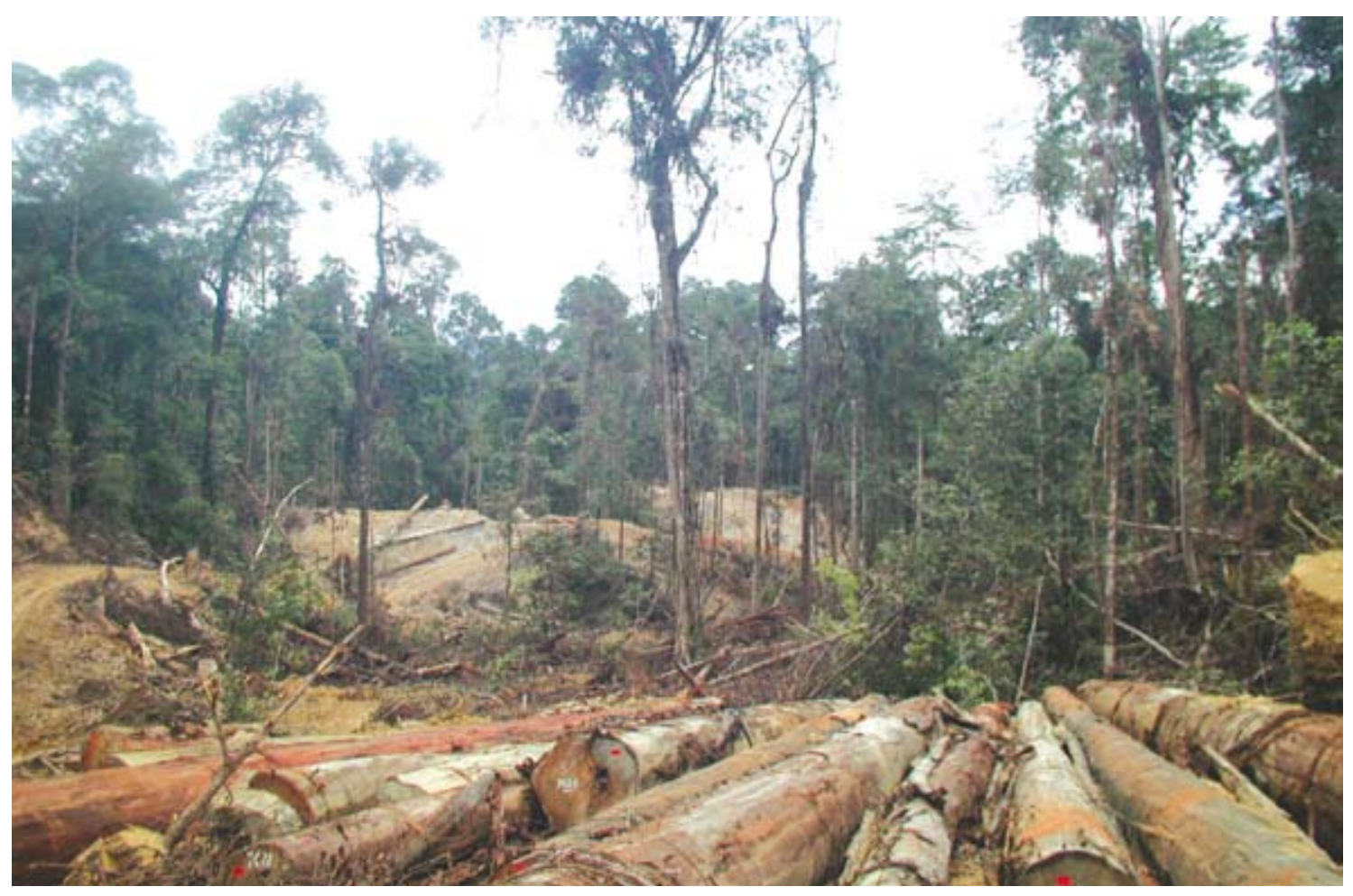

Figure 4. Condition of cutting block and Logyard during IUPHHK logging activities (Photo by Haris Iskandar) 
4 to $6 \mathrm{~km}$ of logging roads were constructed, along with three to five log yards. The average size of the opened area for each log yard was $0.8 \mathrm{ha}$, which could be increased depending on the number of extracted trees, skid-trail network and local topography within the cutting block.

The amount of potential wood waste along roads was $781 \mathrm{~m}^{3} / \mathrm{km}^{-1}$, or $99 \mathrm{~m}^{3} / \mathrm{ha}^{-1}$. Most of this $\left(51 \% ; 340 \mathrm{~m}^{3} / \mathrm{km}^{-1}\right)$, was comprised of left logs (category 1). In addition, standing dead trees and butt-waste categories comprised
$18 \%$ and $12 \%$ to total waste volume $\left(141 \mathrm{~m}^{3} /\right.$ $\mathrm{km}^{-1}$ and $93 \mathrm{~m}^{3} / \mathrm{km}^{-1}$ ), respectively. Waste from road construction in this study was higher than figures reported in West Kalimantan (Klassen, 1994), which estimated only from left logs and butt-waste categories $\left(3.4 \mathrm{~m}^{3} / \mathrm{ha}^{-1}\right.$ or $7 \%$ of the volume of harvested logs).

Approximately $30 \%$ of the waste logs along the roads was in the $10-30 \mathrm{~cm}$ diameter class (Figure 5), followed by diameter classes $\geq 50$ (23\%) and 20-30 cm (21\%) (Table 1). However,

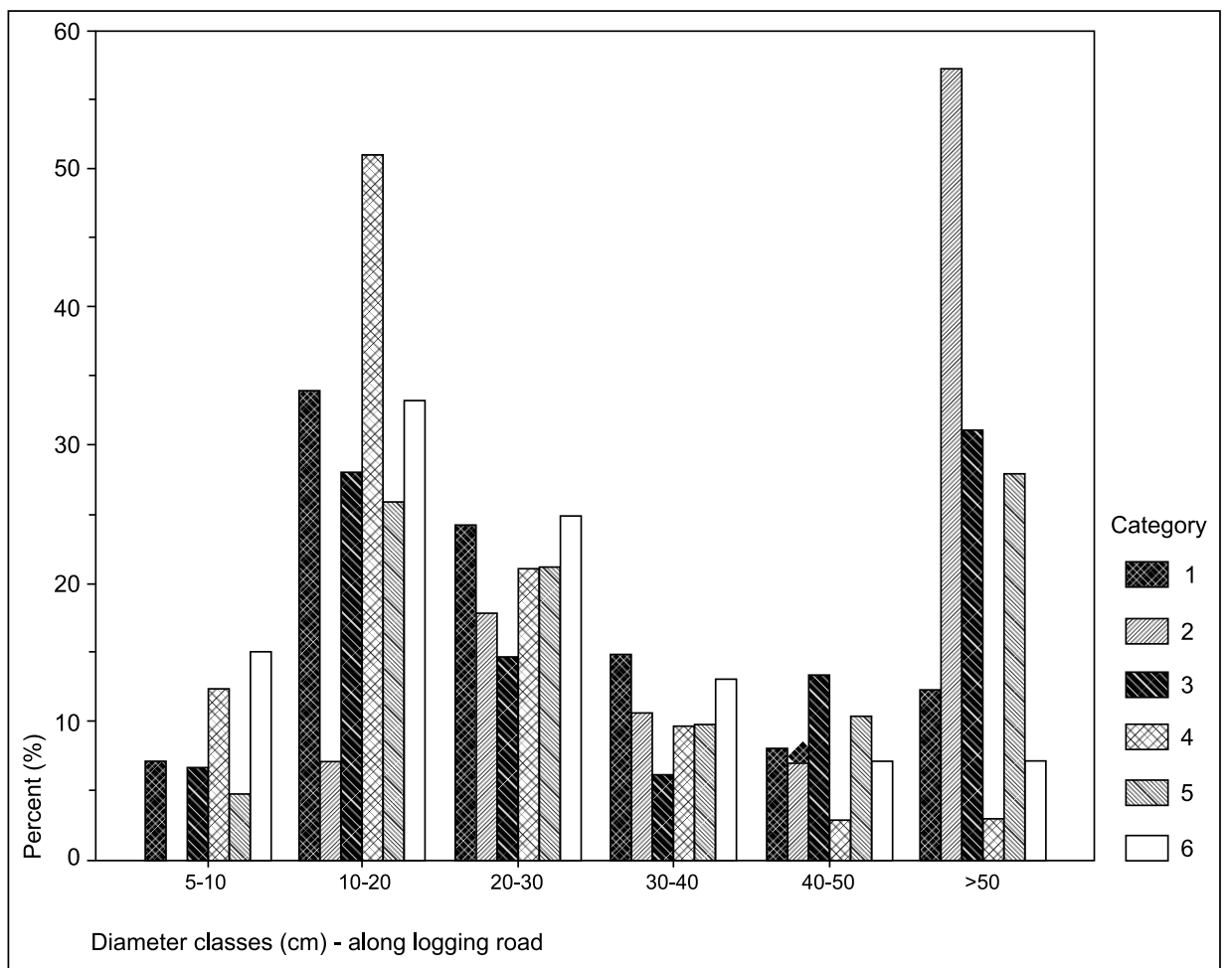

Figure 5. Diameter distribution of wood waste along logging road

Table 1. Wood waste volume $\left(\mathrm{m}^{3} \mathrm{ha}^{-1}\right)$ and category distribution - from Logging roads construction by IUPHHK

\begin{tabular}{ccccccc}
\hline \multirow{2}{*}{ Category } & \multicolumn{2}{c}{ diameter $<\mathbf{1 0} \mathbf{c m}$} & \multicolumn{2}{c}{ diameter $\geq \mathbf{1 0} \mathbf{c m}$} & \multicolumn{2}{c}{ Total } \\
\cline { 2 - 7 } & volume & $\%$ & volume & $\%$ & volume & $\%$ \\
\hline 1 & 4.43 & 45.76 & 395.21 & 51.26 & 399.64 & 51.19 \\
\hline 2 & 0.02 & 0.25 & 49.79 & 6.46 & 49.81 & 6.38 \\
\hline 3 & 0.17 & 1.74 & 92.42 & 11.99 & 92.59 & 11.86 \\
\hline 4 & 3.32 & 34.31 & 46.74 & 6.06 & 50.07 & 6.41 \\
\hline 5 & 0.86 & 8.89 & 46.77 & 6.07 & 47.63 & 6.10 \\
\hline 6 & 0.88 & 9.05 & 140.02 & 18.16 & 140.89 & 18.05 \\
\hline & 9.68 & $(1.2 \%)$ & 770.95 & $(98.8 \%)$ & 780.63 & $(100 \%)$ \\
\hline
\end{tabular}


waste of the diameter class $\geq 50 \mathrm{~cm}$ contributed the largest quantity to the total volume $(61 \%$ or $478.5 \mathrm{~m}^{3} / \mathrm{km}^{-1}$ ) mainly as left logs and buttwaste categories. Left logs contributed the most volume to every diameter class.

The total amount of wood waste from log-yard construction and re-bucking activities was 207 $\mathrm{m}^{3} / \mathrm{ha}^{1}$. Of this, the left-logs category contributed the largest portion ( $49 \%$ or $\left.101 \mathrm{~m}^{3} / \mathrm{ha}^{-1}\right)$ across all diameter classes. In addition, waste in standing dead trees and butt categories represented 21\% $\left(43 \mathrm{~m}^{3} / \mathrm{ha}^{-1}\right)$ and $12 \%\left(26 \mathrm{~m}^{3} / \mathrm{ha}^{-1}\right)$, respectively. Waste in the stumps category contributed the least $\left(9.4 \mathrm{~m}^{3} / \mathrm{ha}^{-1}\right.$ or $\left.4.5 \%\right)$.

In terms of diameter classes, wood waste in the diameter class $10-30 \mathrm{~cm}$ was the most common (53\%), but contributed only approximately onefifth $\left(19 \% ; 39 \mathrm{~m}^{3} / \mathrm{ha}^{-1}\right)$ of the waste volume. In comparison, wood waste of a diameter $\geq 50 \mathrm{~cm}$ represented a similar frequency, but constituted $57 \%\left(118 \mathrm{~m}^{3} / \mathrm{ha}^{-1}\right)$ of the total volume (Figure 6$)$, made up of left logs $(28 \%)$, broken logs $(12 \%)$,

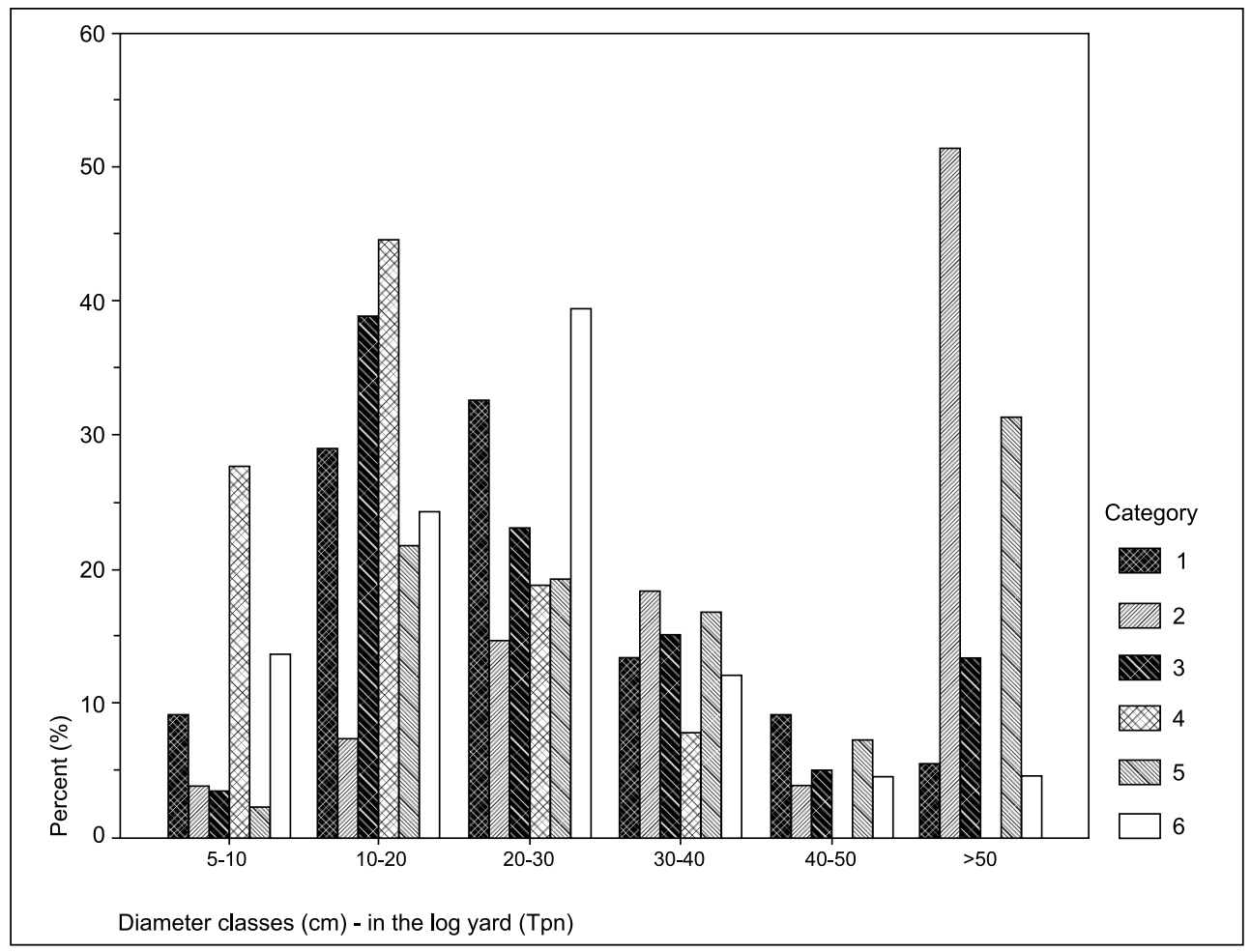

Figure 6. Diameter distribution of wood waste in log yard (TPn)

Table 2. Wood waste volume $\left(\mathrm{m}^{3} \mathrm{ha}^{-1}\right)$ and category distribution from Logyard (TPn) construction by IUPHHK

\begin{tabular}{cccccrr}
\hline \multirow{2}{*}{ Category } & \multicolumn{2}{c}{ diameter $<\mathbf{1 0} \mathbf{c m}$} & \multicolumn{2}{c}{ diameter $\geq \mathbf{1 0} \mathbf{c m}$} & \multicolumn{2}{c}{ Total } \\
\cline { 2 - 7 } & volume & \multicolumn{1}{c}{$\%$} & volume & \multicolumn{1}{c}{$\%$} & volume & \multicolumn{1}{c}{$\%$} \\
\hline 1 & 1.63 & 74.68 & 99.47 & 48.46 & 101.10 & 48.73 \\
\hline 2 & 0.02 & 0.70 & 19.06 & 9.29 & 19.07 & 9.20 \\
\hline 3 & 0.03 & 1.38 & 25.67 & 12.50 & 25.70 & 12.39 \\
\hline 4 & 0.17 & 7.62 & 9.36 & 4.56 & 9.53 & 4.59 \\
\hline 5 & 0.02 & 0.75 & 9.34 & 4.55 & 9.36 & 4.51 \\
\hline 6 & 0.32 & 14.87 & 42.37 & 20.64 & 42.69 & 20.58 \\
\hline & 2.18 & $(1.1 \%)$ & 205.27 & $(98.9 \%)$ & 207.44 & $(100 \%)$ \\
\hline
\end{tabular}


and standing dead trees (11\%). Waste of less than $10 \mathrm{~cm}$ diameter only $1 \%$ of the total volume $(2.2$ $\mathrm{m}^{3} / \mathrm{ha}^{1}$ ) and found in the left logs and standing dead trees categories (Table 2).

Overall the wood-waste categories from logging roads were relatively similar to those from logyard construction. In both situations the waste categories of left logs and standing dead trees contributed the largest portion to the total volume. Both of these categories potentially represent needless waste due to a lack of proper planning for logging-road construction (Sist and Bertault, 1998). The potential volume of wood waste from other logging studies in Kalimantan and Sumatera, Indonesia (Enters, 2001; BAPPENAS, 1998; Sist and Bertault, 1998; Kurniawan, 1996; Darsani, 1986), ranged between $30 \%$ and $40 \%$ of harvested timber, approximately 50 to $85 \mathrm{~m}^{3 /}$ ha $^{-1}$. In most of these studies, however, standing dead and severely damaged trees by logging activities were not included as part of the wastewood inventory. At one extreme, the work of Jaeger (1999) in Malaysia has shown that the amount of indirect waste categories could be as much as double the volume of the logs actually extracted.

\section{Ladang, secondary forests and old ladang}

Wood waste in ladang consisted largely of left logs and stumps, somewhat different from the logging roads and log yards. The traditional process of ladang opening, inherited from the ancestors over centuries, pays no special attention to its waste. The fallen trees are often left to suppress the growth of shrubs or they are burned to provide ash for the soil. However, in most of the ladang sites sampled, we found that debris of various dimensions was not completely burned and still had potential for other purposes. Opening ladang for shifting cultivation resulted in an average of $63 \mathrm{~m}^{3} / \mathrm{ha}^{-}$ ${ }^{1}$ of wood waste, with the highest proportion as left logs in all diameter classes $\left(46 \mathrm{~m}^{3} / \mathrm{ha}^{-1}\right.$; $73 \%$ of total volume, Table 3$)$. Stumps made up the remainder $(27 \%)$ of the total volume $(17$ $\left.\mathrm{m}^{3} / \mathrm{ha}^{-1}\right)$. Most $(80 \%)$ of the waste wood was in the two smallest diameter classes, with $39 \%$ and $41 \%$, respectively (Figure 7 ).

In comparison, the potential amounts of wood waste from opening up old ladang in Sesua and Putat-Kaliamok ranged between 32 and $37 \mathrm{~m}^{3}$ / $\mathrm{ha}^{-1}$. Results from the secondary forest plots were far more variable. Values for sites in Sembuak and Kaliamok were approximately 110 and $126 \mathrm{~m}^{3}$ / ha $^{-1}$, whereas those at the Adiu and Gong Solok sites had approximately half of this, i.e. 54 to 57 $\mathrm{m}^{3} / \mathrm{ha}^{-1}$ respectively. Whether these differences relate to inherent site and forest differences or logging history is unclear. However, the sites near Adiu, Sesua and Gong Solok villages were heavily logged by the concessionaires relative to the Putat-Kaliamok and Sembuak sites.

The potential timber volume and number of trees of $>10 \mathrm{~cm}$ dbh from secondary forests plots in Putat-Kaliamok and Sesua villages were relatively high. Key species such as Meranti (Shorea sp.), Artocarpus sp. (Terap, Cempedak, Sukun) and Darah-darah (Myristicaceae) comprised a significant proportion of the timber volume, representing $496 \mathrm{~m}^{3} / \mathrm{ha}^{-1}$ (59\%), $115 \mathrm{~m}^{3}$ / ha $^{-1}(14 \%)$, and $86 \mathrm{~m}^{3} / \mathrm{ha}^{-1}(10 \%)$, respectively. Each had over 100 stems $^{-1}$ (Figure 8). On average there were approximately $846 \mathrm{~m}^{3} / \mathrm{ha}^{-1}$ (or 622 trees per $\mathrm{ha}^{-1}$ ) in the secondary forest, which could potentially be used if it is not burned. The burned sites had less than $10 \%$ of this volume; only $63 \mathrm{~m}^{3} / \mathrm{ha}^{-1}$.

Table 3. Wood waste volume $\left(\mathrm{m}^{3} \mathrm{ha} \mathrm{a}^{-1}\right)$ and category distribution from shifting cultivation activities by local communities in Malinau

\begin{tabular}{ccccccc}
\hline \multirow{2}{*}{ Category } & \multicolumn{2}{c}{ diameter $<\mathbf{1 0} \mathrm{cm}$} & \multicolumn{2}{c}{ diameter $\geq \mathbf{1 0} \mathrm{cm}$} & \multicolumn{2}{c}{ Total } \\
\cline { 2 - 7 } & volume & $\%$ & volume & $\%$ & volume & $\%$ \\
\hline 3 & 12.37 & 83.51 & 43.67 & 90.14 & 46.11 & 72.89 \\
\hline 5 & 2.44 & 16.49 & 4.78 & 9.86 & 17.15 & 27.11 \\
\hline & 14.81 & $(23.4 \%)$ & 48.45 & $(76.6 \%)$ & 63.26 & $(100 \%)$ \\
\hline
\end{tabular}




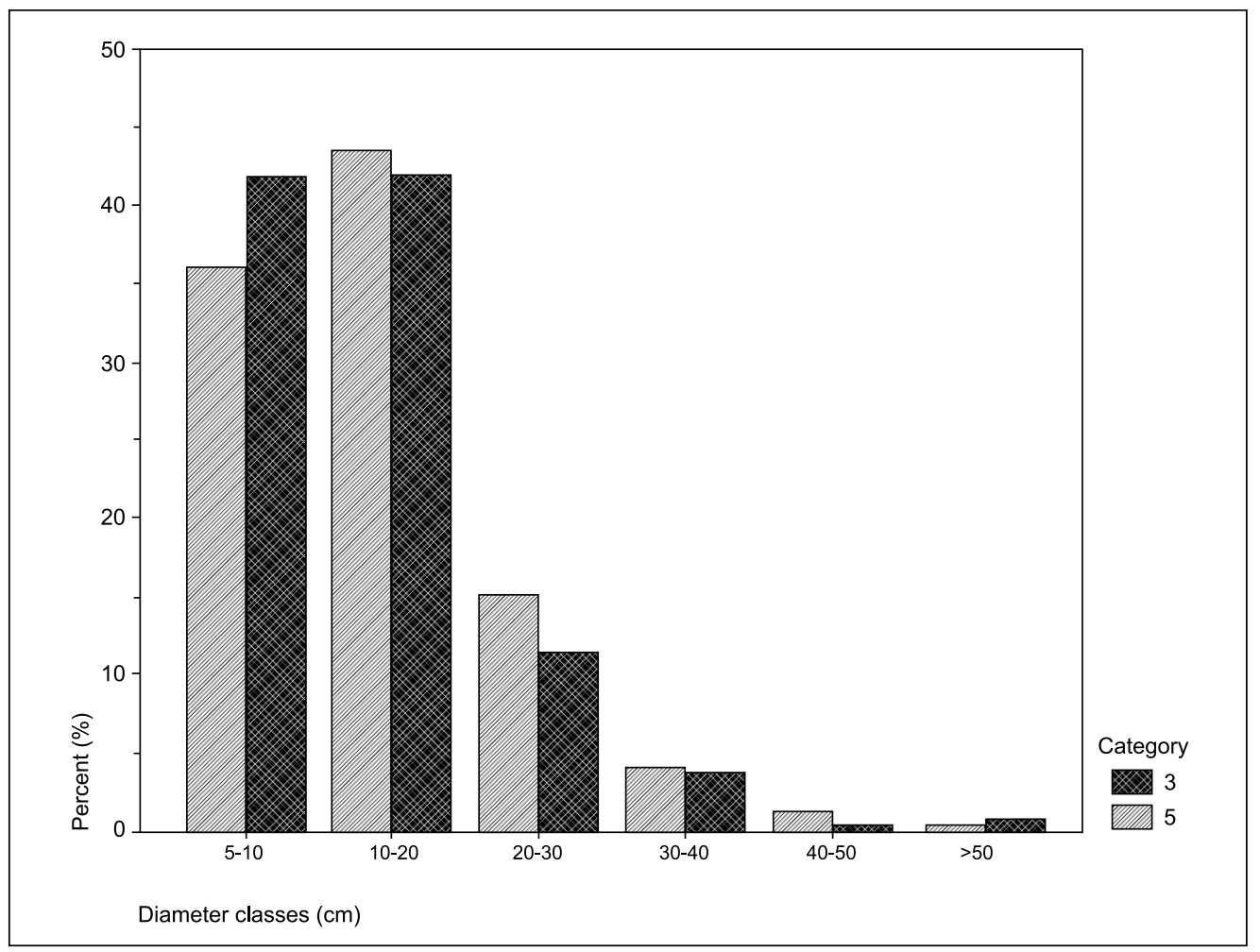

Figure 7. Diameter distribution of wood waste in shifting cultivation land (ladang)

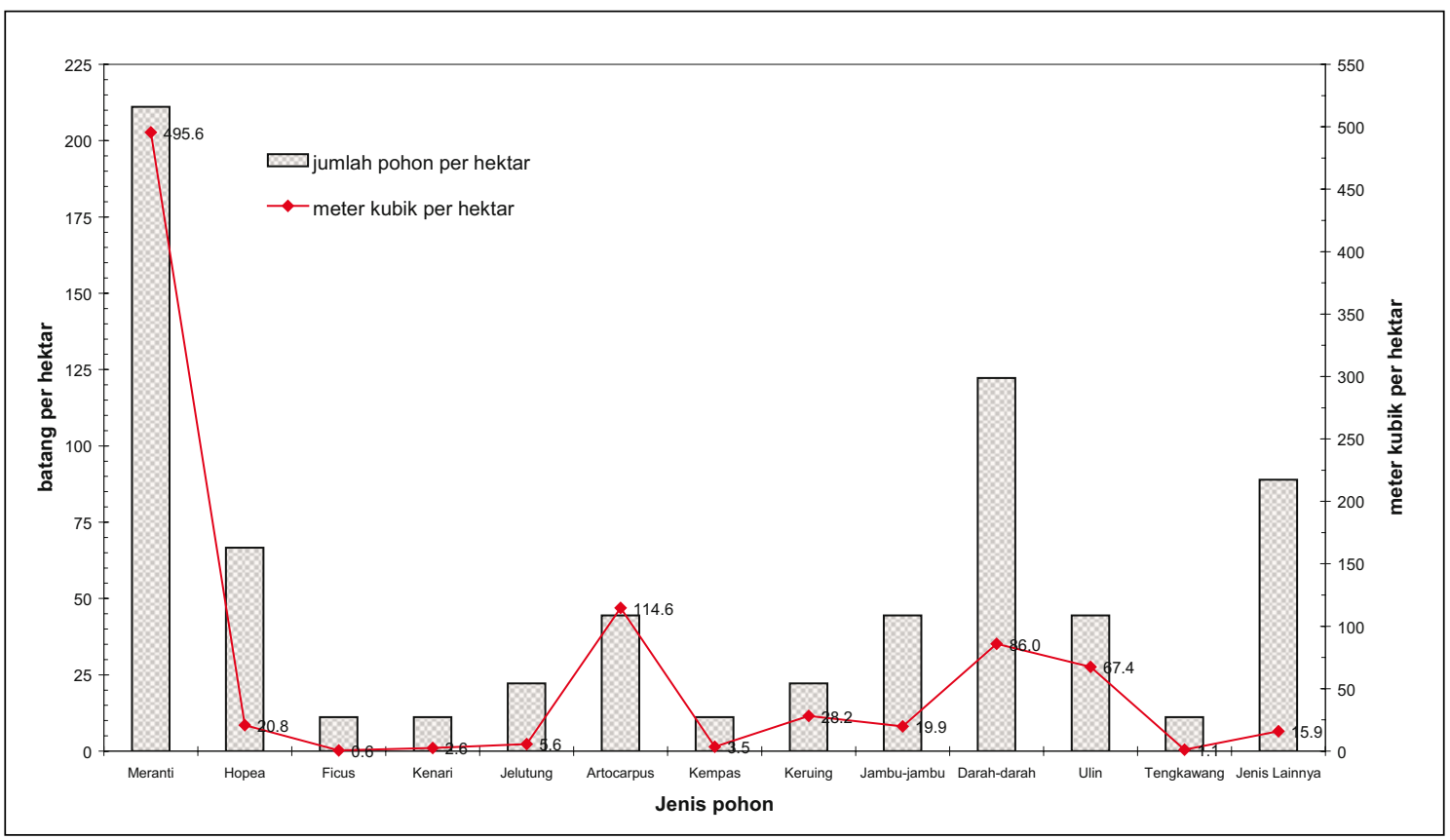

Figure 8. Potential timber in secondary forests prior to slash and burn activities 
Furthermore, in young jakau (fallow) plots, the potential wood waste was quite large, up to $355 \mathrm{~m}^{3} / \mathrm{ha}^{1}$ (or 700 trees per ha-1). However, it was also noticed that Macaranga sp. and Eugenia sp. (jambu-jambu) were the dominant trees $\left(109 \mathrm{~m}^{3} / \mathrm{ha}^{-1}\right.$ or $31 \%$ and $74 \mathrm{~m}^{3} / \mathrm{ha}^{-1}$ or $21 \%$, respectively), whereas secondary forest plots were dominated largely by meranti and Artocarpus sp. Even though Eugenia sp. was also observed in the secondary forest plots, it was a relatively small constituent (45 trees ha-1 or 20 $\left.\mathrm{m}^{3} / \mathrm{ha}^{-1}\right)$, and Macaranga sp. was absent.

\section{Use of wood waste for charcoal and wood vinegar}

Charcoal application as a soil conditioner can uphold and increase the soil Cation Exchange Capacity (CEC), soil layer effective area, soil C-organic, as well as to provide more micro and macro-pores to control soil humidity and water balance. Our results showed that charcoal produced from the different timber species (i.e. jabon (Antocephalus chinensis), keruing (Dipterocarpus sp.), meranti (Shorea sp.), and ulin (Eusideroxylon zwageri) using a drum-kiln system was relatively good. The water content of the charcoal was reasonably constant, at less than $10 \%$ (range $=1.2 \%$ to $9.5 \%$ ) with meranti showing the highest moisture level. Charcoal made from ulin and meranti had the lowest ash content $(<1 \%)$ and volatile matter (16 to $26 \%)$, in comparison to jabon, which had the highest ash content $(4 \%)$ and volatile matter $(29 \%$ to $37 \%$ ). The carbon yield and energy value of the charcoal from the drum kiln were relatively high, ranging between $60 \%$ to $83 \%$; an average of $6,450 \mathrm{cal} / \mathrm{g}$. These charcoal values can be improved with better aeration and temperature control during the production process.

Wood vinegar is a strongly acid $(\mathrm{pH} 2$ to $3)$, transparent liquid with a yellowish or brownish tint that contains acetic acid as the main component and over 200 types of other organic compounds. This wood vinegar, like charcoal, has been proven to have a number of effects that reflect the working of natural chemical components and has thus attracted increasing research interest. This liquid is a natural fertiliser, which is a perfect substitute for synthetic chemicals and can be used for vegetables, flowers and trees. The results from our wood vinegar analyses showed a number of essential substances. The following ranges were recorded for Acetic acid (3.359 to 7.112 ppm), o-Cresol (2.267 to 4.686 ppm), p-Cresol (1.742 to $4.269 \mathrm{ppm})$, acetone (2.125 to $4.206 \mathrm{ppm})$, methanol (1.712 to $3.378 \mathrm{ppm}$ ) and phenols (1.539 to $3.636 \mathrm{ppm}$ ). In general, charcoal and wood vinegar produced from Eusideroxylon zwageri, Dipterocarpus sp. and Shorea sp. wood was better than that obtained from Antocephalus chinensis.

\section{CONCLUSIONS AND RECOMMENDATIONS}

This study has shown that there is a large volume of wood waste from logging activities, with 780.6 $\mathrm{m}^{3} / \mathrm{km}^{-1}$ and $207.4 \mathrm{~m}^{3} / \mathrm{ha}^{-1}$ from new roads and log yards respectively. The total length of new logging roads and area of log yards constructed every year by each IUPHHK contractor was, on average, $5 \mathrm{~km}$ and 2.4 ha repectively. Thus, there will be approximately $19,515 \mathrm{~m}^{3}$ and 2,489 $\mathrm{m}^{3}$ of forest opened for new roads and log yards. Furthermore, activities of ladang clearance by local communities has also contributed a large amount of wood waste, as much as $63 \mathrm{~m}^{3} / \mathrm{ha}^{-1}$. In Malinau, the total area opened annually for ladang is 5,000 ha, and this will contribute to a potential total annual wood waste of up to $316,292 \mathrm{~m}^{3}$. All of this wood waste is potentially available for alternative uses by communities, such as furniture manufacture, traditional wood-carving, and wood charcoal production. Importantly, this wood is within close proximity to the communities and already in log form. Local people would be enriched by more information and options regarding the utilisation of waste, which could have local benefits for their own community. At the very least, it would reduce the deforestation from high demand for new ladang and the danger of forest fires, which is a valuable bonus in a country that has been devastated by such catastrophes in recent years.

Considering the high amount of wood waste generated by logging and ladang clearance, the project conducted a training programme (Training on wood waste utilisation for local community: alternatives for wood-carving and charcoal production; supported by ITTO under Project PD 39/00 Rev. 3 [F]) for local community 
participants. The training was held at the CIFOR Research Station at Seturan, South Malinau, East Kalimantan, from 17 to 27 April, 2005. Fourteen participants from the local communities attended the training: three participants each from subdistricts Malinau Kota, Malinau Barat, Malinau Utara and Mentarang, and two participants from Malinau Selatan sub-district. Observers were seven officials of Malinau District, one observer each from Dinas Perindagkop (Trade and Cooperatives Service), Kehutanan dan Perkebunan (Forestry and Plantation Service) and Pariwisata dan Kebudayaan (Tourism and Culture Service); and four from Dinas Pemberdayan Masyarakat Desa (Community Empowerment Service).

Training materials were prepared by instructors from CIFOR, FORDA and ISI (Indonesian Institute of the Arts) Yogyakarta. Three instructors from CIFOR presented the background of the training, including results of the study on potential wood waste in Malinau from logging, la dang clearance activities, techniques of harvesting and its potential wood waste. Three instructors from the Faculty of Fine Arts, ISI Yogyakarta, presented the prospect of the art of wood-carving developed from wood waste for handicrafts and furniture. Two instructors from Balitbang Departemen Kehutanan, Bogor, presented production techniques of wood charcoal and its by-product of wood vinegar.

In the practical session, instructors supervised participants in producing charcoal, handicrafts and furniture from wood waste. As a result of the training, participants will be better informed regarding the utilisation of waste, and will have a beneficial impact on their own communities, especially the change from the present traditional shifting cultivation of the slash-and-burn to slash-and-char system. The slash-and-char system increases the intensity and productivity of the ladang, helping to reduce the rate of deforestation. Furthermore, with a lack of wood supply and high demand for furniture and handicrafts in Bali and Java, there is an opportunity for Malinau to play a role as a wood supplier of either raw material or semifinished or finished products.

Based on the initial success of the first workshop, requests were made for additional ones. This was done through a number of community groups and NGOs in the area, including the Malinau Agriculture Services extension workers (Petugas Penyuluh Lapangan, PPL), a number of best farmer groups (Kelompok Tani Andalan), staff from Regional Technical Task Units (Unit Pelaksana Teknis Daerah, UPTD), and subdistrict (kecamatan) agriculture officers. The training was conducted on 27 September 2005 in UPTD office at Tanjung Belimbing, Malinau. There were 35 participants. The training was officially opened by Mr Subandi, the Head of Subdin Penyuluhan of the District Agriculture Services. This training was part of the ITTO Project activity in Malinau: 'Improved utilisation of timber harvested and currently wasted by identification of current studies on the waste and major constraints to its improved use'. Material related to an effective technology for charcoal and woodvinegar production and its application to crops and farming activities, as a soil conditioner and insecticide, was delivered by Kresno Dwi Santosa and Haris Iskandar from CIFOR Bogor. There were several lessons and illustrations and discussions groups. In the practical activities, participants were keen to make charcoal and vinegar using drum kilns. Other benefits and local uses of charcoal production were also stressed, including its use as a growth enhancer for planted trees, to mitigate smoke pollution by not practising slash and burn, as well to sequester carbon in the soil.

Whilst the results of this work show that a considerable amount of wood waste is generated and that local communities are eager to engage in possible ways of using this waste, further work is required to consider the longer-term implications of wood-waste removal, and the best ratios of what is removed and what is left. This is because the presence of logging residues and waste has been shown to have benefits for soil quality. For example, soil microbial biomass, nitrogen and carbon levels have been shown to be significantly higher, across a number of natural and plantation systems, when the waste is left on site (e.g. Mathers and $\mathrm{Xu}$, 2003). This is particularly pronounced in soils of low fertility, as at Malinau (Chen and Xu, 2005). Additionally, slash left in situ has been associated with higher species-richness of selected groups (e.g. Gunnarsson et al., 2004) and regrowth of target species (e.g. Nzila et al., 2002) in the postharvest period. Consequently, a balance between economic and ecological use of the wood waste 
needs to be found. Interim recommendations, requiring further evaluation, would be to utilise the good-quality logs (left logs, broken ones, top ends) of reasonable diameter and to leave behind the smaller diameter pieces and large buttresses and stumps that will be harder to move.

\section{ACKNOWLEDGEMENTS}

The authors acknowledge the contribution and cooperation of the Forestry and Plantation Service of Malinau district government to make this study possible. Special thanks are addressed to CIFOR colleagues in Seturan base camp, Malinau: Zakaria Ahmad, Laing, Irang, Jalung and Petrus for their invaluable contribution in gathering data in the field. The ITTO PD. 39/00 Rev. 3(F) Project funded this study.

\section{REFERENCES}

Anderson, L.E., Granger, C.W., Reis, E.J., Weinhold, D. and Wunder, S. 2002. The dynamics of deforestation and economic growth in the Brazilian Amazon. CUP, London. 259 pp.

BAPPENAS, 1998. Planning for fire prevention and drought management project: Logging residue and policy implications. Working Paper 4. ADB TA 2999-INO.

Barreto, P., Amaral, P., Vidal, E. and Uhl, C. 1998. 'Costs and benefits of forest management for timber production in eastern Amazonia'. Forest Ecology \& Management, 108: pp. 926.

Basuki, I. and Sheil, D. 2005. Local Perspectives of Forest Landscapes - A Preliminary Evaluation of Land and Soils and their Importance in Malinau, East Kalimantan, Indonesia. CIFOR. Bogor, Indonesia.

Chen, C.R. and Xu, Z.H. 2005. 'Soil carbon and nitrogen pools and microbial properties in a six-year old slash pine plantation of subtropical Australia: impacts of harvest residue management'. Forest Ecology \& Management, 206: pp. 237-47.

Coomes, O.T. and Burt, G.J. 2001. 'Peasant charcoal production in the Peruvian Amazon: rainforest use and economic reliance'. Forest Ecology \& Management, 140: pp. 39-50.
Darsani, A.S. 1986. Penelitian mengenai limbah eksploitasi secara mekanis di PT. Tanjung Raya Timber Company Ltd. Laporan Penelitian. Fakultas Kehutanan, Universitas Lambung Mangkurat.

Departemen Kehutanan. 1993. Pedoman dan petunjuk teknis Tebang Pilih Tanam Indonesia (TPTI) pada hutan alam daratan. Direktur Jenderal Pengusahaan Hutan. Departemen Kehutanan, Indonesia.

Dinas Pertanian Malinau. 2004. Statistik Pertanian Kabupaten Malinau. Dinas Pertanian, Pemerintah Kabupaten Malinau.

Enters, T. 2001. Trash or treasure?Logging and mill residues in Asia and the Pacific. AsiaPacific Forestry Commission. FAO Regional office for Asia and the Pacific, Bangkok, Thailand.

Gumartini, T. 2001. 'The Feasibility Study: Logging waste for local communities Bulungan Research Forest, East Kalimantan'. Study Report. Forest Products and People Program, CIFOR. Bogor, Indonesia.

Gunnarsson, B., Nittérus, K. and Wirdenäs, P. 2004. Effects of logging residue removal on ground-active beetles in temperate forests. Forest Ecology \& Management, 201: pp. 229-39.

Havelund, S. and Ahmad, S. 1999. 'Economic analysis of extraction and processing of forest residues'. The Malaysian Forester, 62(4): pp. 160-86.

Holmes, T.P., Blate, G.M., Zweede, J.C., Pereira, R., Barreto, P., Boltz, F. and Bauch, R. 2002. 'Financial and ecological indicators of reduced impact logging performance in the eastern Amazon'. Forest Ecology \& Management, 163: pp. 93-110.

Jaeger, M., 1999. 'Quantification of forest residues'. The Malaysian Forester, 62(4): pp. 187-203.

Johns, A.D. 1988. 'Effects of selective timber extraction on rain forest structure and composition and some consequences for frugivores and folivores'. Biotropica, 20: pp. 31-6.

Klassen, A.W. 1994. Avoidable logging waste. Report for Office of Agro-Enterprise and Environment. USAID. Jakarta, Indonesia.

Kurniawan, W. 1996. Potensi dan model pendugaan volume limbah penebangan di wilayah kerja HPH PT. Rokan Permai Timber Propinsi Dati I Riau. Skripsi. Jurusan 
Managemen Hutan, Fakultas Kehutanan, Institut Pertanian Bogor. Bogor, Indonesia.

Laser Technology, Inc. 1998. User Manual Impulse LR. Englewood CO, USA. 80 pp.

Machfudh. 2001. General description of the Bulungan Research Forest. ITTO Technical Report Phase I 1997-2001. CIFOR. Bogor, Indonesia. pp. 8-22.

Mathers, N.J. and Xu, Z.H. 2003. 'Solid-state ${ }^{13} \mathrm{C}$ NMR spectroscopy characterization of soil organic matter under two contrasting residue management regimes in a two-year old pine plantation of subtropical Australia'. Geoderma, 114: pp. 19-31.

Muladi, S. 1998. Penelusuran limbah kayu pada kegiatan logging dan upaya pemanfaatannya. Laporan Penelitian. Fakultas Kehutanan, Universitas Mulawarman. Samarinda.

Nzila, J. du D., Bouillet, J.-P., Laclau, P. and Ranger, J. 2002. 'The effects of slash management on nutrient cycling and tree growth in Eucalyptus plantations in the Congo'. Forest Ecology \& Management, 171: pp. 209-21.

Philip, M.S. 1994. Measuring trees and forests. Second edition. CAB International, Wallingford.

Sheil, D., Rajindra, K.P., Basuki, I., van Heist, M., Wan, M., Liswanti, N., Rukmiyati, Sardjono, M.A., Samsoedin, I., Sidiyasa, K., Chrisandini, Permana, E.. Angi, E.M., Gatzweiler, F., Johnson, B. and Wijaya, A. 2004. Mengeksplorasi keanekaragaman hayati, lingkungan, dan pandangan masyarakat lokal mengenai berbagai lanskap hutan. CIFOR. Bogor, Indonesia.
Sist, P. and Bertault, J.G. 1998. 'Reduced impact logging experiments: impact of harvesting intensities and logging techniques on stand damage'. In: Silvicultural research in lowland mixed dipterocarp forest of East Kalimantan. The contribution of STREK project. Chapter 7: pp. 139-61. CIRAD-foret, FORDA, PT. INHUTANI I.

Tetter, D. 1994. Economic Parameter of Logging Waste. NRMP Report No. 44 for Bappenas - Ministry of Forestry, Associates in Rural Development for Office of AgroEnterprise and Environment. USAID, Jakarta, Indonesia.

Trockenbrodt, M., Imiyabir, Z. and Josue, J. 2002. 'Hollow logs and logging residues from Deramakot Forest Reserve, Sabah, Malaysia'. Forest Ecology and Management, 165: pp. 141-50.

Uhl, C. and Vieira, I.C.G. 1989. 'Ecological impacts of selective logging in the Brazilian Amazon: a case study from the Paragominas region of the State of Pará'. Biotropica, 21: pp. 98-106.

Whitmore, T.C. and Sayer, J.A. (eds). 1992. Tropical forest deforestation and species extinction. Chapman and Hall, London. 152 pp.

Yasmi, Y. 2003. 'Understanding conflict in the co-management of forests: the case of Bulungan Research Forest'. International Forestry Review, 5(1): pp. 38-44. 


\section{CHAPTER 10 WILDLIFE CONSERVATION IN BORNEAN TIMBER CONCESSIONS}

Erik Meijaard and Douglas Sheil 


\section{INTRODUCTION}

There is an increasing awareness that wildlife species in Kalimantan can benefit from forests that are managed for sustainable timber extraction (Colón, 1999; Lammertink, 2004b; Sheil et al., 2004). In the last few decades, conservation efforts have focused on strictly protected areas, but recent insights, in common with other areas of the world (e.g. Hulme and Murphree, 2001) have suggested that these reserves are insufficient to protect rare and/or threatened species. The reasons include the fragmentation of the protected area network and its failure to consider the representation and presence of threatened species as key criteria in its planning (Jepson et al., 2002).

Moreover, enforcement within protected areas is weak in many regions, to the extent that forests are disappearing even within these areas (Fuller et al., 2003; Curran et al., 2004), due to a number of socio-economic and political reasons (Kramer et al., 1997; Rijksen and Meijaard, 1999; Jepson et al., 2001, 2002). Ineffective management, however, is a dominant factor. Management, if any, is directed from regional or national offices, but, with insufficient on-theground staff to provide even basic safeguards, many protected areas remain paper parks (cf. Bruner et al., 2001; Rodriguez and RodriguezClark, 2001). Poor political support for active conservation management is a global problem that is only slowly beginning to improve. Thus, conservation remains underfunded (e.g. Balmford and Whitten, 2003) and tax systems providing financial compensation remain undeveloped.

Direct economic benefits, such as timber production or extraction and sale of non-timber forest products, provide an incentive to maintain forests and a way to generate conservation benefits (Salafsky et al., 1994; Shackleton, 2001), especially when various economic and political forces encourage improved management practices. This, and the fact that forest loss threatens both conservation interests and timber production, explains why tropical production forestry and conservation are increasingly finding common ground (e.g. McAlpine et al., 2007), often mediated or prompted by local forest-dependent communities, with mixed success (Morsello, 2006). Whether production forestry has the potential to halt forest decline, or to otherwise benefit conservation, is disputed (Bowles et al., 1998; Lugo, 1999; Putz et al., 2000), but we wish to emphasise the pragmatic ecological basis for involving timber concessions in wildlife conservation.

Many wildlife species in Kalimantan's forests persist at only slightly altered densities in selectively harvested forests, and well-managed production forests can provide adequate habitat for most species (Meijaard et al., 2005, 2006a,b). Still, little is known about how different management approaches affect specific wildlife, and even less about how wildlife conservation might be balanced with commercial production benefits. This is particularly pertinent with increasing control of forests and logging activities in the hands of local authorities. It is at the local level that support for and benefits of conservation need to be mobilised.

Here we present a summary review of the impacts of logging on wildlife as previously published in English (Meijaard et al., 2005) and Indonesian (Meijaard et al., 2006a). We justify and outline practical recommendations for improved forest management that go beyond current standards.

\section{A CONSERVATION OPPORTUNITY}

While many conservation NGOs have in the past condemned logging, the situation is changing. This trend reflects increasing collaboration between timber managers and conservationists, a process clearly seen in Borneo. Why is this?

About $10 \%$ of Borneo is under strict protection. If only this forest is maintained, habitat loss and fragmentation will severely impact many rare and wide-ranging species such as the clouded leopard, Neofelis diardi, or the endangered Storm's stork (Ciconia stormi). Any additional forest offers numerous potential conservation benefits.

With about $20,000 \mathrm{~km}^{2}$ or half of Borneo's remaining forests under active forestry concessions, these areas are of key conservation importance. For example, we estimate that $75 \%$ of the Bornean orangutans (Pongo pygmaeus) occur in forest concessions. 
Given political realities, and rapid deforestation due to conservation for other (non-forest) land uses, extensive forest areas will endure only if they yield economic benefits. Production forestry in Borneo's rainforests is selective - only a few trees are removed from each hectare - so what remains is still forest. For forest fauna, this logged forest is considerably better than no forest.

Strict protection status currently makes little difference to forest loss in Kalimantan (Curran, et al., 2004). This reflects the challenge of patrolling and managing extensive areas with limited resources. In contrast, many timber companies have the capacity to manage and protect large areas of forest - and it makes good business sense to do so.

Timber companies wish to access the burgeoning 'green market' in certified timber. Four Indonesian natural forest concessions have already achieved internationally recognised Forest Stewardship Council standards - and many more are trying to. This demonstrates both ability and a commitment to conservationfriendly management. Our monitoring of one of these concessions implies forest losses below $0.1 \%$ per year (unpublished data), while the Kalimantan average is $2 \%$ (Fuller et al., 2004).

So it makes sense for those who wish to maintain large forest landscape in Borneo to work with logging companies and advise them on how to improve the value of the forest for conservation (Meijaard and Sheil, 2007a,b,c). What knowledge and advice can we offer?

\section{METHODS}

We compiled and analysed data sets on how production forestry affects forest wildlife throughout Borneo. The review had to be wider than just Malinau and even Kalimantan because of the scarcity of work from these specific areas. We reviewed all available literature (published and unpublished) on Bornean wildlife species, including mammals, bird, reptiles and amphibians, and consulted widely with local and international experts.

We analysed 282 publications arising from Borneo-based studies (Meijaard et al., 2005;
Meijaard and Sheil, 2007a,c; Meijaard et al., 2007), and a similar number of relevant publications based on research elsewhere in south-east Asia (Meijaard et al., 2005). For each species study, we selected certain species and assessed their tolerance to logging, both the direct impacts and related effects that often follow, such as hunting and forest fragmentation. The process also had to rank the probable accuracy and robustness of the original reports, as in many instances different studies found different impacts of logging on the same species. For example, one study in a particular region of Borneo might have reported a decline in a certain species after logging, but another study using a different approach and in a different region may have concluded there was no effect, or perhaps even an increase in abundance. Thus, results for the same species are not consistent. Indeed, only $33 \%$ of the species reviewed had a consistent pattern across all studies (i.e. either only decreased, or increased, or no change), although this includes some species for which there was only one study.

For those species with inconsistent results across studies, we generally considered the findings from studies that employed large sample sizes and longer-term monitoring over those at a single site and a single low-intensity survey. None the less, the percentage of studies in the various categories sums added up to more than $100 \%$ because of the different findings between different studies on the same species. Despite this, we have successfully, for the first time, provided an overview of Bornean wildlife's sensitivity to logging, including common traits among species that are either negatively or positively affected (Meijaard et al., 2007). On this basis, the general ecological effects of productive forestry and different wildlife management options can be examined, and recommendations developed to improve forest management. As part of this process, we considered species-specific habitat requirements, allowing us to give particular management recommendations to protect these forest attributes (an overview of the process can be found in Sheil and Meijaard, 2005).

In considering the impacts, one needs to note that throughout most of the region, logging is selective: only commercial species over a set diameter limit (usually $>50 \mathrm{~cm} \mathrm{dbh}$ ) are removed. Various management stages are followed, to 
a greater or lesser extent, to avoid excessive damage to the remaining forest, starting with harvest planning, road and skid trail design, and tree-felling procedures commonly referred to as reduced impact logging (RIL) (see Priyadi, this volume).

\section{Assessment of species' tolerance to logging}

\section{General patterns}

Our review indicated that out of the 64 mammal and bird species investigated in detail, 23\% increased by $>20 \%$ in density following logging, $46 \%$ were relatively neutral $(<20 \%$ change), and $42 \%$ declined significantly ( $>20 \%$ decline). Our literature review revealed that none of the species studied became locally extinct due to logging, at least not within the investigation period (typically $<3$ years). We did not choose our test species objectively, but depended on the information available and thus the original researchers' choice. Each study has its specific context, design, limitations and associated uncertainties, which makes generalisations somewhat problematic. Still, the percentages give some indication of how logging affects Bornean vertebrate fauna, with probably less than half the species showing a clearly negative impact on abundance, but without local extinction.

We do not wish to downplay the impact of timber harvesting on wildlife and recognise that methodological uncertainties remain, but we do point out that the negative effects are less than commonly assumed. General and specific patterns in tolerance provide a basis for developing wildlife-friendly guidelines for forest management.

Our meta-analysis identified patterns among species with different logging tolerance levels. Intolerant mammals tend to have narrow ecological niches, and many have specialist feeding habits, i.e. strictly frugivorous, carnivorous or insectivorous. They appear to be specialised to live in particular forest strata, especially ground or upper canopy levels, rather than ranging through all levels. In contrast, logging-tolerant mammals are herbivorous or more omnivorous. Many of these species live in the lower vegetation strata, although some are found at all levels.
Birds show similar relationships between widths of ecological niches and tolerance (e.g. Lambert and Collar, 2002), with canopy nectarivores and generalist frugivore/insectivores increasing after logging (Johns, 1989; Lambert, 1992; Zakaria, 1994; Johns, 1996). Specialised insectivores in the lower vegetation strata, on the other hand, appear to have low tolerance to logging-related disturbance. Amphibians seem to cope relatively well with the effects of reduced impact logging, with data from Sabah province suggesting that such methods may result in greater diversity than in unlogged forests (but note that the long-term effects on forest species of having more nonforest species present is unknown) (Wong, 2003; undated). Conventional logging, especially where this leads to a much reduced leaf-litter layer, leads to sometimes significant declines in amphibian diversity and abundance over the period of study (Iskandar, 1999; Wong, 2003).

Finally, our review suggested that a few fish species such as the bottom-dwelling Gastromyzon spp. and Garra borneensis, and herbivorous or frugivorous Lobocheilos bo, Osteochilus chinni and Tor spp., are sensitive to logging (Rachmatika et al., 2004). However, even these species can quickly recolonise rivers after logging ceases and if sedimentation is controlled and some local populations remain (Martin-Smith, 1998).

As opposed to the direct effects of timber extraction, fragmenting large contiguous forests into much smaller blocks seems to affect a much broader range of species. This is the case at least for birds - omnivores, insectivores, frugivores and nectarivores - and virtually all species negatively affected by logging (but note that some birds benefit from logging and fragmentation, especially generalist, non-forest species) (Lambert and Collar, 2002). No detailed studies have been conducted on how fragmentation affects Sundaic mammals, although a study by Brook et al. (2003) linked mammal extinctions on Singapore to dwindling habitat. Roads in concessions also notably fragment the forest, though many, but not all, species easily cross these roads; this is a topic that warrants further investigation.

Hunting appears to be the final major factor determining wildlife densities in forest that has been made more accessible (via logging roads) 
or open through selective logging. Naturally this is especially so for the specific species targeted by hunters. Thus, there is a synergistic negative impact between selective logging and hunting on certain species, such as those most sought after for food or trade, including pigs, deer, muntjacs, monkeys, porcupines, pheasants, hornbills and turtles. However, snaring kills many non-target species as well. The impacts of post-logging hunting has been extensively documented in Sarawak (Malaysian Borneo) and on the African continent (e.g. Wilkie et al., 2000), where a clear link exists between timber harvesting and hunting (e.g. Bennett and Gumal, 2001). The effects of hunting have also been reported from Kalimantan (Nijman, 2004, 2005; Marshall et al., in press) and are inferred from first-hand observation in areas with high and low hunting pressures (Meijaard, pers. obs.).

\section{Species-specific patterns}

Besides the general patterns in species' tolerance, logging affects particular species in specific ways. For instance, logging in Borneo primarily targets dipterocarp species, and it would be expected that vertebrates specifically depending on these and other commercial timber species would be disproportionately affected. Few vertebrates probably have an obligatory relationship with dipterocarps, although clearly seed eaters such as bearded pigs (Sus barbatus), Muntiacus species, porcupines, certain squirrels and some hornbills use these trees at least some of the time. Retaining very large dipterocarp trees will enhance forest regeneration by providing seeds beyond what seed eaters consume. Such large trees also contribute disproportionately to the total amount of dead wood available in a forest (Grove, 2001), and dead wood provides a key habitat element for many Bornean species (Bernard, 2004). Local people have suggested that large dipterocarp trees attract seed eaters (Limberg et al., this volume) and such waste wood can be utilised and economically valuable (Iskander et al., this volume).

Large-stemmed trees provide many species with hollows for nesting and storing food. The helmeted hornbill (Rhinoplax vigil), for instance, appears to prefer big $(\mathrm{dbh}>105 \mathrm{~cm})$ dipterocarp species (Hopea spp. and Shorea spp.) for nesting (Thiensongrusamee et al., 2001). The distribution and determinants of tree hollows have been little studied, but hollows appear more likely in large-stemmed (mostly dbh $>60 \mathrm{~cm}$ ) species with relatively light timber and susceptible to heart-rot. Initially, after limited timber removal, remaining large and damaged trees may be prone to forming cavities, but this may change if larger trees are ultimately removed, perhaps over several cutting cycles.

Some trees, most notably figs (Ficus spp.), are especially important for wildlife, as stands provide fruit throughout the year (Jordano, 1983; Lambert, 1989b, 1989a, 1989c, 1990, 1991; Heydon and Bulloh, 1997; O'Brien, 1998; Kinnaird et al., 1999) and fulfill vital nutritional needs such as the calcium needed by vertebrates living on otherwise mineral-poor diets (see O'Brien et al., 1998). Depending on the species, fig trees per se do not usually fruit continuously and so a large area with sufficient trees and variety of species is needed for a yearround supply. Several studies have reported a decline in fig densities following logging (Johns, 1983; Leighton and Leighton, 1983; Lambert, 1990; Heydon and Bulloh, 1997) indicating that logging lowers the forest's carrying capacity for species primarily feeding on these fruits. Wild bananas (Musa spp.) are another possible yearround fruit source, but their importance for wildlife remains unstudied. These pioneer plants are often common in disturbed areas and may reduce logging's impact on frugivores such as various civets and macaques.

Many species are presumed to depend on particular structures for perching, foraging, breeding or resting. Woodpeckers have been studied very well in this respect, and foraging substrates for most woodpecker species are well known (Styring, 2002; Styring and Ickes, 2003; Lammertink, 2004b). However, we have limited knowledge on the structural requirements for most other species. Logging affects a forest's three-dimensional structure in many ways, and we cannot generalise here on the effects on any particular species. Some species, like deer or certain frogs and toads, will benefit from gaps being created, which could in turn provide extra food for carnivores. Other species will fail to find food in gaps - for example interior forest bats such as Hipposideros spp. and Rhinolophus spp. (see Kingston et al., 2003). Some species, such as some small rodents, benefit from the denser, more complex understorey conditions that follow logging (Bernard, 2004), while 
other creatures seem to require the orderly and open structure of primary forests, such as forest owls like Otus rufescens and frogmouths Batrachostomus spp. Again, the more adaptable a species is in its behaviour, the more likely it can cope with the effects of logging.

\section{How can forests be managed to ensure higher compatibility between wildlife conservation and timber harvesting?}

What are the implications of our findings for timber-concession management? Our data show that although many species experience density declines following logging, virtually all can survive the initial effects. Unfortunately, many of the most adversely affected species are also the most endangered in terms of the IUCN (2003) Red List criteria (Meijaard and Sheil, 2007a). It would be beyond the ability of concession managers to protect all the ecological needs of the vertebrate species most affected by timber harvesting, but some simple improvements could go a long way towards reducing impacts on the most threatened species, as listed by Meijaard and Sheil (2007a). Wildlife-friendly timber management objectives would most likely include:

- Generally reducing impacts such as road building, gap creation and slashing climbers and ground vegetation. Experiments in East Kalimantan have demonstrated that logging damage can be significantly reduced only under a moderate felling intensity of 8-9 trees/hectare, but 10-11 trees/hectare is common practice (Sist, 2001; Sist et al., 2003 b). Limiting harvesting to trees $>100$ $\mathrm{cm}$ dbh should not significantly constrain production (Sist et al., 2003a) and it would also provide ecologically important oldgrowth stems while reducing damage. Lighter machinery could also be used if loggers avoid removing the very largest stems. Reducing overall impacts requires careful planning and execution, but need not result in reduced timber yields.

- Leave dead or partially dead trees intact as they provide vital habitat for hole-nesting birds, various invertebrates and hollows for vertebrates for breeding and storing food.

- Leave large fig (Ficus) trees in situ. Fig trees are a primary food source for many species, and the various species come into fruit at different times, resulting in a more-or-less year-round food source.
- Safeguarding no-logging and no-hunting zones. Areas zoned for protection must be respected and maintained. Ideally these should be planned with some degree of connectivity in the forest cover between different concessions. In areas where logging does occur, the no-hunting regulations should be actively enforced, with the necessary support from local stakeholders, as well as local authorities and NGOs. Postlogging hunting is undoubtedly one of the major threats to a range of species. Species that are already on national or regional lists for protection must be actively monitored and protected. Culturally important species may be used but according to off-take levels agreed by local stakeholders and regularly reviewed based on monitoring.

- Applying and abiding by existing laws and regulations with respect to (i) prevention of activities detrimental to protected species (Act 5, 1990), and (ii) exclusion zones around streams to safeguard water yield and quality.

Besides these general provisions at the forest scale, there are a number of issues relating to specific species, which we outline below.

\section{Species-specific issues}

So far, we have not incorporated specific advice on how to protect 'important' local wildlife species in our recommendations. 'Importance' is difficult to define and depends on the stakeholders' perspectives. Still, one approach is to consider national and international protection and conservation status, the degree of local use and cultural significance, and its range. Thus, we identified the highest priority species using the IUCN status of Bornean species (IUCN 2003), their protection status under Indonesian law (Noerdjito and Maryanto, 2001) and their importance to local communities, based on several published data sets (Puri, 1997; Wadley et al., 1997; Puri, 2001; Sheil et al., 2002). We realise that this list does not include all priority species, but it provides guidance for what we consider to be the most important conservation targets, while also addressing local community requirements (see also Meijaard et al., 2006b).

Primates. Especially Bornean gibbon (Hylobates muelleri), Hose's leaf monkey (Presbytis hosei), white-fronted leaf monkey ( $P$. frontata), slow loris (Nycticebus coucang), pig-tailed macaque 
(Macaca nemestrina) and Bornean orangutan (Pongo pygmaeus). Hunting is the main threat to these species in timber concessions (Wadley et al., 1997; Nijman, 2004; Marshall et al., in press), but extensive clearing, canopy and interior forest disturbance/loss also take their toll. Because of their protected status, we strongly recommend a complete prohibition on hunting these species in concession areas. The only exception is $M$. nemestrina which is not protected; for this species we recommend setting quotas in designated hunting zones, while monitoring the impact on the population. Self monitoring of hunting by communities, even in protected areas, is increasingly successful in controlling the impacts (Noss et al., 2004). Because orang-utans attract global interest, a concessionaire could benefit from having this species in their concession. If fruit trees are retained and no hunting occurs, a surviving orang-utan population could be of considerable public relations' value.

Ungulates. These include the rare Bornean banteng (Bos javanicus), sambar (Cervus unicolor) and muntjaks (Muntiacus spp.). All these species are protected, although the local hunting pressure on them is high (Puri, 1994; Bennett et al., 2000). These species, except for the Bornean endemic muntjak, Muntiacus atherodes, should benefit from the more open conditions created following road building and timber extraction (see Meijaard et al., 2005). They are also attracted to fodder provided by the herbaceous vegetation common on roadsides. This, however, makes them very vulnerable to hunting, and we recommend that all hunting of these animals is prohibited, unless a legal agreement can be obtained from the Ministry of Forestry allowing an annual take-off quota, along with appropriate monitoring and enforcement. Other ungulates, like mouse-deer (Tragulus spp.) and pigs (Sus barbatus), are even more commonly hunted, but generally appear to survive in timber concessions as long as forests are well managed, thus securing sufficient food resources.

Civets. Logging appears negatively to affect some of these species, such as the carnivorous banded palm civet (Hemigalus derbyanus) and other non-generalist feeders (see Meijaard et al., 2005). Still, we regularly encounter most lowland civet species, apart from banded linsang (Prionodon linsang) and binturong (Arctictis binturong), in well-managed forestry concessions. This suggests that the more common species do not require special management attention. The banded linsang and binturong are protected in Indonesia, and all hunting should be prohibited. Because civets are occasionally hunted for food and because they are considered livestock pets, we recommend including civets in a hunting monitoring programme.

Cats. Logging's impact on tropical cats remains unstudied. From our personal observations, timber extraction alone does not appear significantly to affect cats. We recognise, though, that this observation may be biased by frequent cat sightings along logging roads, to which they may be attracted by good hunting conditions. Also cats are more easily seen along roads. Hunters target cats for their pelts, despite their protected status, and hunting control in concessions is important. Including cats in a simple monitoring programme - for instance by noting all records on logging roads - enables the concession holder to monitor temporal and spatial changes in populations. Cats are also popular, and having reliable sighting opportunities may provide incentives for eco-tourism, as mentioned above for large primates. Establishing where the species occurs in a logging concession would be a primary objective. Sightings and signs should be reported to biologist monitors or concession managers.

Malayan sun bear. Timber extraction seems to have a generally negative impact on sun bears, although they can survive in high densities in lightly disturbed forests (Augeri, 2004; Meijaard et al., 2005). Hunting associated with logging can have significant impacts on populations (Meijaard, 1999). The species is protected in Indonesia, but targeted by hunters for pelts, teeth, claws, meat and gall bladder, so hunting should be prohibited in timber concessions.

Squirrels. Squirrels vary considerably in the extent to which they cope with logging (see Meijaard et al., 2005). Some species from the Callosciurus group seem well-adapted to disturbed environments, whereas specialist frugivore or insectivore feeders like some Sundasciurus, Ratufa and Rhinosciurus species decline in logged forests. Only Lariscus insignis is protected in Indonesia, although hunting does not seem to be a major threat. We do not 
recommend any species-specific management, apart from a hunting ban on protected species.

Bats. Bats are pollinators and seed dispersers of considerable economic and ecological importance. Their tolerance of timber extraction depends on their ecology. Bats feeding in open areas are favoured, whereas small forest bats disappear rapidly after logging. Most species remain poorly known, and no bats are protected in Indonesia. We therefore do not recommend species-specific management. Protection of roosting sites like naturally fallen trees, caves and rock faces should be promoted.

Hornbills. Of this species, the helmeted hornbill (Buceros vigil), rhinoceros hornbill (B. rhinoceros) and black hornbill (Anthracoceros malayanus) are particularly affected by hunting, loss of breeding space and loss of food sources (Bennett et al., 1997; Bennett and Gumal, 2001). Because these birds are protected by Indonesian law, we recommend prohibiting all hunting in timber concessions. We also recommend retaining very large trees and fruit trees. If hornbill nests are found in trees selected for logging, this means the tree is certainly hollow and it should therefore be left standing. If a nesting tree needs to be cut for other reasons such as road building, this should be done after young birds have left the nest. Hornbill nesting can occur throughout the year but, in Borneo, seems to be concentrated between January and April (see Meijaard et al., 2005, for an overview). The nesting cycle is, at most, 130 days, and we recommend that if a tree with an active nest needs to be cut, this should be planned some three months beforehand, allowing the birds time to leave.

Pheasants. Bulwer's pheasant (Lobiophasis bulweri), the crestless fireback (Lophura erythrophthalma) and the great argus (Argusianus argus) are primarily affected by hunting, loss of food sources such as fallen fruit and invertebrates in leaf litter, and human disturbance (see Meijaard et al., 2005). Counteraction is best achieved by setting aside sufficiently large areas in which populations of these birds are protected, with adequate controls. If areas in concessions are protected for pheasants, the areas should be sufficiently large and include undisturbed sections of hill forest and alluvial valleys.
Storm's stork (Ciconia stormi) is an endangered species with an estimated global population of less than 1,000 individuals (BirdLife International 2001). It is primarily restricted to unlogged or lightly logged lowland forests with very little human disturbance. If this species occurs in a concession, we recommend that the concessionaire contact local NGOs or research institutions for specific advice on how to manage these birds. It is protected and so no hunting or other detrimental activities are allowed.

Straw-headed bulbul (Pycnonotus zeylanicus). This species is much sought after as a caged bird (Holden, 1997 in BirdLife International 2001). Populations are in severe decline; it has been reported that 'it has been virtually exterminated as a wild bird' in Indonesia (Holmes, 1995 in BirdLife International 2001). It is not protected in Indonesia, but this species needs active protection: collection in concessions must be forbidden.

Great slaty woodpecker (Mulleripicus pulverulentus). This species is found in level lowland forests; its density is reduced $>80 \%$ in logged forest compared with primary forests (Lammertink, 2004a). It requires large-diameter, live trees to forage for stingless bee, ant and termite nests located in natural cavities in large branches and tree trunks. Retaining largediameter, live trees, dipterocarps and other tree species in level lowland forests will reduce severe declines in woodpeckers after logging.

Turtles. Over-collection threatens the Malayan flat-shelled turtle (Notochelys platynota), brown giant tortoise (Manouria emys) and possibly also the common soft-shell turtle (Amyda cartilaginea). Although listed as seriously threatened with extinction (IUCN, 2003), these species are not protected by Indonesian law. A primary objective should be to establish densities and numbers and work towards a sustainable level of harvesting.

Carps (Tor spp.). These fish require clear water, are dependent on forest vegetation, are easily caught, have a relatively low reproductive rate and are keenly sought. Pangasius spp. are migratory, using upstream spawning areas. Pangasius spp. forms seasonal aggregations when breeding, which allows easy over-fishing and 
this species complex has become very rare in Malinau. Tor spp. are herbivores/frugivores and are believed to be associated with Dipterocarpus or Ficus trees growing along the bank, and with algae growing in clear water on unsilted river beds. A primary objective should be to establish densities and numbers for the various species and work towards a sustainable harvesting level. Furthermore, careful stream management should ensure clear streams so that logging, road construction or other developments do not severely affect carp populations (Rachmatika et al., 2004).

\section{CONCLUSION}

We initiated this research because sustainable forestry concerns are primarily focused on maintaining timber production, with only a secondary focus on institutional issues, conservation dimensions and forestry's socio-economic aspects. Few practical recommendations exist on how to deal with wildlife issues. Surprisingly, despite decades of zoological research on Borneo, almost none of this research is reflected in best forestry practice (for a discussion see Meijaard and Sheil, 2007b). Our review indicates firstly that the negative impact of logging on species is not uniform, and secondly that there are ways in which sustainable management can be seen as contributing to conservation rather than as a threat. Forestry concessions are an essential part of the total forest area needed to guarantee the long-term survival of Borneo's wildlife.

Based on our review, we sought recommendations and guidelines that would increase the compatibility between forestry and wildlife conservation. Although we were struck by the lack of detailed recommendations (Meijaard and Sheil, 2007b), we were convinced that many improvements could and should be included in concession practices. If willing partners can be found in the logging industry, facilitated and monitored by local government, implementing our recommendations could lead to considerable conservation benefits. These successes will show other forestry concessions and governments that wildlife conservation and forestry can be compatible in the south-sast Asian tropics.

\section{ACKNOWLEDGEMENTS}

Many thanks to Claire Miller, Charlie Shackleton and anonymous reviewers for help in improving previous versions of this text.

\section{REFERENCES}

Augeri, D. 2004. Effects of disturbance on Malayan Sun Bear habitat use. Paper presented at the International Conference on Conservation Science, Cambridge, UK.

Balmford, A. and Whitten, T. 2003. 'Who should pay for tropical conservation, and how could the costs be met?' Oryx 37: pp. 238-50.

Bennett, E.L. and Gumal, M.T. 2001. 'The inter-relationships of commercial logging, hunting and wildlife in Sarawak, and recommendations for forest management'. In R. A. Fimbel, Grajal, A. and Robinson, J.G. (eds). The Cutting Edge: Conserving Wildlife in Logged Tropical Forest. Columbia University Press, New York, pp. 359-74.

Bennett, E.L., Nyaoi, A.J. and Sompud, J. 1997. 'Hornbills Buceros spp. and culture in Northern Borneo: Can they continue to coexist?' Biological Conservation 82: pp. 41-6.

Bennett, E.L., Nyaoi, A.J. and Sompud, J. 2000. 'Saving Borneo's bacon: The sustainability of hunting in Sarawak and Sabah'. In J.G. Robinson and E.L. Bennett (eds), Hunting for Sustainability in Tropical Forests. Columbia University Press, New York, pp. 305-24.

Bernard, H. 2004. 'Effects of selective logging on microhabitat-use patterns of non-volant small mammals in a Bornean tropical lowland mixed-dipterocarp forest'. Nature and Human Activities 8: pp. 1-11.

BirdLife International. 2001. Threatened birds of Asia: the BirdLife International Red Data Book. Birdlife International, Cambridge, United Kingdom.

Bowles, I.A., Rice, R.E., Mittermeier, R.A. and da Fonseca, G.A.B. 1998. 'Logging and tropical forest conservation'. Science 280: pp. 1899900.

Brook, B.W., Sodhi, N.S. and Ng, P.K.L. 2003. 'Catastrophic extinctions follow deforestation in Singapore'. Nature 424: pp. 420-3. 
Bruner, A.G., Gullison, R.E., Rice, R.E. and da Fonseca, G.A.B. 2001. 'Effectiveness of parks in protecting tropical biodiversity'. Science 291: pp. 125-8.

Colón, C.P. 1999. Ecology of the Malay Civet (Viverra tangalunga) in a logged and unlogged forest in Sabah, East Malaysia. Fordham University USA.

Curran, L.M., Trigg, S.N., McDonald, A.K., Astiani, D., Hardiono, Y.M., Siregar, P., Caniago, I. and Kasischke, E. 2004. 'Lowland forest loss in protected areas of Indonesian Borneo'. Science 303: pp. 1000-3.

Fuller, D.O., Jessup, T.C. and Salim, A. 2003. 'Loss of forest cover in Kalimantan, Indonesia, since the 1997-1998 El Niño'. Conservation Biology 18: pp. 249-54.

Grove, S.J. 2001. 'Extent and composition of dead wood in Australian lowland tropical rainforest with different management histories'. Forest Ecology \& Management 154: pp. 35-53.

Heydon, M.J. and Bulloh, P. 1997. 'Mousedeer densities in a tropical rainforest: the impact of selective logging'. Journal of Applied Ecology 34: pp. 484-96.

Hulme, D. and Murphree, M.W. (eds). 2001. African wildlife and livelihoods: the promise and performance of community conversation. James Curry, Oxford.

Iskandar, D.T. 1999. Final Report: Training on "Monitoring Methods in Amphibians and Reptiles Fauna" at Soraya and Gunung Air Station, Leuser National Park. Institute of Technology, Bandung, Indonesia.

IUCN. 2003. IUCN Red List of Threatened Species. http://www.redlist.org/

Jepson, P., Momberg, F. and van Noord, H. 2002. 'A review of efficacy of the protected area system of East Kalimantan Province'. Natural Areas Journal 22: pp. 28-42.

Jepson, P., Jarvie, J.K., MacKinnon, K. and Monk, K.A. 2001. 'The end for Indonesia's lowland forests?' Science 292: pp. 859-61.

Johns, A. 1983. Ecological effects of selective logging in a West Malaysian rainforest. University of Cambridge, Cambridge, UK.

Johns, A. 1989. 'Recovery of a peninsular Malaysian avifauna following selective timber logging: the first twelve years'. Forktail 4: pp. 89-105.

Johns, A. 1996. 'Bird population persistence in Sabahan logging concessions'. Biological Conservation 75: pp. 3-10.
Jordano, P. 1983. 'Fig-seed predation and dispersal by birds'. Biotropica 15: pp. 13841.

Kingston, T., Francis, C.M., Akbar, Z. and Kunz, T.H. 2003. 'Species richness in an insectivorous bat assemblage from Malaysia'. Journal of Tropical Ecology 19: pp. 67-79.

Kinnaird, M.F., O'Brien, T.G. and Suryadi, S. 1999. 'Importance of figs to Sulawesi's imperiled wildlife'. Tropical Biodiversity 6: pp. 5-18.

Kramer, R., van Schaik, C. and Johnson, J. (eds). 1997. Last stand. Protected areas and the defence of tropical biodiversity. Oxford University Press, Inc., New York, USA.

Lambert, F.R. 1989a. 'Fig eating birds in a Malaysian lowland rainforest'. Journal of Tropical Ecology 5: pp. 401-12.

Lambert, F.R. 1989b. 'Daily ranging behaviour of three tropical frugivores'. Forktail 4: pp. 107-16.

Lambert, F.R. 1989c. 'Fig-eating and seed dispersal by pigeons in a Malaysian lowland forest'. Ibis 131: pp. 512-27.

Lambert, F.R. 1990. 'Some notes on fig-eating by arboreal mammals in Malaysia'. Primates 31: pp. 453-8.

Lambert, F.R. 1991. 'The conservation of fig-eating birds in Malaysia'. Biological Conservation 58: pp. 31-40.

Lambert, F.R. 1992. 'The consequences of selective logging for Bornean lowland forest birds'. Philosophical Transactions of the Royal Society, London B 335: pp. 443-57.

Lambert, F.R. and Collar, N.J. 2002. 'The future for Sundaic lowland forest birds: longterm effects of commercial logging and fragmentation'. Forktail 18: pp. 127-46.

Lammertink, M. 2004a. 'Grouping and cooperative breeding in the Great Slaty Woodpecker'. Condor 106: pp. 309-19.

Lammertink, M. 2004b. 'A multiple-site comparison of woodpecker communities in Bornean lowland and hill forests'. Conservation Biology 18: pp. 746-57.

Leighton, M. and Leighton, D.R. 1983. 'Vertebrates' responses to fruiting seasonality within a Bornean rain forest'. In Sutton, S.L., Whitmore, T.C. and Chadwick, A.C. (eds), Tropical rain forest: Ecology and Management, 2 ed. Blackwell Scientific Publications, Oxford, pp. 181-96. 
Lugo, A.E. 1999. 'Will concern for biodiversity spell doom to tropical forest management?' Science of the Total Environment 240: pp. 123-31.

Marshall, A.J., Nardiyono, L.M., Engström, B., Pamungkas, J., Palapa, Meijaard, E. and Stanley, S.A. In press. 'The blowgun is mightier than the chainsaw in determining population density of Bornean orangutans (Pongo pygmaeus morio) in the forests of East Kalimantan'. Biological Conservation.

Martin-Smith, K.M. 1998. 'Effects of disturbance caused by selective timber extraction on fish communities in Sabah, Malaysia'. Environmental Biology of Fishes 53: pp. 15567.

McAlpine, C.A., Spies, T.A., Norman, P. and Peterson, A. 2007. Conserving forest biodiversity across multiple land ownerships: Lessons from the Northwest Forest Plan and the Southeast Queensland regional forests agreement (Australia)'. Biological Conservation 134: pp. 580-92.

Meijaard, E. 1999. 'Human-imposed threats to sun bears in Borneo'. Ursus 11: pp. 18592.

Meijaard, E. and Sheil, D. 2007a. 'The persistence and conservation of Borneo's mammals in lowland rain forests managed for timber: observations, overviews and opportunities'. Ecological Research [in press].

Meijaard, E. and Sheil, D. 2007b. 'A logged forest in Borneo is better than none at all'. (correspondence) Nature, 446: p. 974.

Meijaard, E. and Sheil, D. 2007c. 'Is wildlife research useful for wildlife conservation in the tropics? A review for Borneo with global implications'. Biodiversity \& Conservation. 16: pp. 3053-65

Meijaard, E., Sheil, D., Marshall, A.G. and Nasi, R. 2007. 'Phylogenetic age is positively correlated with sensitivity to timber harvest in Bornean mammals'. Biotropica. [in press].

Meijaard, E., Sheil, D., Rosenbaum, B., Iskandar, D., Augeri, D., Setyawati, T., Duckworth, W., Lammertink, M.J., Rachmatika, I., Nasi, R., Wong, A., Soehartono, T., Stanley, S., Gunawan, T. and O'Brien, T. 2006a. Hutan pasca pemanenan: melindungi satwa liar dalam kegiatan hutan produksi di Kalimantan. CIFOR, ITTO and UNESCO, Bogor, Indonesia.
Meijaard, E., Sheil, D., Nasi, R. and Stanley, S.E. 2006b. 'Wildlife conservation in Bornean timber concessions'. Ecology and Society 11: p. 47, (11p.) [online] URL: http://www. ecologyandsociety.org/vol11/iss 1/art47/

Meijaard, E., Sheil, D., Rosenbaum, B., Iskandar, D., Augeri, D., Setyawati, T., Duckworth, W., Lammertink, M.J., Rachmatika, I., Nasi, R., Wong, A., Soehartono, T., Stanley, S. and O'Brien T. 2005. Life after logging: reconciling wildlife conservation and production forestry in Indonesian Borneo. CIFOR, WCS and UNESCO, Bogor, Indonesia.

Ministry of Forestry. 1990. Act of the Republic of Indonesia No. 5 of 1990 Concerning Conservation of Living Resources and Their Ecosystems. Ministry of Forestry of the Republic of Indonesia.

Morsello, C. 2006. 'Company-community nontimber forest product deals in the Brazilian Amazon: a review of opportunities and problems'. Forest Policy \& Economics 8: pp. 485-94.

Nijman, V. 2004. 'Habitat segregation in two congeneric hawk-eagles (Spizaetus bartelsi and S. cirrhatus) in Java, Indonesia'. Journal of Tropical Ecology 20: pp. 105-11.

Nijman, V. 2005. 'Decline of the endemic Hose's langur Presbytis hosei in Kayan Mentarang National Park, East Borneo'. Oryx 39: pp. 223-6.

Noerdjito, M. and Maryanto, I. 2001. Jenis-jenis hayati yang dilindungi perundang- undangan Indonesia. Balitbang Zoologi (Museum Zoologicum Bogoriense), Puslitbang - LIPI, and The Nature Conservancy, Cibinong, Indonesia.

Noss, A.J., Cuellar, E. and Cuellar, R.L. 2004. 'An evaluation of hunter self-monitoring in the Bolivian Chaco'. Human Ecology 32: pp. 685-702.

O'Brien, T. G. 1998. 'What's so special about figs?' Nature 392: p.128.

O'Brien, T.G., Kinnaird, M.F., Dierenfeld, E.S., Conklinbrittain, N.L., Wrangham, R.W. and Silver, S.C. 1998. 'What's so special about figs?' Nature 392: p. 668.

Puri, R.K. 1994. 'A deadly dance of deception: Hunting knowledge of the Penan Benalui of East Kalimantan, Indonesia'. 3rd Biennial International Conference of the Borneo Research Council. Borneo Research Council, Pontianak, West Kalimantan, Indonesia. 
Puri, R.K. 1997. Hunting knowledge of the Penan Benalui of East Kalimantan, Indonesia. Department of Anthropology. University of Hawaii.

Puri, R.K. 2001. Bulungan ethnobiology handbook. A field manual for biological and social science research on the knowledge and use of plants and animals among 18 indigenous groups in northern East Kalimantan. Center for International Forestry Research, Bogor, Indonesia.

Putz, F.E., Redford, K.H., Fimbel, R., Robinson, J.G. and Blate, G.M. 2000. Biodiversity conservation in the context of tropical forest management. WCS (Wildlife Conservation Society) and World Bank Environment Department, Biodiversity Series, Impact Studies, Paper Number 75. World Bank, Washington, D.C., USA.

Rachmatika, I., Nasi, R. and Sheil, D. 2004. Fish fauna in Bulungan Research Forest (BRF), Malinau, East Kalimantan. CIFOR, Bogor, Indonesia.

Rijksen, H.D. and Meijaard, E. 1999. Our vanishing relative. The status of wild orangutans at the close of the twentieth century. Kluwer Academic Publishers, Dordrecht, The Netherlands.

Rodriguez, J.P. and Rodriguez-Clark, K.M. 2001. 'Even "paper parks" are important'. Trends in Ecology \& Evolution 16: p. 17.

Salafsky, N., Dugelby, B.L. and Terborgh, J.W. 1994. 'Can extractive reserves save the rain forest? An ecological and socioeconomic comparison of non-timber forest product extraction systems in Peten, Guatemala, and West Kalimantan, Indonesia'. Biological Conservation 7: pp. 39-52.

Shackleton, C.M. 2001. 'Re-examining local and market orientated use of wild species for the conservation of biodiversity'. Environmental Conservation, 28: pp. 270-8.

Sheil, D. and Meijaard, E. 2005. 'Seeking life after logging: Reconciling wildlife conservation and production forestry in Indonesian Borneo'. Tropical Forest Update 15: pp. 12-15.

Sheil, D., Nasi, R. and Johnson, B. 2004. 'Ecological criteria and indicators for tropical forest landscapes: Challenges in the search for progress'. Ecology and Society 9: article 7. http://www.ecologyandsociety.org/vo/9/ iss $1 /$ art7
Sheil, D., Puri, R.K., Basuki, I., van Heist, M., Syaefuddin, Rukmiyati, Sardjono, M.A., Samsoedin, I., Sidiyasa, K., Chrisandini, Permana, E., Angi, E.M., Gatzweiler, F. and Wijaya, A. 2002. Exploring biological diversity, environment and local people's perspectives in forest landscapes. Report written with help from the people of Paya Seturan, Long Lake, Rian, Langap, Laban Nyarit, Long Jalan, Lio Mutai and Gong Solok. Center for International Forestry Research (CIFOR) with ITTO, Bogor, Indonesia.

Sist, P. 2001. 'Why RIL won't work by minimumdiameter cutting alone'. ITTO Newsletter 11.

Sist, P., Sheil, D., Kartawinata, K. and Priyadi, H. 2003a. 'Reduced-impact logging in Indonesian Borneo: some results confirming the need for new silvicultural prescriptions'. Forest Ecology \& Management 179: pp. 41527.

Sist, P., Fimbel, R., Sheil, D., Nasi, R. and Chevallier, M.H. 2003b. 'Towards sustainable management of mixed dipterocarp forests of South-east Asia: moving beyond minimum diameter cutting limits'. Environmental Conservation 30: pp. 364-74.

Styring, A.P. and Ickes, K. 2003. 'Woodpeckers (Picidae) at Pasoh: Foraging ecology, flocking and the impacts of logging on abundance and diversity'. Pasoh: Ecology of a Lowland Rain Forest in Southeast Asia, pp. 547-57.

Styring, A.R. 2002. 'Effects of selective logging on a guild of 13 syntopic woodpecker species in a Malaysian forest reserve'. In Pechacek, P. and d'Oleire-Oltmanns, W. (eds), International Woodpecker Symposium 23-25 March 2001 in Berchtesgarden, Germany. Forschungsbericht 48. Nationalparkverwaltung, Berchtesgaden, Germany, pp. 165-71.

Thiensongrusamee, P., Poonswaad, P. and Hayeemuida, S. 2001. 'Characteristics of Helmeted Hornbill nests in Thailand'. The Third International Hornbill Workshop on the Ecology of Hornbills with Emphasis on Reproduction and Population, 9-18 May 2001, Phuket and Narathiwat, Thailand. Abstracts of paper presentations.

Wadley, R.L., Colfer, C.J.P. and Hood, I.G. 1997. 'Hunting primates and managing forests the case of iban forest farmers in Indonesian Borneo-. Human Ecology 25: pp. 243-71. 
Wilkie, D.S., Shaw, E., Rotberg, F., Morelli, G. and Auzel, P. 2000. 'Roads, development and conservation in the Congo Basin'. Conservation Biology 14: pp. 1614-22.

Wong, A. [undated]. The impact of forestry practices on frog communities in Sabah, Malaysia. PhD Dissertation. Universiti Putra Malaysia, Kota Kinabalu, Malaysia.
Wong, A. 2003. Species diversity and abundance of frogs in different forestry practices in Sabah, Malaysia. In International Conference on Bornean Herpetology 16-17 December 2003. Universiti Malaysia Sabah, Kota Kinabalu, Malaysia.

Zakaria, B.H.M. 1994. Ecological effects of selective logging in lowland dipterocarp forest on avifauna, with special reference to frugivorous birds. Universiti Kebangsaan, Kuala Lumpur, Malaysia. 



\section{CHAPTER 11}

BACK TO THE TREES? DIET AND HEALTH AS INDICATORS OF ADAPTIVE RESPONSES TO ENVIRONMENTAL CHANGE THE CASE OF THE PUNAN TUBU IN THE MALINAU RESEARCH FOREST

Edmond Dounias, Audrey Selzner, Misa Kishi, Iwan Kurniawan and Ronald Siregar 


\section{INTRODUCTION}

It may seem a truism to say that the future of forest ecosystems is inseparable from the future of people living in these forests. But facts on the ground sadly indicate that this evidence is not fully addressed by decision-makers and practitioners of forest management. Accordingly, damage to the health of both the forest and humans should be investigated jointly. Unfortunately, research that is devoted to the consequences of biodiversity loss on human health has long focused on the ecological and global systems and persists in neglecting the more local human sociological and psychological factors that come into play. It becomes more and more urgent that environmentalists, ecologists, anthropologists and medical scientists sit around the same table to investigate the relationships between the many components of forest anthropogenic systems in order to assess the problems that simultaneously compromise the health of forest-based people and the sustainability of their ecosystems. Forest managers and policy-makers urgently need to be oriented towards solutions that combine ecosystem management and health-sector interventions to improve human health and wellbeing while maintaining a healthy ecosystem.

The dramatic situation of the few remaining hunter-gatherer groups who still depend highly on forest resources is emblematic of what is at stake in the context of rapid conversion of forest regions. Recent studies of hunter-gatherers provide models of how humans lived when their lifestyles and their genetic endowment were more clearly compatible. Assessing hunting and gathering ways of life is indeed of vital importance to general human health. The cumulative experience of foraging societies can usefully be viewed as a benchmark for present-day efforts to promote health and prevent disease, even in the world's industrialised countries.

Changes in diet and exposure to emerging diseases are sensitive indicators of the ecological and cultural costs that former hunter-gatherers such as the African Pygmies, the Brazilian Yanomami and the Punan of Borneo, for instance, are actually paying to secure their share of modernity. Such indicators reveal the sociopolitical problems that necessitate concerted and urgent interventions, which respond to both development and conservation interests.
The 'Rousseauistic' image of the noble savage living in harmony in his environment has long persisted, but such romanticism has in turn perversely reinforced the conviction among many practitioners of forest management and conservationists that the forest is unsuitable for humans. The high correlation between the diversity of parasitic and infectious diseases and the distribution of tropical humid forests, have also nourished the persistent belief that forests are inhospitable environments. Such perceptions underestimate the numerous services provided by natural ecosystems in controlling the emergence and spread of infectious diseases. The protective function of biodiversity maintains the balance among predators and prey, and among vectors and parasites in plants, animals, and humans (Chivian, 2001). Governments which seemingly distrust nomadic peoples, whatever the latitude, have leapt at this view to justify decisions to push forest-dwellers outside the forest, purportedly for their own benefit. For decades, promises of better access to education and health services, to markets and job opportunities have been recurrently used by authorities to persuade hunting and gathering societies to embrace a more sedentary lifestyle. But modernisation, often hastened by government incentives, has generally resulted in increased poverty, and the fanciful advantages that development and social change are supposed to bring often turn out to cause social and health disorders. The apparently noble arguments brandished supposedly for the sake of these people often hide a desire for access to the rich biological and mineral resources that are located in the vast territories extensively used by foragers and pastoralists. In poorly inhabited areas, these nomadic people represent an appreciable mass of potential laborers, voters, taxpayers and animists to be proselytised. They also convey an image of savageness that blurs the international credibility of countries aspiring to be viewed as developed and respectable nations. Last but not least, these peoples seldom care about administrative frontiers (Lee and Daly, 1999; Panter-Brick et al., 2001).

The relocation of nomadic people driven by economic, environmental and political factors jeopardises their health conditions by exerting enormous pressure on the environment. Once foragers become sedentary and spend time in larger aggregations, a human reservoir is established that encourages the proliferation 


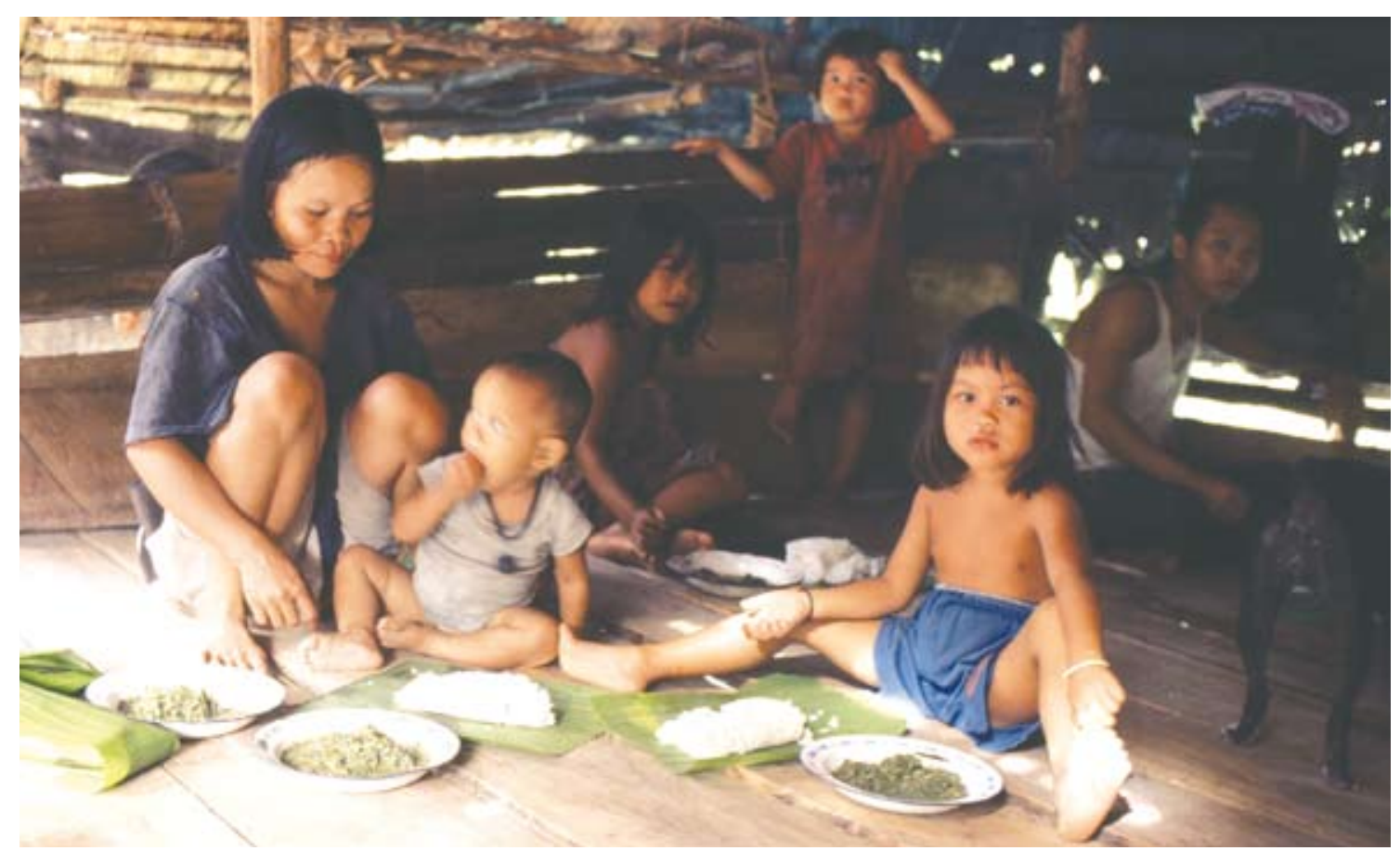

Food consumption in a Punan family. Kuala Rian, June 2003 (Photo by Edmond Dounias)

and continuation of a heavy pathogen load. Environmental changes in local land use after settlement may as well combine with global alterations of climate to disrupt the natural ecosystem, hence producing new favourable habitats to vectors and causing an increased risk of transmission of viral and parasitic infections to humans (Patz et al., 2000).

Objectivity obliges us to recognise that nomadic peoples also have to struggle with their own contradictions: in a world of growing globalisation, they claim their right to continue living in close relation with nature, while at the same time, they are attracted by consumer goods and desire, legitimately, a share of modernity. The renunciation of their nomadic lifestyle is a heavy price to pay to be recognised as full citizens and to benefit from social justice. Unfortunately, choices are generally driven by the immediate and ephemeral, though comprehensible, satisfaction of material wellbeing and much less by long-term moral and patrimonial considerations for the well-being of future generations.

\section{RESEARCH GOALS}

The overarching objective of this chapter is to explore the impact of the conversion to sedentary lifestyle on Punan diet and their related health status. The field study that was carried out in the Malinau Research Forest between 2000 and 2005 aims at comparing the dietary regime and nutritional status of a range of distinct Punan communities. These former hunter-gatherer communities share common socio-cultural characteristics, and all adopted extensive upland rice cultivation almost six decades ago. However, they are distinctively positioned along a gradient of dependency on agricultural products and accessibility of urban facilities. To assess how social change and sedentarisation may affect the diet and the health of these former hunter-gatherers, we undertook a comparative and quantitative study of the changing dependency on forest resources of Punan still living upstream in remote villages, compared to Punan now resettled in the district head city of Malinau. Upstream Punan still seasonally migrate into the forest and depend highly on forest resources for their subsistence. On the other hand, downstream Punan have turned their backs on their former nomadic way of life, and their livelihoods now totally depend 
on local markets, city subsidies and fees from concessionaires. These two populations have the same origins (the Tubu watershed), the same language, the same cultural background and oral traditions, but diverge in their diet, access to health services, relation to the outside world and their perceptions and use of forest resources. We implemented a research programme which combines first-hand data in the fields of economy, demography, spatial and social mobility, seasonality of resources and activities, biomedical survey and a quantitative food consumption survey.

Our research belongs to the field of human ecology and focuses on the interactions between the diet and health status of the Punan. One of its key objectives was to assess the actual contribution of non-timber forest products (NTFPs) to the food and health integrity of the Punan and to determine to what extent differences in access and use of NTFPs can explain the gap in health conditions between remote and peri-urban settlements.

The research consists of analysing Punan food behaviour from several interacting perspectives (Figure 1):

- From a social perspective: relationship between food consumers via food-sharing rules, meal distribution and festive, ritual, ostentatious and curative dishes.
- From a cultural perspective: habits, perceptions and representations concerning medicinal and food resources.

- From an ethno-ecological perspective: knowledge, know-how and access modalities concerning the spatial and seasonal availability of resources.

- From a biological and anthropological perspective: nutritional value of food, and the influence of diet on physiological and epidemiological status.

By comparing the diet and health situations of the Punan of the same group (the Punan Tubu), but in two contrasting social and ecological environments (remote villages compared to recent settlements close to Malinau town and with reference to their recent past as nomadic hunter-gatherers, we question the health consequences of 'development'. In the process of adaptation, every population develops defences against the predators, parasites and pathogens in its environment. But social change such as settling down near a city may not necessarily have positive effects on the well-being of people. Social change may even sometimes destroy or invalidate the defence mechanisms or present new challenges for which there are no defences, thus precipitating an increase in disease and adding to the population's adaptation load. Social change, as generally observed among hunter-gatherers when they shift from nomadic

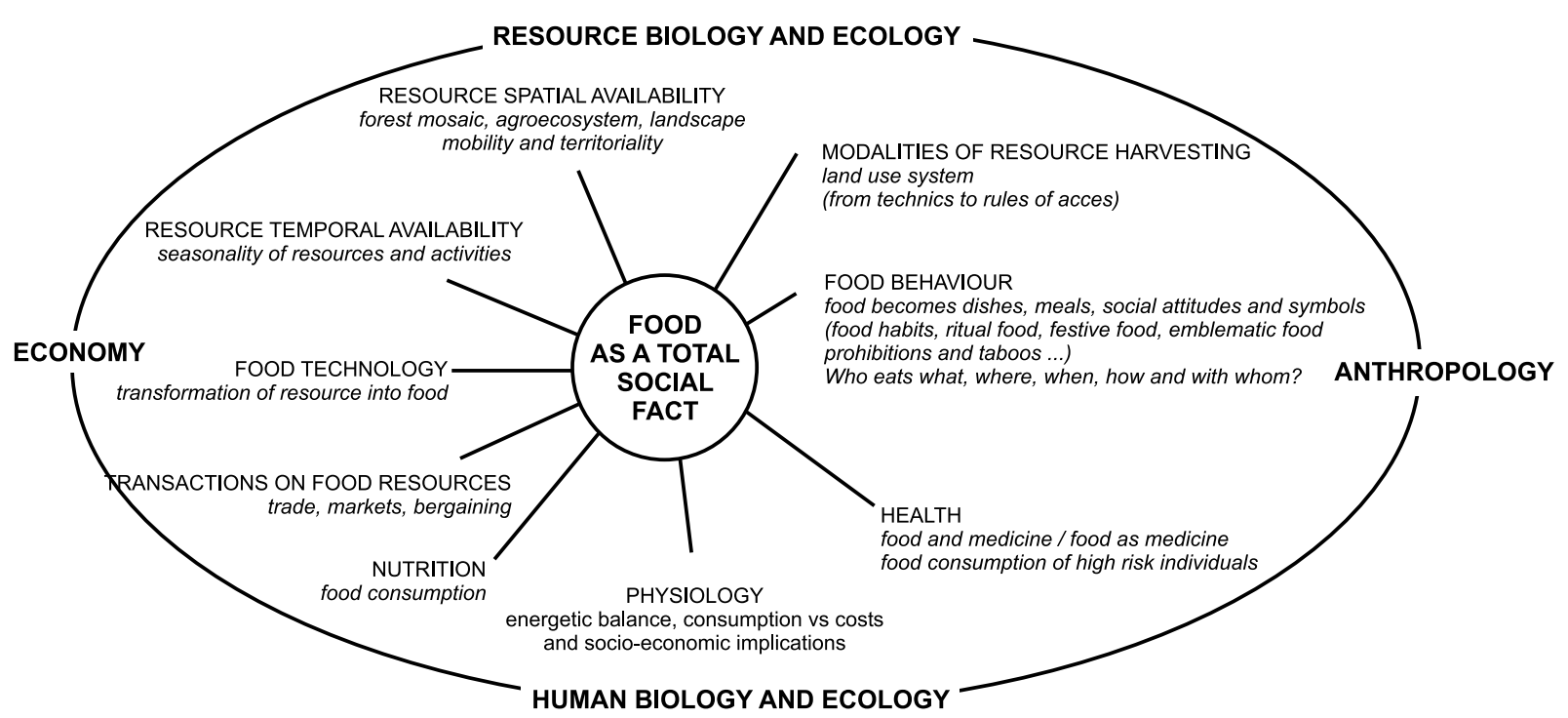

Figure 1. Matrix for the interdisciplinary study of food 
life to settling in permanent villages, may also threaten their nutritional status in various indirect ways.

To achieve the goals of this multidisciplinary research, a series of complementary study protocols was implemented throughout the Tubu watershed (Figure 2).

\section{What's the use of weighing food?}

The study of nutritional status and its implication in food and health security is a focal issue in our approach. It refers to food habits that are oriented by cultural choices and free will. But it is also conditioned by environmental constraints and depends on local strategies of access to resources (wild as well as domesticated). In such a perspective, the comparison of Punan communities from the upper Tubu with semiurbanised Punan from Malinau is of utmost interest.

The goal of the QFCS is to estimate the nutritional value of the dishes for each category of consumers and to identify possible chronic as well as seasonal nutrient deficiencies that may affect health, especially among high-risk groups (children, pregnant women, etc). The reference unit considered is the rumah tangga (the house) that may include several keluarga (households) who may collectively or separately prepare and consume dishes.

\section{How did we proceed?}

A comparative quantitative food consumption survey was carried out in three villages: one suburban settlement near Malinau city (Long Payang), one settlement in middle Tubu (Rian Tubu) and one among the most remote settlements of the Tubu watershed (Long Pada). Food consumption was recorded on a quarterly basis, every three months from May 2003 to July 2004, in order to assess the impact of seasonality on food strategies. We surveyed a total of 43 households distributed over 27 houses.

The survey protocol consisted of weighing systematically during four consecutive days:

- Ingredients before cooking;

- Meals after cooking;

- Food distribution between consumers; and

- Leftovers.
1,214 dishes were measured over the 15-month period of study.

- May-June: 84 house-days, 878 dishes, in 3 villages (Long Pada, Rian Tubu, Long Payang);

- September: 14 house-days, 73 dishes, in 3 villages (Long Pada, Rian Tubu, Long Payang);

- December: 12 house-days, 75 dishes, in 2 villages (Long Pada, Rian Tubu);

- March '04: 17 house-days, 96 dishes, in 3 villages (Long Pada, Rian Tubu, Long Payang);

- July'04: 18 house-days, 92 dishes, in 3 villages (Long Pada, Rian Tubu, Long Payang).

We first started using Yamamoto YB99 baby scales to weigh ingredients and dishes. As precision of these scale is only $20 \mathrm{~g}$, we also used Oliver precise handy scale (maximum weigh $200 \mathrm{~g}$, precision $0.01 \mathrm{~g}$ ) to weigh ingredients used in small quantities such, salt, spices or potassium glutamate. In 2004, we continued with a CB $12 \mathrm{~K} 1 \mathrm{~N}$ Kern industrial scale (capacity $12 \mathrm{~kg}$, readability $1 \mathrm{~g}$ ).

Direct observations provided precious information about the social dimension of food consumption. Who eats with whom? Who receives food from whom? Do households living under the same roof share their meals? If not, why? How many people (and who) eat from the same plate compared to how many (and who) eat individually? What is given to domestic animals?

Complementary to the quantitative and seasonal food consumption survey, we also carried out a longitudinal food survey. The meals of all the households of three villages were systematically noted, but without weighing, and the origins of the ingredients and the identity of the consumers were recorded. Nearly 400 meals were monitored monthly, represented by almost 9,000 monitored meals that are being calibrated by using weight measurements during the quantitative food survey in order to get a more accurate view of diet fluctuation throughout the year. The analyses of the large data set collected during the food consumption survey are still in progress. 


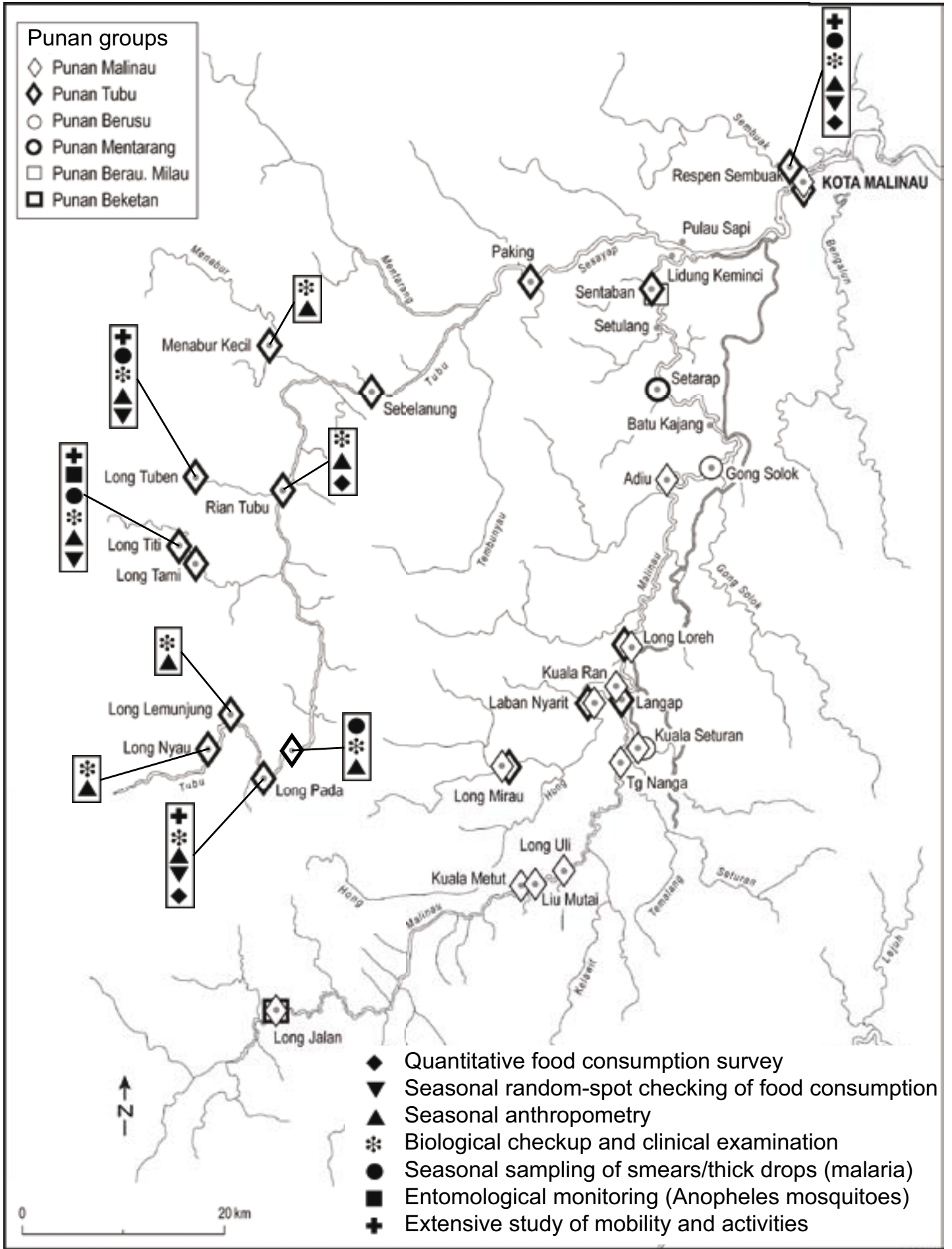

Figure 2. Nutritional ecology of the Punan Tubu. Location of sites and study types 


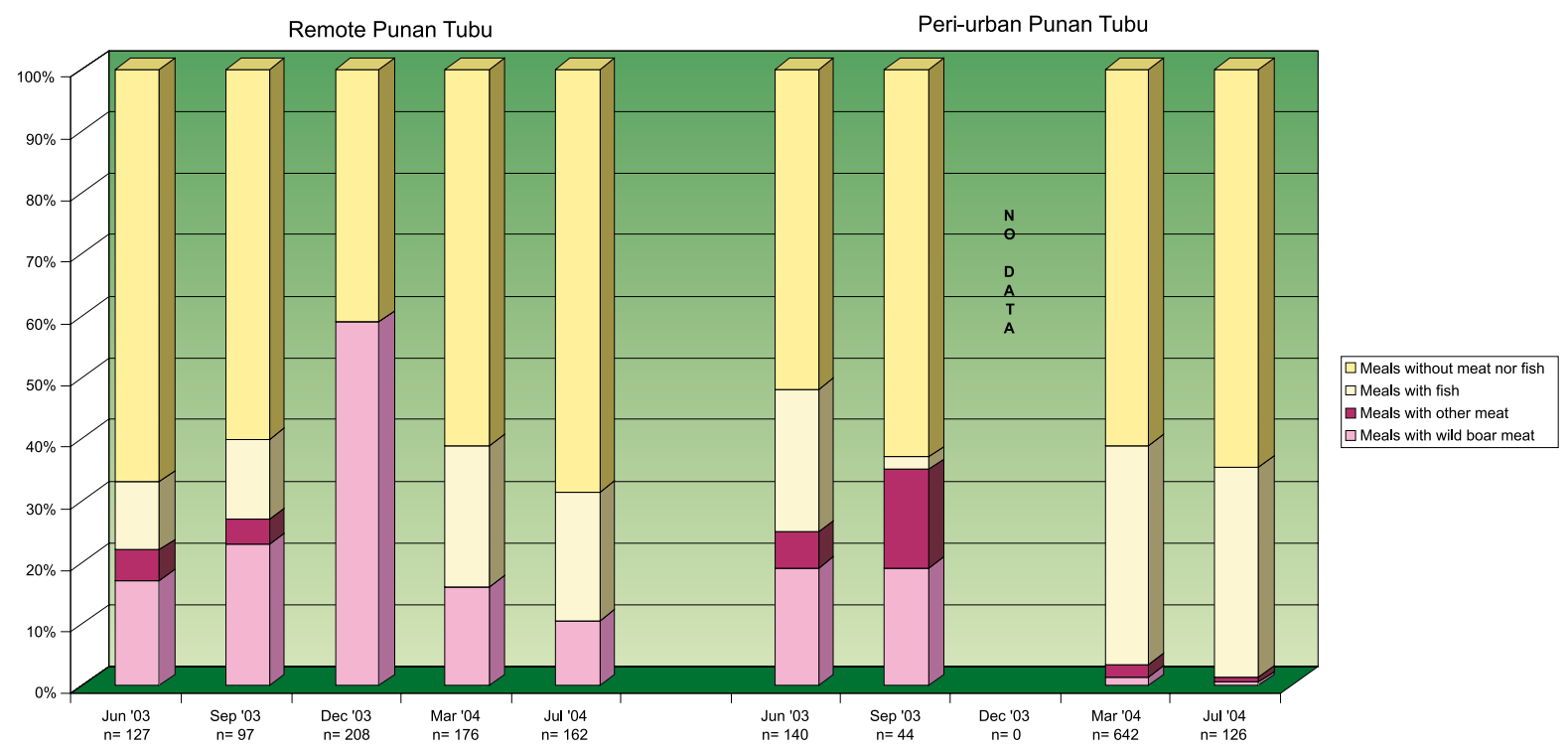

Figure 3. Seasonal use of the main food categories for the three distinct locations

\section{RESULTS}

Figure 3 presents the proportions of major categories of food (meat, fish, vegetables and starchy staple food) used in Punan meals. This figure is composed of three distinct graphs that show the seasonal fluctuations (June' 03, Sept '03, Dec '03 and March '04) in using these categories of food within the three compared locations (peri-urban, middle Tubu, remote Tubu). These graphs show:

- Significant differences between locations during the same season. For instance, if we consider March '04, meat was rare in the diet of peri-urban Punan whereas it was abundant in remote Tubu. By contrast, vegetable consumption was much higher near cities and less frequent in remote villages;

- Significant differences between middle Tubu and remote Tubu. The differences we observed cannot always be explained by distinct accessibility to cities between these two settlements. They also express different strategies among remote villages, mainly based on time allocated to agricultural versus non-agricultural activities;

- Significant fluctuations of diet according to season.

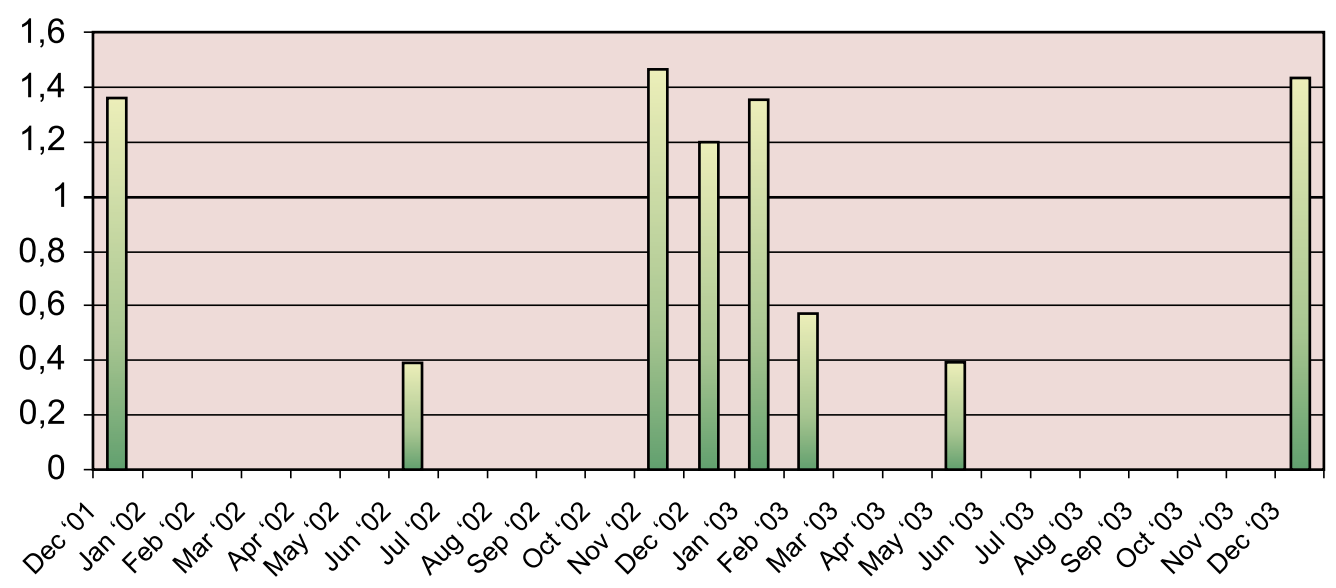

Figure 4. Seasonal fluctuation of the daily rate of wild boar captured in Long Pada village 


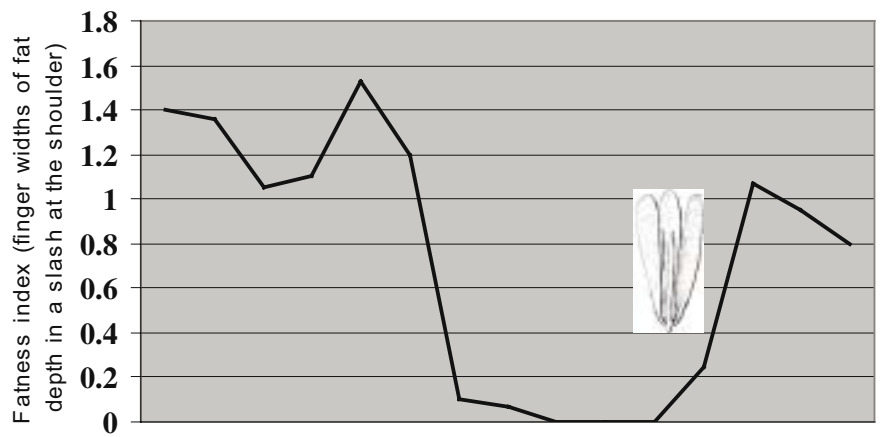

$\begin{array}{lllllllllllllll}\text { A } & \text { M } & \mathbf{J n} & \mathbf{J t} & \mathbf{A} & \mathbf{S} & \mathbf{O} & \mathbf{N} & \mathbf{D} & \mathbf{J} & \mathbf{F} & \mathbf{M} & \mathbf{A} & \mathbf{M} & \mathbf{J n}\end{array}$ 1984-1985

Figure 5. Seasonal fluctuation of wild boar meat

The sources of animal protein are mainly meat (eggs are eaten only by peri-urban residents) and, to a lesser extent, fish. The sources of protein are much more diversified in remote areas, and protein is consumed in these areas in greater quantities. Meat and fish consumption are facilitated by persisting social regulations such as mutual aid and food sharing, which impose rules of systematic redistribution of bushmeat and massive fish catches among the whole community. Downstream, where rules of mutual aid are in constant decline, opportunities to consume protein-rich food are more erratic and the food is more costly.

As it is commonly known, the Punan have a strong preference for wild boar meat (Dounias, in press). But since wild boar is a seasonal resource, the contribution of other sources of meat to the diet also fluctuates accordingly. Wild boar meat is more difficult to obtain near the city (and this fatty meat rapidly deteriorates after a couple of weeks, so the possibilities for storage and delayed cooking are limited). On the other hand, the proximity to markets offers greater opportunities to find other meat (from Sambar deer, monkeys, chicken), thus explaining the higher meat diversity in peri-urban villages.
Wild boar is a very seasonal prey as this mammal migrates following patterns that are not yet well understood but are thought be highly dependent on the erratic mast fruiting of dipterocarp trees (Figure 4). As shown in Table 1, the type of wild boars captured varies also according to seasons (mainly gravid or brood females in December, mainly adult males five months later). To conclude, the contribution of wild boar meat to the diet fluctuates both in quantity and quality. The nutritional value of meat (illustrated by Figure 5 by the fluctuating fat content contained in wild boar meat) also changes according to seasons. For instance, the organoleptic characteristics of the meat are affected when the females are gravid, or during the season of reproduction when high concentrations of uric acid during mating periods compromise the palatability of male prey meat.

Carbohydrates, which provide energy and are the staples of the diet, are mainly provided by cultivated tuber and cereal crops (Table 2). Six types of food crops are grown in the remote areas, twice the number in the other areas. Depending on the season, rice is the staple food in $80 \%$ to $100 \%$ of the meals (percentages provided hereafter accordingly correspond to the percentage of meals containing the food). After sedentarisation, rice rapidly replaces sago as the major staple food. However, the Punan are not true farmers, and remote villages are far from being self-sufficient in rice. However, opportunities to bring rice back from the city are more frequent in middle Tubu. During periods of rice shortage, the remote Punan depend heavily on starchy tubers. Again, different food habits emerge between middle and remote Tubu villages. While middle Tubu villagers prefer to eat cassava flour, those living more upriver predominantly eat cassava tubers.

Sago starch used to be the staple food for the Punan Tubu before they became sedentarised. It

Table 1. Seasonal fluctuation in the type of captured wild boars

\begin{tabular}{lcc}
\hline & December $\mathbf{2 0 0 1}$ & May-June 2002 \\
\hline Hunting expeditions per day & 1.4 & 0.9 \\
\hline Unsuccessful hunting expeditions & $22 \%$ & $68 \%$ \\
\hline Contribution of wild boars to total preys & $83 \%$ & $47 \%$ \\
\hline Most frequently captured & Gravid/brood females (53\%) & Males (63\%) \\
\hline
\end{tabular}


Table 2. Seasonal fluctuation of consumption of the main food categories by the Punan Tubu (g/capita/ day) (weighed meals: Jun 03: $n=878$; Sep: 03: $n=73$; Dec 03: $n=75$; March 04: $n=96$ )

\begin{tabular}{|c|c|c|c|}
\hline & Month & Remote Punan Tubu & Peri-urban Punan Tubu \\
\hline \multirow{4}{*}{ Meat and eggs } & Jun '03 & 130.4 & 72.9 \\
\hline & Sep '03 & 60.9 & 65.1 \\
\hline & Dec '03 & 191.3 & No data \\
\hline & Mar '04 & 31.8 & 14.8 \\
\hline \multirow{4}{*}{ Fish and shellfish } & Jun '03 & 43.9 & 42.2 \\
\hline & Sep '03 & 34.9 & 4.9 \\
\hline & Dec ’03 & 0.0 & No data \\
\hline & Mar '04 & 58.9 & 63.9 \\
\hline \multirow{4}{*}{ Starchy staples } & Jun '03 & 889.1 & 1000.2 \\
\hline & Sep '03 & 545.9 & 1033.4 \\
\hline & Dec '03 & 298.7 & No data \\
\hline & Mar '04 & 581.7 & 886.5 \\
\hline \multirow{4}{*}{ Vegetables } & Jun '03 & 91.8 & 87.5 \\
\hline & Sep '03 & 49.1 & 74.8 \\
\hline & Dec '03 & 33.2 & No data \\
\hline & Mar '04 & 62.4 & 203.1 \\
\hline \multirow{4}{*}{ Oils and fats } & Jun '03 & 2.5 & 9.5 \\
\hline & Sep '03 & 0.1 & 4.3 \\
\hline & Dec '03 & 0.0 & No data \\
\hline & Mar '04 & 0.7 & 11.9 \\
\hline
\end{tabular}

remains important only for the remote villagers $(12 \%$ of meals) and only during seasonal migration into the forest for hunting and NTFP gathering. Sago has totally disappeared from the diet of peri-urban Punan. The extraction of sago starch is a long and complicated process, which affects the nutrient content of the resource. After cooking, the energy value and caloric return of sago starch is very high. Unfortunately repeated filtration of starches wash out the few vitamins contained within it. Manufactured noodles, an exotic and rare delicacy for the remote Punan Tubu, appear in $5 \%$ of the meals prepared by their peri-urban relatives.

The peri-urban Punan Tubu eat twice as many vegetables as the remote Punan Tubu. The gap is even more pronounced when meat is seasonally difficult to obtain downriver and the dietary regime of the peri-urban residents becomes almost vegetarian. Near the city, the Punan
Tubu, who practise swidden-fallow agriculture, cultivate 45 species of vegetables, spices and seasoning plants, three times as many as are cultivated by the remote Punan Tubu, and they consume them much more frequently. Upriver, fern crosiers and cassava leaves represent $85 \%$ of the total amount of vegetables consumed, compared with only $47 \%$ near the city.

The remote Punan Tubu consume oil and fat in more moderate quantities. The fat they use for cooking is mainly obtained from wild boar and is progressively replaced further downstream by manufactured palm oil, a monosaturated fatty acid that is poorly digested but is fairly cheap to produce (without taking into account the damaging ecological impact of oil-palm plantations). Palm oil is extensively used locally for cooking and is also found in snacks and many other manufactured foods. 
Table 3. Proportion of shared plates decreases with proximity of the city (\% of meals)

\begin{tabular}{lcccc}
\hline & Jun '03 & Sep '03 & Dec '03 & Mar '04 \\
\hline \multicolumn{1}{c}{$\mathrm{n}$} & 4042 & 255 & 374 & 486 \\
\hline Peri-urban Punan Tubu & 10 & no data & no data & 17.4 \\
\hline Middle Tubu & 20 & 19.2 & 18.7 & 27.8 \\
\hline Remote Tubu & 25 & 40 & 33.1 & 28.9 \\
\hline
\end{tabular}

Table 4. Increasing proportion of snack consumption with proximity of the city (\% of meals)

\begin{tabular}{lcccc}
\hline & Jun '03 & Sep '03 & Dec '03 & Mar '04 \\
\hline Peri-urban Punan Tubu & 21.5 & 10.4 & no data & 0.1 \\
\hline Middle Tubu & 1.7 & 2.8 & 1.5 & 0.4 \\
\hline Remote Tubu & 0.8 & 1.5 & 1.3 & 1.2 \\
\hline
\end{tabular}

\section{Changes in food habits: food sharing and consumption of snacks}

Food habits are also important to assess. For instance, they may inform us on mother/child relations and on how mothers manage weaning, which is a critical nutritional breakthrough during childhood. Collective activities and mutual aid for house building, swidden clearing, planting or harvesting, are social and festive occasions marked by food sharing. Food sharing is commonly practised by collectivist societies as an efficient adaptive response to temporary food scarcity (Dounias and Colfer, in press). The frequency of food sharing is thus a relevant indicator of persisting or degrading collectivist practices.

In Table 3, the frequency of shared plates is compared between remote and peri-urban settlements. Whatever the season, the proportion of shared plates is lower in peri-urban settlements, thus expressing a severe regression of mutual aid near the city. We observed the same tendency for gifts of food before cooking, like the distribution of bush meat. 'Nowadays if you want to eat you have to pay' is a popular lament in periurban resettlements. Another illustration is the decreasing proportion of food resources that are obtained as gifts or through exchange: $18.1 \%$ compared to $5.1 \%$ among the remote and periurban Punan Tubu, respectively. By contrast, the proportion of purchased ingredients, another symptom of more individualistic economic strategies, increases with access to markets: the proportion is $26.2 \%$ for the remote Punan Tubu compared to $57.2 \%$ for the peri-urban Punan Tubu.

Another remarkable aspect of food consumption shown in Table 4 is the poor proportion of snacks compared to other forest dwellers. Our data also reveal significant differences between remote and peri-urban villages and more frequent snacks among peri-urban villagers who can buy cakes and 'fast food' from mobile vendors. The types of snacks differ according to location: hot drinks and fruits in remote villages compared to cakes and ice creams, 'fast food' and fatty and salty appetizers near the city.

\section{Comparative biomedical survey among the Punan villages of the Tubu watershed and Respen Tubu}

The biomedical survey included six components:

- Regular update of the Punan census and extensive study of child mortality;

- Seasonal anthropometric measurements;

- Blood sampling and analysis;

- Urine sampling and analysis.

- Stool sampling and analysis; and

- Clinical examination and provision of medical treatment. 
Table 5. Pregnancies and child births during lifetime (data for post-menopausal women only)

\begin{tabular}{lcc}
\hline & $\begin{array}{c}\text { Remote Punan } \\
\text { Tubu }(\mathbf{n}=\mathbf{2 0})\end{array}$ & $\begin{array}{c}\text { Peri-urban Punan } \\
\text { Tubu }(\mathbf{n}=\mathbf{2 7})\end{array}$ \\
\hline Pregnancies during lifetime & 8.8 & 7.8 \\
\hline Miscarriage (\% of pregnancies) & 20.7 & 25.0 \\
\hline Still alive (\% of births) & 48.4 & 67.5 \\
\hline Dead before weaning (\% of death) & 56.7 & 53.2 \\
\hline Dead between weaning and 5 year old (\% of death) & 14.4 & 31.2 \\
\hline Dead after 5 years old (\% of death) & 28.9 & 15.8 \\
\hline
\end{tabular}

\section{Regular update of the Punan census and study of child mortality}

A nominal census of the members of every household of the Tubu watershed was regularly and seasonally updated by registering births, deaths and in-coming visitors and by correcting mistakes concerning name, gender and age, as well as any change in location. Since 2002, the census that we have been undertaking and regularly updating among the Punan of East Kalimantan has revealed a high proportion of children who die before reaching the age of five. The data also revealed a significant difference between the peri-urban Punan of Respen Tubu (ratio of child death is 6\%) and the remote Punan of the Tubu watershed (first estimation of child death ratio was $35 \%$ ). In order to clarify the possible causes of child death, especially during the first two years, we decided to undertake a study focusing on female fecundity and child care among the Punan Tubu. The study was composed of two complementary protocols:

- Semi-quantitative and factual questionnaires submitted to every woman who had already given birth at least once by the time of the study;

- Qualitative in-depth interviews to try to catch women's perceptions on the major causes of child mortality.

The questionnaire (195 respondents aged 16 to 72 years old, 81 near city, 114 in remote villages) was composed of four modules regarding

- The woman's background (literacy, marital status);

- Pregnancy, labour/delivery and post-labour (with record of all births);

- Knowledge and practice of contraception; and

- Experience of breastfeeding.
The average age of the respondents was 35.2 years old. A preliminary overview of the data reveals that the average number of pregnancies experienced by remote Punan women during their lifetime is 8.8 in remote locations vs. 7.8 among peri-urbans. Miscarriage affects $20.7 \%$ of pregnancies in remote locations compared to $25 \%$ near the city. Among children who were born, only $48.4 \%$ are still alive in remote areas compared to $67.5 \%$ near the city. Table 5 shows that the majority of children die before weaning, particularly in remote areas, and a relatively high proportion of children die after the age of five. As figures refer to post-menopausal women (more than 50 years old) who similarly have grown up in the forest, the comparison reveals a beneficial effect of city proximity on the lifespan of children, which results in a significant decrease in the number of pregnancies (this age bracket is little concerned with recently introduced contraceptive methods). Through vaccination facilities, city proximity increases children immunisation against infectious diseases and epidemics that continue heavily killing upriver beyond the age of five. But Punan women rarely consult doctors during pregnancy, whatever the location, and miscarriage remains high among both communities and is even higher among the peri-urban. This could be a consequence of change in dietary regime caused by resettlement near the city, but data are lacking to confirm this assumption.

The goal of the qualitative interviews was to try to obtain a clearer idea of the ways in which Punan women respond, practically and philosophically, to the high rate of mortality affecting their children. Recurrent questions concerned women's experience regarding child health (causes of death and disease, difficulties regarding breastfeeding and weaning), women's 
Table 6. People measured seasonally

\begin{tabular}{|c|c|c|c|c|c|c|}
\hline & & & $\begin{array}{c}\text { Male } \\
\text { children }\end{array}$ & $\begin{array}{l}\text { Female } \\
\text { children }\end{array}$ & $\begin{array}{c}\text { Male } \\
\text { adults }\end{array}$ & $\begin{array}{c}\text { Female } \\
\text { adults }\end{array}$ \\
\hline \multirow{2}{*}{ May - June '03 } & \multirow{2}{*}{$n=524$} & Remote Tubu & 94 & 74 & 96 & 122 \\
\hline & & Peri-urban & 21 & 21 & 44 & 52 \\
\hline \multirow{2}{*}{ September '03 } & \multirow{2}{*}{$n=349$} & Remote Tubu & 88 & 72 & 50 & 84 \\
\hline & & Peri-urban & 8 & 15 & 13 & 19 \\
\hline \multirow{2}{*}{ December '03 } & \multirow{2}{*}{$n=451$} & Remote Tubu & 98 & 99 & 86 & 99 \\
\hline & & Peri-urban & 20 & 20 & 16 & 23 \\
\hline \multirow{2}{*}{ March '04 } & \multirow{2}{*}{$n=422$} & Remote Tubu & 95 & 88 & 73 & 105 \\
\hline & & Peri-urban & 11 & 16 & 16 & 18 \\
\hline \multirow{2}{*}{ July '04 } & \multirow{2}{*}{$n=422$} & Remote Tubu & 110 & 77 & 92 & 96 \\
\hline & & Peri-urban & 8 & 13 & 11 & 15 \\
\hline
\end{tabular}

Table 7. Synthesis of BMI results

\begin{tabular}{|c|c|c|c|c|c|}
\hline & & \multicolumn{2}{|c|}{ Remote Punan Tubu } & \multicolumn{2}{|c|}{ Peri-urban Punan Tubu } \\
\hline & & Male & Female & Male & Female \\
\hline \multirow[t]{6}{*}{ June '03 } & $n$ & 96 & 126 & 40 & 46 \\
\hline & Severe underweight & $0.0 \%$ & $5.6 \%$ & $7.5 \%$ & $6.5 \%$ \\
\hline & Underweight & $4.2 \%$ & $27.8 \%$ & $22.5 \%$ & $32.6 \%$ \\
\hline & Normal & $94.8 \%$ & $65.1 \%$ & $67.5 \%$ & $54.3 \%$ \\
\hline & Overweight & $1.0 \%$ & $1.6 \%$ & $2.5 \%$ & $4.3 \%$ \\
\hline & Severe overweight & $0.0 \%$ & $0.0 \%$ & $0.0 \%$ & $2.2 \%$ \\
\hline \multirow[t]{6}{*}{ September '03 } & $n$ & 47 & 78 & 14 & 18 \\
\hline & Severe underweight & $2.1 \%$ & $2.6 \%$ & $0.0 \%$ & $0.0 \%$ \\
\hline & Underweight & $25.5 \%$ & $25.6 \%$ & $35.7 \%$ & $50.0 \%$ \\
\hline & Normal & $72.3 \%$ & $71.8 \%$ & $57.1 \%$ & $44.4 \%$ \\
\hline & Overweight & $0.0 \%$ & $0.0 \%$ & $7.1 \%$ & $5.6 \%$ \\
\hline & Severe overweight & $0.0 \%$ & $0.0 \%$ & $0.0 \%$ & $0.0 \%$ \\
\hline \multirow[t]{6}{*}{ December '03 } & $n$ & 74 & 95 & 21 & 18 \\
\hline & Severe underweight & $1.4 \%$ & $5.3 \%$ & $9.5 \%$ & $5.6 \%$ \\
\hline & Underweight & $8.1 \%$ & $22.1 \%$ & $23.8 \%$ & $38.9 \%$ \\
\hline & Normal & $90.5 \%$ & $70.5 \%$ & $66.7 \%$ & $44.4 \%$ \\
\hline & Overweight & $0.0 \%$ & $2.1 \%$ & $0.0 \%$ & $11.1 \%$ \\
\hline & Severe overweight & $0.0 \%$ & $0.0 \%$ & $0.0 \%$ & $0.0 \%$ \\
\hline \multirow[t]{6}{*}{ March '04 } & $\mathrm{n}$ & 61 & 97 & 21 & 16 \\
\hline & Severe underweight & $0.0 \%$ & $2.1 \%$ & $14.3 \%$ & $6.3 \%$ \\
\hline & Underweight & $9.8 \%$ & $26.8 \%$ & $19.0 \%$ & $48.3 \%$ \\
\hline & Normal & $90.2 \%$ & $69.1 \%$ & $66.7 \%$ & $25.0 \%$ \\
\hline & Overweight & $0.0 \%$ & $2.1 \%$ & $0.0 \%$ & $18.8 \%$ \\
\hline & Severe overweight & $0.0 \%$ & $0.0 \%$ & $0.0 \%$ & $6.3 \%$ \\
\hline
\end{tabular}




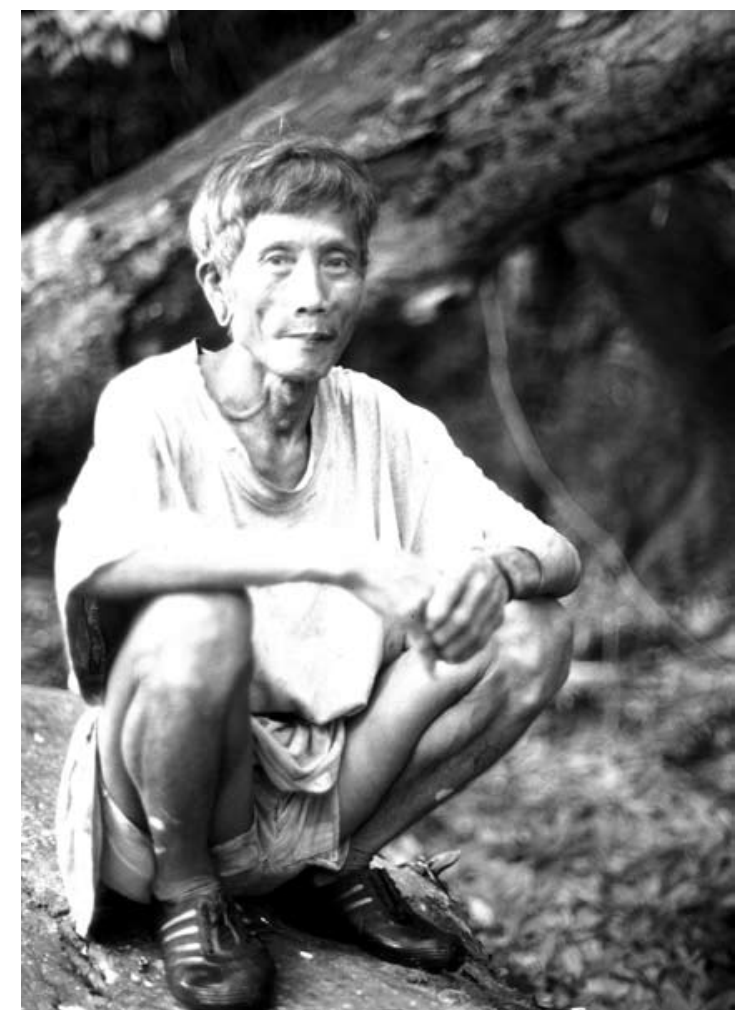

Ilah Baya, one of the most renowned Punan traditional healers of the Tubu watershed. Improved conciliation between traditional healing and modern medicine is a major challenge for the future of forest dwellers. Long Pada, June 2002 (Photo by Edmond Dounias)

general and reproductive health, perceptions regarding handicap, sterility and lifestyle changes (past nomadic lifestyle compared to current sedentarised and farming lifestyle). Additional questions were added depending on information emerging from the questionnaire (all women interviewed had previously answered the questionnaire). Fifteen women were interviewed and interviews were recorded, analysed and coded (an average of 120 minutes for each interviewee).

\section{Seasonal anthropometric measurements}

As a complement to the food survey, we made biometric measurements of nearly 400 people every three months (Table 6). Measurements such as weight and size allowed for the calculation of Body Mass Index (BMI) which is a commonly used index to assess nutritional status. We also made six different skinfold and perimeter measurements that are, for instance, necessary to follow up child growth and calculate body fat, which is another standard indicator. In total, eight measurements were made on adults (above 15 years old) in order to follow the seasonal variation of body fat in relation to diet (food richness in fat is mainly provided by wild boar meat, health status and activities). Five measurements were made of children (2-15 years old) in order to estimate (i) the speed of growth on a semi-longitudinal basis, (ii) the instantaneous nutritional state, and (iii) body morphology in relation to physiological performance. Skinfold measurements were performed using a Harpenden caliper and following the method recommended by Durnin and Womersley. The anthropometric database is comprised of 828 individual files, and nearly 14,000 measurements were performed: weight (children, adults); stature upright (children, adults); stature seated (children only); brachial perimeter (children, adults); waist perimeter (adults only); bicipital skinfold (children, adults); tricipital skinfold (adults only); suprailiac skinfold (adults only); subscapular skinfold (adults only).

The Body Mass Index values of adult respondents are organised according to five categories (Table 7): severe underweight, underweight, normal, overweight, obesity. This table shows that a fraction of the women population is chronically underweight, whatever the location. Most of these women are relatively elderly widows who are highly dependent on gifts from other villagers for their subsistence as they generally cultivate only small cassava gardens and receive meat from others. Heads of households have a sense of self-sacrifice, and as far as food sharing is concerned they often give priority to the younger members of the family. Such behaviour seems deeply anchored in tradition, thus explaining that we observe no difference between remote and peri-urban locations.

On the opposite side, the results also show that being overweight and obesity remain rare among the Punan and as yet affects only peri-urban women. Emerging obesity in Respen Sembuak in this category may be due to new social expressions of prosperity among 'rich' families who are influenced by the wealthy Chinese shop owners and traders. 


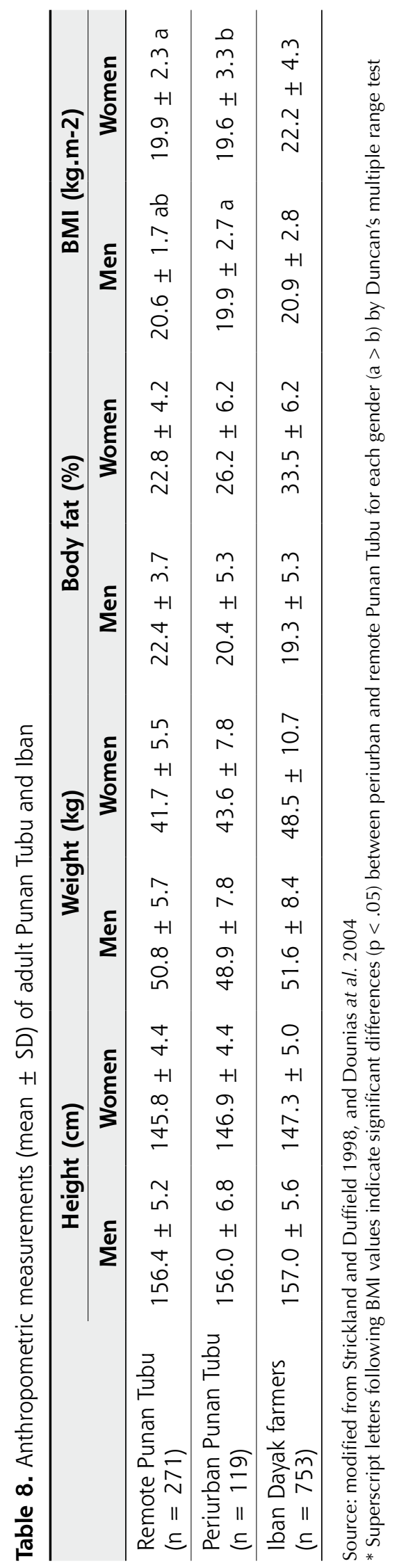




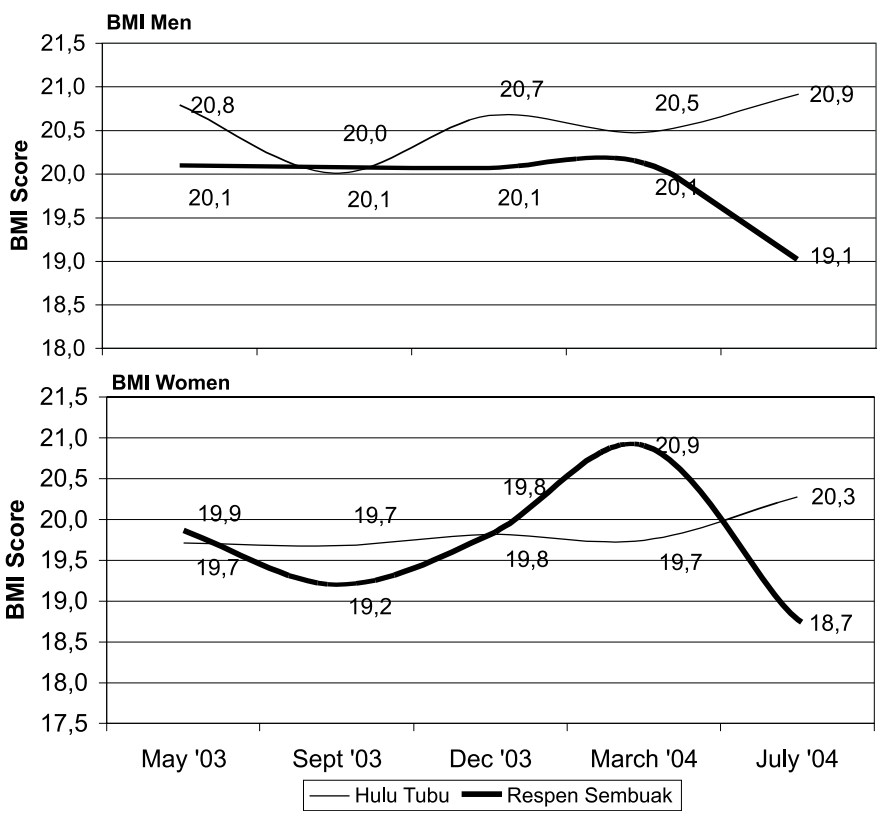

Figure 6. Seasonal fluctuation of BMI among adult Punan

Whatever the season, the average BMI values of both men and women in both remote and periurban Punan Tubu settlements remained above the 18.5 threshold value below which chronic energy deficiency could be suspected (Table 8). The remote Punan have a significantly higher BMI than the Punan Tubu, who have become farmers near the city. Nevertheless, the two Punan Tubu groups have lower BMI values than the Iban of Sarawak, a group of Dayak farmers of Borneo whose BMI values were recently measured. The BMI values of the Iban farmers are closer to the values that are theoretically considered as optimal for adults (22.7 for men and 22.4 for women). Comparisons of BMI between recently sedentarised hunter-gatherers and their immediate farming neighbours in other places of the world have revealed a similar difference (Dounias and Froment, 2006). The difference in fitness between former hunter-gatherers and farming groups should thus not be attributed to the farming lifestyle alone, but should rather be considered a consequence of the disruptive change in lifestyle from nomadic to sedentary.

Body fat percentage, another frequently used nutritional index, is the fraction of the total body mass composed of adipose tissue. It is often used to monitor progress during a diet or as a measure of physical fitness. Values obtained for adults in both remote and peri-urban Punan Tubu settlements are within the range of those of extremely fit or athletic people. Interestingly, the trends differ with regard to gender: peri-urban women have a much higher score than those in remote communities. By contrast, peri-urban men have a lower score than those in remote communities. This may be due to the custom of assigning the 'lion's share' of the rind of wild boar meat to hunters. Values from the Iban farmers indicate that the gap in fitness between men and women increases with sedentary lifestyle. According to European standards, Iban women can be considered as 'stout'.

Signs of being overweight, as opposed to obese, which is extremely rare among rural southeast Asians, clearly occur as a consequence of sedentarisation and related changes in diet. Depending on the season, $4.3 \%$ to $18.8 \%$ of peri-urban Punan Tubu women, but only $1.6 \%$ to $2.1 \%$ of women in remote villages, are overweight.

So far we still need to analyse these results with regard to the contrasted calendar of activities and the distinct gender division of labour between the two types of settlements, but also in the light of different exposure to disease. Indeed, in July 2004 contagious disease affected the city dwellers and not the remote villagers. As a consequence of this temporary sickness, the BMI dropped significantly. We should mention that during the time when the Punan were nomadic hunter-gatherers, they were rarely exposed to contagious diseases, and during epidemics they practised an efficient barter behaviour that prevented them from having any direct physical contact with potentially contaminated traders.

\section{Blood sampling and analysis}

Around 430 people aged four years old and above voluntarily gave blood (310 in upper and middle Tubu, 120 in Respen Tubu). Venous blood was taken away in two tubes of $3.5 \mathrm{ml}$ each using a Vacutainer ${ }^{\circledR}$ blood sampling system. One dry tube (spontaneous coagulation) served for the extraction of serum (conserved in $1.5 \mathrm{ml}$ micro-tubes) and residue was destroyed. The second tube contains EDTA (anti-coagulant) and served for the preparation of smears and thick drops on slides as well as for the extraction of plasma (also conserved in $1.5 \mathrm{ml}$ micro-tubes). Deposit in the EDTA tube (buffy coat) was also preserved. 


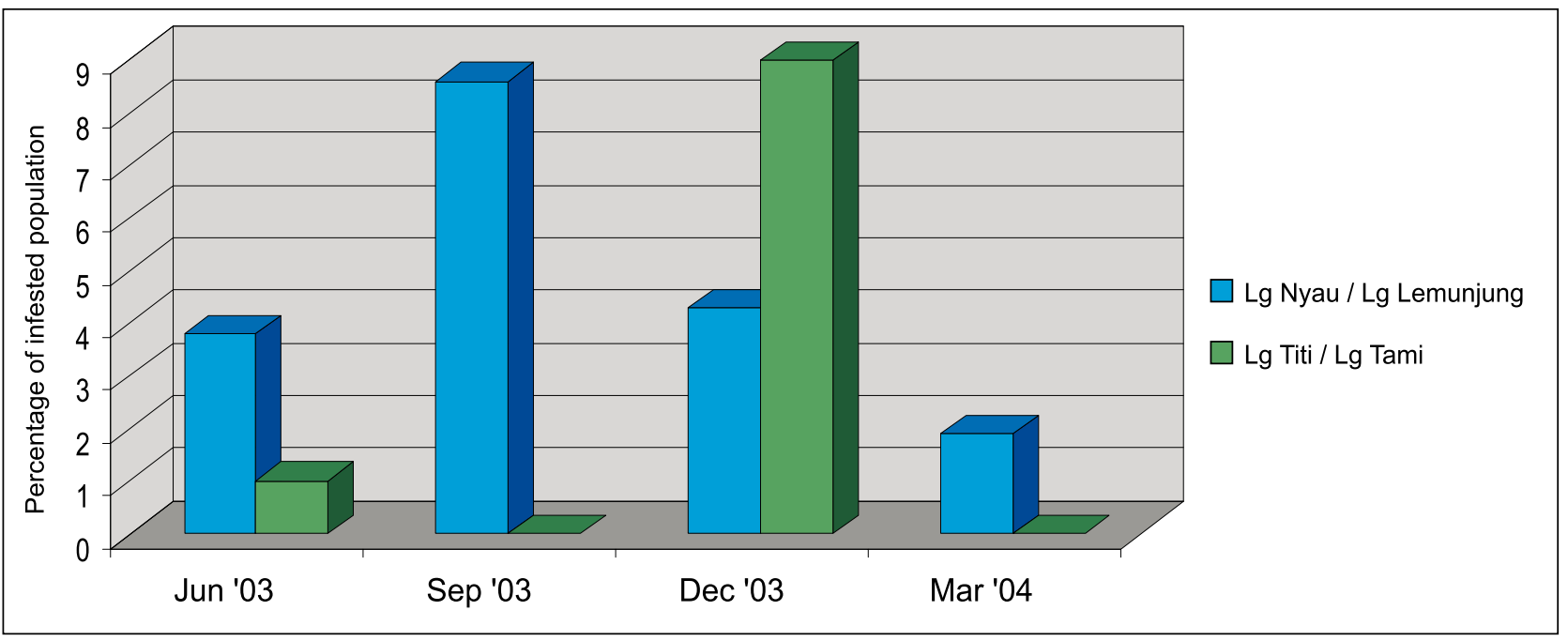

Figure 7. Compared malaria prevalence in two contrasted areas of the Tubu watershed

Analyses are currently being performed by the following French laboratories:

- The research Unit 034 of IRD - Emerging Viral Diseases and Information Systems. This research team is mainly interested in the transmission of emerging viral diseases from hunted mammals to human consumers of bush meat;

- The research Unit 'Oncogenic Virus Epidemiology and Pathophysiology' at the Pasteur Institute in Paris. This Foundation has developed a worldwide network of laboratories which carries out routine analyses for the search of the most common tropical diseases.

The goal of such analyses is to search for potential infectious and parasitic serologies (dengue fever, filariasis, hepatitis, sexually transmissible diseases) and genetic markers (electrophoresis of serum proteins).

We also took away a few drops of capillary blood from fingers on a seasonal basis. We used a lancing device which is totally painless to take away nearly 850 samples over a 15-month period of observation. Blood samples were taken in two groups of villages: Long Nyau and Long Ranau in upper Tubu, versus Long Titi and Long Tami along the Kalun River. Slides of smears and thick drops were coloured with GIEMSA and fixed in ethanol immediately after removal. The slides were analysed by a private laboratory in Jakarta.
The prevalence of malarial pathogens between the two groups during successive seasons is compared in Figure 7 . The prevalence differs significantly between the two locations both in intensity and in frequency. The rates we obtained are consistent with the average reported throughout Kalimantan. The prevalence of malaria is much less important than in transmigration villages of West Kalimantan. Seasonal fluctuations are more intense along the Kalun. In 2002, 26 children died of malaria in these villages within a five-month period. We are probably confronted with an epidemic scenario, which is rarely reported in the literature.

The high probability for such an epidemic scenario requires a combination of several factors:

- Firstly, low immunity to malaria by the group studied. The nomadic Punan were rarely exposed to malaria until they finally settled down in permanent villages;

- Secondly, it is necessary to be exposed occasionally to areas where malaria is endemic. This happens when some families migrate to Sarawak for a few months or even years, and possibly bring back malaria with them from agro-industrial camps in which men have been recruited temporarily. 


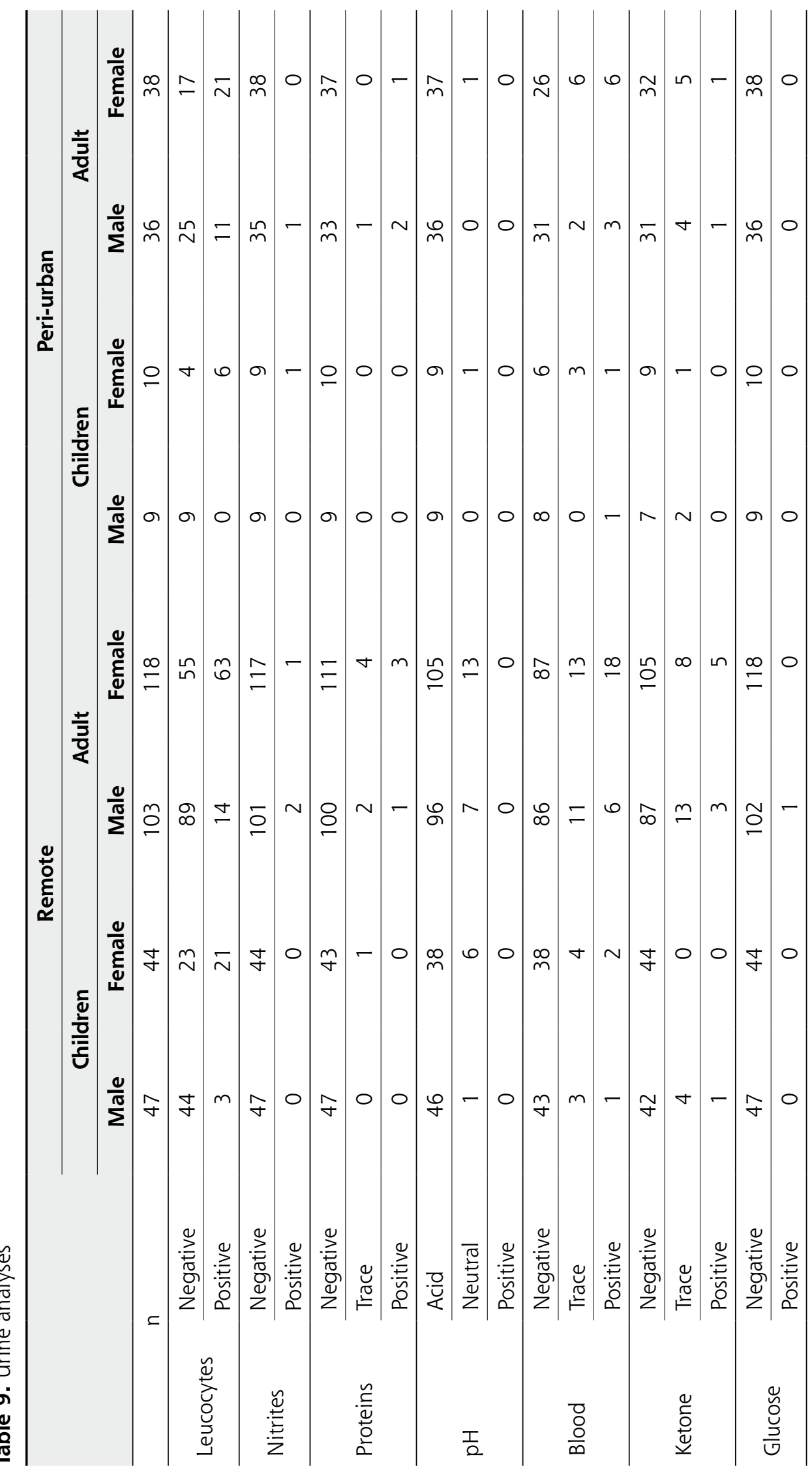




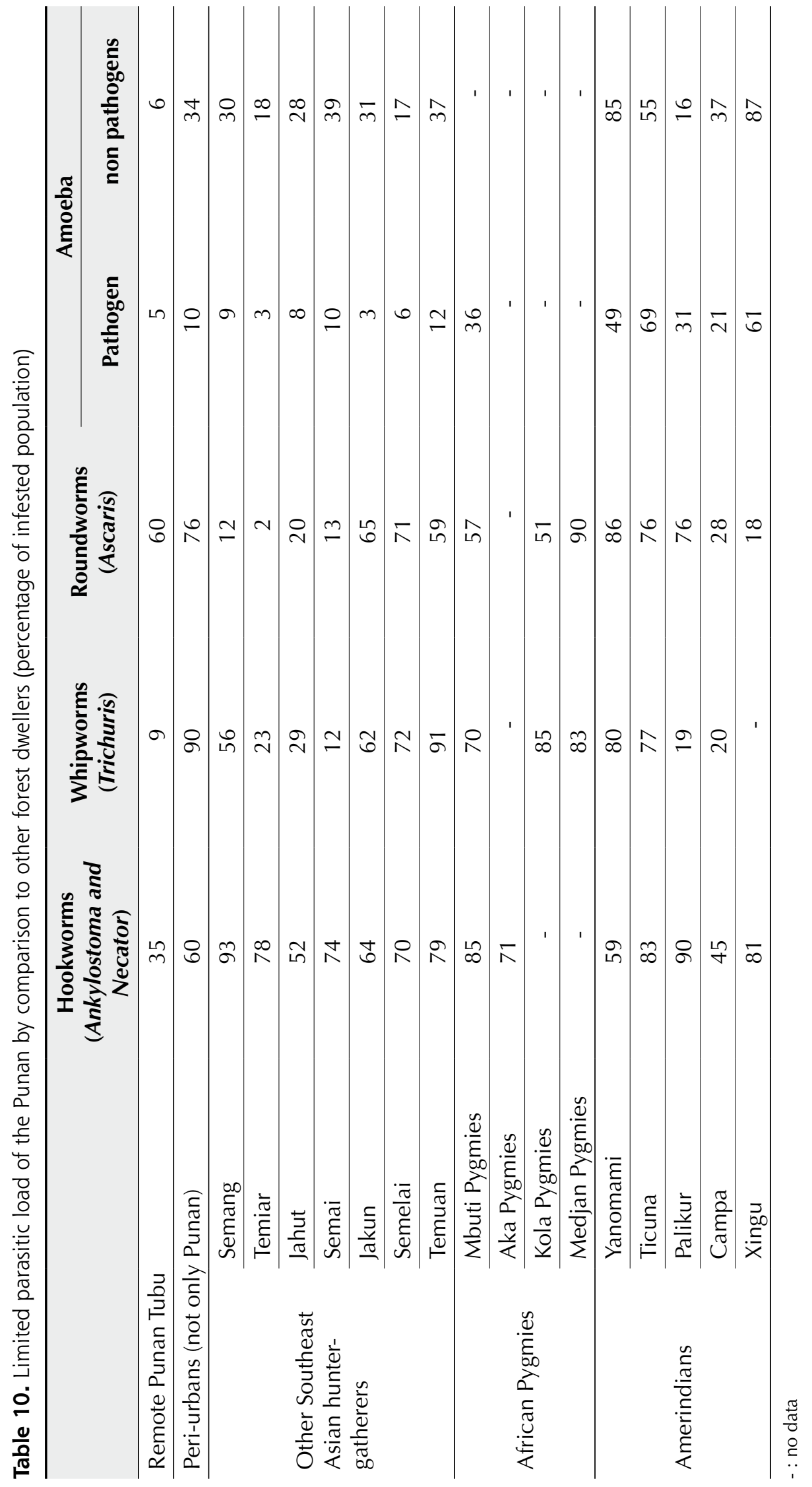




\section{Urine sampling and analysis}

471 people aged four years old and above corresponding to those who gave blood, with very few exceptions, voluntarily gave nearly $3 \mathrm{cc}$ of their urine in individual jars. Urine analyses were performed on fresh early morning urine samples. We used Bayer multiple reagent strips $\left(\mathrm{N}\right.$-Multistix $\left.{ }^{\circledR}\right)$, which enable a quick and easy check of the presence of glucose, ketones, blood, protein, nitrite, $\mathrm{pH}$, urobilinogen, bilirubin, leucocytes in urine as well as specific gravity. The results presented in Table 9 do not reveal particular problems for most of the components tested. The only obvious results are the high proportions of subjects with low $\mathrm{pH}$ (acid) urine and significantly high levels of detected leukocytes. The combination of low $\mathrm{pH}$ and positive leukocyte test suggests frequent kidney infection, kidney stones and, more importantly, chronic urinary infection, especially among women of remote villages who show the highest rates of infection.

\section{Stool sampling for testing parasitic load}

350 inhabitants of Long Nyau, Long Lemunjung and Rian Tubu voluntarily gave stool samples. Stools were collected in $50 \mathrm{ml}$ containers, then a small fraction was removed and kept in $15 \mathrm{ml}$ tubes in a solution of Mercurothiolate lodine Formol (MIF, for conservation) and Lugol 5\% (for colouration). Stool samples were firstly analysed in Puskesmas Malinau, then 'double-checked' by a private laboratory in Jakarta. If we exempt six samples taken in Respen Tubu, all of the samples come from upper Tubu.

The results for the Punan are shown in Table 10 and are compared with results published for other tropical forest hunter-gatherers of southeast Asia (mainly Orang Asli of Peninsular Malaysia), Central Africa (diverse Pygmy groups) and Amazonia. The rates of intestinal parasites we obtained for the Punan are significantly low compared to those reported elsewhere. Fecal pollution among the Punan villages is very limited (even if compared with transmigration villages of West Kalimantan) and this might be due to the use of the river for sanitation where feces are recycled by aquafauna.

\section{Clinical examination and medical treatment}

This component of the biomedical survey was undertaken in close partnership with the local health services. Dr Dwipa Anakangunggede from Pulau Sapi accompanied us in May-June 2003 and ensured systematic and detailed clinical examination of all the people and relatives who were measured and gave blood and urine $(n=525$ people) samples. Medical treatment was provided for free when needed. Information concerning the health status of examined people and treatment provided ad hoc were recorded on individual sheets.

Simultaneously with these studies, and continuing during 2005 and 2006, we proceeded, in close partnership with the local health services and the humanitarian organisation Doctors of the World, to perform repeated clinical examinations (a total of 2,280 examinations were made in 50\% of the total population and only on patients who spontaneously expressed their will to consult the doctor) and provide medical care to the remote Punan Tubu communities when necessary.

The most reported diseases are noncommunicable diseases that tend to affect adults and that are revealed by symptoms like flu, fever intestinal pain, hypotension and vertigo. Acute respiratory infections are also frequent, especially among young patients and several probable cases of malaria were noted. When malaria was clinically suspected, the patient was tested with Paracheck ${ }^{\circledR}$, an inexpensive, rapid and reliable on-site diagnosis to Plasmodium falciparum malaria. If the test was negative, the patient was treated for $P$. vivax malaria (no on-site test yet available to detect this form of malaria).

Many people who asked to be examined expressed very minor and fuzzy symptoms and were actually revealed to be in perfectly good health. Diarrhea and cutaneous diseases were reported only occasionally. A few cases of tuberculosis were suspected, but more detailed analyses in a hospital environment are necessary to confirm the diagnosis.

Several cases of over-infected vesicular lesions observed occasionally in a single location may suggest a local epidemic of smallpox. In 
176 CHAPTER 11

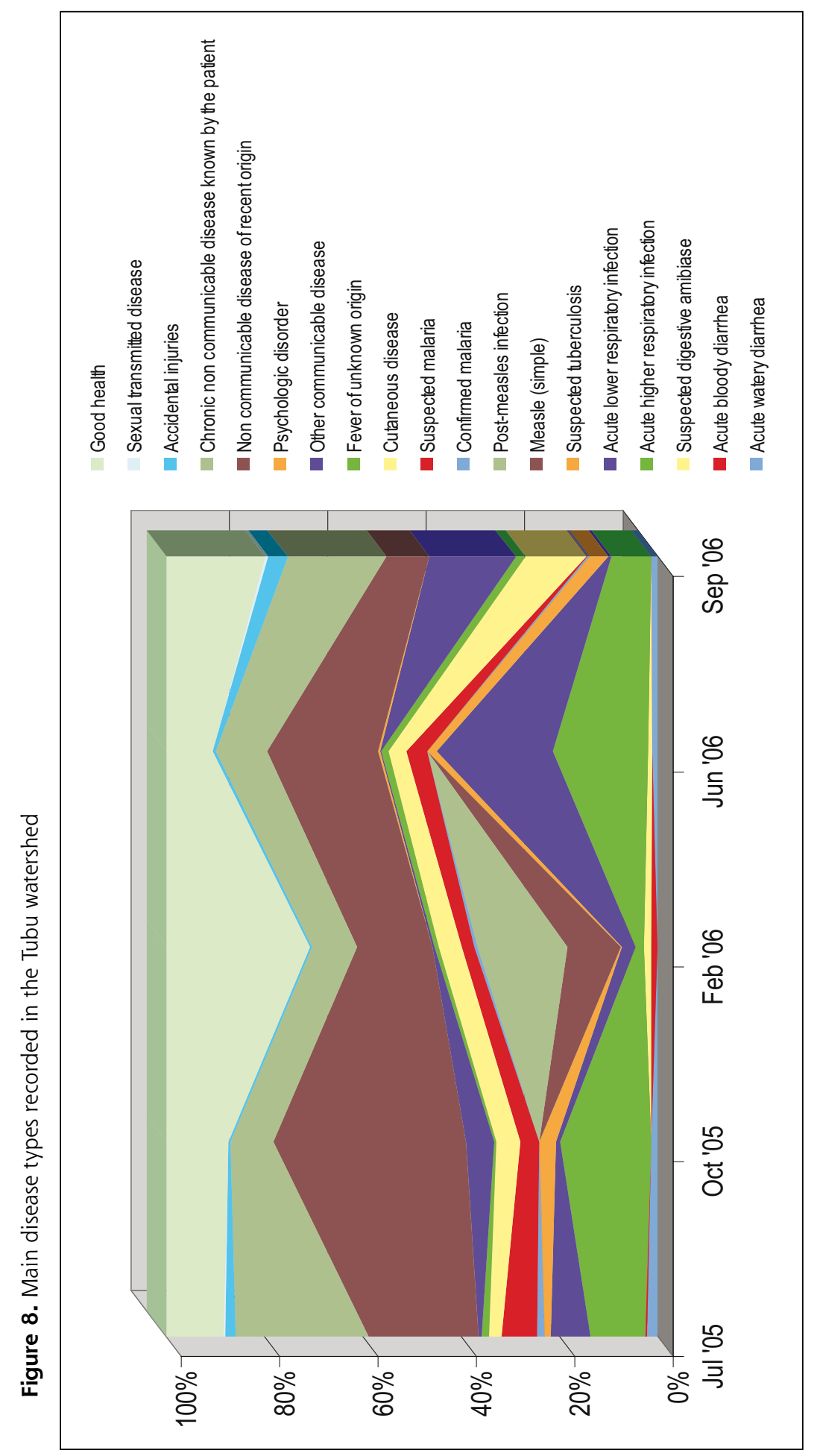


the same location, we also noticed a highly contagious epiphenomenon of throat infection. We also observed a few cases of kuam, a kind of vesicular, eruptive and painful lesion that affects the mouth of newborns, sometimes making it impossible for the baby to breastfeed. The state of teeth and auditory canals is often unhealthy. Such chronic problems are no doubt due to poor body hygiene, and may largely contribute to the chronic headaches, vertigos and backaches that people complain about so frequently. A preventive intervention regarding ear and dental health will be considered in the future.

\section{Capture of mosquitoes and ectoparasites (ticks)}

We also conducted seasonal night catches of mosquitoes by using mini light traps in order to monitor the exposure to malaria and to identify the vectors. We found two species of Anopheles that are the main vectors of malaria in the Tubu watershed.

In partnership with the Research Unit 034 of IRD 'Emerging viral diseases and information systems' that aims to understand the ecology and epidemiology of germs and disease emerging or reemerging in a changing environment, we harvested these ectoparasites on carcasses of wild boars and sambar deers. Ticks are known as potential vectors of viruses that may possibly be transmitted from wild boars to humans. Considering the long-term dependency of the Borneo population on wild boar meat (almost 40,000 years), we may consider the possibility that the foraging peoples of Borneo have adapted to local forms of viruses, and such potential adaptation may be of vital importance for general human health in response to new emerging viral diseases. Tick samples were sent to the University of Mahidol in Bangkok, where a research team from IRD is studying new emerging viruses. They found two new flavi-viruses in the ticks we sent them. Further analyses are still in progress and we cannot elaborate further at this stage.

\section{DISCUSSION}

From the studies we conducted on diet and disease among the Punan Tubu, we can summarise the following major points:
- The diet of remote Punan villagers is much better than those of peri-urban Punan, especially as sources of proteins are more diversified. The problem the remote villagers face is that they are not self-sufficient in rice and they need to shift to cassava as their major staple food for several months preceding the new rice harvest. They also seasonally depend on sago during occasional migrations into the forest (mufut).

- Body Mass Index and Body Fat Data reveal that fitness is also better in remote villages. Being seasonally underweight affects women similarly in both locations, and the origin of this malnutrition is probably cultural as it affects principally older people. Rare cases of obesity were observed only among periurban women.

- Biomedical analyses do not reveal serious problems among the Punan populations. The prevalence of malaria is not higher than in other places of Kalimantan, but is more acute among the Punan who, as former huntergatherers, have not developed efficient immunity again vector-borne diseases. The parasitic load is much lower than in any other groups of forest peoples living in similar conditions throughout the world. This proves that the forest and water environments of the Punan are quite healthy. Urine analyses do not reveal serious problems, apart from high proportions of acid $\mathrm{pH}$ and positive leukocyte tests that may suggest frequent kidney infection, kidney stones and urinary infection.

- If, on one hand, the remote Punan are globally much better off in terms of diet and fitness than the Punan living near the city, on the other they are more exposed to drastic changes of seasons. For them, access to market to compensate for a seasonal lack of resources from the forest is very limited. The risks to health are due neither to malnutrition nor to a dangerous life in the forest. Major risks are due to infectious epidemics coming from outside their forest and that are irregular and unpredictable.

- Our study demonstrated high fluctuations between seasons within the same year. People respond to these intra-annual fluctuations through a diversified production system that combines agriculture,fishing, hunting andgathering and by a seasonal mobility 
(migration into the forest when resources at the village are scarce).

- The dipterocarp forests of this part of Kalimantan are also characterised by high fluctuations from one year to another. Such irregular inter-annual fluctuations may drastically affect resource availability during certain years and provoke unpredictable epidemics against which remote forest people have little or no immunity. One possible answer to erratic epidemics would be systematic vaccination campaigns, but this requires a continued refrigeration of the vaccines that is difficult to implement when conditions of access are difficult. However, inter-annual fluctuations are nearly impossible to assess without conducting fieldwork over a very long period of time. Such studies are not only costly and time-consuming, they are also socially and ethically problematic as local peoples expect short-term feedback from research.

Our comparison of distinct Punan communities that differ in their dependency on agricultural resources shows that the more remote the community, the more diversified the diet and the better the nutritional status and physical fitness. The contribution of forest resources to the dietary regime also decreases with proximity to the city. However, the higher dependency on agriculture is not the proximate cause of the deterioration of diet and physical fitness. Rather, it seems that the easier accessibility of cities and their markets has equivocal consequences. It can be an advantage during years of drastic food shortage, corresponding to an absence of mast fruiting in the Dipterocarp forests of Borneo, which have dramatic consequences for the ecological success of forest dwellers. Markets also ensure a more regular supply of a wide range of vegetables and fruits, but also of dairy products and eggs. For instance, calcium and micronutrients provided by these types of food greatly contribute to the prevention of dental problems. When combined with a minimum of education and information on hygiene and sanitation, their role in improving dental health and consequently attenuating child morbidity should not be neglected. But improved access to markets results in greater dependence on a regular cash income and more pronounced individualistic behaviour that jeopardises the fundamental collectivist principle of the Punan culture, an efficient adaptive response to seasonal food uncertainty during their nomadic past.

Industrialisation and urbanisation accompanying the economic boom in the interior of Borneo have had an impact on the dietary habits of the people. As we have shown in this chapter, there is a trade-off between the advantageous new crop resources, which bring with them a sedentary lifestyle, and the detrimental effects of modification in the availability and distribution of wild food resources near permanent settlements. Such changes affect nutritional status, as clearly shown by the peri-urban Punan, who tend to have an excess intake of energy-dense foods, especially snacks that are rich in fat and free sugars but low in complex carbohydrates. Evidence from epidemiological studies has confirmed the link between such diets and the risks of chronic degenerative diseases of middle and later adult life, especially cardiovascular diseases and certain types of cancer (Colfer et al., 2006). Although they are not yet a critical problem for the Punan, other nutritional disorders, such as anemia, excessive weight, hypertension, elevated cholesterol levels and diabetes, are emerging signs of dietary imbalance.

Most recent archaeological and anthropological literature on the 'paleolithic diet' hypothesis (The Paleolithic diet page) advocates that the food regime of former hunter-gatherers was relatively healthy: it was rich in protein and fibres, while poor in salt, milk and sugar. In the strict nomadic lifestyle of earlier times, migrations were performed along extended and linear territorial trails that not only reduced food hazards (Dounias and Leclerc, 2006), but also ensured good physical fitness. This resulted in low body adiposity and prevention of cancer and cardiovascular complications. However, such relatively good fitness was achieved at the expense of a high mortality and a relatively short life span (Eaton and Eaton, 2000). The legendary good diet and fitness of the former hunter-gatherers does not resist their brutal jump into modernity. Even if it does not have a direct effect on their health, the rapid conversion to farming has certainly contributed to their imbalanced dietary regime. In the long run, this may ultimately compromise their health status and ecological success. 


\section{CONCLUSION}

Forest ecosystems are dynamic, as are the human societies depending on the forest. Forests dwellers have had to adapt to permanent changes of forest ecosystems. However, the changes that they face today are much more extreme and radical than those they have experienced in the past. As deforestation, drastic modification of resource availability and the invasive influence of the cash economy occur more rapidly, social, cultural, economic and political systems become increasingly difficult to accommodate. The choices made by foraging societies are no longer validated by experience, and are revealed to be costly in terms of ecological success.

Social change may not necessarily be accompanied by a well-balanced biological optimum. It may sometimes invalidate defence mechanisms and nutritional status. The imbalanced biological side may in return compromise the social and cultural integrity of the society.

However, increasingly poor diets and associated illnesses are only symptomatic warnings, alerting us to the ecological and socio-cultural maladaptations that these societies are undergoing. More acute than malnutrition and diseases are the ill-effects caused by social prejudice which is a source of insecurity and discrimination. The healthy future of former hunter-gatherers depends today on factors such as access to education and the acknowledgement of their traditional rights. Providing medical assistance to cope with the malnutrition and diseases of these people is moral evidence that would only provide shortterm respite from the immediate symptoms. However, this should not overlook other more helpful log-term interventions that consider the ecological, social, political and economic drivers of change that indirectly affect the health of forest peoples. Improving their health is not in the hands of medical doctors alone.

Data on nutritional ecology in such environments are difficult to obtain, and too few results are available in the literature to support solid diachronic as well as synchronic comparisons. There is definitely a need for further long-term studies on these issues. But time is short, and there is also an urgent need for immediate action in favour of the rapidly changing populations and environments of the forest.

\section{REFERENCES}

Chivian E. 2001. 'Environment and health: 7. Species loss and ecosystem disruption. The implications for human health'. Canadian Medical Association or its licensors 164: 1, pp. 66-9.

Colfer, C., Sheil, D., Kaimowitz, D. and Kishi, M. 2006. 'Forests and human health in the tropics: some important connections'. Unasylva. 57(224): pp. 3-10.

Dounias E. (in press). 'Wild boar, seasonality, and diet. Coping with changes in food supply among the Punan Tubu of Eastern Kalimantan'. In Dounias E., Garine, I. de, Garine, V. de. (eds). Anthropology, Nutrition, and Wildlife Conservation. Guadalajara: University of Guadalajara, Estudios del Hombre.

Dounias E. and Colfer, C.J.P. (in press). 'Sociocultural dimensions of diet and health: Examples from Central Africa and Indonesia'. In Colfer, C.J.P. (ed). People, health and forests. London, Earthscan Books.

Dounias E. and Froment, A. 2006. 'When forestbased hunter-gatherers become sedentary: consequences for diet and health'. Unasylva 224, 57(2): pp. 26-33.

Dounias E. and Leclerc, C. 2006. 'Spatial shifts and migration time scales among the Baka Pygmies of Cameroon and the Punan of Borneo'. In de Jong W., Lye, T.P. and Ken-Chi, A. (eds). The social ecology of tropical forest: Migration, populations and frontiers. Kyoto, University Press and Trans Pacific Press, pp. 147-73.

Eaton, S.B. and Eaton, S.B the 3rd.. 2000. 'Paleolithic vs modern diets - Selected pathophysiological implications'. European Journal of Nutrition 39: pp. 67-70.

Internet website The Paleolithic diet page. What the hunter/gatherers ate http://www.paleodiet.com

Lee R.B. and Daly, R. (eds). 1999. The Cambridge encyclopedia of hunters and gatherers. Cambridge University Press, Cambridge. 
Panter-Brick C., Layton, R.H. and RowleyConwy, P. (eds). 2001. Hunter-gatherers. An interdisciplinary perspective. Cambridge University Press, Cambridge.
Patz, J.A., Graczyk, T.K., Geller N. and Vittor, A.Y. 2000. 'Effects of environmental change on emerging parasitic diseases'. International Journal of Parasitology 30: pp. 1395-405. 


\section{CHAPTER 12 TOWARDS SUSTAINABLE FOREST MANAGEMENT AND IMPROVED LIVELIHOODS IN TROPICAL FORESTS: LESSONS AND CONCLUSIONS}

Petrus Gunarso, Kresno Dwi Santosa, Charlie Shackleton, Terry Sunderland, Bruce M. Campbell, Hari Priyadi, Patrice Levang, Douglas Sheil and Edmond Dounias 


\section{INTRODUCTION}

This chapter synthesises the key themes emanating from the work in Malinau Research Forest (MRF), as pointers towards the sustainable management of tropical forests and positive outcomes for forest-based livelihoods. This book, a summary of the research findings from Phase II, and the technical report from Phase 1 (CIFOR, 2002) both present a picture of extreme change, from a period of centralised control characterised by large-scale logging operations to a period, following decentralisation, dominated by many smaller operators. This has resulted in local communities getting more of the action, and the local authorities becoming more powerful and influential. A new district has emerged, roads and bridges have been constructed, the district capital has grown at unprecedented rates and new actors entered the system (e.g. potential traders in carbon, investors in proposed oilpalm plantations). Major unanticipated changes may be common in dealing with large complex natural resource systems (see the chapter on Malinau in Sayer and Campbell, 2004).

\section{EMERGING ISSUES IN SUSTAINABLE FOREST MANAGEMENT}

\section{Implementing decentralisation policies}

Decentralisation has shifted the balance of power and introduced new actors in the logging and governance arena. When research was initiated in Malinau in the middle to late 1990s, the perceived problems were related to industrial logging by large state companies. The key research concerns at that time addressed damage to the local environment by logging, concerns about the sustainability of timber supplies from the ostensible permanent forest estates and the lack of benefits reaching local inhabitants. Shortly after the passing of Indonesia's decentralisation laws on 1 January 2001, small-scale logging became rampant throughout Indonesia, particularly in Malinau as the district is close to high-value timber markets in Malaysia. In early 2000 many small-scale logging permits covering areas of between 100-5,000 ha each were allocated to hastily formed small companies. This resulted in extraordinarily high levels of intense, unsustainable timber extraction and considerable land and resource conflict. Later, this system of logging was withdrawn, partially due to pressure from the national government. The lack of technical capacity, financial resources and political will at the district level initially limited any attempt to manage natural resources on a sustainable basis. There currently remains considerable confusion and uncertainty as to who, from local to national levels, is primarily responsible for the varying aspects of natural resource management.

The focus of the research shifted from stand-level work on improving logging practices (Priyadi et al., this volume) in Phase I to a more districtlevel focus on improving the understanding of landscape dynamics, and contributing tools, approaches and information for spatial planning and decision-making (Sheil et al., this volume; Wollenberg et al., both chapters, this volume). A wide variety of research has led to greater understanding of the possible trajectories of change, and a simulation model has been created to demonstrate different scenarios for land use (Suwarno et al., this volume).

When Phase II commenced, the district had almost no capacity for spatial land-use planning. Considerable effort was exerted on establishing a district-level GIS laboratory, compiling the appropriate spatial information and building the capacity of the local authorities charged with this activity. As reflected on in both chapters by Wollenberg et al., however, land-use planning can be unconnected to what actually happens on the ground, a situation that is likely to be common in remote forested landscapes characterised by weak governance and limited human capacity. As presented in this book, we propose five principles for a more focused land-use planning process and describe how they played out in Malinau: (a) linking local knowledge, experience and aspirations of different groups to formal land-use planning and decision-making; (b) using system frameworks for understanding land use as a process and anticipating change; (c) having leadership and institutions with adaptive capacity and bottomup participation; (d) analysis and intervention at multiple levels; (e) explicit activities and procedures to build capabilities. The approach 
emphasised finding ways to make local-level, practical knowledge and activities accessible to and usable by district decision-makers and communities.

Given the diversity of players at different levels and the often skewed power relations between them, a focus of the work was how best to undertake negotiations among the multiple stakeholders in such arenas. By adopting a learning process with the communities, one of the research teams was able to adapt to the swiftly changing circumstances in the district. The learning cycle was rapid, allowing for several cycles in a few years. At the national-district nexus, analyses of the impacts of decentralisation were undertaken, and facilitators worked with different groups to promote dialogue and action at the district level. Institutional analyses indicated the problem of the local legal system, and key players identified the need for assistance with drafting laws and regulations. This was followed by workshops on drafting legal texts so as to improve preparation of local laws.

Much of the work can be said to be leading to the empowerment of local communities, who are politically weak in the face of logging companies, district officials and entrepreneurs. The participation of Punan and women in our community work has visibly increased in Malinau. Communities have learnt better ways of stating their needs and what they imply to outsiders. This allows them better to articulate their preferences in various forums, notably more sophisticated land-use visions and spatial plans.

\section{Securing forest livelihoods}

Tropical forests are under threat globally. Whilst the rates of deforestation are slowing in some regions, there remains a net annual loss (FAO, 2005). The global and local-level drivers of deforestation are complex and differ from region to region, and even between sites within the same region (Achard et al., 2002). Much of the argument against deforestation has been led by conservation agencies concerned with biodiversity loss, although the magnitude of biodiversity losses has been questioned by Sheil et al. (this volume). However, such debate has seldom considered the local livelihoods of forest dwellers and how they perceive the arguments in favour of logging or for conservation. Typically a mix, or mosaic, of land uses seems the ultimate compromise and trade-offs are inevitable (Boedhihartono et al., 2007). For example, Suwarno et al. (this volume) model the land-use options available at a district level, particularly the potential conversion of forest to oil-palm plantations, to promote local economic growth whilst simultaneously conserving as large an area of forest as possible for biodiversity conservation and local use. Yet Levang et al. (this volume) and Sheil et al. (this volume) indicate that relatively little of the MRF area is suitable for plantation development, a fact that as yet seems not to have been recognised by planning agencies. The same applies at the local level (Limberg et al., this volume), where it is acknowledged that the majority of local village committees wish to implement a system of land zoning which consists of plantations, swiddens, production forest and some protection forest.

The results from work in the MRF indicated that forest-dwelling communities have considerable knowledge about the forest, at both the species level and system functioning (Sheil et al., this volume), corroborating the growing literature indicating the considerable extent of local ecological knowledge by rural peoples in managing their landscapes and species (e.g. LaRochelle \& Berkes, 2003; Casagrande, 2004; Phuthego \& Chandra, 2004). This knowledge is constantly mobilised to sustain their local livelihoods, both for collection of NTFPs as well as in swidden agriculture. However, Levang et al. (this volume) reveal that by conventional measures of well-being, forest livelihoods are more vulnerable than non-forest dwellers, as is the case elsewhere in the tropics (Wunder, 2001; Shackleton et al., 2007). Education and health levels are low, as is formal income. Yet forest dwellers aspire to acquire many of the trappings of modernity, primarily access to services such as clinics and education, but also ownership of electrical goods, outboard engines, chainsaws and the like. As commented by Levang et al. (this volume), local livelihoods remain dependent upon the forests, but the nature of the dependency has changed from subsistence needs to a more market-oriented approach. 
Paralleling the finding that access to markets is a key factor in the extent and value of household trade in forest goods (Pyhälä et al., 2006; Mamo et al., 2007), is that the conventional measures of well-being of the forest communities are also strongly related to accessibility to Malinau Town, the local regional centre (see Levang et al., this volume). Remote communities rely almost exclusively on forest products and swidden agriculture for their needs. In settlements closer and more accessible to regional towns, the proportion of income generated external to forest-related resources increases, as recorded elsewhere (e.g. Shackleton et al., 2002; Stoian, 2005). However, this does not necessarily reduce livelihood vulnerability. An element of vulnerability persists in forest livelihoods due to unpredictable climate which affects rice yields, logging impacts on water quality, changes in population, abundance of key fruits or bushmeat species, the declining abundance of NTFPs such as gaharu, and so on. Yet for households living in or close to Malinau Town, these uncertainties are exchanged for other issues relating to uncertain employment prospects because of low education levels, undeveloped links with social and economic elites, price fluctuations of staple goods such as rice, the loss of cultural identity and fluctuating markets for forest goods. Consequently, the forest and its products remain a major safety net for households even in accessible settlements, and suggest the need for knowledge and experience of the forest to be maintained. This parallels work in both Central America and South Africa (McSweeny, 2004; Paumgarten, 2006; Stoian, 2005). Ultimately, reducing vulnerability and sustaining livelihoods, whether deep in the forest, on the periphery or in town, are a function of ensuring that people have a range of options available to them, especially, but not solely, during times of vulnerability.

\section{Alternative uses for forest resources}

It has long been appreciated in research circles that the value of forests, tropical and otherwise, consists of more than just the timber which they contain (for example, see Peters et al., 1989). Tropical and dry forests are endowed with some of the highest concentrations of terrestrial biodiversity. This vast array of species offers many tangible products to forest users, such as medicines, food, fibres and construction timber.
These other products have been given a variety of labels, such as minor forest products, secondary products or non-timber forest products (Belcher, 2003), with the last term in widest use.

The research at MRF has identified hundreds of forest species used by local communities (Sheil et al., this volume). Most are for local consumption, but many are also traded in local and regional markets, such as game, fish and gaharu, with the last being particularly significant. The extent of trade is strongly related to accessibility to markets, which are situated mainly in local towns. Many studies around the globe, including at MRF, have now indicated that the combined potential value of all these resources in the forest can be significant, at times greater than the value of the primary commercial focus of the land, such as logging or livestock (e.g. Peters, et al., 1989; Melynk and Bell, 1996; Shackleton, 1996), although realisation of that value depends upon a number of factors, including market access (Pyhälä et al., 2006). The challenge remains how to manage extraction of commercial timber in a way that has only limited impact on the sustainable supply of these non-timber forest resources.

However, with integrated land-use planning and modern management it need not be a case of having to choose between commercial timber or non-timber forest products. Timber harvesting approaches, such as Reduced Impact Logging (Priyadi et al., this volume), can limit damage to the forest and the wider environment, thereby accelerating regeneration, with both outcomes ensuring that some NTFPs remain available (Barreto et al., 1998; Holmes et al., 2002). Moreover, commercial logging operations improve accessibility and abundance of some NTFPs species, especially those that thrive in secondary forest or areas opened up by logging operations, such as some species of rattan. For example, Meijaard and Sheil (this volume) detail how approximately one-quarter of the wildlife species investigated actually increased following logging and that there had been no local extirpation of any species, as has been often assumed. Additionally, commercial logging and swidden creation results in an abundance of waste wood. Iskandar et al. (this volume) have shown that this wood can be put to good use at household levels and can 
provide promising commercial opportunities for charcoal manufacture and distillation of wood liquors/ wood vinegar.

Within the last decade, new values of forests and other systems, i.e. the ecosystem service values, are being elucidated, quantified and communicated (Constanza et al., 1997; Higgins et al., 1997; Portela \& Rademacher, 2001). These include services such as water provision, carbon sequestration and pollination. In fact, Sumarno et al. (this volume) demonstrate how carbon payments could compete strongly with oil palm in terms of generating income for the Malinau district. Adding this knowledge to that regarding the value of non-timber forest products adds new weight to the need for sustainable forest management, which must happen at all levels of management and government. In Malinau, these have been appreciated at the local level, where some village structures (e.g. at Setulang) have opted to afford protection of a significant proportion of their forests from commercial logging, primarily because of their need to ensure good water quality. Given current global warming estimates, the carbon sequestration value of forests is being increasingly recognised as an important function of tropical forests and is a key reason why they need to be protected from large-scale land transformation (Adger et al., 1995; van Beukering et al., 2003). The negative impacts of forest clearance in many places on the health of local people should also not be underestimated (Colfer et al., 2006; Dounias, this volume).

Cultural values are also widely appreciated, but difficult to assign a monetary value as with tangible forest products, and so they have rarely been included in calculations of the total economic value of a particular region. None the less, cultural values are clearly significant. For example, Seidl and Moraes (2000) estimated cultural aspects of forests in a region of Brazil to contribute $7.3 \%$ of total economic value, whereas in the dry forests of Zimbabwe, Campbell et al. (1997) reported that cultural use of environmental goods accounted for between $16 \%$ and $29 \%$ of the value accruing from total use of the environment. At the MRF such a valuation has not been undertaken, but there are clear cultural values, as evidenced by the perceptions of the forest by local people (Sheil et al., this volume) and the recognised need to respect sacred burial sites in the forest (Limberg et al., this volume).

However, translating research knowledge regarding the wealth and cultural value of products in forests into policies and ultimately land-use decisions has taken time. Many research and advocacy groups lament that these issues still seem to be ignored by government and planning agencies, with the focus still firmly on timber as the primary use and value of forests. None the less, there has been significant progress with implementation of decentralisation policies and management plans (Limberg et al., this volume), as well as global reporting protocols, such as FAO's global State of the Forests Report, which serve to raise awareness.

\section{Intensification of forest use}

The various chapters in this book have described the many and various uses of forests and their resources. The type of use differs between settlements, especially in relation to proximity to regional centres, as well as land potential. None the less, a clear theme of the different studies presented in this volume is intensification of forest use, evident at both the species scale and the land-unit scale.

At the land-unit scale, communities are being faced with the need to zone the land under their control and to decide how to optimise the utilisation of each zone (Limberg et al., this volume). This has happened in the past, but in a less formal manner and always with uncertain boundaries and the understanding that certain uses could always expand into relatively untouched forest if required. But the demarcation and allocation of specific forest areas to specific villages, and the need to ensure that the aspirations of all forest users are considered and (as far as possible) met, means that there is limited room for land expansion. Consequently, intensification is a logical option, especially in the face of parallel forces towards greater commodification and integration in the formal cash economy (Levang et al.; Limberg et al., both this volume), to some extent typifying the Boserup (1965) model of intensification in agriculture. Consequently, communities have to consider allowing part or all of their forests 
to be logged, and many are eager to do so because of the cash royalties it brings. Rotation rates of swiddens are declining, with perceived declines in yields, demanding greater inputs and management. Replacing forests with plantations is seen as an attractive option (Suwarno et al., this volume). Even communities with a strong sense of identity and respect for the forests and what it provides, are pressed to establish secure means of generating income, with plantations as a primary option.

At the species level it is apparent that several resources have been over-exploited, either because of logging operations or heavy, targeted harvesting by local traders. For example, Levang et al., (this volume) describe how gaharu used to be relatively abundant, but that now harvesters can search for days with a limited harvest, and Meijaard and Sheil (this volume) report that some mammal and bird species declined after logging. However, intensification need not concentrate solely on forest conversion but can also be accompanied by increased efficiencies of use, leading to less wastage. For example, the use of slash waste for charcoal or wood vinegars may well provide a livelihood opportunity for some households (Iskander et al., this volume).

\section{Reduced impact logging}

In the tropical forests of south-east Asia, the forest canopy is dominated by species within the family Dipterocarpaceae. Up to $80 \%$ of the timber species found in south-east Asian forests belongs to this family. As the dipterocarps are also the main commercially exploited timber, harvesting rates commonly exceed more than 10 trees per hectare (or $100 \mathrm{~m}^{3} / \mathrm{ha}$ ). In standard logging operations, this intensity of exploitation commonly damages more than $50 \%$ of the original tree population. Hence, there are considerable concerns surrounding issues of sustainability of logging in Indonesia in particular. Prompted by a growing awareness of the need to protect forest ecosystem functions and maintain biodiversity in production forests, concerns have been raised as to whether logging can be compatible with other forest services. Efforts to promote more sustainable timber-harvesting techniques have promoted the implementation of Reduced Impact Logging

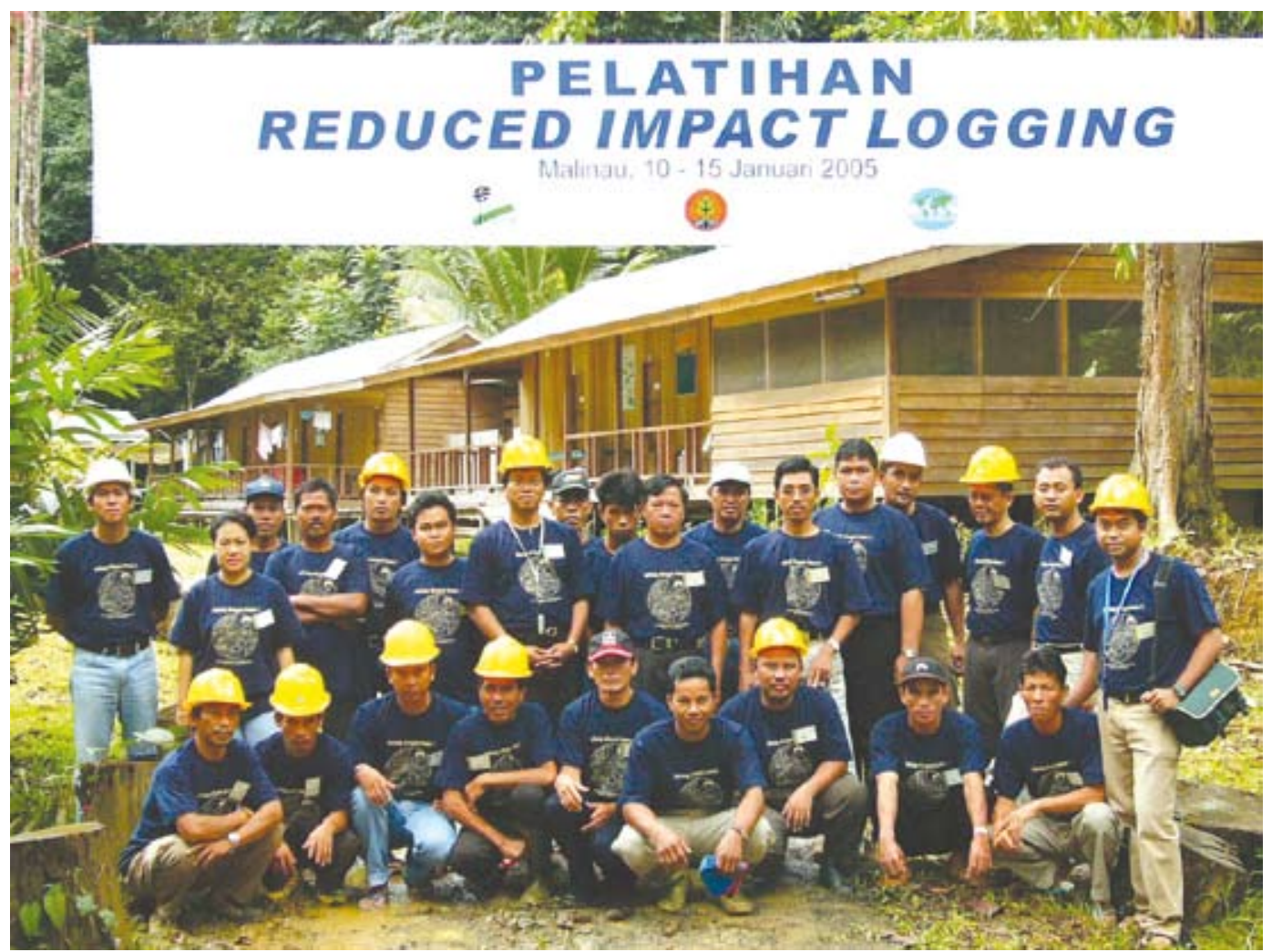

RIL training in Malinau (Photo by MRF team) 
(RIL) (Priyadi et al., this volume). The objective of RIL is to reduce soil disturbance, damage to residual trees (Sist et al., 2003) and impacts on the wider biodiversity (Meijaard and Sheil, this volume) as well as ensuring future production of timber. RIL has been tested in a number of sites in south-east Asia and has shown that damage to the original stand can be reduced by $30-50 \%$ and can probably shorten the logging cycle due to better post-harvest regeneration.

Central to the implementation of RIL is a clear set of guidelines which define the actions necessary to achieve it. The guidelines presented by Priyadi et al. (this volume) conform to the guidelines of the TPTI (Tebang Pilih Tanam Indonesia, or Indonesian Selective Cutting and re-planting System). The guidelines concentrate on reducing the impacts of tree felling and heavy machinery on the residual stand and forest soil as well as providing 'best-practice' training for tree fellers, tractor operators and forest planners.

The work of CIFOR in the Malinau Research Forest on RIL has made a significant impact on the process of decree issuance, whereby all timber companies in Indonesia should now be implementing RIL in their concessions (Gustafsson et al., 2007). Furthermore, for timber companies, the implementation of RIL techniques will generate important credit to the process of achieving forest certification (Ruslim, pers. comm).

However, the success of RIL implementation in the field will ultimately depend mainly on the motives and intentions of logging companies. At present, the common belief among loggers is that RIL techniques cost more to implement, in simple economic terms, than conventional timber-harvesting operations, and this is certainly affecting the adoption of RIL by many companies, including those operating in Malinau. With timber markets currently increasing the demand for timber from more sustainable, or certified, sources, the reluctance to adopt RIL may change in the short term.

\section{Prompting conservation of forests and resources}

Although there are undeniable pressures for intensification of forest use through logging and land transformation to swiddens and plantations, the benefits of conservation are well appreciated and understood by local communities and officials (Limberg et al., this volume). All community groups consider intact forest as the most valuable to meeting their varied needs for subsistence and income generation (Sheil et al., this volume), as well as maintenance of local cultures and traditions. Some communities have zoned significant proportions of land under their jurisdiction as 'protected forest' and many have regulations regarding the harvesting of certain species (Limberg et al., this volume). Interestingly, there remains a great deal of ambivalence about the benefits of logging, with only $56 \%$ in favour of timber exploitation, even before a targeted conservation awareness campaign (Sheil et al., this volume). This proportion declined further as a result of a small, temporary awareness campaign, suggesting fertile scope for changes in conservation-related knowledge, attitudes and practices if a sustained and concerted campaign is mounted (Boedhihartono et al., 2007).

However, the integration of conservation principles and practices into other land uses in the forest landscape, such as swidden agriculture and plantation establishment, remains to be explored so that the impacts of these activities can be minimised (Boedhihartono et al., 2007). Logging stands out in this respect where there is considerable knowledge and growing pressures on timber companies to log according to best environmental practice, typified by Reduced Impact Logging (Priyadi et al., this volume).

In balancing the need for conservation with that for sustainable livelihoods, it has to be accepted that areas of forest will be lost. The challenge becomes how to (i) integrate conservation areas and practices into the wider land-use process, and (ii) intensify land use as a means to minimise the areas of new forest converted or otherwise altered (Suwarno et al., this volume). This needs to happen at the planning or district level, as well as at the community and household level. Centralised planning helps to examine the balance and trade-offs between different land uses. For example, Suwarno et al. (this volume) explore the extent of plantations that are proposed, as well as the magnitude of investment in intact forest to avert transformation. This sort of exercise now needs to be iterated with local role players, including local communities. At a 
finer scale, local communities and households need to collaborate so that adjacent land uses are complementary and minimise fragmentation of the forest. Interestingly, modelling of forest use and total economic value under three scenarios in Sumatra indicated that selective use and conservation resulted in relatively similar returns, with both being approximately $30-36 \%$ higher than logging (van Beukering et al., 2003).

But conservation at the local scale is not just about zoning of land. It also relates to how land and resources are managed to meet a specified output. Communities already have regulations or conventions that have conservation significance (e.g. regulations relating to the harvest of certain species, or at certain times of the year, where land can be cleared and so on (Limberg et al., this volume). Approaches such as eco-agriculture and agroforestry could well have conservation benefits within the productive swidden areas, as well as plantations. Additionally the conservation significance of current logging practices needs to be examined. For example, the burning of slash waste and the slashing of lianas in logged areas to minimise residual stand damage all have deleterious environmental impacts (Priyadi et al., this volume). Mechanisms for the control of soil erosion also need to be further implemented (ibid.).

\section{Forests and health}

Forest ecosystems are dynamic, as are the human societies depending on the forest. Forest dwellers have had to adapt to permanent changes in forest ecosystems. However, the changes that they face today are much more extreme and radical than those they have experienced in the past. As rates of deforestation, drastic modification of resource availability and the invasive influence of the cash economy increase, social, cultural, economic and political systems become increasingly difficult to accommodate. The choices made by foraging societies, such as the Punan in Borneo, could be costly in terms of ecological success. Social change of this nature may not necessarily be accompanied by a wellbalanced biological optimum. It may sometimes invalidate defence mechanisms and nutritional status. The imbalanced biological side may in turn compromise the social and cultural integrity of the society.
Industrialisation and urbanisation accompanying the economic boom in the interior of Borneo have had an impact on the dietary habits of the people. As shown by Dounias et al. (this volume), there is a trade-off between the advantageous new crop resources, which bring with them a sedentary lifestyle, and the detrimental effects of modification in the availability and distribution of wild food resources near permanent settlements. Such changes affect nutritional status, as clearly shown by the peri-urban Punan, who tend to have an excess intake of energy-dense foods, especially snacks that are rich in fat and free sugars but low in complex carbohydrates. Evidence from epidemiological studies has confirmed the link between such diets and the risks of chronic degenerative diseases of middle and later adult life, especially cardiovascular diseases and certain types of cancer. Although they are not yet a critical problem for the Punan, other nutritional disorders, such as anaemia, excessive weight, hypertension, elevated cholesterol levels, and diabetes, are emerging signs of a dietary imbalance. This transition from the rural to urban milieu is taking place throughout the tropics, and Dounias (this volume) clearly highlights the health implications of such social and environmental change, despite the apparent material advantages.

\section{The role of research in managing forests for livelihoods}

The decentralisation process in administration and power in Indonesia has provided many opportunities for enhancing local livelihoods. However, the process is complex and at times poorly understood by the various actors, resulting in uncertainties and constraints (Wollenberg et al., Chapter 6). As such, the issue is fertile ground for the development of meaningful and rewarding synergies between research and management.

The chapters in this book present a synthesised picture of the myriad research results emanating from the research programme in MRF. Many scientific papers have also been published in peer-reviewed journals. Yet this research effort, understanding and outputs will have been meaningless unless the research process and outcomes influence knowledge, attitudes and practices of the different agencies in the region 
from local households and communities in the forest to district and national authorities, planners and logging companies (Sayer and Campbell, 2004). Clear evidence is presented that the research process has indeed offered new opportunities or insights to some local stakeholders. These include training courses in GIS technology (Suwarno et al. and Limberg et al., both this volume), the training of entrepreneurs able to manufacture charcoal from waste wood (Iskander et al., this volume), guidelines for Reduced Impact Logging (Priyadi et al., this volume), changed perspectives on conservation (Sheil et al., this volume), and increased knowledge on the local use and composition of the forest (Levang et al.; Limberg et al., both this volume). In addition, the model described by Suwarno et al. (this volume) supported policy changes on land use in Malinau which tempered the local government's enthusiasm for oil palm and spurred their interest in investigating payments for environmental services (PES) schemes (Dwi, pers. com. 2007).

However, the research process can have far greater impacts when integrated into higherlevel planning and decision-making processes, at all scales, including the Malinau district, Indonesia and globally. The very publication of this book will help disseminate key messages to other researchers, development agencies and forestry donors. In this regard, the research programme at MRF, whilst context-specific, acts as a model for other forests and communities in the world facing similar challenges. Thus, the process of ensuring the research outcomes of this programme in MRF become the basis for a viable model of sound land-use planning and sustainable livelihoods elsewhere, has only just begun.

\section{REFERENCES}

Achard, F., Gallego, J., Richards, T., Malingreau, J.P., Eva, D., Stibig, H.J., and Mayaux, P. 2002. 'Determining deforestation rates of the world's humid tropical forests'. Science, 297: pp. 999-1002.

Adger, N.W., Brown, K., Cervigni, R. and Moran, D. 1995. 'Total economic value of forests in Mexico'. Ambio, 24: pp. 286-96.
Barreto, P., Amaral, P., Vidal, E. and Uhl, C. 1998. 'Costs and benefits of forest management for timber production in eastern Amazonia'. Forest Ecology \& Management, 108: pp. 9-26.

Belcher, B.M. 2003. 'What isn't an NTFP?' International Forestry Review 5, pp. 161-8.

Boedhihartono, A. K., Gunarso, P., Levang, P. and Sayer, J. 2007. 'The principles of conservation and development: do they apply in Malinau?" Ecology and Society 12(2): 2. [online] URL: http://www.ecologyandsociety.org/vol12/ iss2/art2/

Boserup, E. 1965. Population and technological change: a study of long-term trends. University of Chicago Press, Chicago.

Campbell, B.M., Luckert, M. and Scoones, I. 1997. 'Local-Ivele valuation of savanna resources: a case study from Zimbabwe'. Economic Botany, 51: pp. 59-77.

Casagrande, D.G. 2004. 'Conceptions of primary forest in a Tzeltal Maya community: implications for conservation'. Human Organisation, 63: pp. 189-202.

CIFOR. 2002. Forest, Science and Sustainability: The Bulungan Model Forest. Technical Report Phase I 1997-2001 ITTO Project PD 12/97 REV. 1 (F). CIFOR, Bogor, Indonesia. 167 pp.

Colfer, C., Sheil, D., Kaimowitz, D. and Kishi, M. 2006. 'Forests and human health in the tropics: some important connections'. Unasylva. 57(224): pp. 3-10.

Constanza, R., d'Arge, R., de Groot, R., Farber, S., Grasso, M., Hannon, B., Limburg, K., Naeem, S., O'Neill, R., Paruelo, J., Raskin, R., Sutton, P. and van den Belt, M. 1997. 'The value of the world's ecosystem services and natural capital'. Nature, 387: pp. 253-60.

FAO, 2005. State of the World's Forests. Rome. $153 \mathrm{pp}$.

Gustafsson, Lena., Nasi, R., Dennis, R., Nghia, N.H., Sheil, D., Meijaard, E., Dykstra, D., Priyadi, H., and Thu, P.Q. 'Logging for the ark: Improving the conservation value of production forests in South East Asia'. 2007. CIFOR Occasional Paper No. 47. 74 pp. ISBN: 978-979-1412-19-3. Bogor, Indonesia. 
Higgins, S.I., Turpie, J.K., Costanza, R., Cowling, R.M., le Maitre, D.C., Marais, C., and Midgley, G.F. 1997. 'An ecological economic simulation model of mountain fynbos ecosystems'. Ecological Economics, 22: pp. 155-69.

Holmes, T.P., Blate, G.M., Zweede, J.C., Pereira, R., Barreto, P., Boltz, F. and Bauch, R. 2002. 'Financial and ecological indicators of reduced impact logging performance in the eastern Amazon'. Forest Ecology \& Management, 163: pp. 93-110.

LaRochelle, S. and Berkes, F. 2003. 'Traditional ecological knowledge and practice for edible world plants: biodiversity use by the Rarámuri in the Sierra Tarahumara, Mexico'. International Journal of Sustainable Development \& World Ecology, 10: pp. 361-75.

Mamo, G., Sjaastad, E. and Vedeld, P. 2007. 'Economic dependence on forest resources: a case from Dendi district, Ethiopia'. Forest Policy \& Economics, 9: pp. 916-27.

McSweeny, K. 2004. 'Tropical forests product sale as natural insurance: The effects of household characteristics and the nature of shock in Eastern Honduras'. Society and Natural Resources 17, pp. 39-56.

Paumgarten, F. 2006. The significance of the safety-net of NTFPs in rural livelihoods, South Africa. M.Sc. thesis, Rhodes University, Grahamstown. 251 pp.

Peters, C.M., Gentry, A.H. and Mendelsohn, R.O. 1989. 'Valuation of Amazonian rainforest'. Nature, 339: pp/ 655-6.

Phuthego, T.C. and Chandra, R. 2004. 'Traditional ecological knowledge and community-based natural resource management: lessons a from a Botswana wildlife management area'. Applied Geography, 24: pp. 57-76.

Portela, R. and Rademacher, I. 2001. 'A dynamic model of patterns of deforestation and their effect on the ability of the Brazilian Amazon to provide ecosystem services'. Ecological Modelling, 143: pp. 115-46.

Pyhälä, A. Brown, K. and Adger, N.W. 2006. 'Implications of livelihood dependence on non-timber products in Peruvian Amazon'. Ecosystems, 9: pp. 1328-41.
Sayer, J. and Campbell, B.M. 2004. The science of sustainable development: local livelihoods and the global environment. Cambirdge University press, Cambridge. 268 pp.

Seidl, A.F. and Moraes, A.S. 2000. 'Global valuation of ecosystem services: application to the Pantanal da Nhecolandia, Brazil'. Ecological Economics, 33: pp. 1-6.

Shackleton, C.M. 1996. 'Potential stimulation of local rural economies by harvesting secondary products: a case study of the central eastern Transvaal lowveld'. Ambio, 25: pp. 33-8.

Shackleton, C.M., Shackleton, S.E., Buiten, E. and Bird, N. 2007. 'The importance of dry forests and woodlands in rural livelihoods and poverty alleviation in South Africa'. Forest Policy \& Economics 9: pp. 558-77.

Shackleton, S.E., Shackleton, C.M., Netshiluvhi, T.R., Geach, B.S., Ballance, A. and Fairbanks, D.H.K. 2002. 'Use patterns and value of savanna resources from three rural villages in South Africa'. Economic Botany, 56: pp. 130-46.

Sheil, D., Liswanti, N., van Heist, M., Basuki, I. Syaefuddin, Samsoedin, I., Rukmiyati, Agung, M. and Sardjono. (2003). 'Local priorities and biodiversity'. Tropical Forest Update 13(1): pp. 16-18.

Sist, P., Sheil, D., Kartawinata, K. and Priyadi, H. 2003. 'Reduced Impact Logging in Indonesian Borneo: some results confirming the needs for new silvicultural prescriptions'. Forest Ecology and Management. 179 (2003): pp. 415-27.

Stoian, D. 2005. 'Making the best of two worlds: rural and peri-urban livelihood options sustained by non-timber forest products from the Bolivian Amazon'. World Development, 33: pp. 1473-90.

van Beukering, P.J.H., Cesar, H.S.J. and Janssen, M.A. 2003. 'Economic valuation of the Leuser National Park on Sumatra, Indonesia'. Ecological Economics, 44: pp. 43-62.

Wunder, S. 2001. 'Poverty alleviation and tropical forest: what scope for synergies?' World Development, 29: pp. 1817-33. 

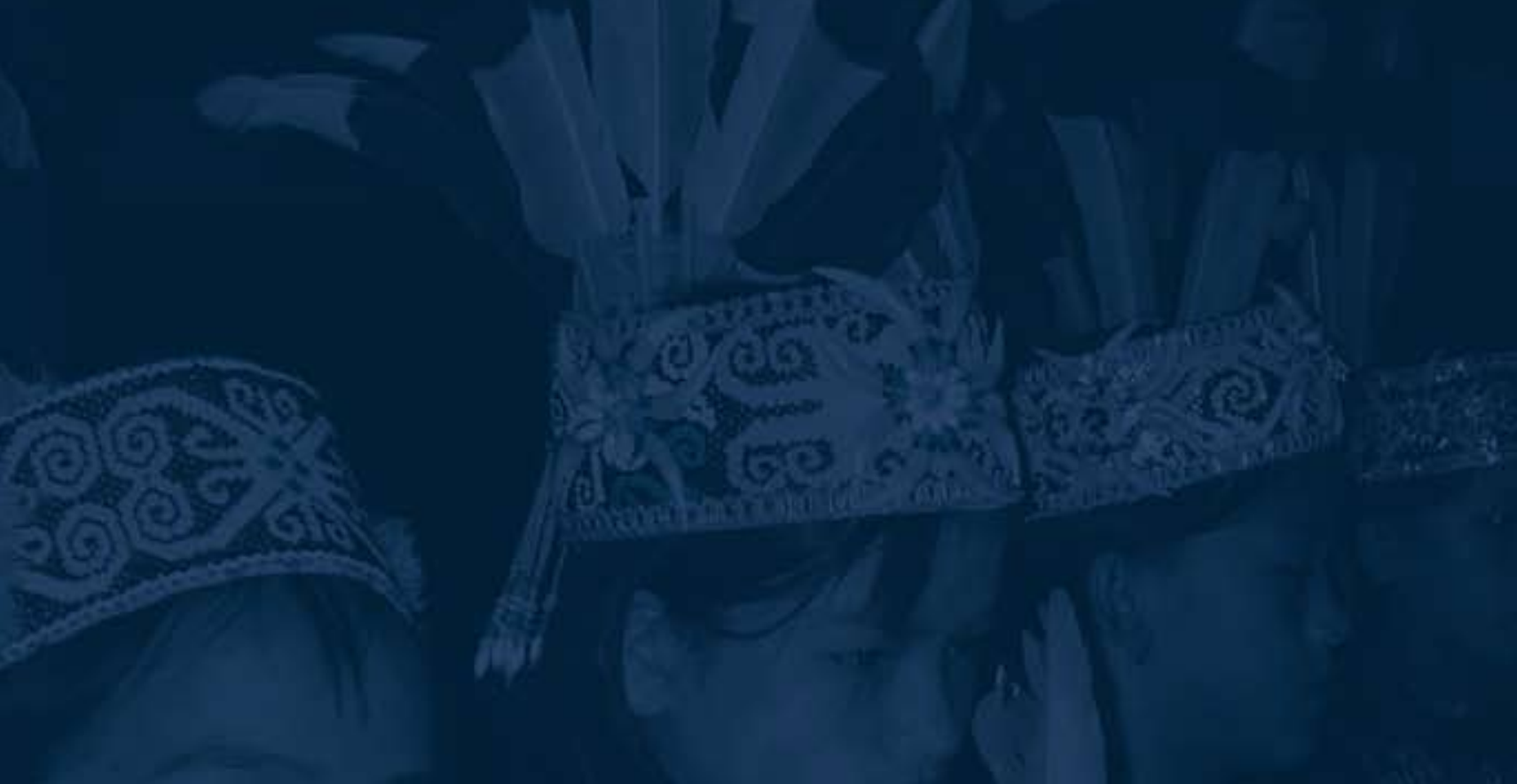

Decentralization has become an important reform process of forest management in many parts of the world. It is unfortunate that in Indonesia, decentralization has been rather abruptly implemented due to the fact that the process of decentralization was parallel with the government reform from highly centralized New Order Government into more democratic decentralized government.

The project "Managing Forest Resources in a Decentralized Environment: Lessons Learnt from the Malinau Research Forest, East Kalimantan, Indonesia" is the technical report of ITTO Project PD 39/00 Rev.3(F) so called Sustainable Collaborative Forest Management: Meeting the Challenges of Decentralization in the Bulungan Model Forest. This book documents the situation just prior to the reform era, the tumultuous reform era, and post reform era. This period is where the processes of forest governance have been somewhat chaotic, but at the same time provide an interesting opportunity for research on the implementation of SFM at the district level of government.

The reports reveals some emerging issues namely: Implementing decentralization policies, securing forest livelihoods, alternative uses for forest resources, intensification of forest use, prompting conservation of forest and resources, forest and health and the role of research in managing forests for livelihoods.

Petrus Gunarso was the project coordinator of ITTO Project PD 39/00 Rev.3(F), a scientist seconded from the Ministry of Forestry to the Center for International Forestry Research (CIFOR) in Bogor, Indonesia. Titiek Setyawati is a Scientist of Forestry Research and Development (FORDA) of the Ministry of Forestry of the Republic of Indonesia. Terry Sunderland is a Scientist at CIFOR, specializing in issues surrounding conservation and development and Charlie Shackleton is a Professor of Environmental Science at Rhodes University in South Africa.
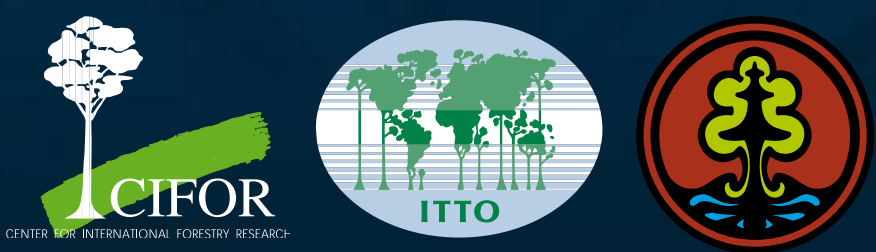

(1)

DFID

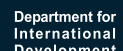

MACARTHUR
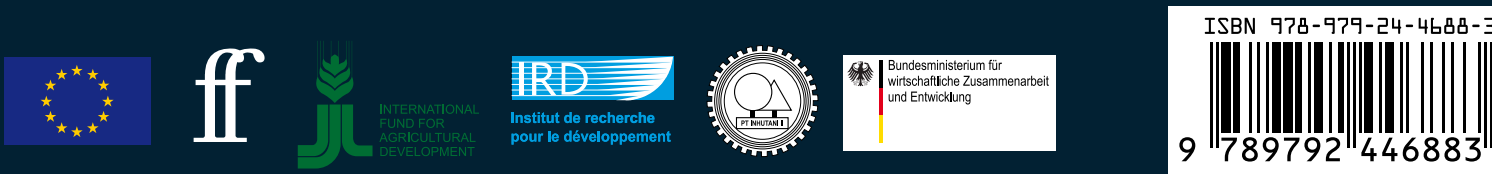